\title{
UPPER PLATE DEFORMATION \\ AND ITS RELATIONSHIP TO THE UNDERLYING \\ HIKURANGI SUBDUCTION INTERFACE - \\ SOUTHERN NORTH ISLAND, NEW ZEALAND
}

BY

DEE NINIS

\begin{abstract}
A thesis
submitted to the Victoria University of Wellington

in fulfilment of the requirements for the degree of

Doctor of Philosophy in Geology
\end{abstract}

Victoria University of Wellington

2018 
At the southern Hikurangi margin, the subduction interface between the Australian and Pacific plates, beneath the southern North Island of New Zealand, is 'locked'. It has previously been estimated that sudden slip on this locked portion of the interface could result in a subduction zone or 'megathrust' earthquake of $\mathrm{M}_{\mathrm{w}}$ 8.0-8.5 or larger. Historically, however, no significant $\left(>M_{w} 7.2\right)$ subduction interface earthquake has occurred at the southern Hikurangi margin, and the hazard from subduction earthquakes to this region, which includes New Zealand's capital city of Wellington, remains largely unknown.

Patterns of uplift at active margins can provide insight into subduction processes, including megathrust earthquakes. With the objectives to i) contribute to the understanding of partitioning of margin-parallel plate motion on to upper plate faults, and ii) provide insight into the relationship of permanent vertical deformation to subduction processes at the southern end of the Hikurangi margin, I investigate flights of late Pleistocene fluvial and marine terraces preserved across the lower North Island. Such geomorphic features, when constrained by numerical dating, provide a valuable set of data with which to quantify tectonic deformation be they locally offset by a fault, or collectively uplifted across the margin.

Fault-offset fluvial terraces along the Hutt River, near Wellington, record dextral slip for the southern part of the Wellington Fault. From re-evaluated fault displacement measurements and new Optically Stimulated Luminescence (OSL) data, I estimate an average slip rate of $6.3 \pm{ }_{1.2}^{1.9} \mathrm{~mm} / \mathrm{yr}(2 \sigma)$ during the last $\sim 100 \mathrm{ka}$. However, slip on the Wellington Fault has not been steady throughout this time. During the Holocene, there was a phase of heightened ground rupture activity between $\sim 8$ and $10 \mathrm{ka}$, a period of relative quiescence between $\sim 4.5$ and $8 \mathrm{ka}$, and another period of heightened activity during the last $\leq 4.5 \mathrm{ka}$. Moreover, these results agree with independent paleoseismological evidence from other sites along the Wellington Fault for the timing of ground rupture events. The time-varying activity observed on the Wellington Fault may be regulated by stress interactions with other nearby upper plate active faults.

Net tectonic uplift of the southern Hikurangi margin is recorded by ancient emergent shore platforms preserved along the south coast of the North Island. I provide a new evaluation of the distribution and age of the Pleistocene marine terraces. Shore platform altitudes are accurately surveyed for the first time using Global Navigational Satellite Systems (GNSS). From these 
data I have determine the shore platform attitudes where they are preserved along the coast. The terraces are also dated, most for the first time, using OSL techniques. The most extensive Pleistocene terraces formed during Marine Isotope Stages (MIS) 5a, 5c, 5e and 7a.

Because the ancient shorelines are now obscured by coverbed deposits, I use shore platform attitudes to reconstruct strandline elevations. These strandline elevations, corrected for sea level during their formative highstands, have been used to quantify rates of uplift across the southern Hikurangi margin.

In the forearc region of the Hikurangi margin, within $\sim 70 \mathrm{~km}$ of the trough, uplift observed on the marine terraces along the Palliser Bay coast monotonically decreases away from the trough. The highest uplift rate of $1.7 \pm 0.1 \mathrm{~mm} / \mathrm{yr}$ is observed at the easternmost preserved terrace, near Cape Palliser, about $40 \mathrm{~km}$ from Hikurangi Trough. Further to the west, at Lake Ferry, uplift is $0.8 \pm 0.1 \mathrm{~mm} / \mathrm{yr}$. The lowest rate of uplift, $0.2 \pm 0.1 \mathrm{~mm} / \mathrm{yr}$, is observed at Wharekauhau, the westernmost marine terrace preserved on the Palliser Bay coast. Overall, the terraces are tilted towards the west, away from the trough, with older terraces exhibiting the most tilting. This long-wavelength pattern of uplift suggests that, in this forearc region of the margin, deep-seated processes, most likely subduction of a buoyant slab in combination with megathrust earthquakes, are the main contributors to permanent vertical deformation.

West of Palliser Bay, at a distance of $>70 \mathrm{~km}$ from the Hikurangi Trough, vertical offsets on the marine terraces are evident across upper plate faults, most notably the Wairarapa and Ohariu Faults. The uplift rate at Baring Head, west and on the upthrown side of the Wairarapa Fault, is as much as $1.6 \pm 0.1 \mathrm{~mm} / \mathrm{yr}$. At Tongue Point, where the Ohariu Fault offsets the marine terraces preserved there, uplift calculated from the western, upthrown side of the fault is $0.6 \pm 0.1 \mathrm{~mm} / \mathrm{yr}$. These uplift rates suggest that, in the Axial Ranges, in addition to sediment underplating, movement on the major active upper plate faults also contributes to rock uplift. 


\section{ACKNOWLEDGEMENTS}

This research would not have been possible without the input of the following people, facilities and organisations, to whom I am grateful.

To my supervisors Tim Little and Nicola Litchfield, for being generous with your time, for your guidance during my research, and for constructive reviews of my written work. Tim, thanks for conceiving the research topic, your many thought-provoking questions, and for your coaching with scientific writing. Nicola, thanks for your help and company out in the field, for our enjoyable scientific discussions, and for your encouragement, especially in the last few weeks of my candidacy.

For funding to undertake this research:

Frank Evison Research Scholarship in Geophysics - special thanks to the family of Frank Evison, and to Euan Smith for his support of my application;

Earthquake Commission - in particular to Hugh Cowan and Priscilla Cheung for their support and encouragement throughout my candidacy;

Impact of Plate Tectonics in and around New Zealand programme (C05X0702) - for the Wellington Fault investigation.

The Luminescence Dating Facility at Victoria University of Wellington, in particular Ningsheng Wang and Uwe Rieser, for Optically Stimulated Luminescence sample preparation and analysis.

To Euan Smith for his conditional probabilities and Bayesian statistical analyses to constrain the ages of the Emerald Hill fluvial terraces.

Greater Wellington Regional Council for providing LiDAR data, and to Andrew Rae of Victoria University of Wellington for his assistance with obtaining and managing this data.

For assistance with (and company during) fieldwork and data collection: Rodney Grapes, Jesse Robins, Robert Langridge, Rachel Carne, Tim Bartholomew, Jim Driscoll, Andrew Mackintosh, Russ Van Dissen, Katie Jacobs, Anya Seward, Jo Leavesley, Jane Chewings, Charles Rands, Nat Carey, Adrian Benson, Mark Henderson, Megan Korchinski, Dan Logan and Liz Schermer and students from Western Washington University. 
The landowners and land managers at Emerald Hill and along the south coast of the North Island, for access to their property and interest in my work - Alex \& Pam Furniss, Donald \& Sally McIlraith, Alastair \& Jacqui Sutherland, Hugh \& Louise Prickett, Wayne Jephson, Guy Parkinson.

For assistance with Matlab: Katie Jacobs.

For additional thoughts and comments on my work:

Dominic Evanzia and Katie Jacobs for comments on my thesis.

Kevin Norton, and two anonymous reviewers whose comments were much appreciated and improved the clarity of the Wellington Fault text (Chapter 2; Ninis et al., 2013).

John Chappell for numerous discussions regarding the marine terrace investigation, in particular on OSL dating and eustatic sea level change.

Dan Zwartz, Eelco Rohling and Andrew Mackintosh for additional sea level advice.

Charles Williams, Susan Ellis, Tim Stern and Huw Horgan for discussions regarding tectonic modelling.

John Begg for discussions regarding the local geology at Turakirae Head.

To friends and colleagues at Victoria University of Wellington:

My office mates, in particular Rachel Carne, Susanne Grigull, Megan Korchinski, Tim Bartholomew, Gemma Wihare, Kyle Clem and Esther van Djik.

Those who offered kind words, support and advice during my journey towards completing my doctorate (somewhat interrupted by having two children) - Katie Jacobs, Shona De Sain, Di Seward, Julie Vry, Ruschle Dadic, Rewi Newnham.

To the geoscientists who taught, mentored, encouraged and inspired me:

My lecturers at La Trobe University, Melbourne - Peter Fleming, Peter 'Jacko' Jackson, Andy Gleadow, Richard Price, John Webb, Chris Gray, and Bob Musgrave.

Colleagues and friends from my time at the Seismology Research Centre, Melbourne - Adam Pascale, Gary Gibson, Wayne Peck, Russell Cuthbertson, Kevin McCue, Trevor Allen, Dan Clark, Paul Sommerville.

Those who encouraged me to undertake a PhD 'across the ditch': Mark Stirling, Hugh Cowan, Euan Smith, Tim Stern, John Townend, Martha Savage.

To my family: Mum and Dad, for your encouragement and all that you continue to do for us, your children. To my sisters Anna and Melina. But most of all to my 'new' family: Andrew, Olive and Leo. 


\section{CONTENTS}

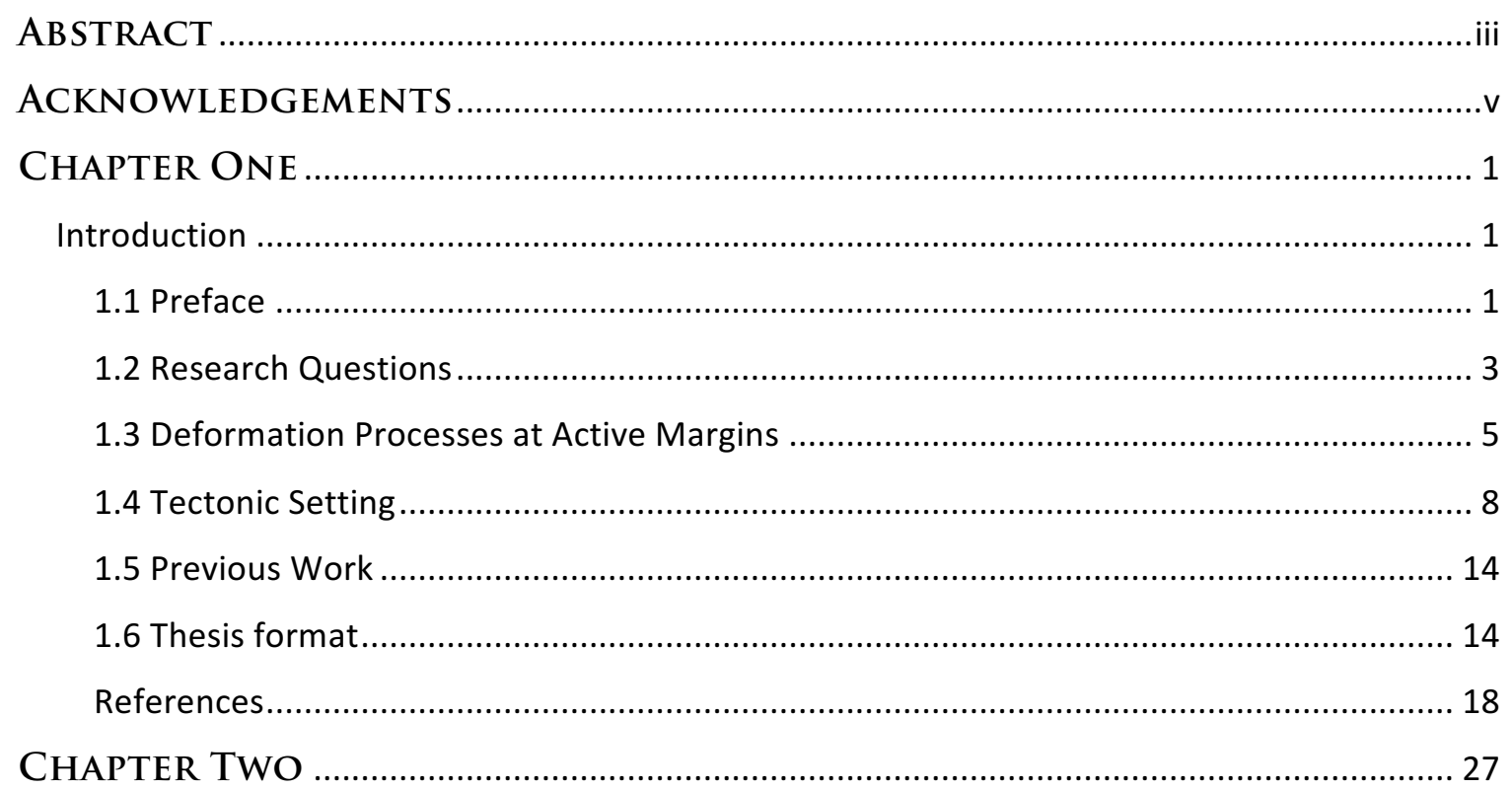

Slip Rate on the Wellington Fault, New Zealand, During the Late Quaternary: Evidence for

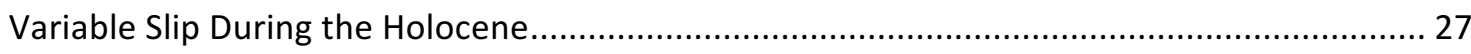

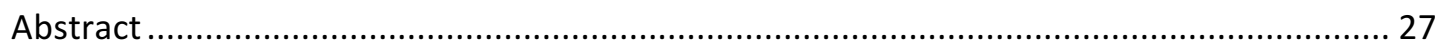

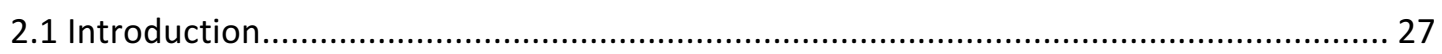

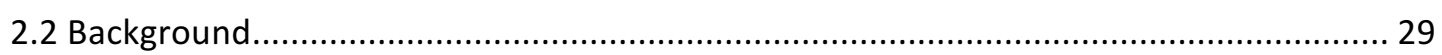

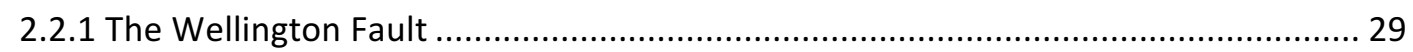

2.2.2 Review of Previous Wellington Fault Slip Estimates............................................... 31

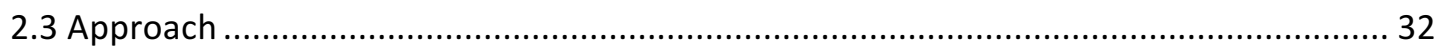

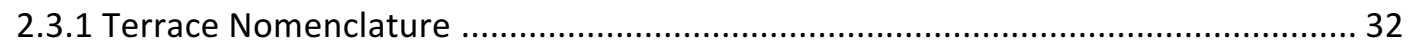

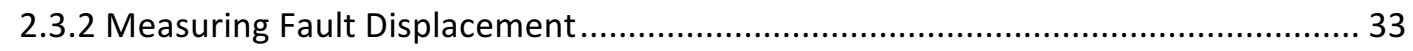

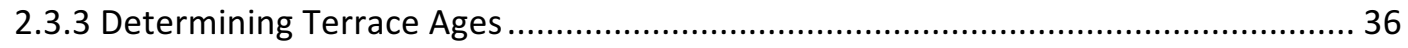

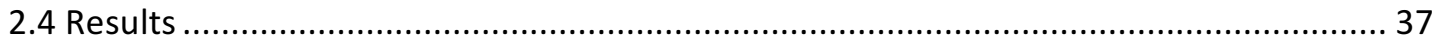

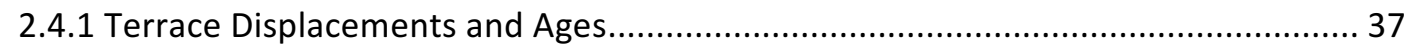

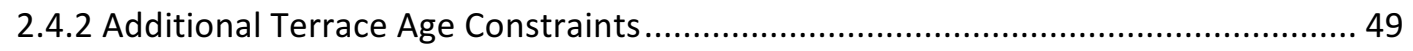

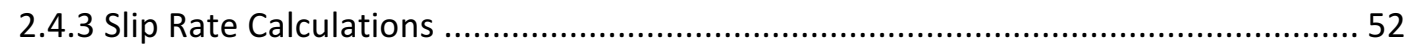

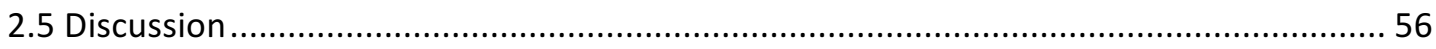

2.5.1 A comparison of Wellington Fault Slip Rate between Emerald Hill and Kaitoke Lakes

2.5.2 The Wellington Fault - a History of Variable Slip? ................................................ 57 
2.5.3 Comparison of Apparent Wellington Fault Temporal Ground Rupture Clustering

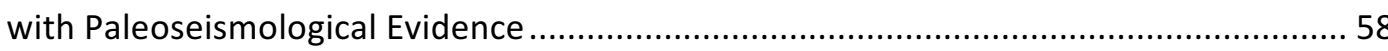

2.5.4 Temporal Variability in Fault Slip - Conduct and Possible Causes ........................... 58

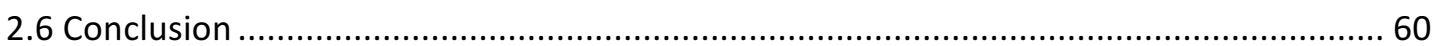

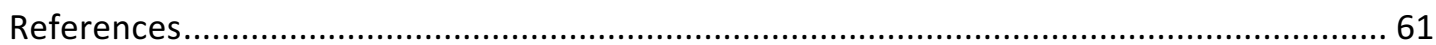

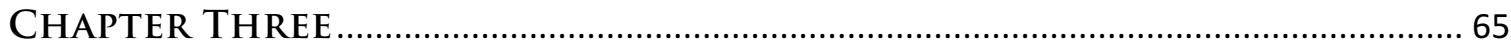

Distribution, Age and Uplift Patterns of Pleistocene Marine Terraces Along the South Coast of

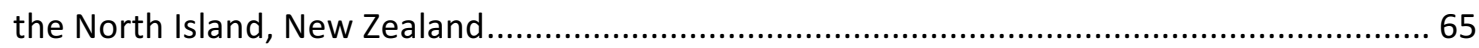

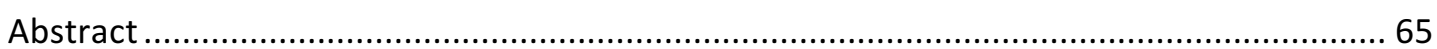

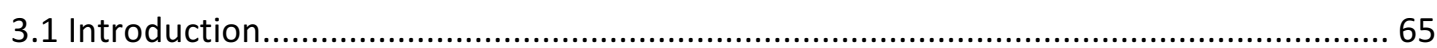

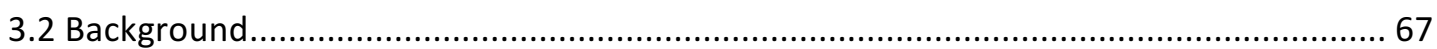

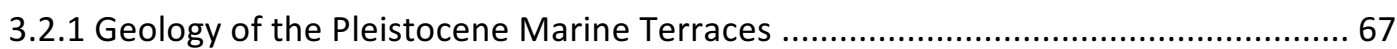

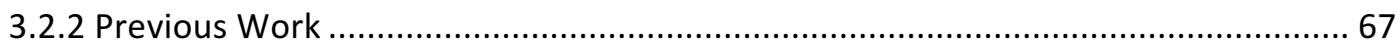

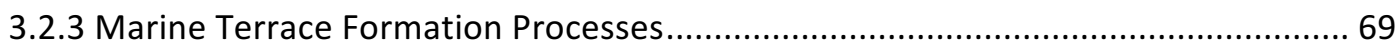

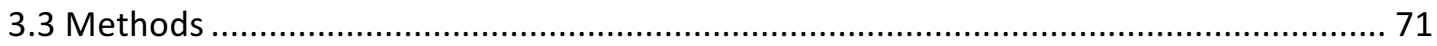

3.3.1 Terrace Distribution, Elevation and Geometry................................................. 71

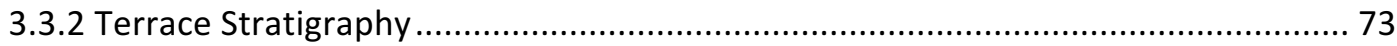

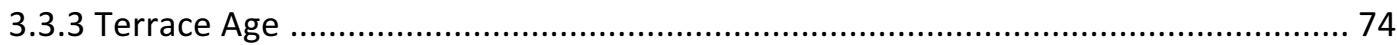

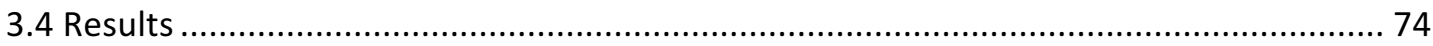

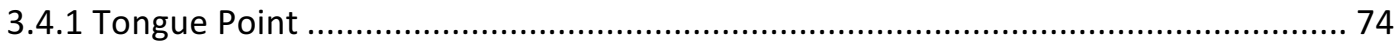

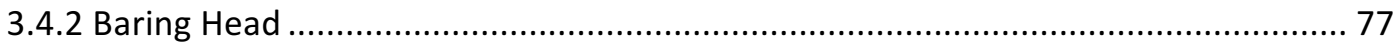

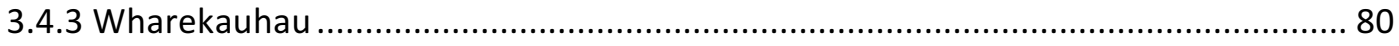

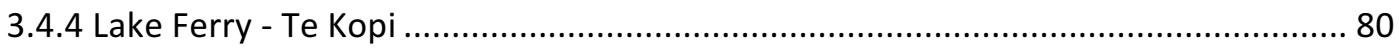

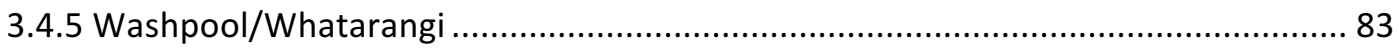

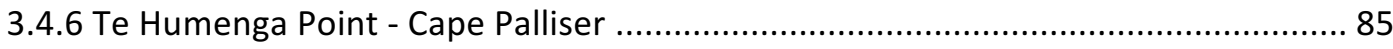

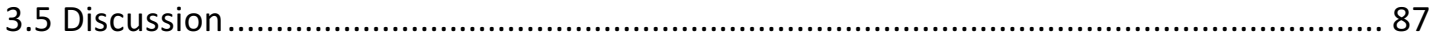

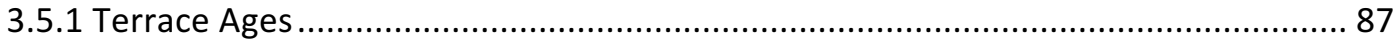

3.5.2 Terrace Correlation and Comparison with Previously Inferred Terrace Ages ........... 89

3.5.3 Terrace Preservation and Deformation ............................................................... 91

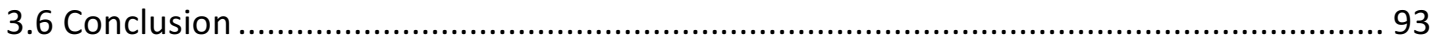

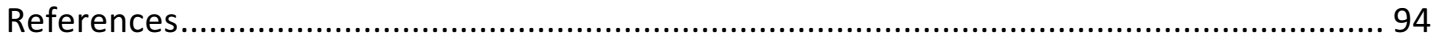

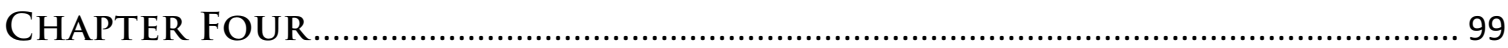

Southern Hikurangi Margin Uplift Rates and Tectonic Implications based on new Marine Terrace Data from the South Coast of the North Island, New Zealand................................... 99

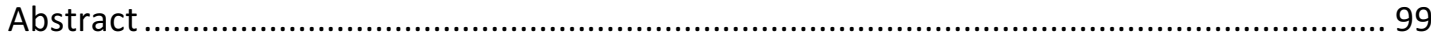

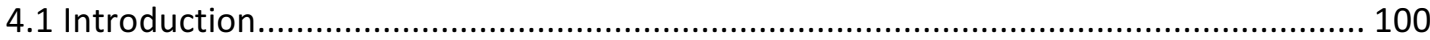




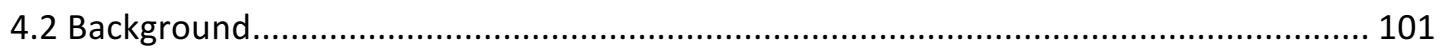

4.2.1 Vertical Deformation Processes at Active Margins .......................................... 101

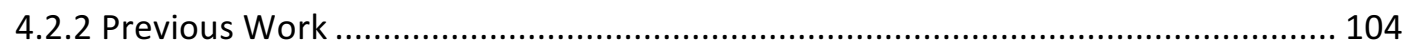

4.2.3 Sea Level Fluctuation Estimates ............................................................ 106

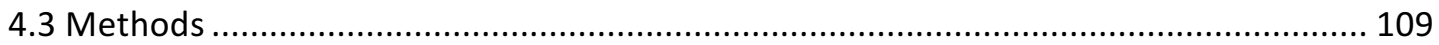

4.3.1 Terrace chronology................................................................................. 109

4.3.2 Strandline elevation calculations....................................................... 110

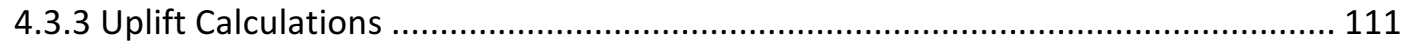

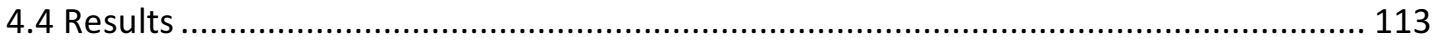

4.4.1 Strandline Elevations \& Uplift Rates....................................................... 113

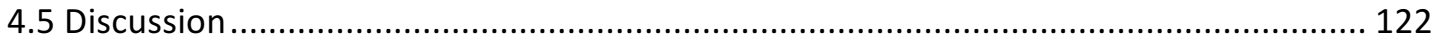

4.5.1 Uplift Rates of the South Coast Terraces .................................................. 122

4.5.2 Uplift Patterns and Implications for Southern Hikurangi Subduction Margin Processes ............................................................................................. 128

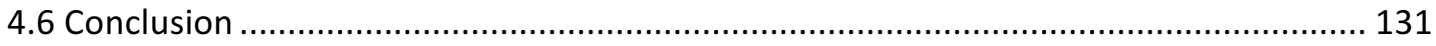

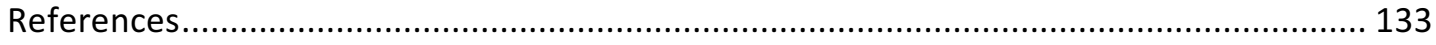

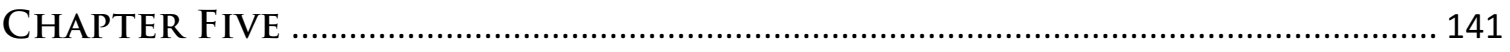

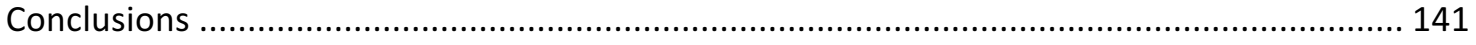

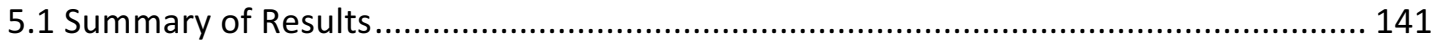

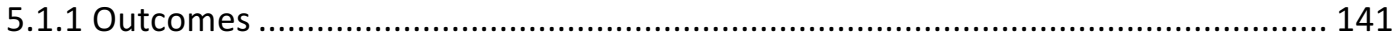

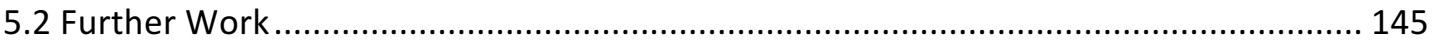

5.2.1 Age of the Baring Head Marine Terraces ................................................. 145

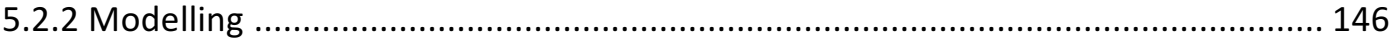

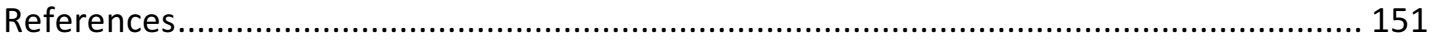

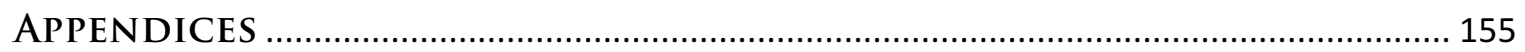

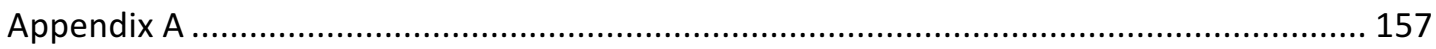

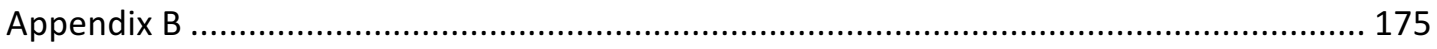

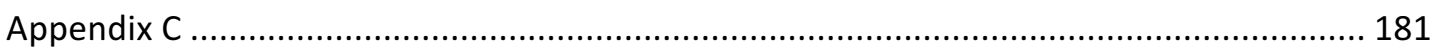

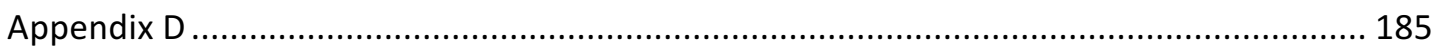

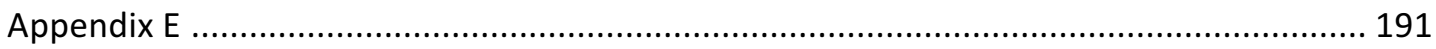




\section{LIST OF FIGURES}

\section{CHAPTER ONE}

Figure 1.1. North Island, New Zealand - Tectonic Setting ............................................... 2

Figure 1.2. Hikurangi subduction margin interface slip rate deficit .................................... 3

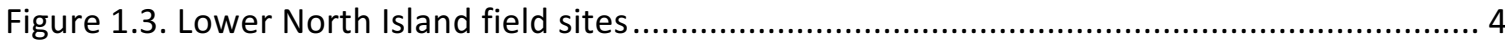

Figure 1.4. Subduction interface rupture coseismic coastal uplift - Hinako Island, Indonesia ...... 5

Figure 1.5. Uplifted marine terraces - Cape Mendocino, California ..................................... 6

Figure 1.6. Southern Hikurangi margin SAHKE subsurface features ...................................... 10

Figure 1.7. Southern Hikurangi margin upper plate faults and subduction interface profile ....... 11

Figure 1.8. Emerald Hill Wellington fault offset fluvial terraces ........................................... 15

Figure 1.9. Ngawi uplifted marine terrace .................................................................. 16

Figure 1.10. Tongue Point uplifted marine terraces ................................................... 17

\section{CHAPTER TWO}

Figure 2.1. Wellington Fault surface trace and field sites - North Island, New Zealand............. 30

Figure 2.2. Geometric features of fault-displaced terrace risers ..................................... 33

Figure 2.3. Digital topographic data of Emerald Hill region ............................................. 35

Figure 2.4. Fault-offset terrace riser projection methods ................................................ 36

Figure 2.5. Map of fault-offset fluvial terraces at Emerald Hill .............................................. 39

Figure 2.6. Detailed topography map of Emerald Hill fault-offset terrace risers .......................40

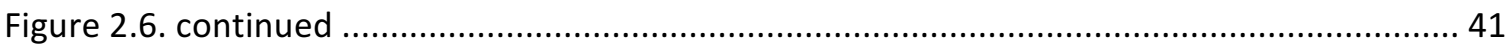

Figure 2.7. Profile of Emerald Hill terrace showing elevations, stratigraphy and OSL ages ........ 45

Figure 2.8. Profiles comparing terrace elevations at Emerald Hill, Te Marua and Brown Owl .... 46

Figure 2.9. Map of fault-offset fluvial terraces at Kaitoke Lakes..................................... 48

Figure 2.10. Detailed map of Kaitoke Lakes fault-offset terrace risers .............................. 48

Figure 2.11. OSL and modelled ages for Emerald Hill terraces ....................................... 51

Figure 2.12. Terrace displacement/age data and Wellington Fault slip rate ............................ 55

\section{CHAPTER THREE}

Figure 3.1. Southern North Island tectonostratigraphic basement geology and field sites......... 68

Figure 3.2. Basic features and corresponding terminology of marine terraces......................... 70 
Figure 3.3. Pleistocene marine terrace and shore platform - Te Humenga, Palliser Bay

Figure 3.4. Tongue Point terrace summary............................................................... 76

Figure 3.5. Baring Head terrace summary ................................................................. 79

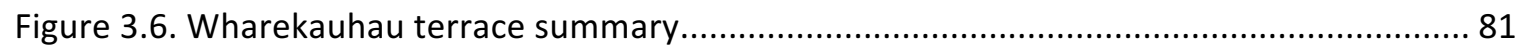

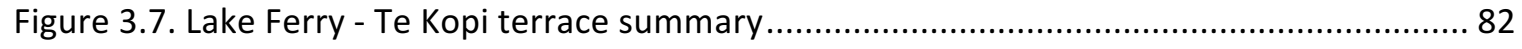

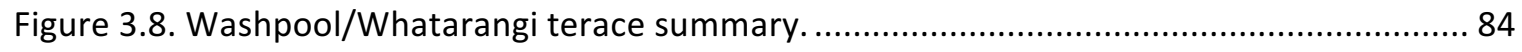

Figure 3.9. Te Humenga Point - Cape Palliser terrace summary. ......................................... 86

Figure 3.10. OSL ages of south coast, North Island marine terraces..................................... 89

Figure 3.11. Terrace elevation profile along the south coast, North Island ............................. 90

\section{CHAPTER FOUR}

Figure 4.1. Distribution of uplifted marine terraces - south coast, North Island..................... 101

Figure 4.2. Marine terrace coseismic uplift patterns ..................................................... 104

Figure 4.3. Upper plate vertical deformation of a southern Hikurangi subduction earthquake. 105

Figure 4.4. Comparison of sea level estimates of different studies ................................... 107

Figure 4.5. Tongue Point strandline elevation profiles ............................................. 115

Figure 4.6. Baring Head strandline elevation profiles ............................................... 117

Figure 4.7. Wharekauhau strandline elevation profiles .............................................. 119

Figure 4.8. Lake Ferry - Te Kopi strandline elevation profiles ..................................... 120

Figure 4.9. Washpool/Whatarangi strandline elevation profiles .................................... 120

Figure 4.10. Te Humenga strandline elevation profiles ...................................................... 122

Figure 4.11. Ngawi (Cape Palliser) strandline elevation profiles ......................................... 123

Figure 4.12. Uplift rates across the southern North Island ............................................ 125

\section{CHAPTER FIVE}

Figure 5.1. Flexure model of thickening subducting crust - setup and results 


\section{CHAPTER ONE}

\section{INTRODUCTION}

\subsection{Preface}

Subduction zone or 'megathrust' earthquakes occur when the locked area along the interface of convergent plates abruptly unlocks and slips. Such seismic events produce the largest and most devastating earthquakes on earth. Examples of subduction interface earthquakes during recent times include the $2011 \mathrm{M}_{\mathrm{w}} 9.1$ Tohoku-Oki earthquake offshore of Japan, the $2004 \mathrm{M}_{\mathrm{w}}$ 9.1 Sumatra-Andaman earthquake, the $1964 \mathrm{M}_{\mathrm{w}} 9.2$ Great Alaska earthquake, and the $\mathrm{M}_{\mathrm{w}} 9.5$ Valdivia, Chile earthquake in 1960 (USGS Earthquake Catalogue https://earthquake.usgs.gov/earthquakes/browse/largest-world.php).

New Zealand is located on the Pacific-Australian plate boundary. Beneath the North Island, the Pacific Plate is undergoing oblique westward subduction under the Australian Plate along the Hikurangi subduction interface (Fig. 1.1). Geodetic data reveal that below the southern end of the North Island the degree of interplate locking is highest (e.g. Walcott, 1984; Reyners, 1998; Darby \& Beavan, 2001; Wallace et al., 2004; 2012) (Fig. 1.2), as is consistent with the generation of subduction interface earthquakes (Stirling et al., 2012). Historically, however, no significant $\left(>M_{w}\right.$ 7.2) subduction earthquake has taken place at the southernmost North Island (Wallace et al., 2009). As a result, the hazard from subduction interface earthquakes in this region, which includes New Zealand's capital city of Wellington, remains largely unknown.

Upper plate deformation patterns at active margins can provide crucial insight into subduction processes, including megathrust earthquakes (e.g. Muhs et al., 1990; Ortlieb et al., 1996; Beanland et al., 1998; Nicol et al., 2002; Pedoja et al., 2006; Litchfield et al., 2007; Saillard et al., 2009; Matsu'ura et al., 2009; Shikakura, 2014). Fortunately, the North Island of New Zealand is remarkable for providing a largely subaerially-exposed forearc accessible to direct geological study, whereas most other subduction margins are completely submerged (e.g. Cascadia Subduction Zone - offshore western North America; Aleutian Trench - offshore south coast of Alaska to southeast of Kamchatka Peninsula; Japan Trench - offshore northeast Japan). The challenge is to distinguish the different causes of permanent tectonic deformation as expressed in the topography. 
Along the northern and central east coast of the North Island, beneath which the subduction interface is only moderately or weakly coupled (e.g. Walcott, 1984; Reyners, 1998; Wallace et al., 2004; 2012) (see Fig. 1.2), upper plate deformation and how it may reflect underlying subduction processes has been the subject of a number of investigations (e.g. Berryman et al., 1989; Ota et al., 1991; Litchfield et al., 2007; Wilson et al., 2007 a, b; Berryman et al., 2011). However, a margin-wide investigation of deformation across the southern North Island has been lacking; much remains unknown regarding how subduction processes, and the presence of the zone of interface locking, may influence upper plate tectonic deformation in this region. The focus of this research, therefore, is on upper plate tectonic deformation of the Hikurangi margin across the southernmost North Island of New Zealand.

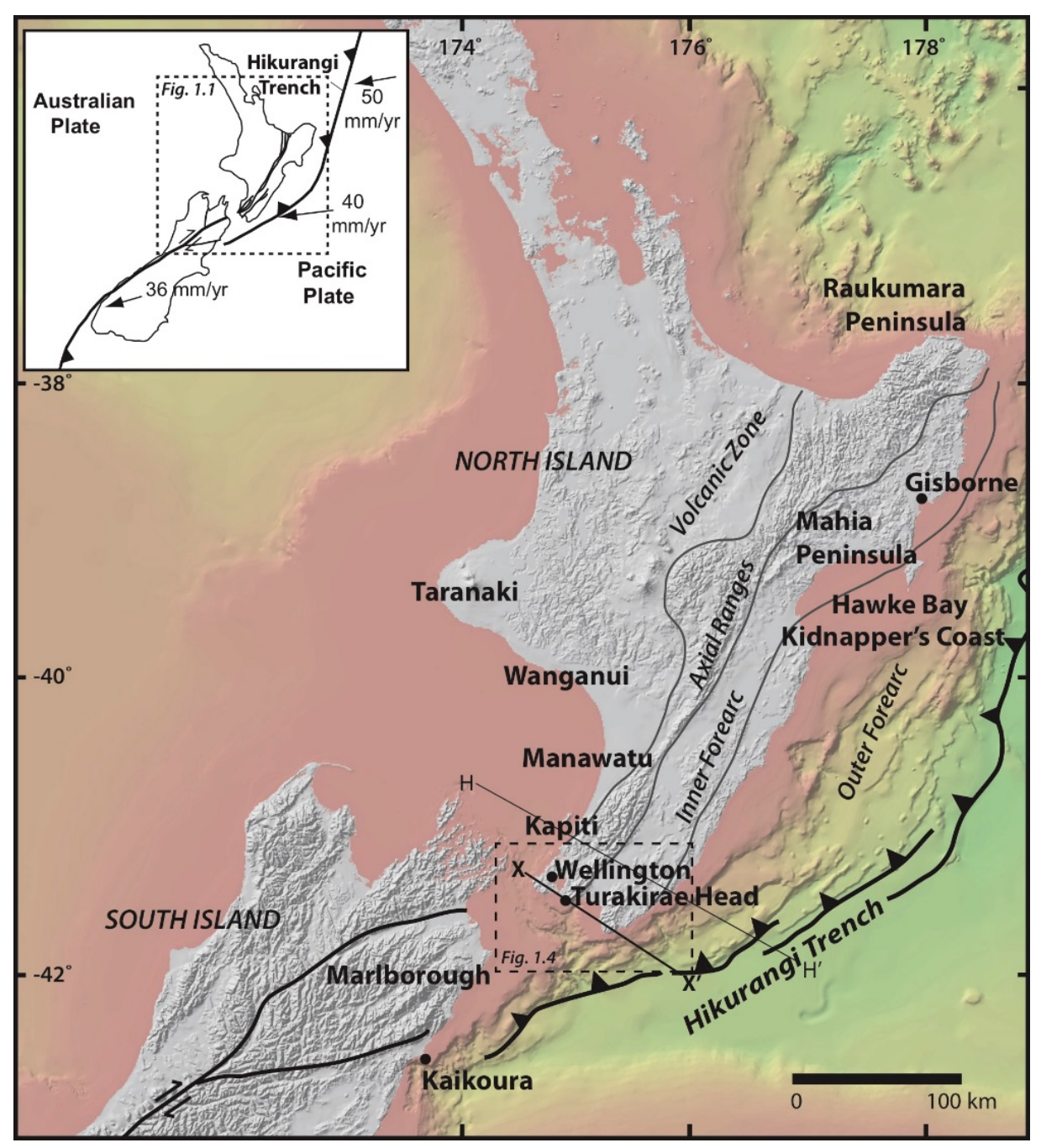

Figure 1.1. North Island of New Zealand showing surface topographic features and offshore bathymetry (from Mitchell et al., 2012) and the major structural elements of the Hikurangi subduction margin. Also shown are place names referred to in the text, location of $\mathrm{H}_{-} \mathrm{H}^{\prime}$ profile of Fig. 1.4 and $\mathrm{X}-\mathrm{X}$ ' profile of Fig. 1.5. Inset - Tectonic setting of New Zealand. 


\subsection{Research Questions}

The objectives of this research are to resolve the following:

1. Do subduction interface earthquakes leave a permanent signal of uplift across the southern Hikurangi margin?

2. What other processes contribute to the creation of permanent topography across this region?

3. Can we contribute to our current understanding of slip partitioning (how relative plate motions are accommodated or distributed across the margin) on upper plate faults across the southern North Island?

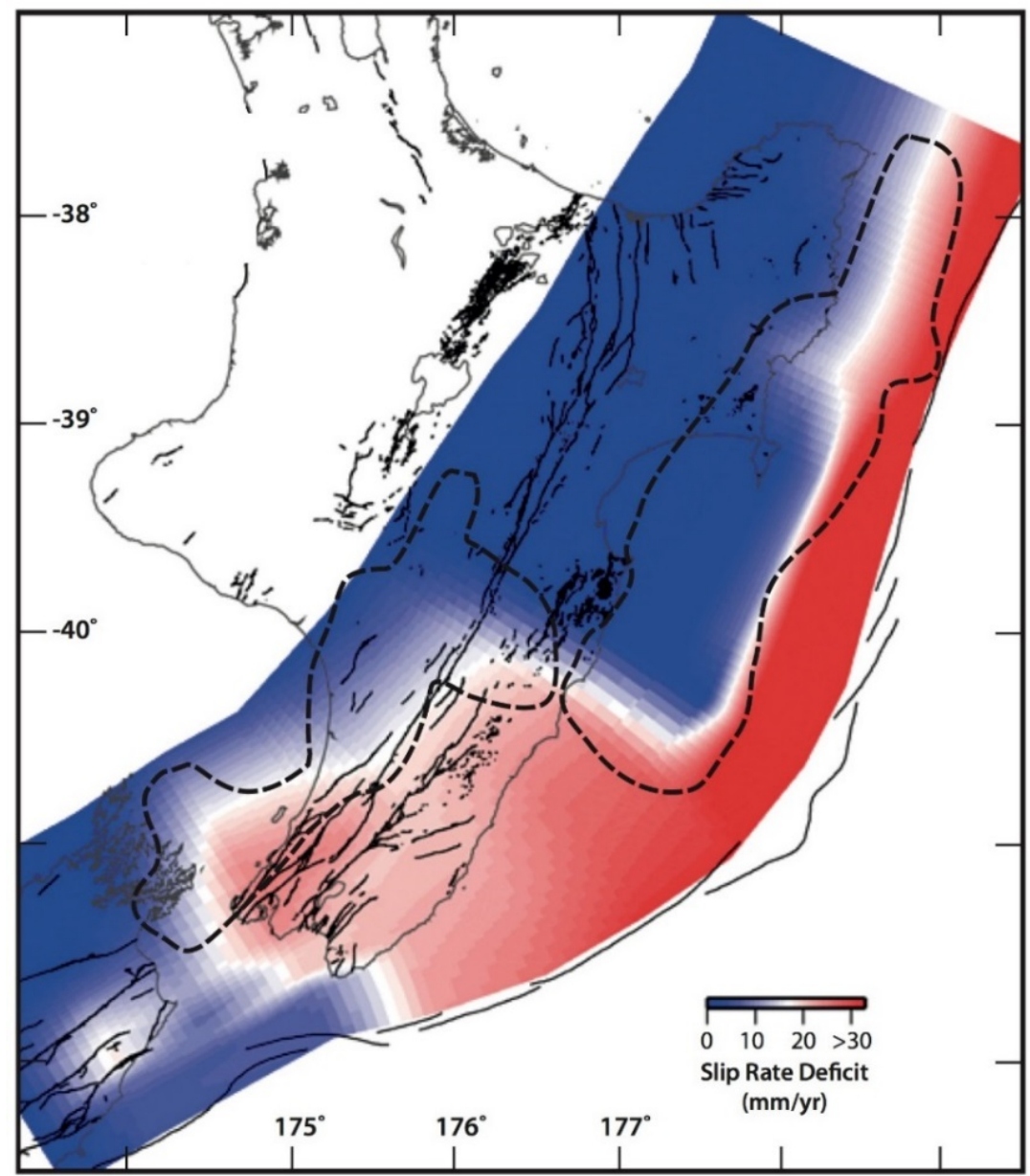

Figure 1.2. Hikurangi subduction interface slip rate deficit; regions in blue are weakly coupled (allowing aseismic slipping), regions in red are fully coupled (locked) (from Wallace et al., 2012), based on a kinematic model incorporating GNSS velocities and active fault slip data. Dashed lines show regions where slow slip events have been recognized (from Wallace \& Beavan, 2010). 
Answering these questions will not only help us to better understand the behaviour of the southern Hikurangi subduction interface, including the hazard posed by megathrust earthquakes, but can also be applied to advancing our understanding of subduction zones worldwide.

I make use of the flights of late Pleistocene ( $\sim 200 \mathrm{ka}$ to $\sim 10 \mathrm{ka})$ fluvial and marine terraces preserved across the lower North Island. These geomorphic features provide a valuable set of data with which to undertake a direct field study of tectonic deformation - be they locally offset by a fault, or collectively uplifted across the margin - as established worldwide, in a number of comparable tectonic deformation studies (e.g. Ghani, 1974, 1978; Bradley \& Griggs, 1976; Merritts \& Bull, 1989; Muhs et al., 1990; Kneupfer, 1992; Grapes, 1993; Berryman, 1993 a, b; Ota et al., 1996; Benedetti et al., 2002; Bennett et al., 2004; Litchfield et al., 2007; Saillard et al., 2009; Matsu'ura et al., 2009; Little et al., 2010). The field sites examined for this investigation, in particular those sites where marine terraces are preserved along the south coast of the North Island, roughly fall on a transect that is orthogonal to the Hikurangi margin (see Profile $\mathrm{X}-\mathrm{X}^{\prime}$ in Fig 1.1, Fig. 1.3), allowing for a margin-normal investigation of tectonic deformation.

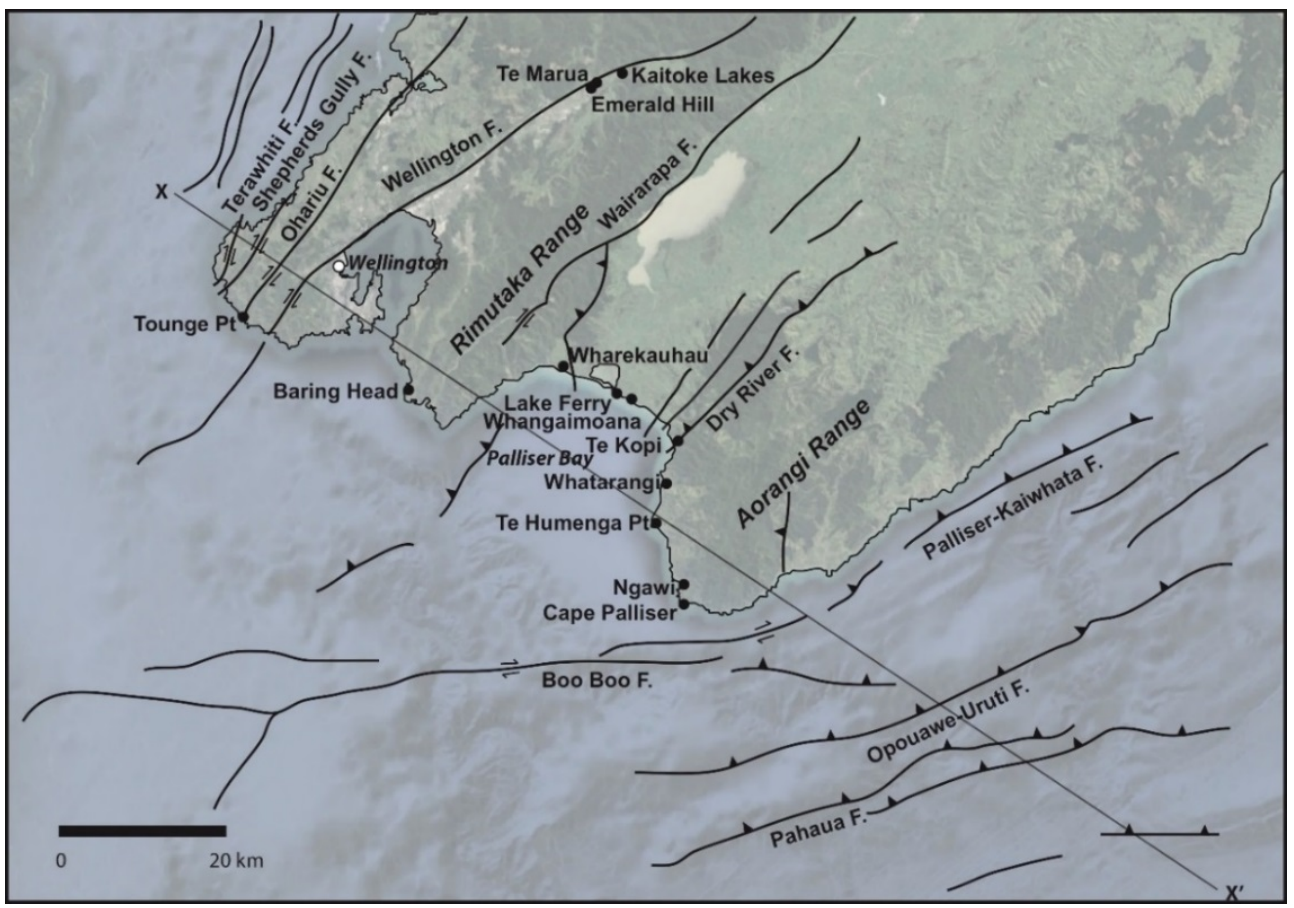

Figure 1.3. Map of the lower North Island, showing the major active faults (Barnes et al., 1998; Barnes \& Audru, 1999; Begg \& Johnston, 2000; GNS Science Active Faults Database - http://data.gns.cri.nz/af/) and field sites of this investigation. Cross section of X-X' profile is shown in Fig. 1.5. Background satellite image from Digital Globe/ TerraMetrics (Google Earth) 2016. 
This study is divided into two parts. The first considers slip on the southern segment of the Wellington Fault, contributing to our understanding of the partitioning of margin-parallel plate motion on to upper plate strike-slip faults. The second part of this study looks into the pattern of coastal uplift across the south coast of the North Island, in an attempt to determine the relationship between permanent vertical deformation and subduction processes at the southern end of the Hikurangi subduction margin.

\subsection{Deformation Processes at Active Margins}

The sudden unlocking along the interface of convergent plates during subduction zone earthquakes results in dramatic coseismic changes to local coastlines. Coseismic deformation reported immediately after the $2011 \mathrm{M}_{\mathrm{w}} 9.1$ Tohoku-Oki earthquake, the $2004 \mathrm{M}_{\mathrm{w}} 9.3$ SumatraAndaman earthquake, the $1964 \mathrm{M}_{\mathrm{w}} 9.4$ in Alaska, the $1960 \mathrm{M}_{\mathrm{w}} 9.5$ Chile earthquake, and other subduction interface earthquakes, generally includes the abrupt uplift of the coast closest to the subduction trench (Fig. 1.4), often resulting in a tsunami. Coseismic uplift from past subduction interface earthquakes has been observed up to $\sim 150 \mathrm{~km}$ from the trench over areas $\sim 1000 \mathrm{~km}$ or greater in length. In addition, a similarly-oriented region of subsidence appears further from the trench, between distances of $\sim 150-250 \mathrm{~km}$ (e.g. Grantz et al., 1964; Plafker, 1965; 1972; Subarya et al., 2006; Briggs et al., 2006; Vigny et al., 2011).

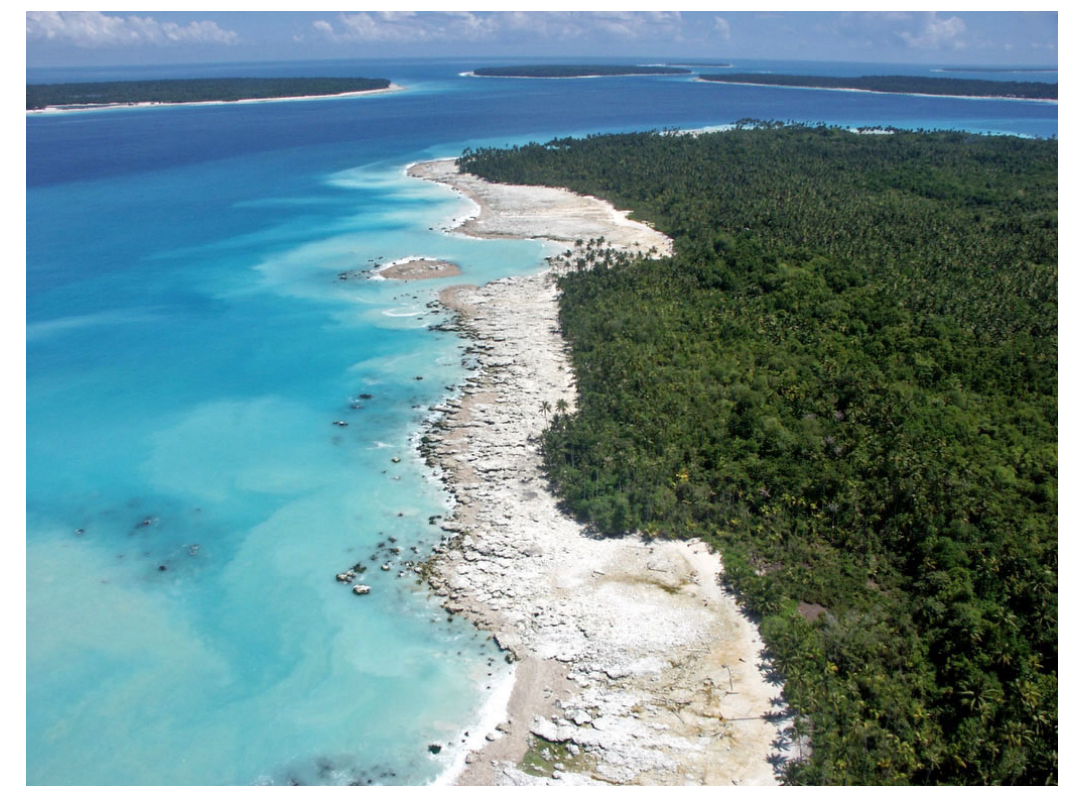

Figure 1.4. Coseismic coastal uplift along the Hinako islands, west of Nias, Indonesia, resulting from the $\mathrm{M}_{\mathrm{w}}$ 8.7 Nias-Simeulue earthquake in March, 2005. Prior to the earthquake, the sea reached almost to the trees. This island, located $\sim 60 \mathrm{~km}$ from the Sunda trench, was uplifted by about $2 \mathrm{~m}$ (Konca et al., 2007). Photo taken by A. Meltzner, used with permission. 
Coseismic vertical deformation at subduction zones is a result of the release of strain accumulated between earthquakes (e.g. Savage, 1983). Following a subduction interface earthquake, post-seismic relaxation is followed by interseismic elastic strain accumulation which generally results in subtle, ongoing movement, often in the opposite direction to coseismic deformation (subsidence in the zone of co-seismic uplift and vice versa). These interseismic processes commonly recover the coseismic deformation in the decades following the earthquake, as was reported after the $\mathrm{M}_{\mathrm{w}} 7.7$ Nicoya Peninsula, Costa Rica earthquake (e.g. Marshall \& Anderson, 1995); there, locals recounted the shoreline dropping in elevation at the time of the earthquake, only to return to its former elevation forty years later. This process of stress accumulation and release, repeated, is known as the seismic cycle (Reid, 1910).

Simple elastic dislocation models of strain accumulation and release at convergent plate boundaries, such as that by Savage (1983), anticipate little inelastic, or permanent, deformation over periods greater than several earthquake cycles. However, some convergent margins exhibit evidence for permanent vertical deformation, as apparent in uplifted ancient shorelines preserved along nearby coasts. For example, each of the Holocene terraces preserved at Cape Mendocino, California, are inferred to be a result of rupture on the Cascadia megathrust (Fig. 1.5) (e.g. Merritts \& Bull, 1989; Carver et al., 1994; Murray et al., 1996; Merritts, 1996). Similarly, many of the raised shorelines of Isla Mocha, south-central Chile are also likely the result of nearby subduction interface earthquakes (e.g. Nelson \& Manley, 1992). As such, alternative models for convergent plate boundaries, in which permanent deformation accrues, have also been developed (e.g. Matsu’ura \& Sato, 1989; Sato \& Matsu'ura, 1993).

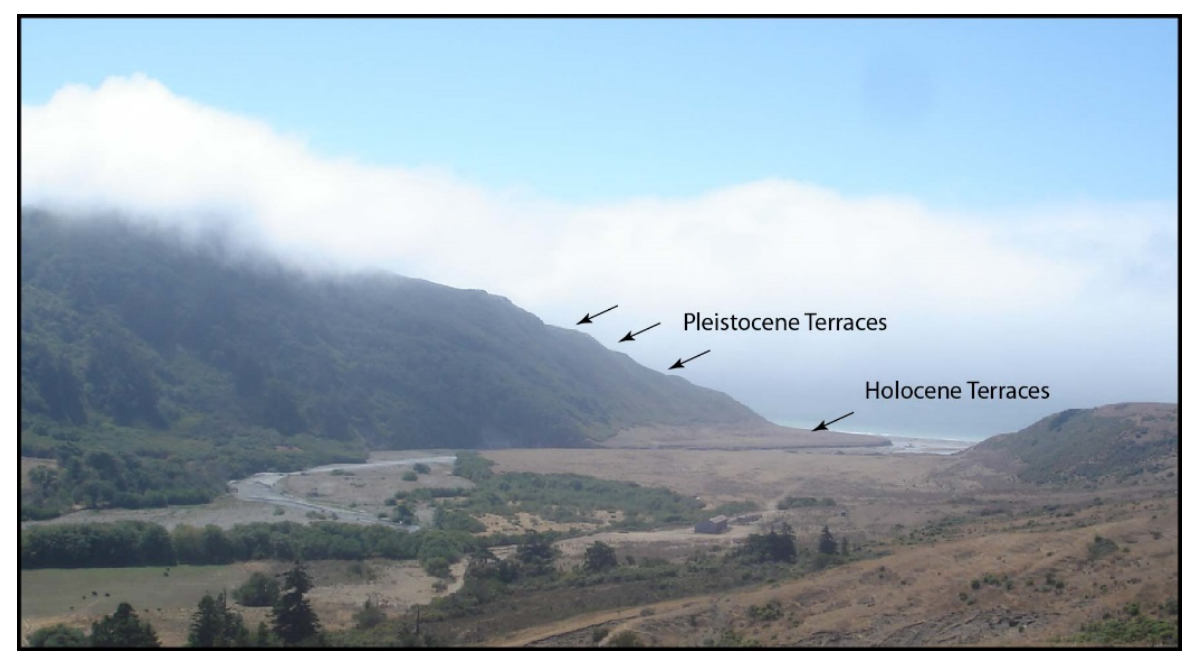

Figure 1.5. Uplifted marine terraces, Bear River, near Cape Mendocino, California. Photo sourced from Thewellman - Own work, CC0, https://commons.wikimedia.org/w/index.php?curid=34458317. 
Permanent coastal vertical deformation at subduction margins has been attributed to a number of different, often site-specific, processes. Over longer periods of time (i.e. 100,000's of years), deep-seated processes such as the characteristics of the subducting plate, for instance crustal thickness and variations in topography, can influence rates and patterns of deformation on the upper plate. For example, at Cape Mendocino, uplift for the last $2330 \mathrm{ka}$ has been explained by the growth of a slab window south of the Mendocino Triple Junction (e.g. Merritts \& Bull, 1989). Along the coast of southern Peru, uplift rates have increased since $\sim 800$ ka due to the Nazca Ridge subduction (Saillard et al., 2011).

Marine terraces preserved at Nankaido (e.g. Fitch \& Scholz, 1971) were originally thought to be coseismic, and a result of near-surface steepening of the main plate boundary, resulting in localised strain release which exceeds the interseismic strain accumulation (Yonekura \& Shimazaki, 1980). More recently, however, the development of the Nankaido terraces has been attributed to offshore, upper-plate faulting (Matsu'ura, 2015). Indeed, strain released during earthquake ruptures of upper plate faults can also produce coastal uplift. One local example is the $1855 \mathrm{M}_{\mathrm{w}} 8.2$ Wairarapa Fault earthquake, which uplifted the coast $\sim 10 \mathrm{~km}$ to the west of the fault, at Turakirae Head, by up to $6.4 \mathrm{~m}$ (McSaveney et al., 2006). Moreover, repeated rupture on the Wairarapa Fault has resulted in several instances of coseismic uplift at Turakirae Head, as evident in a stepped series of four elevated beach ridges ( $\sim 24$ m cumulative since $\sim 6.7$ ka) (McSaveney et al., 2006). The $\mathrm{M}_{\mathrm{w}} 7.8$ Hawke's Bay earthquake of 1931 reportedly caused coseismic deformation which resulted in coastal uplift around Napier by up to $2.7 \mathrm{~m}$ over an area $\sim 120 \mathrm{~km}$ long and $\sim 20 \mathrm{~km}$ wide (e.g. Walcott, 1978; Hull, 1990). At Kaikoura Peninsula, on the east coast of the South Island, a preserved suite of five Pleistocene-aged terraces, as well as younger Holocene terraces, have been inferred to be the result of movement on a nearby offshore fault, south east of the peninsula (Ota et al., 1996; Gardner, 2011). During the $\mathrm{M}_{\mathrm{w}} 7.8$ Kaikoura earthquake in November, 2016, the local coastline was again uplifted, by up to $6.5 \mathrm{~m}$ (Hamling et al., 2017; Clark et al., 2017). Because upper plate faults tend to be more steeply dipping and cover a smaller area, coseismic deformation resulting from movement on these structures is more localised, typically within a few 10's of km from the fault.

In summary, a number of processes, both seismic and aseismic, deep-seated and upper-plate structure-related, contribute to tectonic deformation at active margins. As such, over many earthquake cycles $(100,000$ 's of years) net tectonic deformation does not necessarily reflect deformation purely from subduction interface earthquakes, if at all. However, we may expect that deformation reflecting subduction-related processes would more typically be expressed as broad-wavelength (100's of km) signatures, for instance as observed with the 1964 Alaska 
earthquake (Grantz et al., 1964; Plafker, 1965; 1972) and the 2004 Sumatra-Andaman earthquake (Subarya et al., 2006). Moreover, if coseismic uplift is not completely elastic and recoverable, then evidence of multiple subduction interface earthquakes could be preserved as a stepped pattern in the coastal topography, with each step being a former shore platform uplifted coseismically, such as the terraces preserved at Cape Mendocino, California (e.g. Merritts \& Bull, 1989; Carver et al., 1994; Murray et al., 1996; Merritts, 1996). Although multiple rupture events on an upper plate fault could also be expressed as a stepped pattern in the coastal topography, we can differentiate between the two processes based on the difference in wavelength, remembering that subduction interface events result in a larger, longerwavelength region of deformation, while upper plate structures produce localised, shorter wavelength patterns of deformation.

\subsection{Tectonic Setting}

The Hikurangi subduction thrust can be traced as a surface expression offshore of the northeast of the North Island, to its southernmost extent at the northernmost South Island (see Fig. 1.1). Along this interface, the oceanic Pacific Plate subducts westward beneath the continental crust of the Australian Plate, a process which began $\sim 23$ Ma ago (e.g. Kamp, 1999). During at least the last 1-2 Ma, subduction has included that of the Hikurangi Plateau, a thick and buoyant igneous province (e.g. Davy \& Wood, 1994; Nicol et al., 2002; Reyners et al., 2006; Wallace et al., 2009). Convergence rates vary along the margin; at the northeastern North Island rates are $\sim 45 \mathrm{~mm} / \mathrm{yr}$, while at the southernmost North Island the Pacific Plate moves at $\sim 40 \mathrm{~mm} / \mathrm{yr}$ towards $\sim 260^{\circ}$ (DeMets et al., 1990; 1994; 2010; Wallace et al., 2007) (see Fig 1.1 Inset). A subtle change in plate convergence direction, in combination with the change in orientation of the plate boundary, results in greater obliquity in plate convergence towards the south, such that in the South Island of New Zealand the two plates collide through oblique continental transpression.

Geophysical studies (e.g. gravity and magnetic modelling (e.g. Davy \& Wood, 1994); seismic reflection imaging (e.g. Barnes et al., 1998; Barker et al., 2009; Barnes \& Audru, 1999; Bassett et al., 2010; Mountjoy \& Barnes, 2011; Henrys et al., 2013) seismic tomography (e.g. Reyners et al., 2006)) have revealed details of the offshore structure of the Hikurangi margin, and have allowed sub-surface imaging of the geometry of the interface and structures within the overriding plate and subducting slab. In addition, geodetic studies (Wallace et al., 2004; 2007; 2012) have uncovered evidence regarding the seismogenic behaviour of the subduction 
interface. These studies have revealed a number of along-strike variations within the Hikurangi margin, which are summarised below.

At latitudes of the northern Hikurangi margin $\left(\sim 37.5^{\circ}\right.$ to $\left.39^{\circ} \mathrm{S}\right)$ the subduction trench is located $\sim 60-80 \mathrm{~km}$ from the east coast of the North Island of New Zealand. This offshore region of the forearc is narrow and steep, with local relief reflecting underlying subducted seamounts (Barker et al., 2009); seamounts being a typical feature of the Pacific Plate at these latitudes (Davy \& Wood, 1994). Across this region, the subducting crust is about $\sim 10 \mathrm{~km}$ thick and is within $\sim 15$ $\mathrm{km}$ of the surface. A region of sediment underplating has been identified at the plate interface beneath Raukumara Peninsula (Bassett et al., 2010), where the slab dips at $>12^{\circ}$. The dip of the interface is shallower further south, at $>8^{\circ}$ near Mahia Peninsula, and reaches a depth of 100 $\mathrm{km}$ beneath the Taupo Volcanic Zone (Barker et al., 2009; Williams et al., 2013). In comparison, across the central Hikurangi margin $\left(\sim 39^{\circ}\right.$ to $\left.41^{\circ} \mathrm{S}\right)$, the Pacific Plate crust is $\sim 10$ $12 \mathrm{~km}$ thick and, due to the absence of seamounts, has a smoother topography. Here, the subduction interface has a much shallower dip of $3.5^{\circ}-8^{\circ}$ (Barker et al., 2009; Williams et al., 2013). At these latitudes, the trench-coast distance is $\sim 100-140 \mathrm{~km}$, and is occupied by a wide accretionary wedge. The offshore faults in this region account for $\sim 15 \%$ of plate convergence rates across the central North Island, and fault slip rates correlate well with reported Holocene coastal uplift rates at the nearby Kidnappers Coast, Mahia Peninsula, and Pakarae River (Mountjoy \& Barnes, 2011).

Modelling based on geodetic data (Wallace et al., 2004; 2007; 2012) has shown that subduction interface coupling at the northern and central Hikurangi margin is located at shallow interface depths of $<15 \mathrm{~km}$ from the surface; this corresponds to the region offshore of the east coast of the North Island. This locked zone of the interface has ruptured in recent times, producing two earthquakes in 1947 with magnitudes $M_{w}$ 7.0-7.1 (Poverty Bay) and $M_{w}$ 6.9-7.1 (Tokomaru Bay) (Doser \& Webb, 2003). In contrast, beneath the onshore region, the subduction interface is weakly coupled and strain is released through aseismic slow slip events lasting from several days to over a year (Wallace et al., 2009; Wallace \& Beavan, 2010, Wallace et al., 2012) (see Fig. 1.2).

Results from the 2009-2011 Seismic Array Hikurangi Experiment (SAHKE) (e.g. Henrys et al., 2013; Williams et al., 2013), undertaken along a transect across the southern Hikurangi margin (Fig. 1.6), have added to our comprehension of the relationship between upper plate structures and the seismogenic zone of the subduction interface beneath this region. Results show that across the southern Hikurangi margin ( $\sim 41^{\circ}$ latitude), the subduction interface has a dip of $<5^{\circ}$ at shallow depths (within $\sim 15 \mathrm{~km}$ of the surface) after which there is a sudden change 
in dip to $>15^{\circ}$ at greater depths (see Fig. 1.6). This kink in the interface occurs beneath the Tararua Ranges and coincides with a region of sediment underplating and the juncture where the upper plate Wairarapa Fault intersects the plate interface. In addition, this is also the zone where the seismogenic behaviour of the subduction interface changes, from weakly coupled to strongly coupled (Walcott, 1984; Henrys et al., 2013).

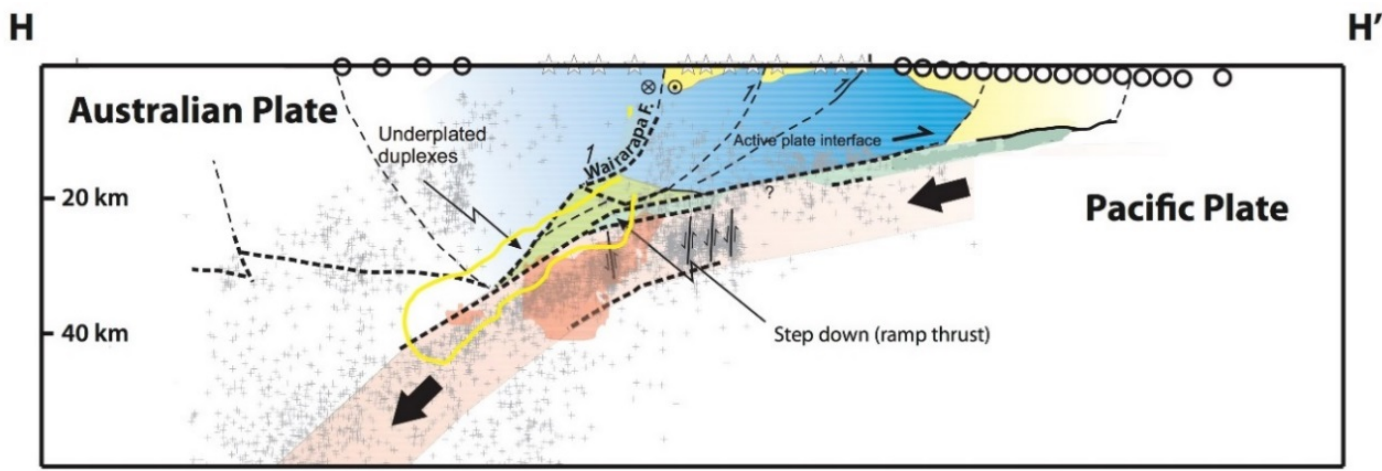

Figure 1.6. Cross section $\mathrm{H}-\mathrm{H}^{\prime}$ across the southern North Island, showing subsurface features of the Hikurangi margin, as interpreted from seismic reflection data collected as part of the SAHKE investigation. Figure taken from Henrys et al. (2013). Stars represent shot point localities, circles show ocean bottom seismometer locations. See Fig. 1.1 for location of profile.

Offshore, the Hikurangi trough veers closer to the coast such that adjacent to the southernmost North Island $\left(\sim 42^{\circ} \mathrm{S}\right)$ the trench-coast distance is only $\sim 40 \mathrm{~km}$. Here, the offshore region consist of a steep accretionary wedge dissected by strike-slip and reverse faults (Barnes \& Mercier de Lepinay, 1997; Barnes et al., 1998; Barnes \& Audru, 1999). Beneath the southern extent of the North Island, the crust dips more steeply at $\sim 15^{\circ}$ (Ansell \& Bannister, 1996; Williams et al., 2013; Henrys et al., 2013) and thickens from west to east, such that it is $\sim 10 \mathrm{~km}$ thick beneath the west coast of the lower North Island, and $\sim 13$ in thickness where it begins its decent at the Hikurangi Trough (Bourne \& Stuart, 2000; Reyners et al., 2011; P. Herath \& T. Stern, pers. comm., 2017). Across this region, the subduction interface is elastically almost 'fully coupled' or 'locked' to a depth of $\sim 40 \mathrm{~km}$, with a coupling coefficient of $\varphi_{\text {ic }}=0.8-1.0$ (e.g., Walcott, 1984; Reyners, 1998; Darby \& Beavan, 2001; Wallace et al., 2004; 2007; 2012) (see Fig. 1.2).

Onshore, evidence of contractional deformation resulting from plate convergence is expressed across the North Island, predominately within and east of the Axial Ranges, in the form of folding, faulting and uplifted landforms. Across the southern North Island, mountainous areas such as the Rimutaka and Aorangi Ranges trend north-east, near parallel to the Hikurangi Trough. In addition, a number of similarly-oriented mostly contractional active faults cross the region. These predominately dextral strike-slip faults are collectively termed the North Island 
Dextral Fault Belt (NIDFB) (Beanland, 1995; Van Dissen \& Berryman, 1996) and include the Wairarapa, Wellington, Ohariu, and Shepherds Gully/Pukerua faults. Major offshore faults include the Palliser-Kaiwhata Fault, the Opouawe-Uruti and Pahaua thrust faults, and the BooBoo Fault (Barnes \& Mercier de Lepinay, 1997; Barnes et al., 1998; Barnes \& Audru, 1999) (see Fig. 1.3, Fig. 1.7).

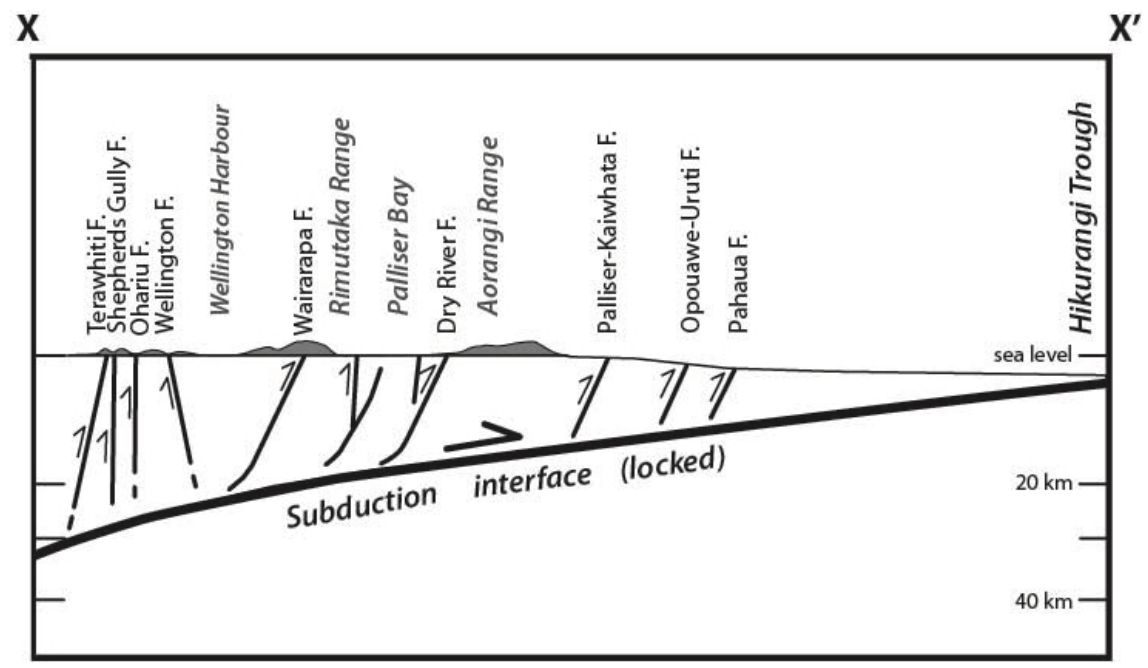

Figure 1.7. Schematic cross section $X-X^{\prime}$ across southern North Island, showing the location of major upper plate faults and depth to the subduction interface. Figure modified after Little et al. (2009) and updated using data from Begg \& Johnston (2000), Henrys et al. (2013) and Williams et al. (2013). See Fig. 1.1, Fig. 1.3 for location of profile.

Onshore strain rate observations, and modelling based on these, have shown that the majority $(>50->70 \%)$ of margin-parallel plate convergence motion is taken up by movement on upperplate faults that occur in the Axial Ranges and exposed forearc region of the Hikurangi margin, as well as vertical axis rotations of the forearc (Nicol \& Beavan, 2003; Nicol \& Wallace 2007; Nicol et al., 2007). An example of margin-parallel motion being accommodated by movement of upper plate faults transpired during the $1855 \mathrm{M}_{\mathrm{w}} 8.2$ Wairarapa Fault earthquake, with as much as $18.7 \mathrm{~m}$ of dextral slip observed at the surface (Rodgers \& Little, 2006). Across the southern Hikurangi margin, most ( $80 \%)$ of margin-perpendicular motion is inferred to be accommodated by slip on the subduction interface and connected imbricate thrusts of the offshore accretionary wedge (e.g. Barnes \& Mercier de Lepinay, 1997; Barnes et al., 1998; Darby \& Beavan, 2001; Nicol \& Beavan, 2003, Wallace et al., 2004; Nicol et al., 2007).

Previous investigations of fluvial and marine terraces in the north-eastern and central North Island, namely their distribution, age, coverbed stratigraphy, and rates and patterns of deformation, have been used to infer subduction processes underlying these areas. Uplift rates 
calculated by Wilson et al. (2007 a, b) from marine terraces preserved along the northeast coast near Raukumara Peninsula are in the range of 1-2 mm/yr for the Holocene. Analysis of the paleoecology and stratigraphy of their overlying coverbeds shows no evidence for abrupt uplift during this time; instead, it is considered that this region experiences gradual, aseismic uplift. This accords with geodetic data which shows that beneath this region the subduction interface is slowly slipping (Walcott, 1984; Wallace et al., 2004; 2012).

North of Gisborne, a sequence of Holocene marine terraces preserved at the mouth of the Pakarae River, and along the coast north of there, records an uplift rate of $\sim 3-5 \mathrm{~mm} / \mathrm{yr}$, increasing to the north (Wilson et al., 2006; Litchfield et al., 2016). The stepped topography of these terraces suggest coseismic uplift, likely due to rupture on an upper-plate, offshore fault (Ota et al., 1991; Wilson et al., 2006; Litchfield et al., 2016); offshore mapping has identified this structure to be the Gable End Fault (Mountjoy \& Barnes, 2011). Litchfield et al. (2010) extended the study area of this region to include uplift inland from the coast, measured from fluvial terraces preserved along the Pakarae River. The uplift distribution from the fluvial and marine terraces combined agreed with the earlier inference that these terraces are coseismic and likely related to a near-shore, upper plate fault. Moreover, results from elastic dislocation modelling included in their study also suggest that this rupture may have continued onto the subduction interface beneath.

At Mahia Peninsular, Berryman (1993 a, b) surveyed the present-day elevation of the Pleistocene terraces preserved there to calculate an uplift rate of $\sim 1 \mathrm{~mm} / \mathrm{yr}$, while younger marine terraces indicate an increase in uplift rate for the Holocene of $\sim 3 \mathrm{~mm} / \mathrm{yr}$. As with the terraces preserved further north, Berryman $(1993 \mathrm{a}, \mathrm{b})$ inferred that these are also a result of repeated rupture of an upper plate fault, in this instance the nearby Lachlan Fault. Similarly, further south along the coast, Berryman et al. (2011) interpreted the stepped sequence of Holocene marine terraces as recording coseismic uplift from rupture on a number of upper plate faults situated close offshore; for instance, at the southern end of the east coast, marine terraces have been inferred to be the result of coseismic deformation of the nearby offshore PalliserKaiwhata Fault. Comparisons of these coastal terraces with inland fluvial terraces (Litchfield $\&$ Clark, 2015) have constrained the slip rate of that structure to $\sim 2.5 \mathrm{~mm} / \mathrm{yr}$.

Finite element modelling by Lichfield et al. (2007), which included uplift rates determined from marine terraces and incision rates measured from fluvial terraces across the entire length of the eastern North Island, suggests that broad-wavelength uplift patterns are related to processes such as the subduction of an overthickened and buoyant Hikurangi plateau. In contrast, higher uplift rates which were localised across the northern and central margin, were 
interpreted to result from both sediment underplating (the accumulation of sediments between the subducting plate and the upper plate), and seamount subduction beneath that region.

Despite an absence of reports for uplift caused by subduction earthquakes from studies of marine and fluvial terraces of the northern and central North Island, paleoecological studies from near Hawkes Bay do show evidence for a number of likely subduction earthquake-related subsidence events in the central North Island during the Holocene (Cochran et al., 2006; Hayward et al, 2006). Similar investigative methods have also revealed evidence for past subduction earthquakes at the top of the South Island, with the timing of these events constrained to $\sim 500$ years and $\sim 840$ years ago (Clark et al., 2015).

Across the lower North Island of New Zealand, present-day vertical deformation as a result of the interseismic strain accumulation associated with the locked portion of the underlying subduction interface, has been quantified (Beavan \& Litchfield, 2012; Houlie \& Stern, 2017). At the east coast of the lower North Island, the region between Cape Palliser and Palliser Bay is undergoing subsidence of $\sim 3-4 \mathrm{~mm} / \mathrm{yr}$; in the Wellington area, subsidence is $\sim 2-3 \mathrm{~mm} / \mathrm{yr}$, while the region west of Wellington is undergoing uplift of $\sim 1-2 \mathrm{~mm} / \mathrm{yr}$. To compare interseismic vertical deformation with long-term deformation in this region, at the eastern lower North Island, Lamb \& Vella (1987) estimated uplift, based on deformation patterns of Pleistocene sediments, of $\sim 1.75 \mathrm{~mm} / \mathrm{yr}$ for the last $\sim 200 \mathrm{ka}$.

The $\mathrm{M}_{\mathrm{w}}$ 7.8 Kaikoura earthquake of 14 November 2016, which struck the northern South Island, involved the almost-simultaneous rupture of multiple upper-plate faults within the Marlborough Fault system and most likely rupture along part of the underlying subduction interface (Hamling et al., 2017). After this event, geodetic data indicated that the regions of weak coupling on the subduction interface, near Gisborne and Hawkes Bay in the central North Island as well as Kapiti-Manawatu in the southwestern North Island (see Fig. 1.2), commenced aseismically slipping (L. Wallace, pers. comm., Dec 2016). Although these regions have experienced slow slip events previously (Wallace \& Beavan, 2010), they have never, to our knowledge, all slipped simultaneously. It is not known how the currently locked zone of the subduction interface beneath the southern North Island will respond to the change in stress resulting from this earthquake and subsequent slow slip events; however current probabilistic estimates (Kaiser et al., 2017) suggest that the risk of a large earthquake of $>M_{w} 7.8$ at the southern North Island has increased slightly. It has previously been estimated that sudden slip on the locked interface beneath this region could result in an earthquake of $\mathrm{M}_{\mathrm{w}}$ 8.0-8.5 or larger (Reyners, 1998; Wallace et al., 2009). 


\subsection{Previous Work}

Previous attempts to quantify tectonic deformation based on the fluvial terraces offset by the Wellington Fault, and the uplifted marine terraces on the south coast of the North Island, are summarised briefly below; a more detailed summation is provided in the relevant chapters of this thesis.

The Wellington Fault offsets fluvial terraces at a number of locations along its southernmost section, which extends from offshore in Cook Strait (e.g. Pondard \& Barnes, 2010), to near Kaitoke, north of Wellington (see Fig. 1.3). The fault-offset fluvial terraces examined in this study, namely those at Emerald Hill and Kaitoke Lakes, north of Wellington, have been subject to a number of previous studies (Lensen, 1973; Berryman, 1990; Grapes, 1993). Fault offset measurements from these earlier studies were made using imprecise and now-outdated surveying techniques and terrace ages were estimated by stratigraphic correlation with what were considered equivalent terraces elsewhere in the North Island, whose ages were thought to be better estimated. These studies yielded a diversity of fault-displacement measurements and age estimates for the same terraces, which resulted in a lack of consensus regarding slip rate on the Wellington Fault.

The uplifted marine terraces along the south coast, in particular their distribution, age, elevation and coverbed stratigraphy, have also been investigated previously (Ghani, 1974, 1978; Ota et al., 1981; Begg \& Mazengarb, 1996). Although identified and mapped, these earlier studies did not include any radiometric dating of terrace coverbed deposits to accurately determine the age of the terraces. In addition, terrace elevations were poorly determined due to rudimentary surveying technologies available at the time. Moreover, the paleo-sea level datum was measured from the variably sediment-mantled terrace treads rather than the wave-cut shore platform, unnecessarily and incorrectly including the thickness of coverbeds in elevation estimates. During this investigation I recorded variations of coverbed thickness between sites, in places as much as $30 \mathrm{~m}$, indicating that previous attempts at margin-wide terrace correlations and corresponding uplift estimates could have large uncertainties.

\subsection{Thesis format}

Following this Introduction chapter (Chapter 1), this thesis is structured as follows:

In Chapter 2, I present results from the investigation of late Quaternary slip on the Wellington Fault, as inferred from an analysis of fault-offset fluvial terraces at three sites along the Hutt River, north of Wellington (see Fig. 1.3) - Emerald Hill (Fig. 1.8), Kaitoke Lakes and Dry 
Creek. Where they are cut by the fault, the differential displacement of these terraces provides evidence of progressive slip on the fault for the last $\sim 100 \mathrm{ka}$. As these offset terraces have been partially destroyed due to housing development, my investigation relied on archival aerial photos, using modern photogrammetric techniques to produce high resolution digital elevation data from these. The topographical information derived from this process allowed me to quantify the displacement of the offset terraces with unprecedented precision. Moreover, the recent advances in sediment dating techniques now provide more precise age control for such geomorphological investigations. I employed Optically Stimulated Luminescence (OSL) and radiocarbon dating to accurately constrain the age of these terraces. The greater part of Chapter 2 was published in 2013 (Ninis et al., 2013). However, this thesis chapter contains additional results from Kaitoke Lakes, which were not included in the publication.

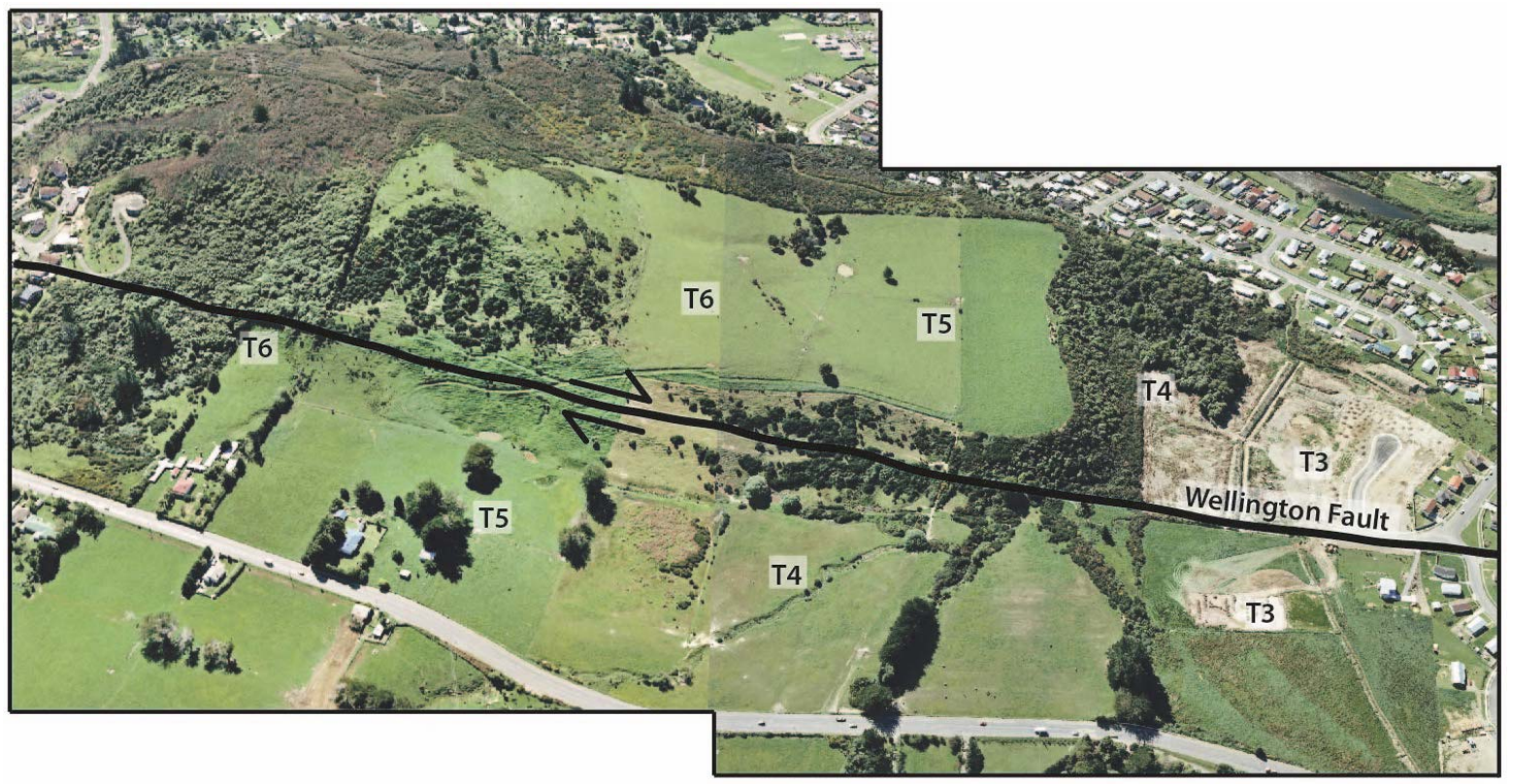

Figure 1.8. Aerial photo of the Emerald Hill field site, taken in 1988, when the new housing development had just begun. Approximate location of the Wellington Fault is shown, as are some of the preserved fluvial terraces, prefixed with ' $\mathrm{T}$ ' - terrace numbers increase with terrace age. Viewed looking towards the northwest. Photo taken by L. Homer - GNS Science Visual Media Library VML ID: 21047; 21048, Catalogue Numbers: 13091/4; 13092/6.

In Chapter 3, I describe the distribution and age of late Pleistocene marine terraces spanning $\sim 100 \mathrm{~km}$ along the south coast of the North Island. Once at sea level, these terraces have been elevated to current-day heights of up to $\sim 400 \mathrm{~m}$ since their formation in the last $\sim 300 \mathrm{ka}$. Uplifted ancient shore platforms were identified at a number of sites, for example almost continuously along the Palliser Bay coast (see Fig. 1.3), from Cape Palliser (Fig. 1.9) to Lake 
Ferry, as well as sites further to the west at Wharekauhau, Baring Head and Tongue Point (Fig. 1.10). Improvements in surveying methods in recent times allow for more accurate elevation estimates than in previous studies. My investigation of these terraces involved mapping and Global Navigational Satellite Systems (GNSS) surveying of terrace features, as well as logging and sampling of coverbed deposits. Samples collected were dated using OSL analysis, and the ages obtained were then further constrained by the timing of major sea-level highstands, when the shore platforms were likely to have been formed.

In Chapter 4 I use the ages and elevation data of the Pleistocene marine terraces presented in Chapter 3, to calculate uplift rates across the southern Hikurangi margin. Because the ancient shoreline is now obscured by colluvium, I calculate a plane of best fit for the shore platform, based on our surveyed elevation data, and project this surface landward, towards its intersection with the former sea cliff, in order to determine the strandline elevation. I also make use of the latest available results in eustatic sea level reconstructions, and use these new estimates in our uplift calculations, thereby presenting the most robust uplift calculations for the southern Hikurangi margin available to date.

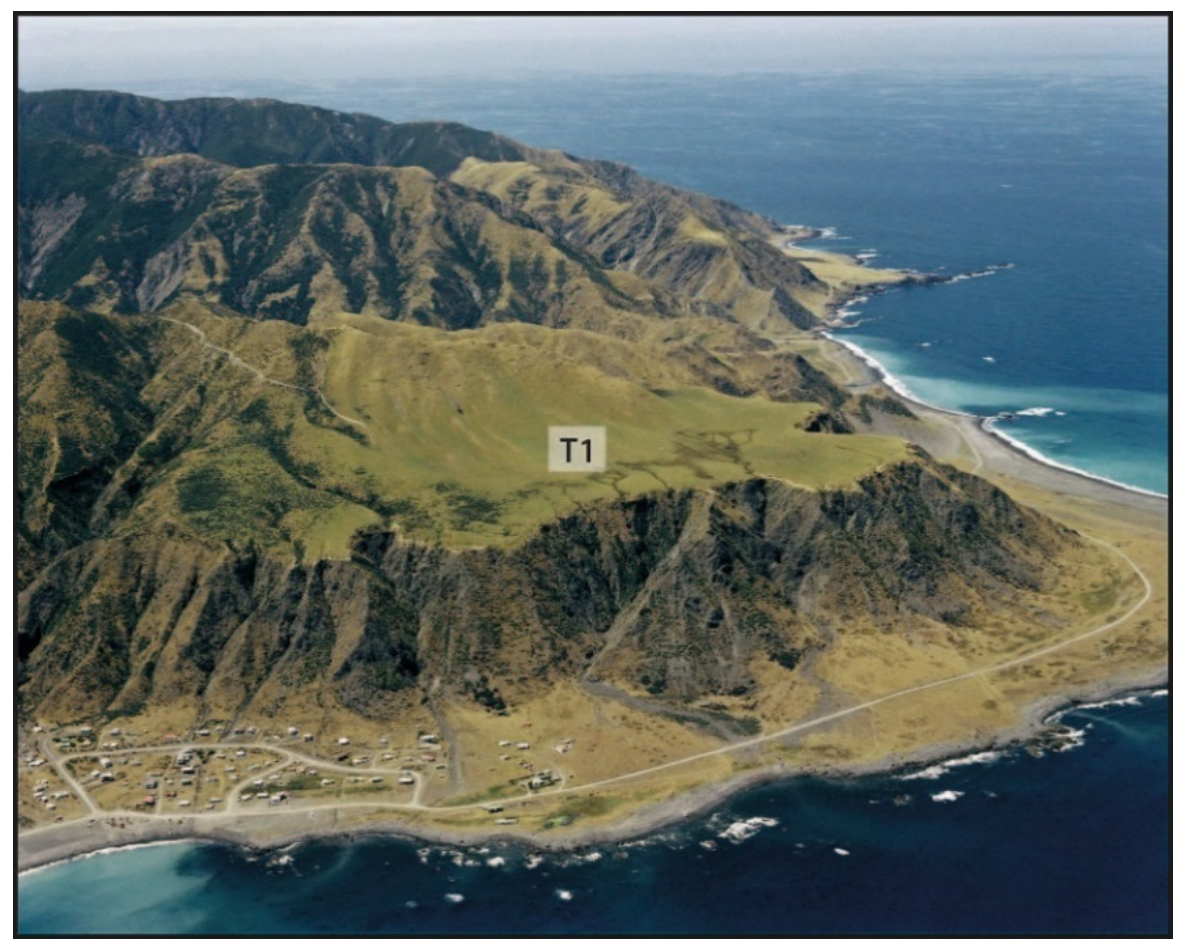

Figure 1.9. The easternmost preserved Pleistocene marine terrace on the south coast, North Island, at Ngawi near Cape Palliser (see Fig. 1.3 for location). Only one terrace is preserved here, T1. View looking towards the east. Photo taken by L. Homer - GNS Science Visual Media Library VML ID: 9025, Catalogue Number: 1163/7. 
To conclude, in Chapter 5 I summarise the main outcomes of my investigations, discuss the implications of my results as they apply to subduction processes, and close with suggestions for further work which would complement this study.

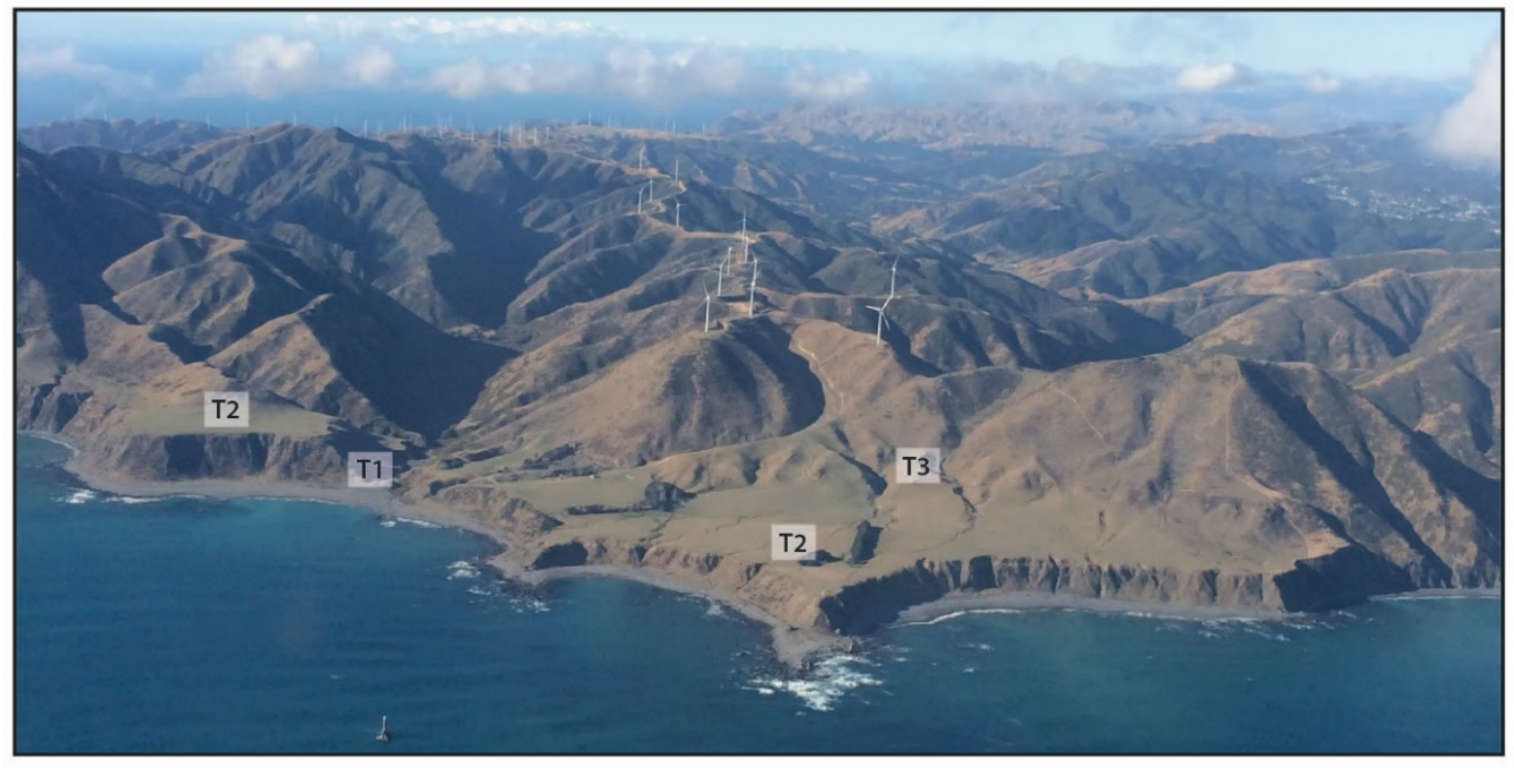

Figure 1.10. The marine terraces preserved at Tongue Point, west of Wellington (see Fig. 1.3 for location). Three Pleistocene terraces are preserved at this site. The main, coastal most terrace here is $\mathrm{T} 2$, and a hummocky strip is all that remains of an older, higher terrace, T3. Only a few remnants of the youngest terrace, T1, remain - these are not easily viewed in this photograph. View looking towards the north. 


\section{References}

Ansell, J.H. and Bannister, S.C., 1996. Shallow morphology of the subducted Pacific plate along the Hikurangi margin, New Zealand. Physics of the earth and planetary interiors, 93(1-2), pp.320.

Barker, D.H., Sutherland, R., Henrys, S. and Bannister, S., 2009. Geometry of the Hikurangi subduction thrust and upper plate, North Island, New Zealand. Geochemistry, Geophysics, Geosystems, 10(2).

Barnes, P. M., and Mercier de Lepinay, B., 1997. Rates and mechanics of rapid frontal accretion along the very obliquely convergent southern Hikurangi margin, New Zealand, J. Geophys. Res. 102 , B11, 24931-24952.

Barnes, P. M., Mercier de Lepinay, B., Collot, J-Y., Delteil, J. and Audru, J-C., 1998. Strain partitioning in the transition area between oblique subduction and continental collision, Hikurangi margin, New Zealand, Tectonics. 17 534-557.

Barnes, P. M., and Audru, J. C., 1999. Quaternary faulting in the offshore Flaxbourne and Wairarapa basins, southern Cook Strait, New Zealand. New Zealand Journal of Geology and Geophysics, 42(3): 349-367.

Bassett, D., Sutherland, R., Henrys, S., Stern, T., Scherwath, M., Benson, A., Toulmin, S. and Henderson, M., 2010. Three-dimensional velocity structure of the northern Hikurangi margin, Raukumara, New Zealand: Implications for the growth of continental crust by subduction erosion and tectonic underplating. Geochemistry, Geophysics, Geosystems, 11(10).

Beanland, S., 1995. The North Island dextral fault belt, Hikurangi subduction margin, New Zealand, Ph.D. thesis. Victoria University of Wellington, Wellington, New Zealand.

Beanland, S., Melhuish, A., Nicol, A. and Ravens, J., 1998. Structure and deformational history of the inner forearc region, Hikurangi subduction margin, New Zealand. New Zealand Journal of Geology and Geophysics, 41(4), pp.325-342.

Beavan, R.J. and Litchfield, N.J., 2012. Vertical land movement around the New Zealand coastline: implications for sea-level rise. GNS Science Report 2012/29. 41 p.

Begg, J.G. and Mazengarb, C., 1996. Geology of the Wellington area: sheets R27, R28, and part Q27, scale 1:50,000. Lower Hutt: Institute of Geological \& Nuclear Sciences. Institute of Geological \& Nuclear Sciences geological map 22. 128 p. + 1 fold map.

Begg, J.G. and Johnston, M.R., 2000. Geology of the Wellington area. 1: 250000 Geological map 10. Institute of Geological and Nuclear Sciences, Lower Hutt, New Zealand.

Benedetti, L., Finkel, R., Papanastassiou, D., King, G., Armijo, R., Ryerson, F., Farber, D. and Flerit, F., 2002. Post-glacial slip history of the Sparta fault (Greece) determined by $36 \mathrm{Cl}$ cosmogenic dating: evidence for non-periodic earthquakes. Geophysical Research Letters, 29(8).

Bennett, R. A., Friedrich, A. M. and Furlong, K. P., 2004. Co-dependent histories of the San Andreas and San Jacinto fault zones from inversion of fault displacement rates, Geology, 32, no. 11, 961-964, doi: 10.1130/G20806.1.

Berryman, K.R., Ota, Y., and Hull, A.G., 1989. Holocene palaeoseismicity in the fold and thrust belt of the Hikurangi subduction zone, eastern North Island, New Zealand. Tectonophysics, Vol. 163: 185-195. 
Berryman, K. R. 1990. Late Quaternary movement on the Wellington Fault in the Upper Hutt area, New Zealand, New Zeal. J. Geol. Geophys. 33 257-270.

Berryman, K., 1993 (a). Age, height, and deformation of Holocene marine terraces at Mahia Peninsula, Hikurangi subduction margin, New Zealand. Tectonics, 12(6), pp.1347-1364.

Berryman, K.R., 1993 (b). Distribution, age, and deformation of late Pleistocene marine terraces at Mahia Peninsula, Hikurangi subduction margin, New Zealand. Tectonics, 12(6), pp.13651379.

Berryman, K., Ota, Y., Miyauchi, T., Hull, A., Clark, K., Ishibashi, K., Iso, N. and Litchfield, N., 2011. Holocene paleoseismic history of upper-plate faults in the southern Hikurangi subduction margin, New Zealand, deduced from marine terrace records. Bulletin of the Seismological Society of America, 101(5), pp.2064-2087.

Bourne, M. and Stuart, G., 2000. ScSp observed on North Island, New Zealand: implications for subducting plate structure. Geophysical Journal International, 142(3), pp.925-932.

Bradley, W. C., and Griggs, G. B., 1976. Form, genesis, and deformation of central California wavecut platforms. Geological Society of America Bulletin 87, no. 3: 433-449.

Briggs, R.W., Sieh, K., Meltzner, A.J., Natawidjaja, D., Galetzka, J., Suwargadi, B., Hsu, Y.J., Simons, M., Hananto, N., Suprihanto, I. and Prayudi, D., 2006. Deformation and slip along the Sunda megathrust in the great 2005 Nias-Simeulue earthquake. Science, 311(5769), pp.1897-1901.

Carver, G.A., Jayko, A.S., Valentine, D.W. and Li, W.H., 1994. Coastal uplift associated with the 1992 Cape Mendocino earthquake, northern California. Geology, 22(3), pp.195-198.

Clark, K.J., Hayward, B.W., Cochran, U.A., Wallace, L.M., Power, W.L. and Sabaa, A.T., 2015. Evidence for past subduction earthquakes at a plate boundary with widespread upper plate faulting: Southern Hikurangi margin, New Zealand. Bulletin of the Seismological Society of America.

Clark, K. J., Nissen, E. K., Howarth, J. D., Hamling, I.J., Mountjoy, J. J., Ries, W. F., Jones, K., Goldstien, S., Cochran, U. A., Villamor, P., Hreinsdóttir, S., Litchfield, N. J., Mueller, C., Berryman, K. R., and Strong, D. T., 2017. Highly variable coastal deformation in the 2016 MW7.8 Kaikoura earthquake reflects rupture complexity along a transpressional plate boundary. Earth and Planetary Science Letters, in press.

Cochran, U., Berryman, K., Zachariasen, J., Mildenhall, D., Hayward, B., Southall, K., Hollis, C., Barker, P., Wallace, L., Alloway, B. and Wilson, K., 2006. Paleoecological insights into subduction zone earthquake occurrence, eastern North Island, New Zealand. Geological Society of America Bulletin, 118(9-10), pp.1051-1074.

Darby, D. and Beavan, J., 2001. Evidence from GPS measurements for contemporary interpolate coupling on the southern Hikurangi subduction thrust and for partitioning of strain in the upper plate, J. Geophys. Res. 106, no. 12, 30881-30891.

Davy, B. and Wood, R., 1994. Gravity and magnetic modelling of the Hikurangi Plateau. Marine geology, 118(1-2), pp.139-151.

DeMets, C., Gordon, R. G., Argus, D. F., and Stein, S., 1990. Current plate motions, Geophys. J. Int. $101425-478$. 
DeMets, C., Gordon, R. G., Argus, D. F., and Stein, S., 1994. Effect of Recent Revisions to the Geomagnetic Reversal Time Scale on Estimates of Current Plate Motions, Geophys. Res. Lett. 21 2191-2194.

DeMets, C., Gordon, R.G. and Argus, D.F., 2010. Geologically current plate motions. Geophysical Journal International, 181(1), pp.1-80.

Doser, D.I. and Webb, T.H., 2003. Source parameters of large historical (1917-1961) earthquakes, North Island, New Zealand. Geophysical Journal International, 152(3), pp.795-832.

Fitch, T.J. and Scholz, C.H., 1971. Mechanism of underthrusting in southwest Japan: A model of convergent plate interactions. Journal of Geophysical Research, 76(29), pp.7260-7292.

Gardner, T., 2011. Late Holocene deformation, fold, growth and the seismic cycle, Kaikoura Peninsular, South Island, New Zealand. In GSA Annual Meeting in Minneapolis, Oct. 2011.

Ghani, M. A. 1974. Late Cenozoic vertical crustal movements in the southern North Island, New Zealand. Ph.D. thesis. Victoria University of Wellington, Wellington, New Zealand.

Ghani, M. A. 1978. Late Cenozoic vertical crustal movements in the southern North Island, New Zealand. New Zeal. J. Geol. Geophys. Volume 21, Issue 1, 1978.

Grantz, A., Plafker, G. and Kachadoorian, R., 1964. Alaska's Good Friday earthquake, March 27, 1964: A preliminary geologic evaluation (Vol. 491). US Department of the Interior, Geological Survey.

Grapes, R. 1993. Terrace correlation, dextral displacements, and slip rate along the Wellington Fault, North Island, New Zealand (Letters to the Editor), New Zeal. J. Geol. Geophys. 36 131-135.

Hamling, I.J., Hreinsdóttir, S., Clark, K., Elliott, J., Liang, C., Fielding, E., Litchfield, N., Villamor, P., Wallace, L., Wright, T.J. and D’Anastasio, E., 2017. Complex multifault rupture during the 2016 Mw 7.8 Kaikōura earthquake, New Zealand. Science, p.eaam7194.

Hayward, B.W., Grenfell, H.R., Sabaa, A.T., Carter, R., Cochran, U., Lipps, J.H., Shane, P.R. and Morley, M.S., 2006. Micropaleontological evidence of large earthquakes in the past 7200 years in southern Hawke's Bay, New Zealand. Quaternary Science Reviews, 25(11), pp.11861207.

Henrys, S., Wech, A., Sutherland, R., Stern, T., Savage, M., Sato, H., Mochizuki, K., Iwasaki, T., Okaya, D., Seward, A. and Tozer, B., 2013. SAHKE geophysical transect reveals crustal and subduction zone structure at the southern Hikurangi margin, New Zealand. Geochemistry, Geophysics, Geosystems, 14(7), pp.2063-2083.

Houlié, N. and Stern, T.A., 2017. Vertical tectonics at an active continental margin. Earth and Planetary Science Letters, 457, pp.292-301.

Hull, A.G., 1990: Tectonics of the 1931 Hawke's Bay earthquake. New Zealand Journal of Geology \& Geophysics, Vol. 33: 309-320.

Kamp, P.J., 1999. Tracking crustal processes by FT thermochronology in a forearc high (Hikurangi margin, New Zealand) involving Cretaceous subduction termination and mid-Cenozoic subduction initiation. Tectonophysics, 307(3), pp.313-343.

Kaiser, A., Balfour, N., Fry, B., Holden, C., Litchfield, N., Gerstenberger, M., D’Anastasio, E., Horspool, N., McVerry, G., Ristau, J. and Bannister, S., 2017. The 2016 Kaikōura, New Zealand, Earthquake: Preliminary Seismological Report. Seismological Research Letters. 
Kneupfer, P. L. K. 1992. Temporal variations in latest Quaternary slip across the Australian-Pacific Plate Boundary, north eastern South Island, New Zealand, Tectonics. 11, no. 3, 449-464, doi:10.1029/91TC02890.

Konca, A.O., Hjorleifsdottir, V., Song, T.R.A., Avouac, J.P., Helmberger, D.V., Ji, C., Sieh, K., Briggs, R. and Meltzner, A., 2007. Rupture kinematics of the $2005 \mathrm{Mw} 8.6$ Nias-Simeulue earthquake from the joint inversion of seismic and geodetic data. Bulletin of the Seismological Society of America, 97(1A), pp.S307-S322.

Lamb, S.H. and Vella, P., 1987. The last million years of deformation in part of the New Zealand plate-boundary zone. Journal of structural geology, 9(7), pp.877-891.

Lensen, G. J. 1973. Guidebook for Excursion A10: Central New Zealand, IX INQUA Congress 1973, Christchurch, New Zealand, 2-24.

Litchfield, N., Ellis, S., Berryman, K., and Nicol, A., 2007: Insights into subduction-related uplift along the Hikurangi Margin, New Zealand, using numerical modelling. Journal of Geophysical Research, Vol. 112, F02021, doi: 10.1029/2006JF000535.

Litchfield, N., Wilson, K., Berryman, K. and Wallace, L., 2010. Coastal uplift mechanisms at Pakarae River mouth: Constraints from a combined Holocene fluvial and marine terrace dataset. Marine Geology, 270(1), pp.72-83.

Litchfield, N.J. and Clark, K.J., 2015. Fluvial terrace formation in the lower Awhea and Pahaoa River valleys, New Zealand: implications for tectonic and sea-level controls. Geomorphology, 231, pp.212-228.

Litchfield, N.J., Cochran, U.A., Berryman, K.R., Clark, K.J., McFadgen, B.G. and Steele, R. 2016. Gisborne seismic and tsunami hazard: constraints from marine terraces at Puatai Beach, GNS Science Report 2016/21. 99 p.

Little, T.A., Van Dissen, R., Schermer, E. and Carne, R., 2009. Late Holocene surface ruptures on the southern Wairarapa fault, New Zealand: Link between earthquakes and the uplifting of beach ridges on a rocky coast. Lithosphere, 1(1), pp.4-28.

Little, T.A., Van Dissen, R., Rieser, U., Smith, E.G. and Langridge, R.M., 2010. Coseismic strike slip at a point during the last four earthquakes on the Wellington fault near Wellington, New Zealand. Journal of Geophysical Research: Solid Earth, 115(B5).

Marshall, J.S. and Anderson, R.S., 1995. Quaternary uplift and seismic cycle deformation, Peninsula de Nicoya, Costa Rica. Geological Society of America Bulletin, 107(4), pp.463-473.

Matsu'ura, T., 2015. Late Quaternary uplift rate inferred from marine terraces, Muroto Peninsula, southwest Japan: Forearc deformation in an oblique subduction zone. Geomorphology, 234, pp.133-150.

Matsu'ura, M. and Sato, T., 1989. A dislocation model for the earthquake cycle at convergent plate boundaries. Geophysical Journal International, 96(1), pp.23-32.

Matsu'ura, T., Furusawa, A. and Saomoto, H., 2009. Long-term and short-term vertical velocity profiles across the forearc in the NE Japan subduction zone. Quaternary Research, 71(2), pp.227-238.

McSaveney, M.J., Graham, I.J., Begg, J.G., Beu, A.G., Hull, A.G., Kim, K. and Zondervan, A., 2006. Late Holocene uplift of beach ridges at Turakirae Head, south Wellington coast, New Zealand. New Zealand Journal of Geology and Geophysics, 49(3), pp.337-358. 
Merritts, D. and Bull, W.B., 1989. Interpreting Quaternary uplift rates at the Mendocino triple junction, northern California, from uplifted marine terraces. Geology, 17(11), pp.1020-1024.

Merritts, D.J., 1996. The Mendocino triple junction: Active faults, episodic coastal emergence, and rapid uplift. Journal of Geophysical Research: Solid Earth, 101(B3), pp.6051-6070.

Mitchell, J.S., Mackay, K.A., Neil, H.L., Mackay, E.J., Pallentin, A., Notman, P. (2012) Undersea New Zealand, 1:5,000,000 NIWA Chart, Miscellaneous Series No. 92.

Mountjoy, J.J. and Barnes, P.M., 2011. Active upper plate thrust faulting in regions of low plate interface coupling, repeated slow slip events, and coastal uplift: Example from the Hikurangi Margin, New Zealand. Geochemistry, Geophysics, Geosystems, 12(1).

Muhs, D. R., Kelsey, H. M., Miller, G. H., Kennedy, G. L., Whelan, J. F., \& McInelly, G. W., 1990. Age estimates and uplift rates for late pleistocene marine terraces' Southern Oregon portion of the Cascadia forearc. J. Geophys. Res. 95, no. B5, 6685-6698.

Murray, M.H., Marshall, G.A., Lisowski, M. and Stein, R.S., 1996. The 1992 M= 7 Cape Mendocino, California, earthquake: Coseismic deformation at the south end of the Cascadia megathrust. Journal of Geophysical Research: Solid Earth, 101(B8), pp.17707-17725.

Nelson, A.R. and Manley, W.F., 1992. Holocene coseismic and aseismic uplift of Isla Mocha, southcentral Chile. Quaternary International, 15, pp.61-76.

Nicol, A., VanDissen, R., Vella, P., Alloway, B. and Melhuish, A., 2002. Growth of contractional structures during the last 10 my at the southern end of the emergent Hikurangi forearc basin, New Zealand. New Zealand Journal of Geology and Geophysics, 45(3), pp.365-385.

Nicol, A., and Beavan, J., 2003: Shortening of an overriding plate and its implications for slip on a subduction thrust, central Hikurangi margin, New Zealand. Tectonics, Vol. 22, No. 6, doi10.1029/2003TC001521.

Nicol, A., Mazengarb, C., Chanier, F., Rait, G., Uruski, C. and Wallace, L., 2007. Tectonic evolution of the active Hikurangi subduction margin, New Zealand, since the Oligocene. Tectonics, 26(4).

Nicol, A. and Wallace, L.M., 2007. Temporal stability of deformation rates: Comparison of geological and geodetic observations, Hikurangi subduction margin, New Zealand. Earth and Planetary Science Letters, 258(3), pp.397-413.

Ninis, D., Little, T.A., Van Dissen, R.J., Litchfield, N.J., Smith, E.G., Wang, N., Rieser, U. and Henderson, C.M., 2013. Slip rate on the Wellington fault, New Zealand, during the late Quaternary: Evidence for variable slip during the Holocene. Bulletin of the Seismological Society of America, 103(1), pp.559-579.

Ortlieb, L., Zazo, C., Goy, J., Hillaire-Marcel, C., Ghaleb, B. and Cournoyer, L., 1996. Coastal deformation and sea-level changes in the northern Chile subduction area $(23 \mathrm{~S})$ during the last 330 ky. Quaternary Science Reviews, 15(8-9), pp.819-831.

Ota, Y., Williams, D.N. and Berryman, K.R., 1981. Late Quaternary Tectonic Map of New Zealand 1:50,000 Parts Sheets Q27, R27 \& R28. New Zealand Geological Survey, Lower Hutt.

Ota, Y., Hull, A.G. and Berryman, K.R., 1991. Coseismic uplift of Holocene marine terraces in the Pakarae River area, eastern North Island, New Zealand. Quaternary Research, 35(3), pp.331346. 
Ota, Y., Pillans, B., Berryman, K., Beu, A., Fujimori, T., Miyauchi, T. Berger, G., Beu, A. G. \& Climo, F. M., 1996. Pleistocene coastal terraces of Kaikoura Peninsula and the Marlborough coast, South Island, New Zealand. New Zealand journal of geology and geophysics, 39(1), 5173.

Pedoja, K., Ortlieb, L., Dumont, J.F., Lamothe, M., Ghaleb, B., Auclair, M. and Labrousse, B., 2006. Quaternary coastal uplift along the Talara Arc (Ecuador, Northern Peru) from new marine terrace data. Marine Geology, 228(1), pp.73-91.

Plafker, G., 1965: Tectonic deformation associated with the 1964 Alaska earthquake. Science, Vol. 148, No. 3678: 1675-1687.

Plafker, G., 1972. Alaskan earthquake of 1964 and Chilean earthquake of 1960: Implications for arc tectonics. Journal of Geophysical Research, 77(5), pp.901-925.

Pondard, N. and Barnes, P.M., 2010. Structure and paleoearthquake records of active submarine faults, Cook Strait, New Zealand: Implications for fault interactions, stress loading, and seismic hazard. Journal of Geophysical Research: Solid Earth (1978-2012), 115(B12).

Reid, H.F., 1910. The mechanism of the earthquake, The California earthquake of April 18, 1906. Report of the Research Senatorial Commission, Carnegie Institution, Washington, DC, 2, pp.16-18.

Reyners, M., 1998. Plate coupling and the hazard of large subduction thrust earthquakes at the Hikurangi subduction zone, New Zealand, New Zeal. J. Geol. Geophys. 41 343-354.

Reyners, M., Eberhart-Phillips, D., Stuart, G. and Nishimura, Y., 2006. Imaging subduction from the trench to $300 \mathrm{~km}$ depth beneath the central North Island, New Zealand, with Vp and Vp/Vs. Geophysical Journal International, 165(2), pp.565-583.

Reyners, M., Eberhart-Phillips, D. and Bannister, S., 2011. Tracking repeated subduction of the Hikurangi Plateau beneath New Zealand. Earth and Planetary Science Letters, 311(1-2), pp.165-171.

Rodgers, D.W. and Little, T.A., 2006. World's largest coseismic strike-slip offset: The 1855 rupture of the Wairarapa Fault, New Zealand, and implications for displacement/length scaling of continental earthquakes. Journal of Geophysical Research: Solid Earth, 111(B12).

Saillard, M., Hall, S.R., Audin, L., Farber, D.L., Hérail, G., Martinod, J., Regard, V., Finkel, R.C. and Bondoux, F., 2009. Non-steady long-term uplift rates and Pleistocene marine terrace development along the Andean margin of Chile (31 S) inferred from 10 Be dating. Earth and Planetary Science Letters, 277(1), pp.50-63.

Saillard, M., Hall, S.R., Audin, L., Farber, D.L., Regard, V. and Hérail, G., 2011. Andean coastal uplift and active tectonics in southern Peru: 10 Be surface exposure dating of differentially uplifted marine terrace sequences (San Juan de Marcona, 15.4 S). Geomorphology, 128(3), pp.178-190.

Sato, T. and Matsu'Ura, M., 1993. A kinematic model for evolution of island arc-trench systems. Geophysical Journal International, 114(3), pp.512-530.

Savage, J.C., 1983. A dislocation model of strain accumulation and release at a subduction zone. Journal of Geophysical Research: Solid Earth, 88(B6), pp.4984-4996.

Shikakura, Y., 2014. Marine terraces caused by fast steady uplift and small coseismic uplift and the time-predictable model: Case of Kikai Island, Ryukyu Islands, Japan. Earth and Planetary Science Letters, 404, pp.232-237. 
Stirling, M., McVerry, G., Gerstenberger, M., Litchfield, N., Van Dissen, R., Berryman, K., Barnes, P., Wallace, L. M., Bradley, B., Villamor, P., Langridge, R. M., Lamarche, G., Noder, S., Reyners, M., Rhoades, D., Smith, W., Nicol, A., Pettinga, J., Clark, K., Jacobs, K., 2012. National seismic hazard model for New Zealand: 2010 update, Bull. Seism. Soc. Am. 102 1514-1542.

Subarya, C., Chlieh, M., Prawirodirdjo, L., Avouac, J.P., Bock, Y., Sieh, K., Meltzner, A.J., Natawidjaja, D.H. and McCaffrey, R., 2006. Plate-boundary deformation associated with the great Sumatra-Andaman earthquake. Nature, 440(7080), pp.46-51.

Thatcher, W., 1984. The earthquake deformation cycle at the Nankai Trough, southwest Japan. Journal of Geophysical Research: Solid Earth, 89(B5), pp.3087-3101.

Van Dissen, R. and Berryman, K. R. 1996. Surface rupture earthquakes over the last $\sim 1000$ years in the Wellington region, New Zealand, and implications for ground shaking hazard, J. Geophys. Res. 101, B3, 5999-6019.

Vigny, C., Socquet, A., Peyrat, S., Ruegg, J.C., Métois, M., Madariaga, R., Morvan, S., Lancieri, M., Lacassin, R., Campos, J. and Carrizo, D., 2011. The $2010 \mathrm{Mw} 8.8$ Maule megathrust earthquake of Central Chile, monitored by GPS. Science, 332(6036), pp.1417-1421.

Walcott, R.I., 1978. Geodetic strains and large earthquakes in the axial tectonic belt of North Island, New Zealand. Journal of Geophysical Research: Solid Earth, 83(B9), pp.4419-4429.

Walcott, R.I., 1984. The kinematics of the plate boundary zone through New Zealand: a comparison of short-and long-term deformations. Geophysical Journal International, 79(2), pp.613-633.

Wallace, L.M., Beavan, J., McCaffrey, R. and Darby, D., 2004. Subduction zone coupling and tectonic block rotations in the North Island, New Zealand. Journal of Geophysical Research: Solid Earth, 109(B12).

Wallace, L.M., Beavan, J., McCaffrey, R., Berryman, K. and Denys, P., 2007. Balancing the plate motion budget in the South Island, New Zealand using GPS, geological and seismological data. Geophysical Journal International, 168(1), pp.332-352.

Wallace, L.M., Reyners, M., Cochran, U., Bannister, S., Barnes, P.M., Berryman, K., Downes, G., Eberhart-Phillips, D., Fagereng, A., Ellis, S. and Nicol, A., 2009. Characterizing the seismogenic zone of a major plate boundary subduction thrust: Hikurangi Margin, New Zealand. Geochemistry, Geophysics, Geosystems, 10(10).

Wallace, L.M. and Beavan, J., 2010. Diverse slow slip behavior at the Hikurangi subduction margin, New Zealand. Journal of Geophysical Research: Solid Earth, 115(B12).

Wallace, L. M., Barnes, P., Beavan, J., Van Dissen, R. J., Litchfield, N. J., Mountjoy, J., Langridge, R. M., Lamarche, G., and Pondard, H., 2012. The kinematics of a transition from subduction to strike-slip: an example from the central New Zealand plate boundary, J. Geophys. Res. Solid Earth, doi: 10.1029/2011JB008640.

Williams, C.A., Eberhart-Phillips, D., Bannister, S., Barker, D.H., Henrys, S., Reyners, M. and Sutherland, R., 2013. Revised interface geometry for the Hikurangi subduction zone, New Zealand. Seismological Research Letters, 84(6), pp.1066-1073.

Wilson, K., Berryman, K., Litchfield, N. and Little, T., 2006. A revision of mid-late Holocene marine terrace distribution and chronology at the Pakarae River mouth, North Island, New Zealand. New Zealand Journal of Geology and Geophysics, 49(4), pp.477-489. 
Wilson, K., Litchfield, N., Berryman, K. and Little, T., 2007 (a). Distribution, age, and uplift patterns of Pleistocene marine terraces of the northern Raukumara Peninsula, North Island, New Zealand. New Zealand Journal of Geology and Geophysics, 50(3), pp.181-191.

Wilson, K., Berryman, K., Cochran, U. and Little, T., 2007 (b): Holocene coastal evolution and uplift mechanisms of the northeastern Raukumara Peninsula, North Island, New Zealand. Quaternary Science Reviews, 26(7), pp.1106-1128.

Yonekura, N. and Shimazaki, K., 1980. Uplifted marine terraces and seismic crustal deformation in arc-trench systems: A role of imbricated thrust faulting. Eos Trans. AGU, 61, p.1111. 


\title{
CHAPTER TWO
}

\section{SLIP RATE ON THE WeLLington FAuLt, NeW ZEALAND, DURING THE LATE QUATERNARY: \\ EVIDENCE FOR VARIAble SLIP DURING THE HOLOCEnE}

\begin{abstract}
We investigate fault-offset fluvial terraces at three sites along the Hutt River, near Wellington, New Zealand, to determine horizontal slip rates for the southern part of the Wellington Fault for the last $\sim 100 \mathrm{ka}$. Using photogrammetric analysis of historic aerial photos, we measured the original displacements of terrace risers at two sites, Emerald Hill and Kaitoke Lakes, which have been modified by urban development. Nineteen sediment samples from this site and from a third location, Dry Creek, were analysed using Optically Stimulated Luminescence (OSL) methods, yielding ages of between $\sim 10 \mathrm{ka}$ and $\sim 100 \mathrm{ka}$. From our displacement-age relations, we estimate an average slip rate of $6.3 \pm{ }_{1.2}^{1.9} \mathrm{~mm} / \mathrm{yr}(2 \sigma)$ during the last $\sim 100 \mathrm{ka}$. However, slip on the Wellington Fault has not been steady throughout this time. During the Holocene, there was a phase of heightened ground rupture activity between $\sim 10-8 \mathrm{ka}$, when an incremental dextral displacement of $\sim 32 \mathrm{~m}$ accrued. This was followed by a period of relative quiescence between $\sim 8-4.5 \mathrm{ka}$, with $\sim 5 \mathrm{~m}$ of displacement during this time. Another period of heightened activity followed, resulting in a further $\sim 20 \mathrm{~m}$ of slip during the last $\leq 4.5 \mathrm{ka}$. Our inference of variable slip during the Holocene accords with independent evidence from paleoseismological studies at other sites along the Wellington Fault. Slip on the Wellington Fault, and its variability through time, may be influenced by activity on neighbouring faults.
\end{abstract}

\subsection{Introduction}

The slip rate of a fault is a function of the magnitude and frequency of ground rupture earthquakes. Slip rate calculations require measurement of fault displacements as well as the age of the faulted markers. The greater the number of such paired displacement and age data, the more detailed will be the reconstructed history of slip on that fault. Records of cumulative displacement through time provide information about any temporal variability of fault slip and, 
by inference, of ground rupture earthquakes. To what degree the slip rate of a fault might change through time is a significant question for understanding fault behaviour and estimating seismic hazard. Understanding temporal variability of fault slip may also provide insight into the associated geodynamic processes and help us to understand how large earthquakes are generated.

Temporal clustering of fault surface rupture has been inferred previously from paleoseismological studies (e.g. Grant and Sieh, 1994; Marco et al., 1996; Rockwell et al., 2000; Friedrich et al., 2003; Dawson et al., 2003; Langridge et al., 2009; Ganev et al., 2010). Such studies rely on a continuous geological record to capture evidence of successive historic ground rupture events, because a period of little or no sedimentation may be misinterpreted as a period of low or no fault activity. Strike-slip movement can be especially difficult to decipher from paleoseismological analysis of fault-perpendicular trenches because the lateral continuity of units may be difficult to trace in and out of the plane of the trench wall. Further, the duration of rupture history exposed in a trench is limited by its depth.

The temporal accumulation of fault slip across a sequence of different-aged landforms provides a potential alternative method for assessing earthquake ground-rupturing through time, and is better suited to quantifying strike-slip deformation. Where the average frequency of landform generation is greater than that of rupturing, moreover, the differential displacement of the dated landforms may provide evidence of the timing of earthquakes. This morphochronologic approach has the ability to provide information regarding the past activity of a fault over a much longer period of time than can be assessed by paleoseismological trenching studies alone. Morphochronology has been used elsewhere to provide evidence for non-steady slip rates on a number of faults (e.g. Kneupfer, 1992; Benedetti et al., 2002, Bennett et al., 2004).

Fluvial terraces are offset by the Wellington Fault at several sites along the Hutt River in the southern North Island, New Zealand. Previous studies of the terraces at Emerald Hill and Kaitoke Lakes, as well as other sites (Berryman, 1990; Grapes, 1993), yielded a diversity of fault-displacement measurements and age estimates for these features, and have resulted in a lack of consensus regarding the average or long-term slip rate on the Wellington Fault. We attempt to address these inconsistencies by: a) re-evaluating strike-slip estimates of the faulted fluvial terraces at Emerald Hill and, to a lesser extent, Kaitoke Lakes, using photogrammetry; b) radiometrically dating these terraces using Optically Stimulated Luminescence (OSL) methods; and c) assessing the evolution of slip and slip rate on the Wellington Fault during the last $\sim 100$ ka. 
In this chapter we not only offer a revised average dextral slip rate for the Wellington Fault for the last $\sim 100 \mathrm{ka}$, but we also present morphochronologic evidence for temporal variation in slip. We then discuss the possible causes of this non-steady fault slip behaviour. Comprehending how slip has changed through time provides insight about paleo-ground rupture activity on the Wellington Fault, and may help to resolve its interaction with other upper-plate faults across the southern North Island in accommodating deformation at the Hikurangi subduction margin.

\subsection{Background}

\subsubsection{The Wellington Fault}

The Wellington Fault is a northeast-striking, predominantly strike-slip (dextral) fault which extends from Cook Strait (between the North and South Islands), through Wellington and beyond. In the southern North Island, the Wellington Fault consist of three morphotectonic sections - from south to north they are the Wellington-Hutt Valley (WHV) segment (after Berryman, 1990), the Tararua section and the Pahiatua section (Langridge et al., 2005). The fault continues as the Ruahine and Mohaka faults in the central North Island, and further towards the Bay of Plenty as the Whakatane Fault, spanning a total distance of over $450 \mathrm{~km}$ (Beanland, 1995) (Fig. 2.1 a). This investigation focuses on the southernmost, WHV segment of the Wellington Fault. This section extends over a distance of $\sim 80 \mathrm{~km}$ between Cook Strait, where it has been mapped offshore (e.g. Pondard and Barnes, 2010), to the Kaitoke Basin where the fault undergoes a $2 \mathrm{~km}$ wide releasing side-step at its junction with the Tararua section (Fig. $2.1 \mathrm{~b})$.

The southernmost Wellington Fault generally bounds upthrown terrain on its northwest side, with Wellington Harbour and the Hutt Valley basin on the southeastern side (Begg and Mazengarb, 1996). Previous investigations (Begg and Mazengarb, 1996; Berryman, 1990; Gross et al., 2004; Langridge et al., 2009; Little et al., 2010) have shown that the fault dips steeply at $>70^{\circ} \mathrm{NW}$ to SE and may extend to the subduction interface. Consistent values of single-event displacement (3.2-4.7 m) for the last 5 events observed at Te Marua (see Fig. 2.1 b), led Berryman (1990) to suggest that the fault behaves in a characteristic manner, whereby the entire segment ruptures during a single event. This inference was consistent with an investigation by Van Dissen et al. (1992), which exposed similarly-timed paleo-ground rupture events from three different sites along the fault. From recently revised single-event displacement measurements $(5.0 \pm 1.5 \mathrm{~m}(1 \sigma)$ for the last four surface rupture events) Little et al. (2010) infer an average moment magnitude of $\sim \mathrm{Mw} 7.5$; a result consistent with recent 
seismic hazard modelling (Stirling et al., 2012). Little et al. (2010) also calculated a mean recurrence interval for ground rupture earthquakes on the southernmost Wellington Fault of $\sim 610-1100$ years for the last $\sim 4.5 \mathrm{ka}$, which compares well to a recurrence interval of $\sim 715$ 1575 years for the same period derived from paleoseismology studies by Langridge et al. (2011).

a)

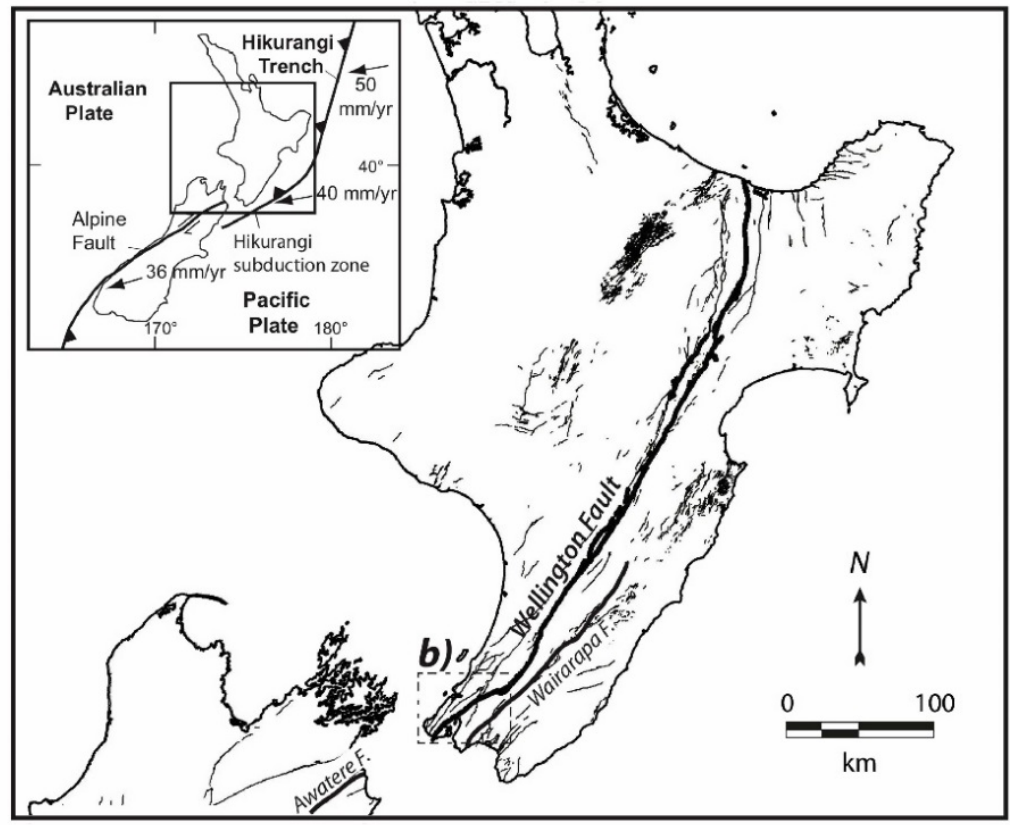

b)

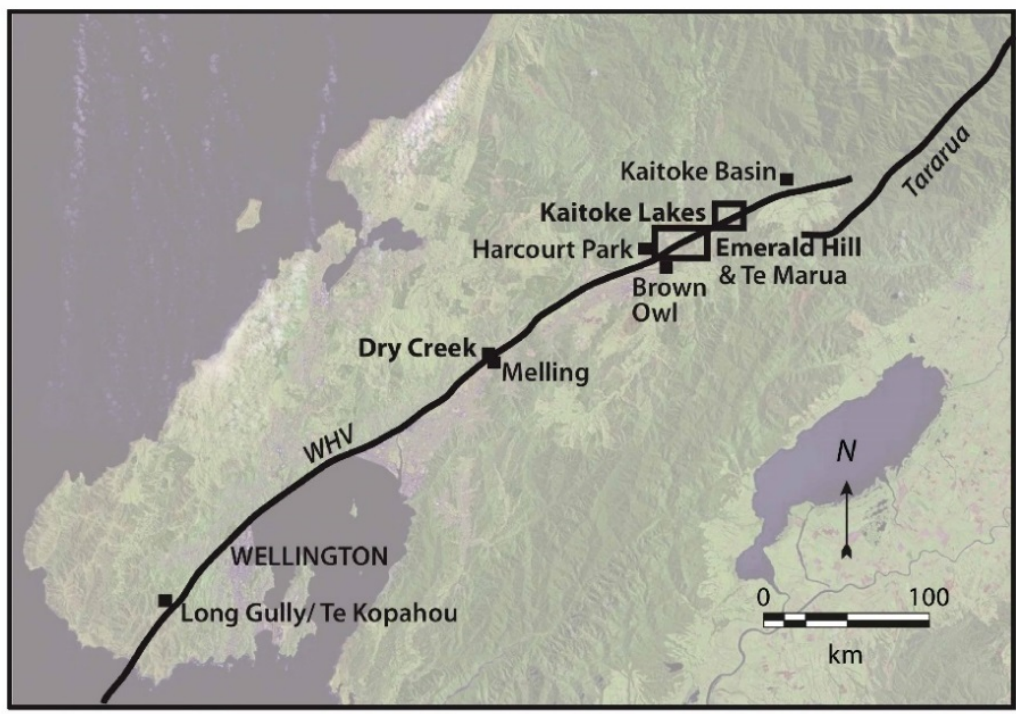

Figure 2.1. a) North Island of New Zealand, showing the Wellington Fault and its northern extensions. Inset - Tectonic setting of New Zealand; b) Map showing the Wellington Fault, including both the WellingtonHutt Valley (WHV) segment and the southernmost Tararua section. Also shown are sites referred to in this chapter - Emerald Hill, Te Marua, Brown Owl, Kaitoke Lakes, Dry Creek, Melling, Kaitoke Basin, Harcourt Park and Long Gully/Te Kopahou. 
The Wellington Fault offsets fluvial terraces at several sites along a $\sim 30 \mathrm{~km}$ stretch of the Hutt River, between Melling and Kaitoke Basin (e.g. Lensen, 1973; Berryman, 1990) (see Fig. 2.1 b). This study focuses on the terraces at Emerald Hill, about $35 \mathrm{~km}$ northeast of Wellington, and to a lesser extent on terraces from a site $\sim 4 \mathrm{~km}$ further northeast (upstream), at Stuart Macaskill Lakes near Kaitoke (hereafter referred to as Kaitoke Lakes). We also consider one terrace at Dry Creek, located approximately $15 \mathrm{~km}$ southwest (downstream) of Emerald Hill. The terrace deposits at these sites generally consist of fluvial gravels which are overlain by alluvial sands and silts deposited at the time of terrace abandonment (or soon after, for instance during flooding events). Older terraces are, in turn, overlain by aeolian silts (loess), presumably deposited during subsequent periods of cold climate (glacial/stadial) (Eden \& Hammond, 2003, and references therein).

At Emerald Hill, 12 terraces $\sim 5-70 \mathrm{~m}$ above the current-day river have formed in a meander encircling a local high (Emerald Hill, $204 \mathrm{~m}$ above mean sea level). Where they are cut by the Wellington Fault, the differential displacement of these terraces provides evidence of progressive slip on the fault for the last $\sim 100 \mathrm{ka}$, during time increments ranging from $\sim 1 \mathrm{ka}$ to up to $\sim 50 \mathrm{ka}$. At Kaitoke Lakes, 5 fault-displaced terraces occupy the south eastern side of the river, the oldest of which, currently $\sim 40 \mathrm{~m}$ above the river, was abandoned around $\sim 20 \mathrm{ka}$ ago. Although terrace offsets at Emerald Hill and Kaitoke Lakes have been described previously (Lensen, 1973; Berryman, 1990; Grapes, 1993), detailed maps of these displacements have not been presented before, nor have any of the terraces been radiometrically dated. Today, the terraces have been anthropogenically modified - at Emerald Hill due to suburban development, and at Kaitoke Lakes due to the construction of water collection and supply lakes for the Wellington municipality. We therefore employ pre-development aerial photographs to reconstruct the original topography at key displacement localities.

\subsubsection{Review of Previous Wellington Fault Slip Estimates}

Terrace displacements at three sites along the Hutt River, including Emerald Hill, were first depicted in simple diagrammatic form by Lensen (1973). In subsequent investigations, authors attempted to measure terrace offsets as well as estimate terrace ages (Berryman, 1990; Grapes, 1993). Based on the assumption that all terrace sequences throughout the southern North Island formed simultaneously, Berryman (1990) estimated the ages of the aggradational terraces at Emerald Hill by correlating them to other, better-dated terraces in the Manawatu catchment, which had been investigated by Milne (1973). Milne (1973) had applied tephrochronology and the timing of global glacial/interglacial cycles to assign ages to aggradational terraces along the 
Rangitikei River. Berryman (1990) measured terrace riser displacements at Emerald Hill using a combination of tape-measure, scaling from aerial photographs and topographic survey methods available at the time. His displacement calculations for each terrace incorporated both the horizontal offset of the terrace risers and tread width differences for the terraces across the fault (similar to the intermediate or upper terrace reconstruction method described by Cowgill (2007)). Berryman (1990) calculated an average slip rate for the Wellington Fault of 6.0-7.6 $\mathrm{mm} / \mathrm{yr}$ since $\sim 140 \mathrm{ka}$. Grapes (1993) reported exposures of the Kawakawa tephra (currently thought to have an age of $25 \mathrm{ka}$ (Vandergoes et al., 2013)) at Emerald Hill, within loess deposits overlying what Berryman (1990) had identified as a degradational terrace $<15 \mathrm{ka}$ old. Grapes (1993) also questioned the technique by which the fault-displacements had previously been calculated. Based on a different set of terrace age correlations and displacement estimates of terrace riser offsets, Grapes (1993) estimated a dextral slip rate of 4.1-5.1 mm/yr since $\sim 140$ ka.

More recently, Little et al. (2010) studied a sequence of 13 Holocene to late Pleistocene-aged terraces directly across the Hutt River from Emerald Hill, at Te Marua. Their displacement and age estimates, measured from GPS-based microtopographic data and 18 OSL ages from eight sampled terraces, indicate a minimum dextral slip rate for the Wellington Fault of $4.5 \pm 0.4$ $\mathrm{mm} / \mathrm{yr}$ and a maximum of $8.2 \mathrm{~mm} / \mathrm{yr}$ for the last $\sim 4 \mathrm{ka}$. Little et al. (2010) also presented evidence for a mean single-event displacement of $5.0 \pm 1.5 \mathrm{~m}(1 \sigma)$ during the last four groundrupturing earthquakes, since $4.5 \pm 0.4 \mathrm{ka}$.

\subsection{Approach}

\subsubsection{Terrace Nomenclature}

We have re-named the terraces at Emerald Hill and Kaitoke Lakes to dissociate them from any previous interpretation of the stadial period during which they may have formed. From youngest (lowest in elevation) to oldest (highest in elevation) we name the fault displaced terraces EH-T1 to EH-T6. We also discuss one terrace in the Emerald Hill sequence which is not offset by the Wellington Fault (because it is located away from the fault) - this terrace has been named EH-T1a to accord with its geographic position between EH-T1 and EH-T2. The terraces at Kaitoke Lakes have been named in a similar fashion, except using the prefix 'KL'. The nearby Te Marua terraces, investigated by Little et al. (2010), are referred to using the prefix 'TM'. As we only discuss one terrace from each of the Brown Owl and Dry Creek sites, we refer to these simply as the Brown Owl and Dry Creek terraces. 


\subsubsection{Measuring Fault Displacement}

In this section, we briefly describe the concept behind measuring displacement from fault-offset terraces, including terrace types, their attributes and associated terminology. We also describe how topographic data were created from vertical aerial photographs and the assumptions and methods we applied when measuring terrace displacement.

Where displaced by a fault, a linear geologic or geomorphic feature, such as a terrace riser, defines two piercing points along the fault from which fault slip, both vertical and horizontal, can be measured (Fig. 2.2). Fluvial terraces can be aggradational (fill, formed by deposition) or degradational (cut or strath, formed by erosion). A terrace riser is an ancient, now abandoned, subvertical riverbank that forms by incision as the river downcuts into terrace deposits, forming a new floodplain at a lower elevation. Within a sequence, therefore, terraces are progressively younger with decreasing elevation.

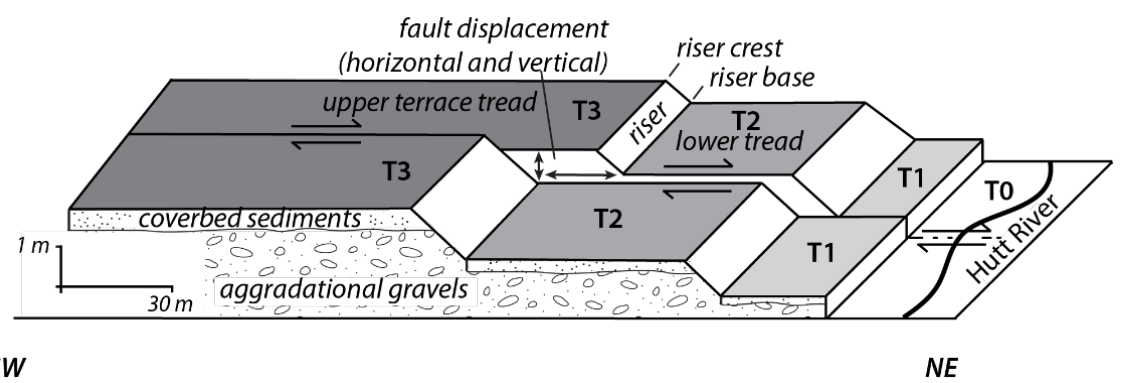

Figure 2.2. Schematic block diagram showing basic geometric features of fault-displaced terrace risers. Figure depicts true dextral offsets of risers between EH-T1 (equivalent to T1 in figure) and EH-T3 (equivalent to T3) at Emerald Hill. Thickness of coverbed and gravel deposits are illustrative only - they do not represent true thickness.

Because many of the original terraces occupying Emerald Hill and Kaitoke Lakes have been destroyed over the last few decades due to suburban development, our investigation relied on archival aerial photographs from the year 1942. At Kaitoke Lakes, terrace offsets were quantified by scaling of orthorectified historic air photos. At Emerald Hill, we employed a photogrammetric analysis of pre-development, archival vertical aerial photographs, undertaken by New Zealand Aerial Mapping Ltd. Their methods are briefly described as follows. First, aerial triangulation was performed on vertical aerial photos covering Emerald Hill (New Zealand Aerial Mapping, Run 322 Photos 27-29, Scale 1:16,000). Image matching (performed by BAE Socet Set software) was used to identify 'tie points' (i.e. points common to the adjacent 
and overlapping aerial photos), thus creating a photographic 'block'. To orient the photographic 'block' (using Leica ORIMA software), we provided New Zealand Aerial Mapping Ltd. with a ground co-ordinate system. This consisted of 9 control points over a $4 \mathrm{~km}^{2}$ area, chosen at sites which were precisely located on both historical photos and current day aerial images, and surveyed using a real-time kinematic global positioning system (RTK GPS). A terrain model was extracted and edited manually (using BAE Socet Set software) to ensure correct correlation with the ground surface. The result of this photogrammetric processing was new digital topographic data, which we gridded at a $5 \mathrm{~m}$ spacing, and contoured at $50 \mathrm{~cm}$ vertical intervals (using MapInfo Vertical Mapper software) (Fig. 2.3). These paleotopographic data were the basis for our identifying and mapping of the terraces at Emerald Hill.

For this study, we assume that each terrace riser had been completely trimmed by the river prior to its abandonment, and that fault-displacement of the riser began to accumulate only after this time. Cowgill (2007) describes a series of geomorphic indices to determine the most appropriate method of terrace reconstruction. For a case of complete trimming, any abandoned channel on the terrace tread below the offset terrace riser (lower terrace, see Fig. 2.2) should be displaced by the same amount as the back riser of that terrace. Although no mappable channels remain on the terraces at our sites to test this theory, Little et al. (2010) have shown that several offset abandoned channels comply with this complete-trimming scenario on similar-aged terraces on the opposite side of the Hutt River to our study. In further support, we note that the present day river appears to have more than enough erosive power to trim the unconsolidated gravel exposed in the riverbank, as the fault trace today does not offset the modern riverbanks.

Following abandonment, the crest of a terrace riser may be further eroded (e.g. by wind or sheetwash), whereas the base of the riser may become buried by colluvial material shed from above. We therefore measured fault displacement relative to an arbitrary topographic contour near the middle of the riser. Following Little et al. (2010), we first calculated the vertical displacement or 'throw' of the terrace by averaging $>170$ (maximum 850 ) elevation points for each side of the fault. These points were chosen from unmodified areas of the tread near the fault scarp, thereby minimising apparent differences in elevation of the terrace across the fault due to any possible natural sloping of the tread. The throw was determined from the difference in elevation of the same terrace tread on either side of the fault. An arbitrary topographic contour was then chosen near the mid-point of the riser on one side of the fault and the calculated throw was applied to identify the once-equivalent paleo-contour of the corresponding riser on the opposite side of the fault. 


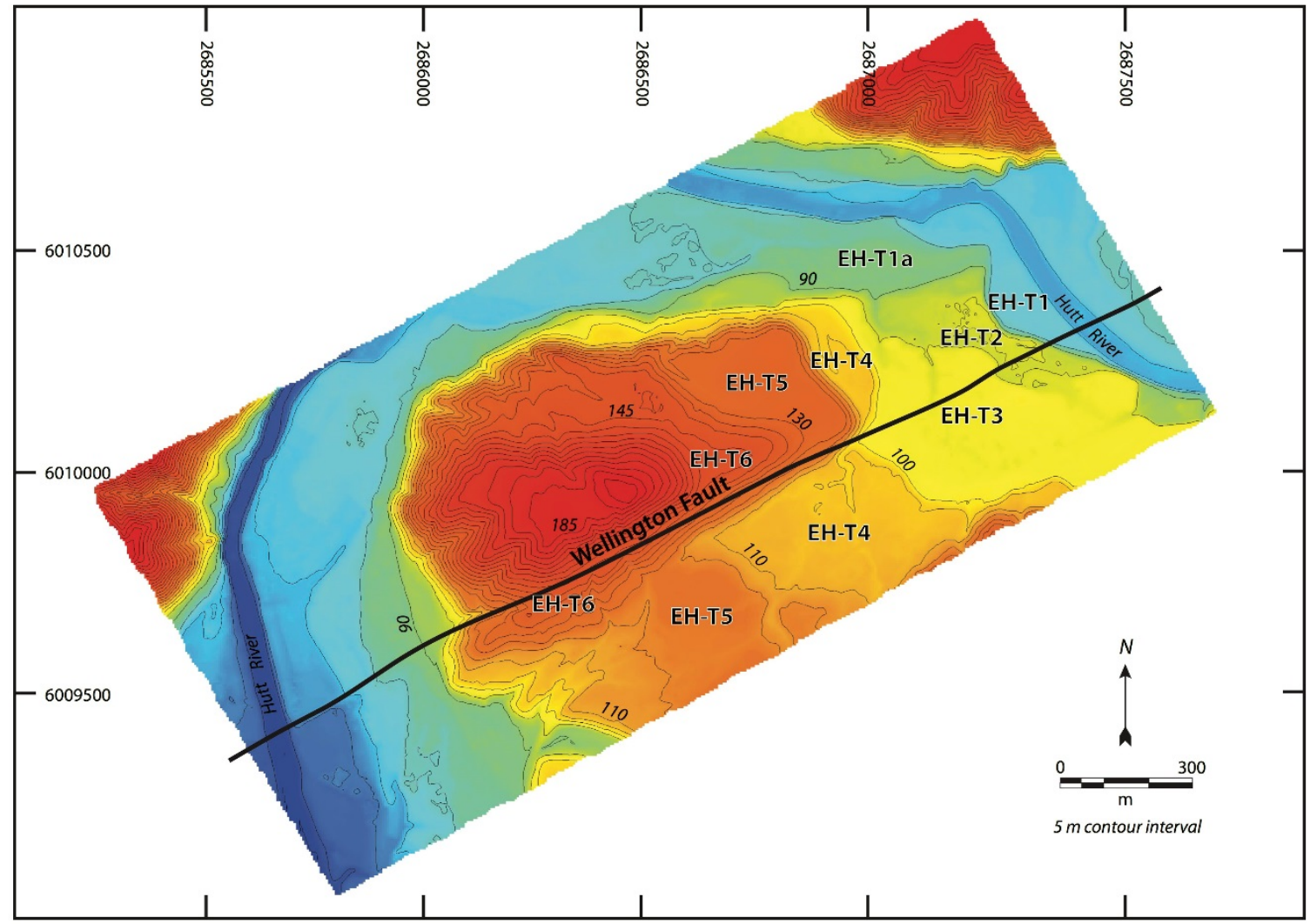

Figure 2.3. Digital topographic model of the Emerald Hill region, based on elevation data created from photogrammetric processing of historic aerial photography. The Wellington Fault is also shown (solid black line). Topographic contours on this simplified map are at $5 \mathrm{~m}$ intervals, elevation is relative to mean sea level. Grid marks are New Zealand Map Grid (lee, 1978) (Geodetic Datum 1949) eastings and northings (meters).

To measure the displacement of the riser, the fault proximal segments of the once continuous mid-riser contour lines were projected across an intervening corridor of scarp-related modified topography to the fault plane. This was done in two alternate ways: as linear and as uniformly curved projections (Fig. 2.4). The linear projection method, after Little et al. (1998) and Mason et al. (2006), extends the fault proximal segment of each mid-riser contour line to the fault plane with a trend that is the average of the mid-riser paleo-contour lines within 10-20 m of the scarp. We assume that the riser segments once had an identical azimuth on both sides of the fault trace, therefore any deflection of either one of the risers necessary to comply with an identical azimuth at the fault would fall within a triangular area, the sides of which are parallel to the riser projection used on each side of the fault. We consider the projected triangle bounds to be the extreme positions that the riser could have occupied at the fault to no less than the $2 \sigma$ confidence interval. In reality, it is more likely that the change in riser orientation across the now scarp-modified topography was gradual rather than abrupt and kink-like, involving instead 
a gentle curvature on both sides of the fault. To represent this, we employ a non-linear projection method, which considers the orientation of both riser segments and tangent lines to each, and then calculates a uniformly curved (circular arc) projection across the scarp-modified region. The curvatures of each of the projected risers are thus the same on either side of the fault, resulting in a coincidence of riser trends at the fault trace. We consider these curved projections to be more realistic representations of a riser's position prior to displacement. References to preferred terrace displacements presented herein are based on this curved projection measured at the fault plane, whereas the uncertainty values (maximum and minimum, $2 \sigma$ ) are determined more conservatively from the linear projections (abrupt, end member cases of curved distribution) (see Fig. 2.4).

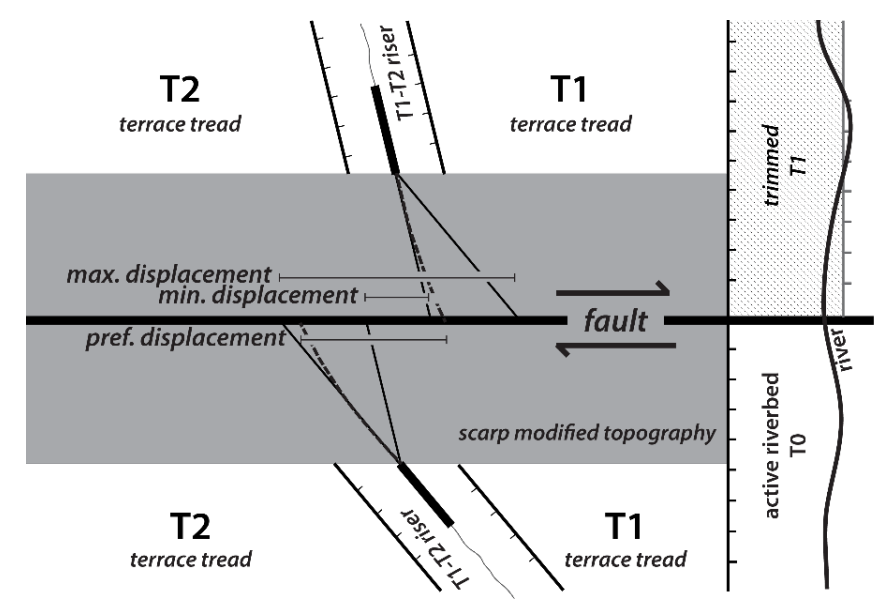

Figure 2.4. Schematic diagram showing fault-offset hypothetical terraces $\mathrm{T} 1$ and $\mathrm{T} 2$ and associated terrace risers. Grey rectangle represents the region of scarp modified topography. Figure depicts the complete trimming scenario assumed for terraces in this study. The maximum, minimum and preferred terrace displacement distances, as defined in this investigation, are shown.

\subsubsection{Determining Terrace Ages}

As stated previously, we infer that fault displacement began to accumulate on a terrace riser only after the tread beneath had been abandoned by the river. We collected samples for OSL analysis from coverbeds directly overlying the fluvial gravels, wherever possible, in an attempt to date the timing of abandonment of the terrace. Samples were also collected from within the underlying gravel sequence as well as from any overlying loess, providing maximum and minimum age constraints, respectively, for the timing of abandonment of the now faultdisplaced terrace surface. 
In total, 19 samples of silt/fine sand were collected, targeting the 4-11 $\mu \mathrm{m}$ grain size fraction. Sample preparation and analysis was undertaken by the Luminescence Dating Facility at Victoria University of Wellington. All samples were analysed using the Multiple Aliquot Additive Dose technique (MAAD) (Aitken and Xie, 1992; Lang and Wagner, 1997). To achieve higher accuracy for older samples, or when MAAD data were scattered, we applied the Single Aliquot Regenerative (SAR) method (Murray and Wintle, 2000). Further details regarding the OSL analysis of the samples are provided in Appendix $A$ of this Thesis.

In addition to our new OSL ages, we have also considered OSL ages of Holocene terraces across the Hutt River, at Te Marua from Little et al. (2010). In determining the age of a terrace, we also consider its relative geomorphic age based on its vertical position within the terrace sequence; terrace age must increase with relative elevation above the river. In addition, we consider the thickness and composition (namely, the number of loess units) of the coverbed stratigraphy. We use the geomorphology and geology as outlined above to model betterconstrained terrace abandonment ages. This is discussed in more detail in 'Additional Terrace Age Constraints - Terrace Abandonment Ages'.

We conclude the age of abandonment of the terrace tread below a riser is representative of when the riser was last trimmed for degradational terraces in particular, whose risers form when the river downcuts into the landscape. Risers between aggradational terraces may have a more complicated history of trimming; they are formed when the river first cuts into the aggradational gravels of the upper terrace, but they may or may not be trimmed again during the period of aggradation which forms the lower terrace. We discuss this matter in more detail in 'Additional Terrace Age Constraints - Aggradational vs. Degradational Terrace Riser Trimming'.

\subsection{Results}

\subsubsection{Terrace Displacements and Ages}

We here present our detailed topographic maps of fault-offset terrace risers, as well as our displacement and age data for the fluvial terraces at Emerald Hill and Kaitoke Lakes. All displacement measurements are stated to $2 \sigma$. A summary of fault offsets, including those from previous studies, is provided in Table 2A. Only those OSL ages most relevant to determining the timing of abandonment of each terrace are discussed in the accompanying text; however, the complete list of terrace OSL age results, as well as age estimates from previous studies, are summarised in Table $2 \mathrm{~B}$. We quote all OSL ages to $2 \sigma$ in accordance with the level of our 
quoted displacement errors. Further details of our OSL analysis are provided in Appendix A of this thesis and OSL sample descriptions are presented within stratigraphic logs in Appendix $B$.

\subsubsection{Emerald Hill}

At Emerald Hill (Fig. 2.5), equal numbers of terrace risers abut the Wellington Fault on both sides of the fault, and the two youngest terraces, EH-T1 and EH-T2, have a comparable elevation ( $\leq 20 \mathrm{~cm}$ difference) across the fault. We therefore infer that the first riser back from the river on the northern side is paired with the first riser back from the river on the southern side, and the second riser from the river on the north is paired to the second on the south, and so on.

The oldest fault-offset terrace riser at Emerald Hill is EH-T5-T6 (Fig. 2.6a). This riser, and the EH-T5 and EH-T6 terrace treads below and above, are best defined on the northern, upthrown side of the fault; south of the fault they are poorly preserved. South of the fault, we assume an originally nearly level surface, $\sim 10 \mathrm{~m}$ higher in elevation than EH-T5, to be a remnant of the EH-T6 tread, and infer that the southern riser segment lies somewhere between these two terrace treads. Due to the poor preservation of these features on the southern side of the fault, in this instance we did not employ any formal riser projection method to measure fault-offset. Instead, we defined a series of alternative possible piercing points on both sides of the fault from which we estimated a maximum and minimum fault displacement. These points were taken at the crest and base of the riser on the northern side of the fault, and at equivalent points on the southern side of the fault. Based on our interpretation of the topography, we identified one location for the EH-T5-T6 riser crest on the southern side of the fault, but infer two alternative extreme possible locations for the base of that riser - these are shown as ' $A$ ' and ' $B$ ' in Fig. 6a. In the location ' $A$ ' scenario, the riser is about the same height ( $\sim 10 \mathrm{~m})$ and has about the same slope near to the fault on both the southern and northern sides. The difference in EH-T5 tread width across the fault is about $100 \mathrm{~m}$ (wider on the southern side). In this scenario, an apron of scarp-derived colluvium is inferred to abut the foot of the southern riser. In the alternative ' $\mathrm{B}$ ' scenario, the previously interpreted 'apron of colluvium' is instead inferred to be an extension of the riser and there is little difference in tread width of EH-T5 across the fault. For this to be the case, there would have to have been no dextral-slip ground rupture between the abandonment of terrace EH-T6 and EH-T5. We therefore prefer scenario ' $A$ ' for the location of the base of the southern EH-T5-T6 riser, where the slope of the southern riser is more compatible with the northern riser segment, and the change in EH-T5 terrace tread width across the fault is consistent with the sense of slip on the Wellington Fault. Measuring the average displacement between the southern and northern riser crest $(571 \mathrm{~m})$, and southern 
and northern riser base $(601 \mathrm{~m})$ yields a preferred displacement estimate of $586 \pm 15 \mathrm{~m} . \mathrm{In}$ contrast, the 'B' scenario gives a displacement of $510 \pm 60 \mathrm{~m}$. The EH-T5 terrace tread has been vertically displaced by $\sim 10.3 \mathrm{~m}$, upthrown to the north.

We augered terrace EH-T5 at two sites north of the fault scarp (sample sites 'COW' and 'VERGE' in Fig. 2.5). At both sites, the auger intersected a silt-dominated sequence of sediments to a depth of 310-340 cm before reaching fluvial gravels (Fig. $2.7 \mathrm{a}$, b). Changes in colour and grain size suggest that 3 loess units make up the coverbed sequence of this terrace. A total of four samples (COW 125, 210, 293 and VERGE 327) were collected. The corresponding OSL ages occur in correct sequential order, i.e. increasing in age with depth, ranging from $24.8 \pm 2.9 \mathrm{ka}$ at $125 \mathrm{~cm}$ depth to $93.2 \pm 19.6 \mathrm{ka}$ at $327 \mathrm{~cm}$ depth. The oldest age obtained from EH-T5, collected from sandy silt $11 \mathrm{~cm}$ above the fluvial gravels, provides a minimum age of the timing of terrace abandonment of $93.2 \pm 19.6 \mathrm{ka}$.

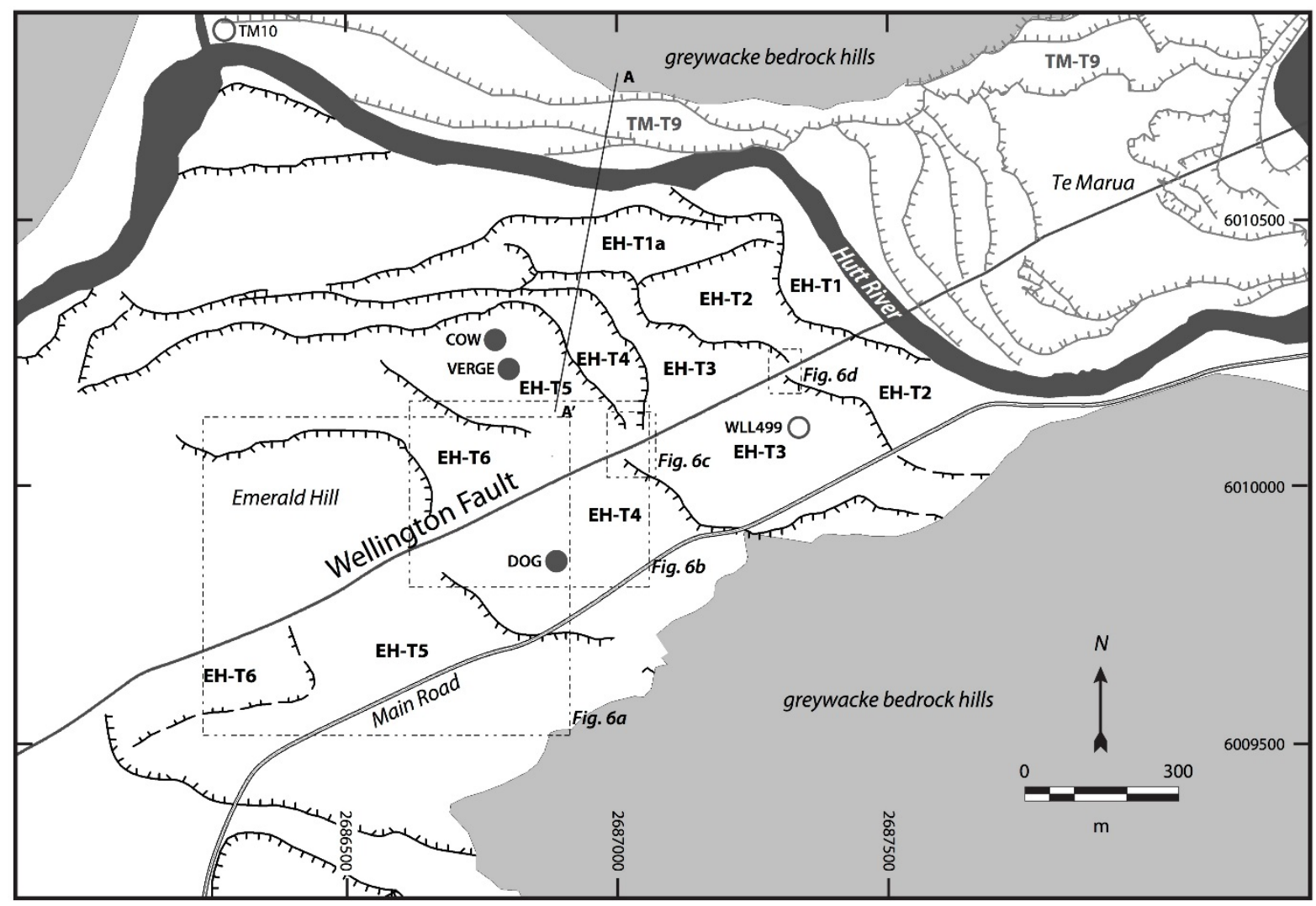

Figure 2.5. Simplified map of terraces at Emerald Hill (black) and Te Marua (grey - after Little et al., 2010) showing OSL sample collection sites (open circles) and auger sites (solid circles). Figure also shows location of terrace riser offsets presented in Fig. 6 a-d (dashed squares), as well as profile A-A' of Fig. 8b. Hutt River flows from east to west. Grid marks are New Zealand Map Grid (Lee, 1978) (Geodetic Datum 1949) eastings and northings (meters). 

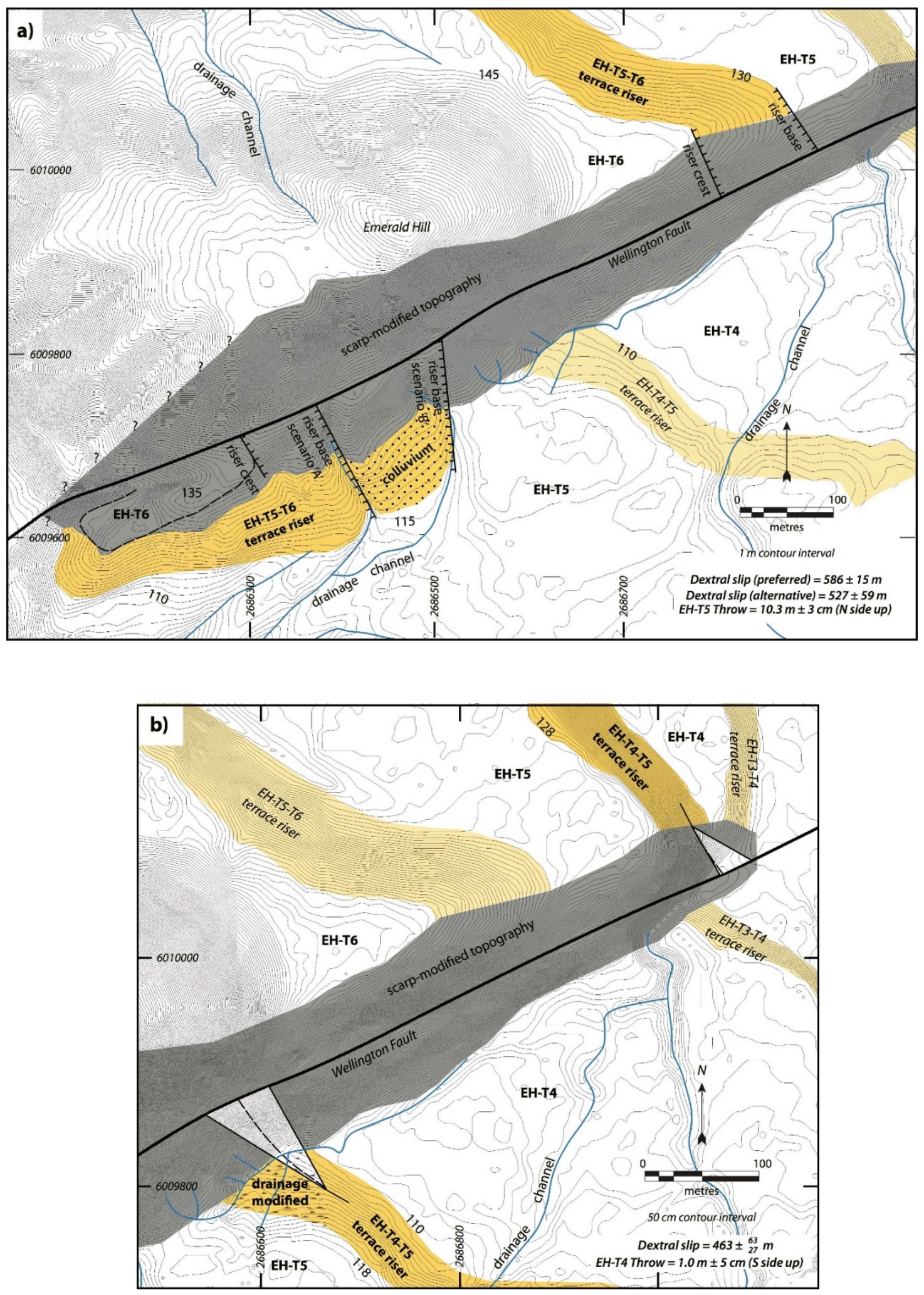

Figure 2.6. Topographic maps of fault-offset risers along the Wellington Fault for risers a) EH-T5-T6; b) EH-T4-T5; c) EH-T3-T4; and d) EH-T2-T3 at Emerald Hill. For significance of scenarios A and B in Fig. 6a see 'Terrace Displacements and Ages'. For all except Fig. 6a, mid-riser projections are shown in solid (linear) and dashed (curved). Elevation data is based on photogrammetric processing of historic aerial photography. Elevations are in metres, relative to mean sea level. Grid marks are New Zealand Map Grid (Lee, 1978) (Geodetic Datum 1949) eastings and northings (metres). 

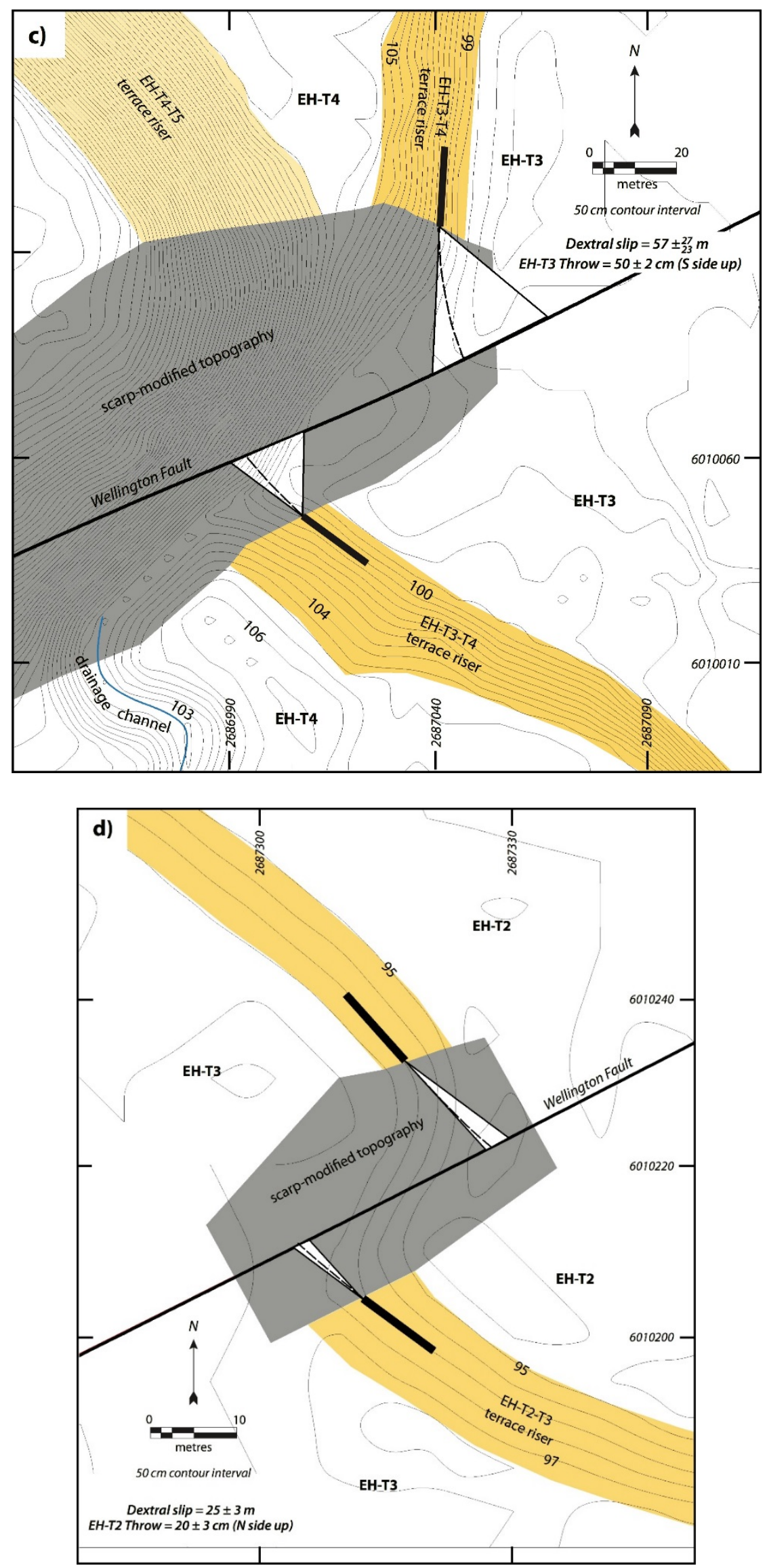

Figure 2.6. Continued 
In a much more straight-forward manner, we measured a dextral displacement for the wellpreserved EH-T4-T5 riser of $463 \pm{ }_{27}^{63} \mathrm{~m}$ (Fig. $2.6 \mathrm{~b}$ ). The EH-T4 tread is $\sim 30 \mathrm{~m}$ above the Hutt River level. Differences in tread elevation across the fault suggest that EH-T4 has been upthrown to the south by $\sim 1 \mathrm{~m}$. This terrace was augered on the southern side of the fault (sample site 'DOG' in Fig. 5), exposing a silt-dominated sequence to a depth of $\sim 470 \mathrm{~cm}$, followed by a sandy sequence to a depth of $\sim 680 \mathrm{~cm}$ (Fig. $2.7 \mathrm{a}, \mathrm{c}$ ). At this last depth, fluvial gravels had still not been intersected by the auger. The upper silt sequence is interpreted to consist of 2 loess units, distinguishable mainly through a change in sediment colour. In all, seven samples were collected; four samples from within the silt (DOG 110, 155, 295, 420), and three from the underlying sand deposits (DOG 484, 552, 684). The ages obtained from the silt deposits are in stratigraphic order, ranging from $17.2 \pm 2.7 \mathrm{ka}$ at a depth of $110 \mathrm{~cm}$, to $38.3 \pm$ $3.1 \mathrm{ka}$ at a depth of $420 \mathrm{~cm}$, the latter having been collected from $\sim 60 \mathrm{~cm}$ above the silt/sand contact. The ages obtained from within the underlying sand deposits are within error of one another, providing a pooled estimate for their age of deposition of $72.3 \pm 8.8 \mathrm{ka}$. We interpret that these sandy sediments were deposited at the same time as the fluvial gravels elsewhere in the EH-T4 terrace sequence, with the auger site perhaps being an area of localised channel fill or overbank deposition. To confirm that the sand deposits were co-depositional with the EHT4 fluvial gravels, we verified the thickness of the EH-T4 coverbeds as exposed along the EHT3-T4 terrace riser. At the riser, the coverbeds are everywhere $\leq 5 \mathrm{~m}$ thick and are directly underlain by gravels. Further, we surveyed the elevation of the gravel sequence along the riser using RTK GPS; their elevation is equivalent to the elevation of the sands intersected in the auger hole.

Berryman (1990) identified another site where he interpreted EH-T4-equivalent deposits were preserved, $700 \mathrm{~m}$ south of Emerald Hill at Brown Owl (see Fig. 2.1b). We collected a silt sample (WLL482) at this location, $\sim 10 \mathrm{~cm}$ above the gravel strath as exposed in a road-cutting. This sample yielded a minimum age of abandonment for this terrace remnant of $95.4 \pm 18.4 \mathrm{ka}$ - older than the pooled age obtained from within EH-T4 terrace fluvial sands (i.e. older than their age of deposition). This terrace remnant at Brown Owl is not continuously traceable to the faulted EH-T4, so we surveyed an elevation profile using RTK GPS to help evaluate whether they are indeed the same terrace (Fig. 2.8 a). Based only on elevation above the Hutt River, the terrace remnant at Brown Owl is indistinguishable from EH-T4 at Emerald Hill. Despite this, we have chosen to reject the age from Brown Owl as being representative of the age of abandonment of EH-T4 for the following reasons: i) the OSL age from Brown Owl relates to a terrace remnant not continuously identifiable to the EH-T4 terrace as mapped 
alongside the Wellington Fault; and ii) only one age was obtained from the Brown Owl terrace, with no other samples to support this sole age, as compared to 7 stratigraphically-consistent ages collected from EH-T4. It may be that the OSL data from Brown Owl is unreliable, or the Brown Owl terrace may be a remnant of another terrace which formed at a different time to EH-T4, and which is not preserved alongside the Wellington Fault at Emerald Hill.

We measured the dextral displacement of the EH-T3-T4 riser as $57 \pm_{23}^{27} \mathrm{~m}$ (Fig. $2.6 \mathrm{c}$ ). The large error of this displacement estimate is a result of the significant change in riser trend across the fault. The elevation of the EH-T3 tread is $\sim 20 \mathrm{~m}$ above the river, with a vertical offset of $\sim 50 \mathrm{~cm}$, upthrown to the south. This terrace was augered on the southern side of the fault (see Fig. 2.5), intersecting silt before reaching fluvial gravels at a depth of $\sim 50 \mathrm{~cm}$. A silt sample (WLL499) collected within $15 \mathrm{~cm}$ of the gravels yields a minimum age of abandonment for EH-T3 of $8.5 \pm 1.7 \mathrm{ka}$.

Table 2A. Terrace Offsets
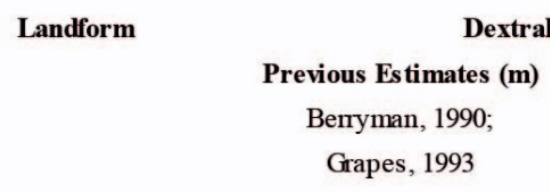

Grapes, 1993

Dextral Displacement

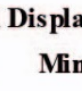

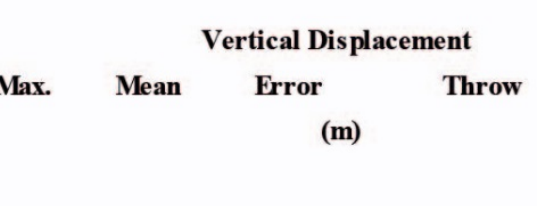

Emerald Hill
EH-T1 Tread
EH-T1-T2 Riser
EH-T2 Tread
EH-T2-T3 Riser
EH-T3 Tread
EH-T3-T4 Riser
EH-T4 Tread
EH-T4-T5 Riser
EH-T5 Tread
EH-T5-T6 Riser
EH-T6 Tread
Kaitoke Lakes
KL-T3-T4 Riser
Dry Creek
Dry Creek Terrace Tread

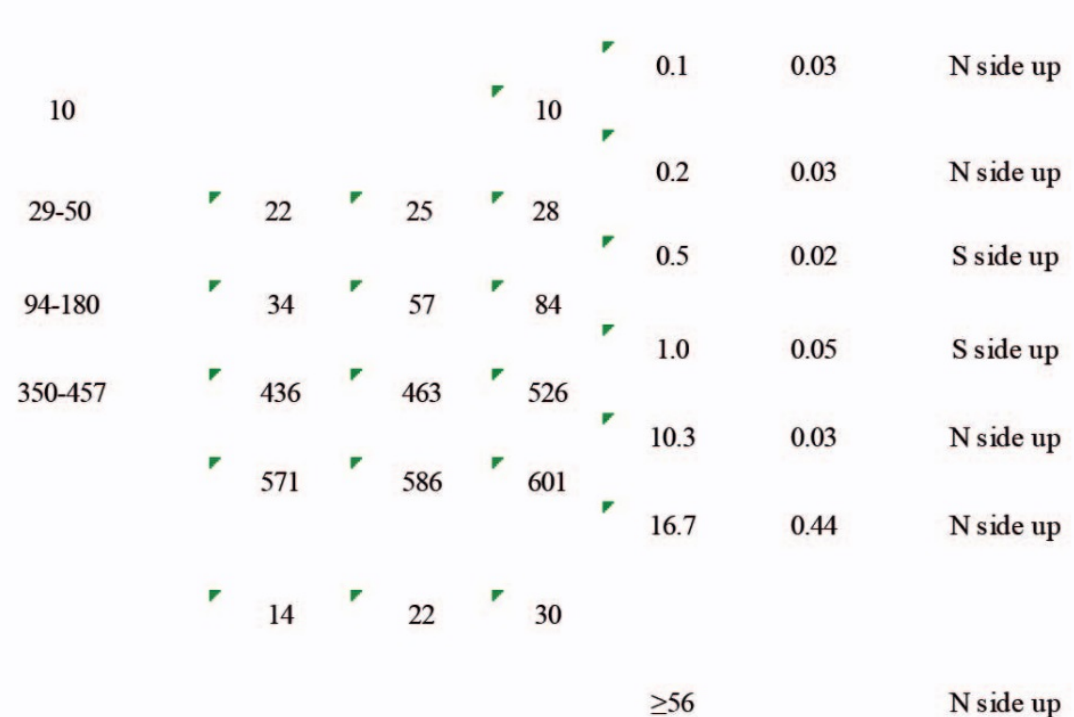

Preferred fault dextral displacement estimates are based on curved projections; displacement Min. and Max. estimates are based on linear projections $(2 \sigma)$ - see 'Approach - Measuring Fault Displacement' for more details. 
We estimate the dextral displacement of the EH-T2-T3 riser as being $25 \pm 3 \mathrm{~m}$ (Fig. $2.6 \mathrm{~d}$ ). The EH-T2 terrace tread is $\sim 18 \mathrm{~m}$ above the Hutt River, and there is a vertical offset across the fault of approximately $\sim 20 \mathrm{~cm}$, upthrown to the north. Due to a lack of suitable sampling sites, no OSL samples were collected from the EH-T2 terrace.

Using a series of river-perpendicular profiles (e.g. A-A' in Fig. 2.5, Fig. 2.8 b), we identified a terrace at Emerald Hill which can be topographically matched to a terrace with the same elevation on the opposite side of the Hutt River ( $200 \mathrm{~m}$ away), at Te Marua. This terrace, EHT1a, is $\sim 5 \mathrm{~m}$ lower in elevation than EH-T2 at Emerald Hill. At Te Marua, the terrace equivalent to EH-T1a has been identified as 'T9' (from Little et al., 2010) but is referred to here as TMT9. An OSL sample (TM10) collected from the silty coverbeds of TM-T9 (see Fig. 2.5), 25 $\mathrm{cm}$ above fluvial gravels, yielded an age of $9.6 \pm 1.6 \mathrm{ka}$ (see Little et al., 2010 for a stratigraphic description). Although EH-T1a is not intersected by the Wellington Fault, it must post-date the abandonment of terrace EH-T2 above it, and pre-date that of EH-T1 below, both of which are displaced by the fault.

The youngest fault-displaced terrace at Emerald Hill is EH-T1. The displacement of terrace riser EH-T1-T2 is still intact and a tape-measure estimate in the field yielded a dextral displacement of 6-10 $\mathrm{m}$ for this riser. According to the single-event displacement values of $5.0 \pm 1.5 \mathrm{~m}(1 \sigma)$ reported by Little et al. (2010) this displacement records the effects of the last 1-2 earthquake events. Analysis of the paleotopographic data indicates a vertical displacement of the EH-T1 terrace of $\sim 10 \mathrm{~cm}$, upthrown to the north. Although no samples were collected from EH-T1 for OSL analysis, this terrace is $\sim 5 \mathrm{~m}$ above the current-day river level, which is lower (and therefore younger) than TM-T6 on the other side of the river, dated by Little et al. (2010) to have a maximum age of $4.5 \pm 0.8 \mathrm{ka}$.

\subsubsection{Kaitoke Lakes}

At Kaitoke Lakes (Fig. 2.9), we measured displacement of the KL-T3-T4 riser, the upper and lower terraces of which are similar in elevation above the river as EH-T2, EH-T3 and EH-T4 at Emerald Hill, thus allowing comparison of fault displacement of terraces between these sites. The KL-T3-T4 terrace riser at Kaitoke Lakes, as identified from scaling of orthorectified historic air photos, is displaced dextrally by $22 \pm 8 \mathrm{~m}$ (Fig. 2.10). The KL-T4 terrace tread is $\sim 25-30 \mathrm{~m}$ above the river, while the KL-T3 tread is $\sim 15-20 \mathrm{~m}$ above the river. More precise terrace elevations, and the vertical offset of KL-T3 across the fault, are difficult to estimate as we lack photogrammetrically-derived digital elevation data depicting the original topography; a field measurement of current-day elevations would be unrepresentative because most of the 
a)

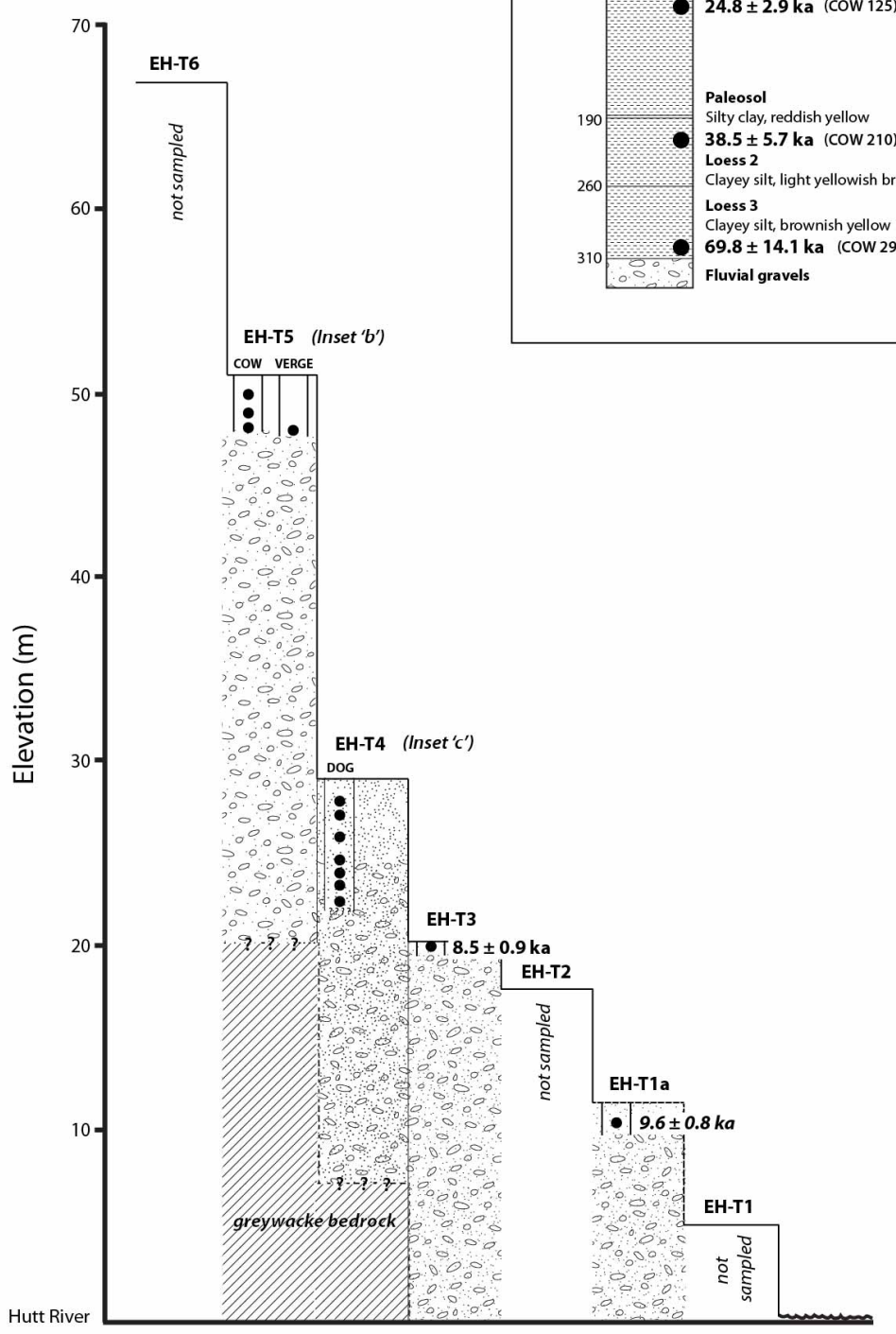

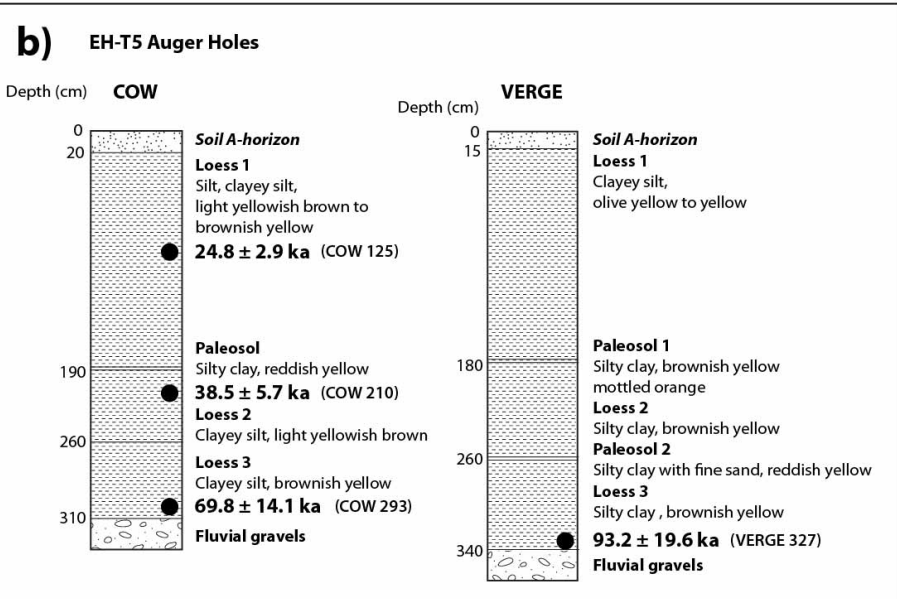

C) EHTT Auger Hole DOG

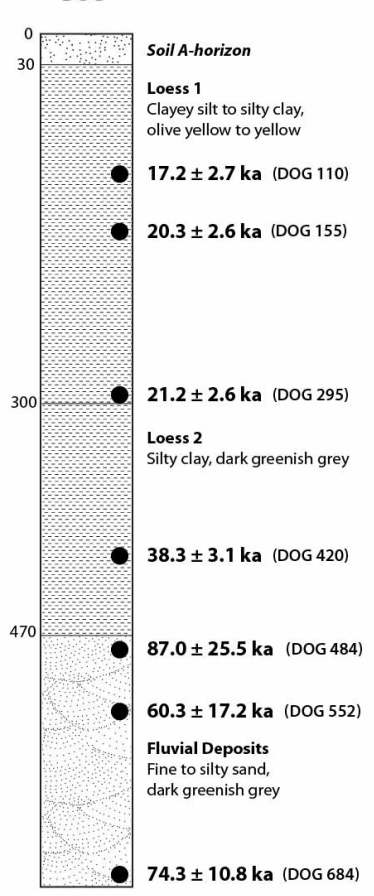

Figure 2.7. a) Schematic profile of fluvial terraces at Emerald Hill, showing the height of the main terraces (north of the fault) relative to the Hutt River. Plotted horizontal terrace widths do not represent true widths. Also shown are terrace stratigraphy and selected OSL results of sampled terraces. The approximate depths (from the terrace tread) at which samples were collected are plotted as black dots. Stratigraphic logs are shown for those terraces that were augered, namely b) EH-T5 (augered twice - 'COW' and 'VERGE' sites) and c) EH-T4 ('DOG' site). Locations of these auger holes are shown in Fig. 5. For a stratigraphic description of terrace EH-T1a (TM-T9 equivalent) see Little et. al. (2010). 
a)

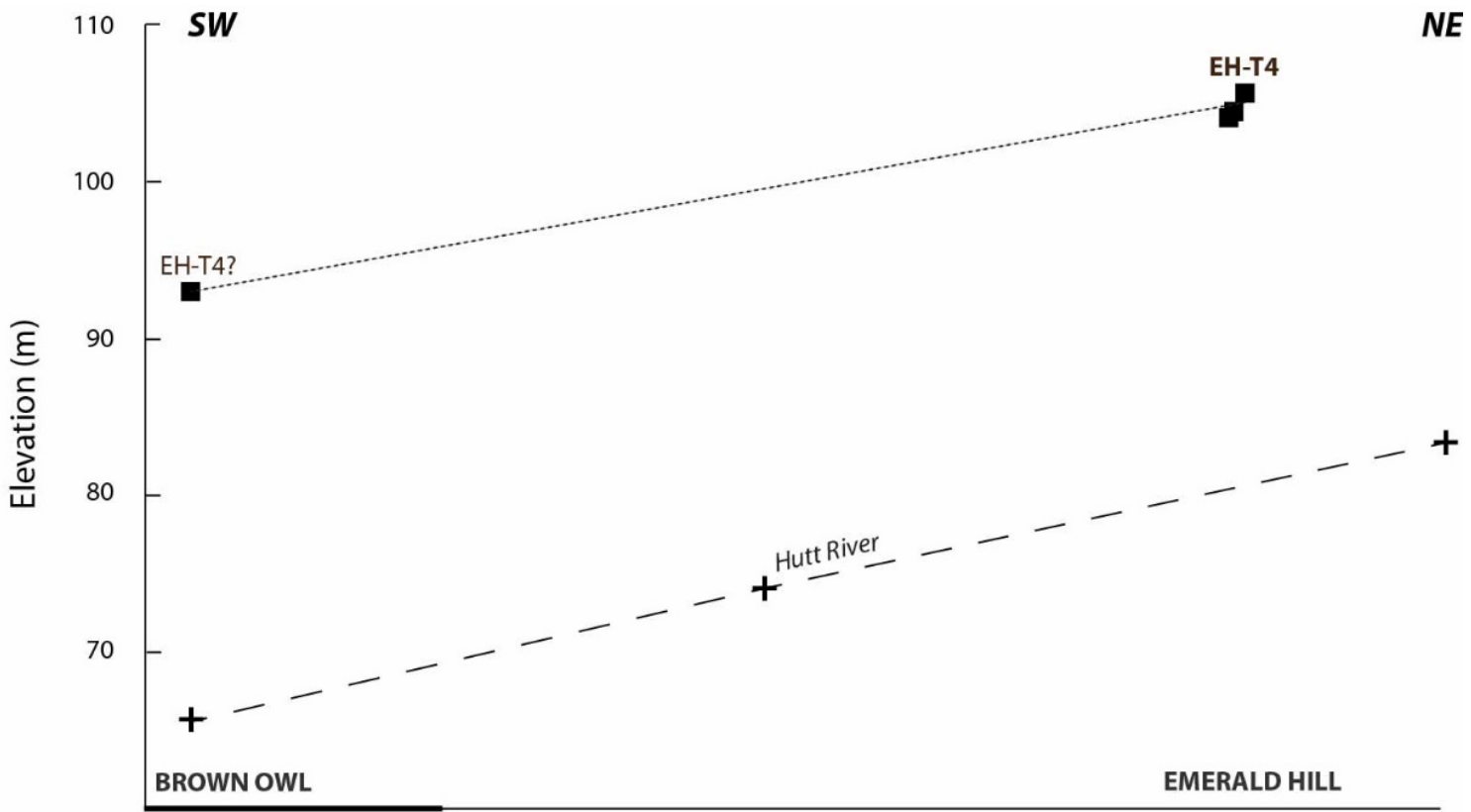

0

$1000(\mathrm{~m})$

b)

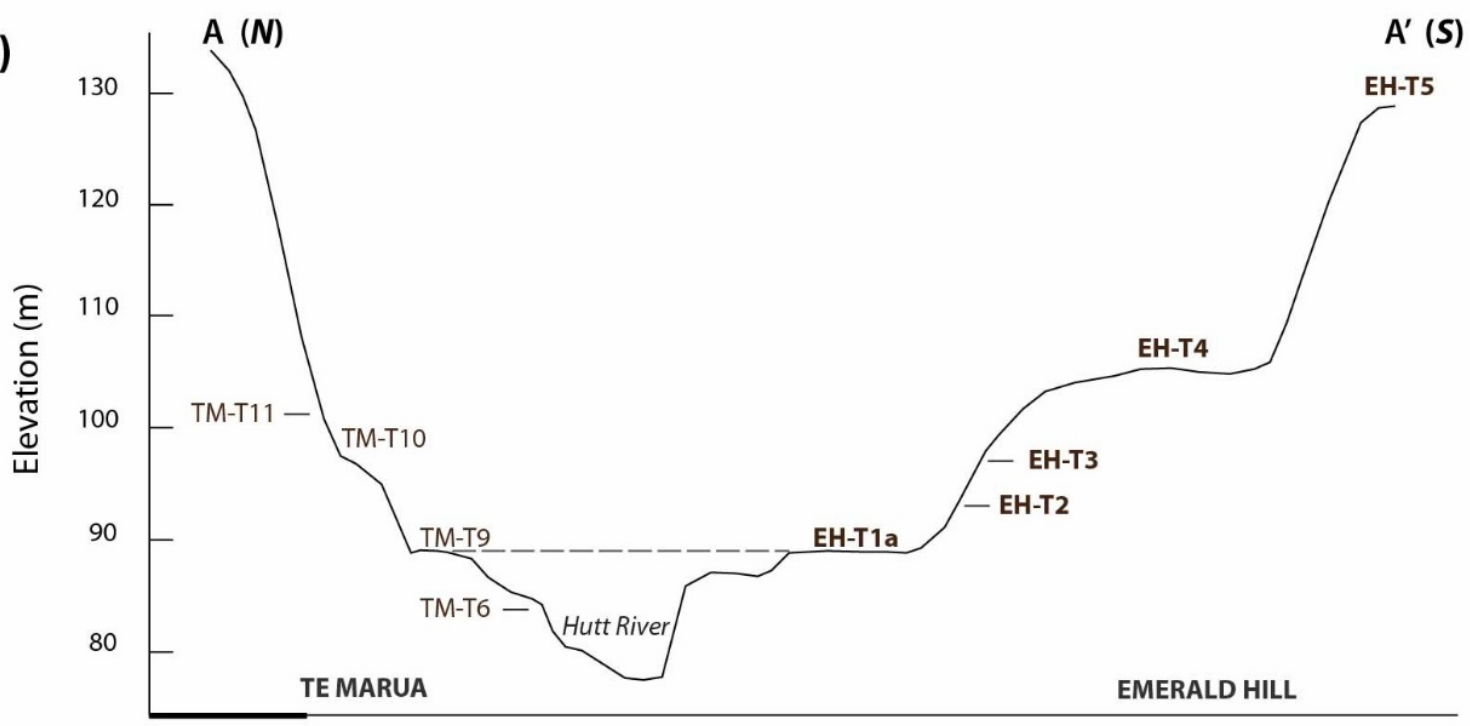

0

$100(\mathrm{~m})$

Figure 2.8. a) Profile used to evaluate whether the terrace remnant at Brown Owl is equivalent to EH-T4 at Emerald Hill, as previously suggested (by Berryman, 1990). This profile was created by interpolating between elevation measurements (relative to mean sea level) of i) the top of the fluvial gravels at each of the sites (solid squares), and ii) sites along the Hutt River (crosses), collected using RTK-GPS. This profile shows the terraces are equally elevated above the current-day river level; b) Example of a river-perpendicular profile, A-A', which identifies Te Marua terrace TM-T9 as being equivalent in elevation above the river to Emerald Hill terrace EH-T1a. Profile location is shown in Fig. 5. Elevation plotted is relative to mean sea level. 


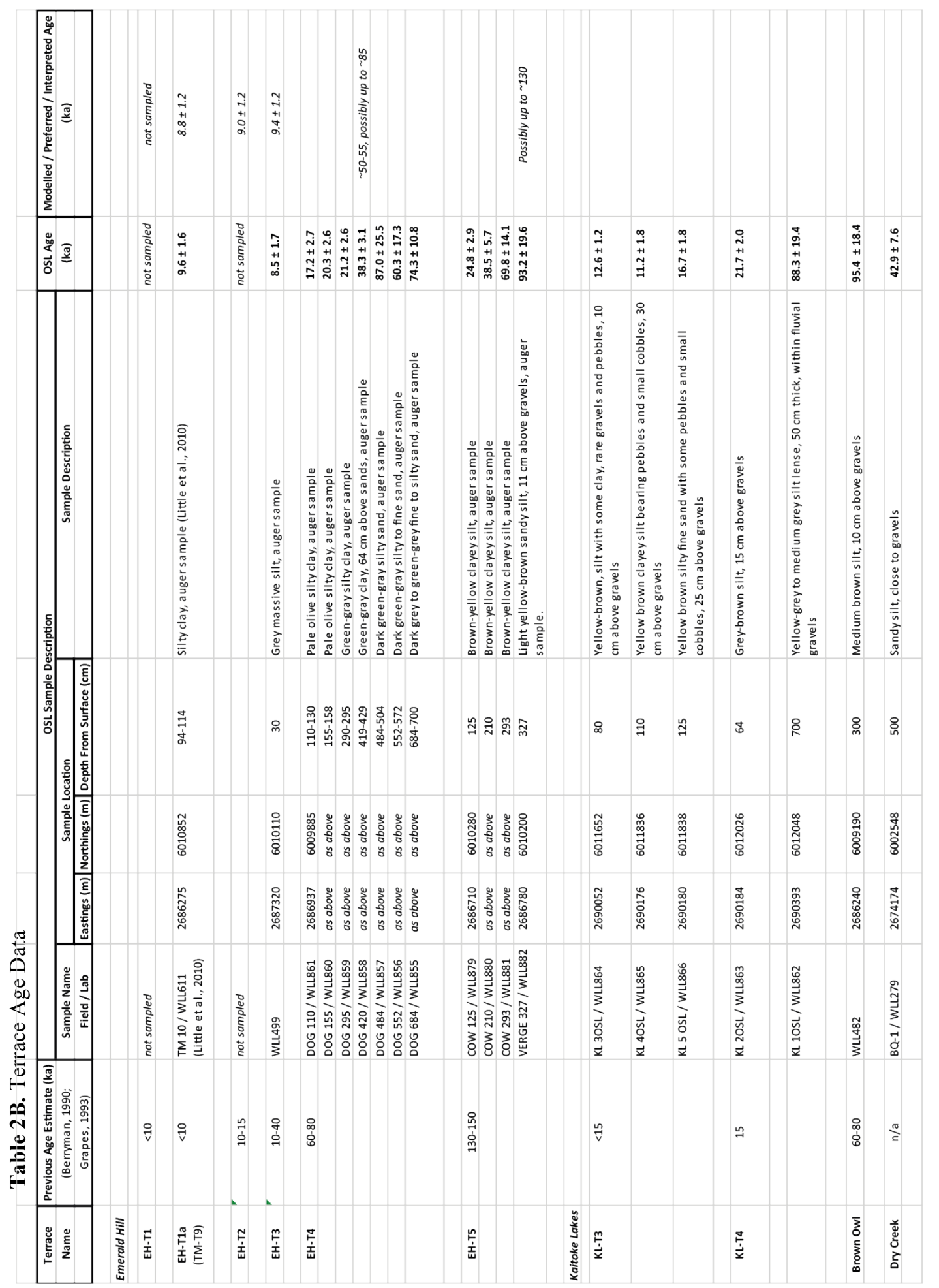

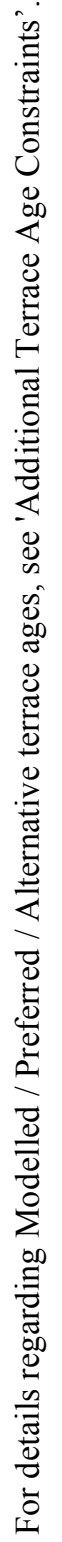




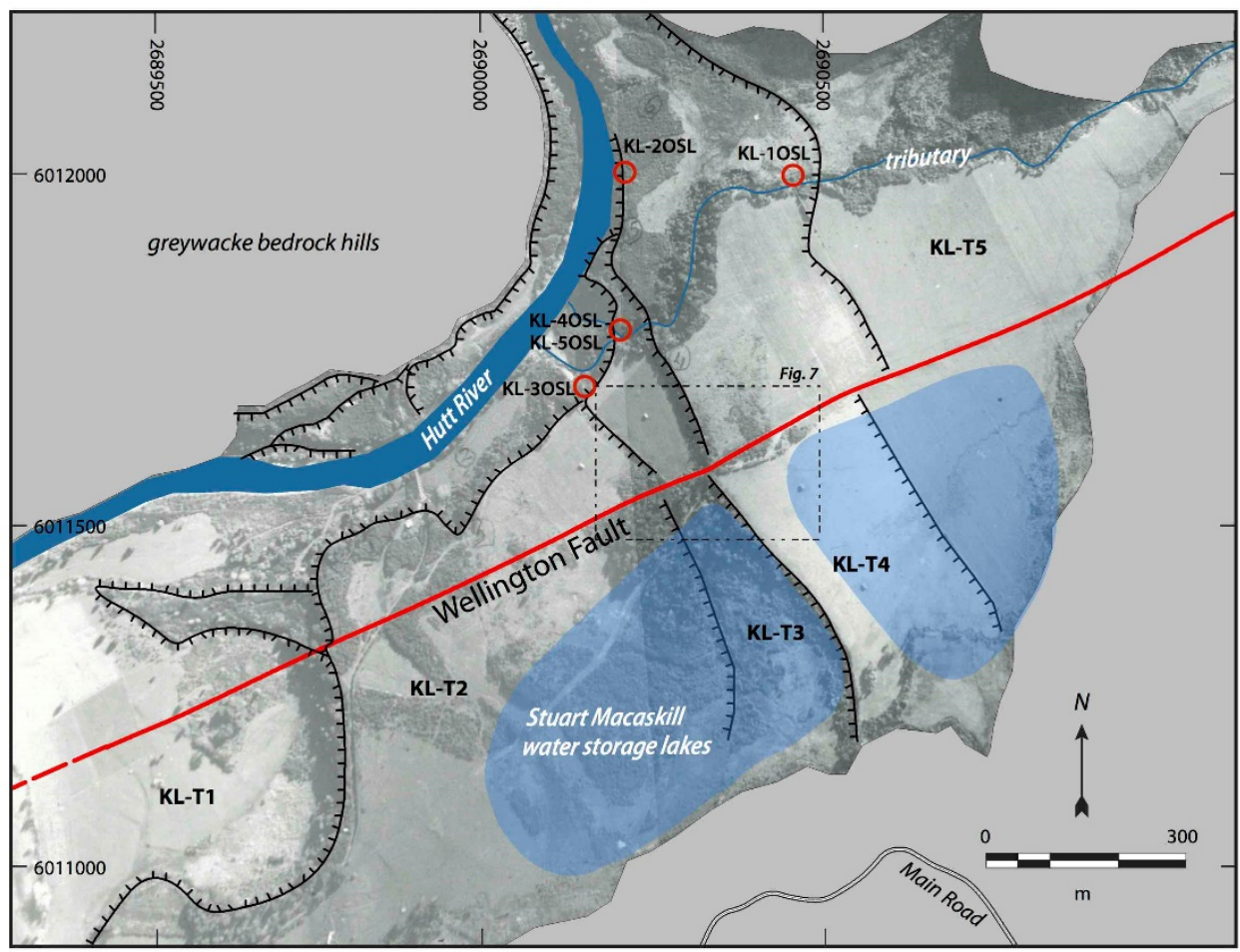

Figure 2.9. Simplified map of terraces at Kaitoke Lakes, superimposed on aerial photos (New Zealand Aerial Mapping, Run 321 Photos 32-33). Figure shows OSL sample collection sites (open circles), location of terrace riser offsets presented in Fig. 7 (dashed square) and Stuart Macaskill water storage lakes. Hutt River flows from north to south. Grid marks are New Zealand Map Grid (Lee, 1978) (Geodetic Datum 1949) eastings and northings (meters).

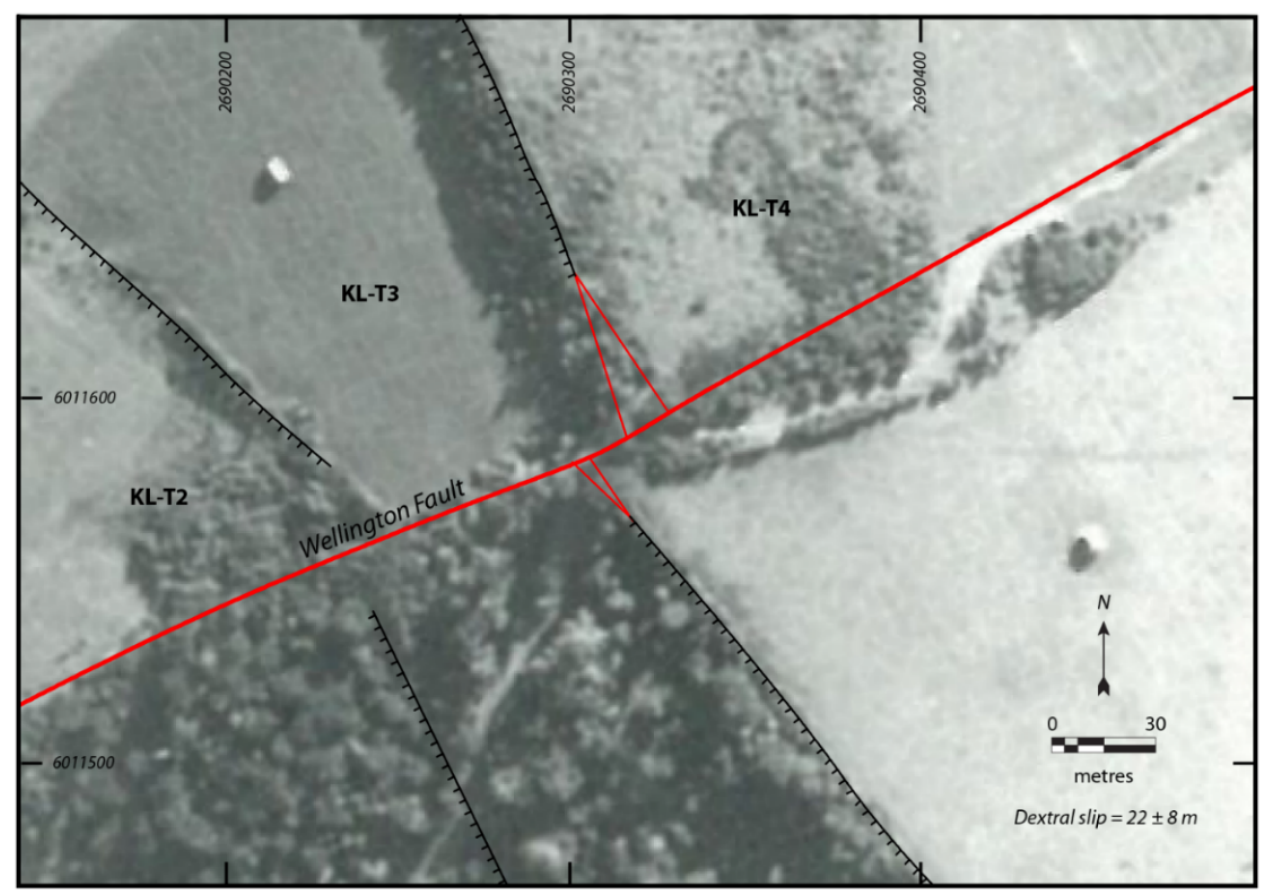

Figure 2.10. Displacement of riser KL-T3-T4 by the Wellington Fault at Kaitoke Lakes. Linear riser projections are shown and provide maximum and minimum displacements. Grid marks are New Zealand Map Grid (Lee, 1978) (Geodetic Datum 1949) eastings and northings (meters). 
area was modified during to the construction of water storage lakes at that site. At a riverbank exposure of KL-T3, two samples (KL-4OSL, KL-5OSL, see Fig. 2.9) were collected from a silt deposit bearing pebbles, $25-30 \mathrm{~cm}$ above fluvial gravels exposed in the banks of a stream, yielding OSL ages of $11.2 \pm 1.8 \mathrm{ka}$ and $16.7 \pm 1.8 \mathrm{ka}$. A third silt sample (KL-OSL3, see Fig. 2.9) collected from $\sim 10 \mathrm{~cm}$ above fluvial gravels at a different location on this terrace yielded an OSL age of $12.6 \pm 1.2 \mathrm{ka}$. We apply the youngest of these ages, $11.2 \pm 1.8 \mathrm{ka}$, as a minimum age for the abandonment of KL-T3.

\subsubsection{Additional Terrace Age Constraints}

To obtain an accurate slip-rate, a precise age for the timing of terrace abandonment is crucial, as this is the time from which we infer that fault-displacement begins to accumulate on a riser. Our newly acquired OSL ages from Emerald Hill and Kaitoke Lakes provide us with much improved estimates of terrace ages compared to estimates available previously. However, the OSL data are not without their complexities of interpretation and some of the abandonment events are only loosely constrained because samples could not be collected close enough to the fluvial gravel-coverbed contact. In this section we apply the knowledge that within a sequence, terraces are progressively younger with decreasing elevation. We focus mainly on the relative ages of the terraces at Emerald Hill, based on their vertical position within the terrace sequence. We also compare our terrace ages to radiometric ages of terraces from other regions in the North Island of New Zealand to provide further stratigraphic and geomorphic context for the faulted terraces, and to help better evaluate their abandonment ages. Because we did not date the terraces both above and below our offset riser at Kaitoke Lakes, we do not here discuss the Kaitoke Lakes terrace data further.

\subsubsection{Terrace Abandonment Ages}

OSL ages obtained from EH-T4 do not provide a narrow estimate of timing of abandonment for this terrace. Sample DOG 420, collected $\sim 60 \mathrm{~cm}$ above the silt/sand contact (which we interpret to be the aeolian/alluvial contact) yielded an OSL age of $38.3 \pm 3.1 \mathrm{ka}$. We consider this to be the age of the older of the two loess units in the EH-T4 coverbed sequence (see Fig. $2.7 \mathrm{c}$ ). The age of deposition of the underlying (interpreted as fluvial) sands yields a pooled mean age of $72.3 \pm 8.8 \mathrm{ka}$, therefore imprecisely bracketing the abandonment of EH-T4 to between $\sim 35$ and $\sim 81 \mathrm{ka}$.

Litchfield and Berryman (2005) mapped and dated fluvial terraces in 8 major catchments across the eastern length of the North Island. Using OSL and radiocarbon data, loess and tephra 
stratigraphy and geomorphology, they identified three aggradational terraces that appear to be a common feature across all of the 8 catchments they investigated. OSL data for one such terrace, their ' $\mathrm{T} 3$ ', yielded ages of $\sim 64-81 \mathrm{ka}$ from within the fluvial deposits, and $39.7 \pm 4.9$ ka from within the immediately overlying loess coverbed. Further, Litchfield and Berryman (2005) report that the 43-50 ka Rotoehu Tephra (more recently constrained by ${ }^{40} \mathrm{Ar} /{ }^{39} \mathrm{Ar}$ dating to $47.4 \pm 1.5 \mathrm{ka}$ (Flude \& Storey, 2016)) directly overlies 'T3' fluvial deposits in the northeastern North Island. On this basis, Litchfield and Berryman (2005) assign a minimum age for 'T3' of 50-55 ka (i.e. the time that aggradation of 'T3' ceased). Given that the ages of deposition of ' $\mathrm{T} 3$ ' are within the bracketed minimum and maximum age range obtained from the EH-T4 fluvial deposits, and the age of the loess immediately overlying 'T3' is within error of that overlying EH-T4, we propose that the timing of abandonment of EH-T4 is $~ 50-55 \mathrm{ka}$.

Our OSL data suggest a rapid rate of abandonment between degradational terraces EH-T1a and EH-T3. Indeed, the mean age of EH-T1a, $9.6 \pm 1.6 \mathrm{ka}$ (based on our geomorphological correlation with terrace TM-T9 of Little et. al., (2010)) is slightly older than that of the higher EH-T3 $-8.5 \pm 1.7 \mathrm{ka}$. The relative elevation of these terraces tells us that EH-T3 must be older than EH-T1a. Moreover, enough time passed between the abandonment of these two terraces for another terrace, EH-T2, to have formed in the interim. We therefore impose these geomorphically-determined relative ages for EH-T1a, EH-T2 and EH-T3 to refine our age estimates of their abandonment.

In the case of EH-T1a and EH-T3, random samples were selected from within Gaussian probability distributions of their original OSL ages, and so long as the sample met the criteria provided by our geomorphological observations, namely, that EH-T1a is younger than EH-T3, then the sample age was kept. This Monte Carlo process of random sample selection described above was repeated for 10,000 compliant samples. Using the retained, compliant samples, our resulting modelled age for EH-T1a was $8.8 \pm 1.3 \mathrm{ka}$, and that of terrace EH-T3 was $9.4 \pm 1.3$ ka. Details of this method and the equivalent calculations by numerical integration of the probability functions are provided in Appendix $C$.

We now consider the amount of incremental displacement, $\sim 32 \mathrm{~m}$ (our preferred dextral displacement estimate, based on the curved riser projection), that occurred between the abandonment of terraces EH-T3 and EH-T2. By comparison, only $\sim 25 \mathrm{~m}$ of slip has accumulated since the abandonment of EH-T2. We expect that enough time passed between the abandonment of EH-T3 and EH-T2 for $\sim 32 \mathrm{~m}$ of displacement to have accumulated. We consider the original OSL age probability distribution for each of EH-T1a and EH-T3, the terraces that bound EH-T2, and from each pair, $t_{1}, t_{3}$, of the retained Gaussian random variables, 
selected random samples from a triangular probability distribution between $t_{1}$ and $t_{3}$ with its apex at $t_{l}$, which maximises the age between EH-T2 and EH-T3. Each triangular sample is thus a valid possible age, $t_{2}$, for EH-T2. A triangular distribution was chosen because it is the simplest form that produces the required effect. From the resulting distribution of valid ages for EH-T2, we obtain a mean modelled age of $9.0 \pm 1.3 \mathrm{ka}$. This value is only $0.1 \mathrm{ka}$ smaller than the mean of a distribution of samples from a uniform distribution between $t_{l}$ and $t_{3}$.

To test the sensitivity of the modelling, we incorporated another OSL age, collected from fine sand $\sim 25 \mathrm{~cm}$ above gravels on the TM-T11 terrace at Te Marua (see Little et al., 2010 for stratigraphic description). This terrace, which is higher in elevation (i.e. older) than EH-T3, but which does not have a geomorphologically correlative terrace at Emerald Hill, yielded an OSL age of $11.1 \pm 2.2 \mathrm{ka}$. Including this maximum age constraint in the modelling of terrace abandonment for EH-T1a, EH-T2 and EH-T3 made a negligible difference to their final calculated ages (Fig. 2.11).

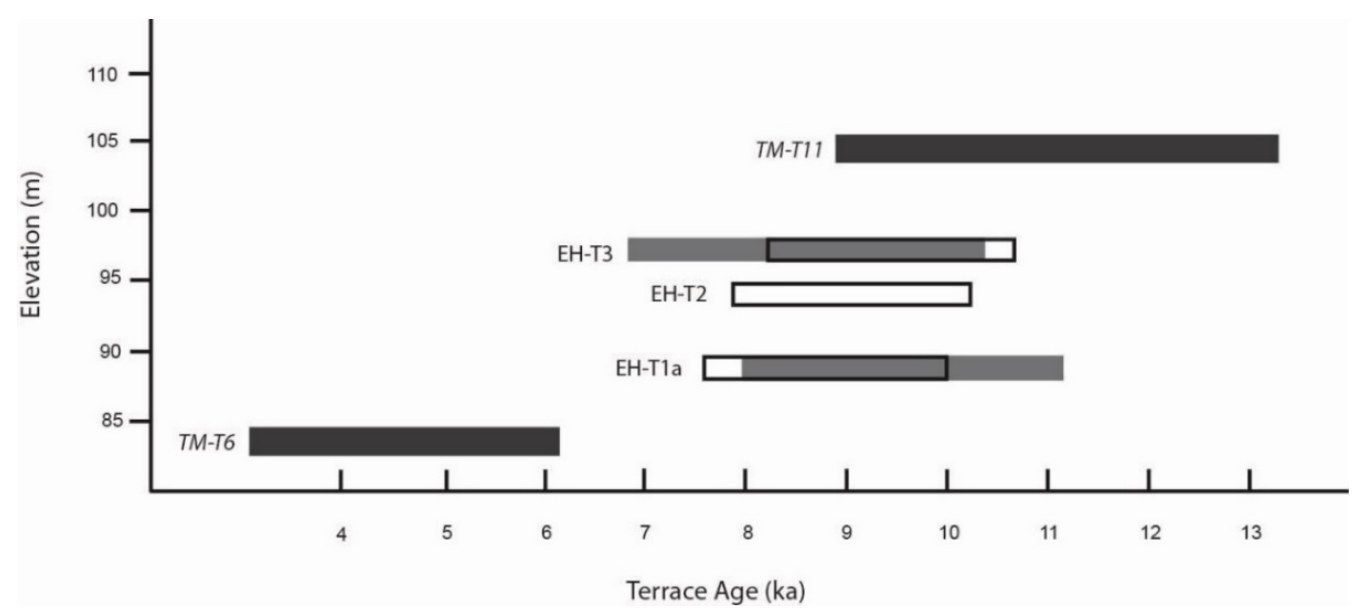

Figure 2.11. Emerald Hill terrace OSL ages $(2 \sigma)$ for EH-T1a and EH-T3 (light grey solid rectangle) and the modelled terrace ages for EH-T1a, EH-T2 and EH-T3 (black outline rectangle). Terraces are plotted against elevation relative to mean sea level (approximate). Also shown for comparison are the elevations and ages of Te Marua terraces TM-T6 and TM-T11 (dark grey solid rectangle) (Little et al., 2010).

\subsubsection{Further Age Considerations - Aggradational vs Degradational Terrace Riser Trimming}

We make the assumption that fault displacement begins to accumulate on a terrace riser only after the river abandons the tread below. This assumption is reasonable for degradational terraces, which form when the river down-cuts into the landscape. Aggradational terraces, however, form when the river valley fills with an influx of deposits, and risers which have formed between aggradational terraces may have a more complicated history of trimming. 
Previous workers have shown that in the North Island of New Zealand, aggradation commonly occurs during cool climate (glacial/stadial) periods when there is an increased sediment flux from catchment headwaters (e.g., Pillans, 1991 and references therein; Litchfield and Berryman, 2005 and references therein). When temperatures rise and aggradation ceases, the river reverts to downcutting into the aggradational gravels. It is at the beginning of this period of downcutting that a riser is first cut into an aggradational terrace. Aggradation in the river catchment repeats when another cool period follows. During this stage, a riser adjacent to a newly-forming, lower aggradational terrace may or may not be further trimmed. Therefore, although the time that aggradation of the lower terrace ceased can still be considered a minimum age for when fault displacement began to accumulate on a riser, it may underestimate that age by tens of thousands of years if the riser was not completely re-trimmed during that period of aggradation. To resolve when displacement on a riser started to accumulate, we also need to consider the earliest possible time that the riser was last trimmed; the beginning of the warmer-climate downcutting following aggradation of the upper terrace provides this maximum age.

At Emerald Hill, both EH-T5-T6 and EH-T4-T5 exist between aggradational terraces. We do not have OSL data to constrain the age of the EH-T6 terrace above riser EH-T5-T6, however we would expect this terrace to have been deposited in the glacial/stadial period preceding the formation of EH-T5, at $93.2 \pm 19.6 \mathrm{ka}$. We employ the currently available age estimates for glacial/stadial periods (Lisiecki and Raymo, 2005), to apply a maximum age of $\sim 130 \mathrm{ka}$ (correlating with the end of marine isotope stage (MIS) 6) for the EH-T5-T6 riser. Our OSL data for the abandonment of EH-T5 provides a maximum age for EH-T4-T5 of $93.2 \pm 19.6 \mathrm{ka}$ (MIS5b or MIS5d). In the interest of representing reasonable extreme age values for the faultdisplaced terrace risers, we consider these scenarios in our slip rate calculations.

\subsubsection{Slip Rate Calculations}

We now apply our new displacement measurements and terrace ages for the fault-offset fluvial terraces at Emerald Hill and Kaitoke Lakes to calculate a slip rate for the southernmost segment of the Wellington Fault (Table 2C, Fig. 2.12). We focus mainly on determining the horizontal slip rate, because the vertical displacement of the Wellington Fault is on average $<10 \%$ of the horizontal rate (Berryman, 1990) and varies along-strike. All slip rate estimates are quoted to $2 \sigma$. 


\subsubsection{Horizontal Slip Rate Calculations}

When considering our riser displacement measurement from EH-T5-T6 and age for the abandonment of terrace EH-T5, we calculate an average maximum slip rate of $6.3 \pm{ }_{1.2}^{1.9} \mathrm{~mm} / \mathrm{yr}$ for the last $\sim 100$ ka years. This is within error of the average slip rate for the Wellington Fault reported by Berryman (1990) over the last $\sim 140 \mathrm{ka}$, despite the different methods used for determining terrace fault-offsets and ages. However, because the terrace below the EH-T5-T6 riser is an aggradational terrace, it is conceivable that the riser is older than the $\sim 93$ ka suggested by the OSL data. For reasons presented earlier, EH-T5-T6 may have last been trimmed up to $\sim 130$ ka ago; the start of the warm-climate period when downcutting commenced on the EHT6 terrace (end MIS 6). In this scenario, the slip rate calculated from EH-T5-T6 could be as low as $\sim 4.5 \mathrm{~mm} / \mathrm{yr}$ (Fig. $2.12 \mathrm{a}$ ).

Table 2C. Summary of Wellington Fault slip rate calculations

\begin{tabular}{|c|c|c|c|c|c|c|}
\hline \multirow[t]{2}{*}{ Landform } & \multicolumn{2}{|c|}{ Fault Displacement (m) } & \multirow[t]{2}{*}{ Age (ka) } & \multicolumn{2}{|c|}{ Slip Rate (mm/yr) } & \multirow[t]{2}{*}{ Comment } \\
\hline & Preferred & Range & & Mean & Range & \\
\hline \multicolumn{7}{|l|}{ Emerald Hill } \\
\hline \multirow[t]{2}{*}{ EH-T5-T6 Riser } & 586 & $571-601$ & $93.2 \pm 19.6$ & 6.3 & $5.1-8.2$ & Age of riser determined from OSL dating \\
\hline & & & $\sim 130$ & 4.5 & $4.4-4.6$ & $\begin{array}{l}\text { Max possible riser age, based on time of upper terrace (EH-T6) } \\
\text { abandonment (end MIS6) (Lisiecki \& Raymo, 2005) }\end{array}$ \\
\hline \multirow[t]{3}{*}{ EH-T4-T5 Ris er } & 463 & $436-526$ & $38.3 \pm 3.1$ & 12.1 & $10.5-14.9$ & OSL age, poorly constrained (min.) \\
\hline & & & $\sim \mathbf{5 0 - 5 5}$ & 8.8 & $7.9-10.5$ & Age of riser based on 'T3' of Litchfield \& Berryman (2005) \\
\hline & & & $93.2 \pm 19.6$ & 5.0 & $3.9-7.1$ & $\begin{array}{l}\text { Max possible riser age, based on time of upper terrace (EH-T5) } \\
\text { abandonment (OSL-determined) }\end{array}$ \\
\hline \multirow[t]{2}{*}{ EH-T3-T4 Riser } & 57 & $34-84$ & $8.5 \pm 1.7$ & 6.7 & $3.3-12.4$ & Age of riser determined from OSL dating \\
\hline & & & $9.4 \pm 1.3$ & 6.1 & $3.2-10.2$ & Riser age based on OSL data with additional geomorphic constraints \\
\hline EH-T2-T3 Riser & 25 & $22-28$ & $9.0 \pm 1.3$ & 2.8 & $2.2-3.6$ & Riser age based on OSL data with additional geomorphic constraints \\
\hline \multicolumn{7}{|l|}{ Kaitoke Lakes } \\
\hline KL-T3 - KL-T4 & 22 & $14-30$ & $11.2 \pm 1.8$ & 2.0 & $1.1-3.1$ & Slip deficit possibly due to off-fault deformation \\
\hline
\end{tabular}

Preferred fault displacement estimates are based on curved projections; displacement Range estimates are based on linear projections $(2 \sigma)$ - see 'Approach - Measuring Fault Displacement' for more details. For details regarding alternative terrace ages see 'Additional Terrace Age Constraints'.

Mean slip rate is calculated from the Preferred fault displacement estimates.

At face value, the cumulative slip rate determined from the fault-offset EH-T4-T5 riser, using the OSL data for EH-T4, is significantly higher; $12.1 \pm{ }_{1.6}^{2.8} \mathrm{~mm} / \mathrm{yr}$. The age applied for this estimate $(38.3 \pm 3.1 \mathrm{ka})$ was obtained from coverbeds deposited some time after the terrace was abandoned (at least enough time for $\sim 60 \mathrm{~cm}$ of sediment to accumulate on the fluvial gravels). This age most likely underestimates the timing of abandonment of EH-T4, and consequently overestimates the slip rate. We instead assign an age to EH-T4 based on the results of Litchfield and Berryman (2005) for their wide-spread ' $\mathrm{T} 3$ ' terrace, $\sim 50-55 \mathrm{ka}$, resulting in a reduced slip 
rate estimate of $8.8 \pm{ }_{0.9}^{1.7} \mathrm{~mm} / \mathrm{yr}$. If we consider the alternative, maximum age of trimming of the EH-T4-T5 riser of $93.2 \pm 19.6 \mathrm{ka}$ (abandonment age of upper terrace, EH-T5) we obtain a minimum slip rate of $5.0 \pm{ }_{1.1}^{2.1} \mathrm{~mm} / \mathrm{yr}$.

The cumulative slip rate calculated for the last 8.2-10.6 ka from terrace EH-T3 at Emerald Hill is $6.1 \pm{ }_{2.9}^{4.1} \mathrm{~mm} / \mathrm{yr}$, calculated using the modelled age for EH-T3. Using the true OSL age (i.e. without imposing any constraints based on its known position relative to other terraces above and below it) gives a higher slip rate of $6.7 \pm{ }_{3.4}^{5.7} \mathrm{~mm} / \mathrm{yr}$. The large errors associated with this slip rate are due to the uncertainties related to the EH-T3 riser displacement, and place this slip rate within error of both the $\sim 50 \mathrm{ka}$ and $\sim 100 \mathrm{ka}$ average. The displacement and modelled age data from EH-T2, which is only slightly younger than EH-T3 (by $\leq 2.8 \mathrm{ka}$ ), yields a slower slip rate of $2.8 \pm 0.6 \mathrm{~mm} / \mathrm{yr}$ since it was abandoned between 7.8-10.2 ka (Fig. $2.12 \mathrm{~b}$ ).

At Kaitoke Lakes, the displacement-age relations from riser KL-T3-T4 suggests a cumulative slip rate of $2.0 \pm{ }_{0.9}^{1.1} \mathrm{~mm} / \mathrm{yr}$ since its abandonment during 9.4-13 ka. This slip rate is slightly less than, but still within error of, that calculated from EH-T2 at Emerald Hill.

Using evidence from Te Marua, from a terrace displaced by $20.8 \pm 0.8 \mathrm{~m}$ and with an age of $\sim 4.5 \mathrm{ka}$, Little et al. (2010) calculated a slip rate for the Wellington Fault of $4.5 \pm 0.4 \mathrm{~mm} / \mathrm{yr}$ since that time.

\subsubsection{Vertical Slip Rate Calculations}

Reports of the ratio of horizontal to vertical motion on the Wellington Fault vary, depending on the age of the offset feature and the site of reference. For instance, at Te Marua the horizontal to vertical ratio has been calculated as 50:1 for the last $4.5 \pm 0.4 \mathrm{ka}$ (Little et al., 2010) whereas at Harcourt Park (see Fig. 2.1 b) it has been 5:1 for the last 15 ka (Berryman, 1990). Because of the alternating sense of dip-slip on the Wellington Fault, and the along-strike variation in amount of vertical slip depending on both timeframe and location, any attempt to determine a vertical slip rate would result in a spatially-specific estimate only.

At Emerald Hill, the sense of vertical offset alternates; our observed offsets suggest that ground rupture events have, on separate occasions, variably upthrown either the north or south side of the fault. Using vertical displacements determined from our topographic data, measured from the terrace treads (i.e. including the thickness of coverbeds), together with our OSL-obtained terrace abandonment ages, we have calculated the vertical slip rates of the southern section of the Wellington Fault for the last $\sim 100 \mathrm{ka}$. 

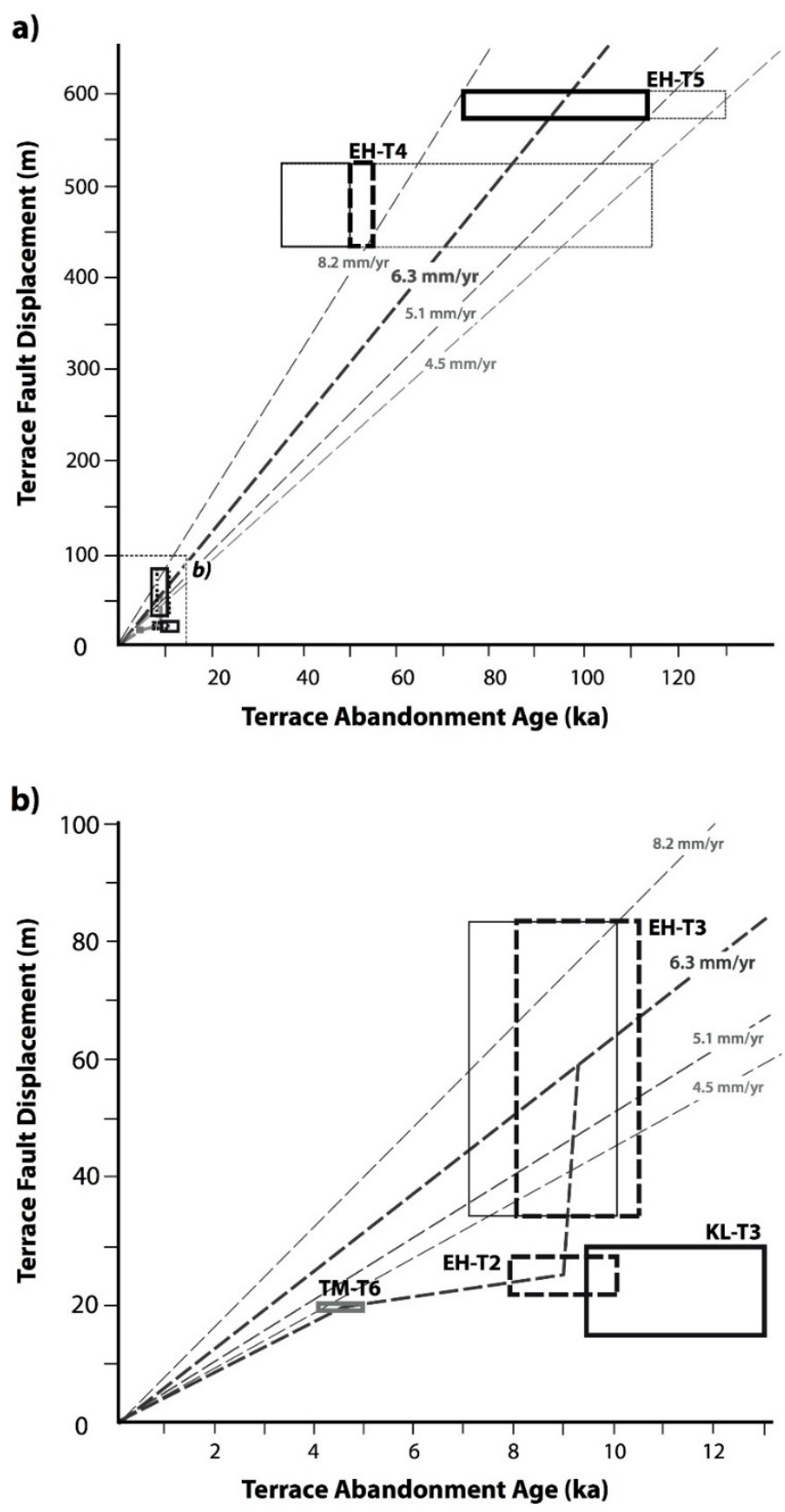

Figure 2.12. a) Terrace displacement/age data and Wellington Fault slip rates from Emerald Hill for the last $\sim 100 \mathrm{ka}$. OSL-derived terrace abandonment ages (shown as solid outline rectangles); alternative age ranges (shown as dashed outline rectangles); preferred ages (shown with a bold outline). Plotted slip rates are calculated from displacement/age data from EH-T5; average slip rate is shown in bold; b) Displacement/age data for the last $\sim 10 \mathrm{ka}$. OSL-derived terrace abandonment ages (shown by solid outline rectangles), modelled/preferred ages (shown as dashed outline rectangles). Data for TM-T6 from Te Marua (Little et al., $2010)$ shown in solid grey outline rectangle. Wellington Fault long-term $(\sim 100 \mathrm{ka})$ slip rates are plotted for comparison. 
The vertical offsets observed for terrace EH-T5, which is upthrown to the north, suggests a long-term vertical slip rate of $0.09-0.14 \mathrm{~mm} / \mathrm{yr}$ (using our OSL age of the terrace) for the last $\sim 100 \mathrm{ka}$. EH-T4, upthrown to the south, has a vertical slip rate of $\sim 0.02 \mathrm{~mm} / \mathrm{yr}$ for the last $\sim 50$ $55 \mathrm{ka}$. For the Holocene, the vertical slip rate of the Wellington Fault, calculated from the EHT3 (upthrown to the south) and EH-T2 (upthrown to the north) terrace treads, is 0.05-0.06 $\mathrm{mm} / \mathrm{yr}$ and $0.02-0.03 \mathrm{~mm} / \mathrm{yr}$, respectively.

We have also calculated a slip rate from Dry Creek, $15 \mathrm{~km}$ south of Emerald Hill. There, a terrace which yielded an age of $42.9 \pm 7.8 \mathrm{ka}$, is offset by at least $56 \mathrm{~m}$ - a minimum measurement because the downthrown equivalent of the dated terrace gravels are inferred to now lie buried at an unknown depth beneath accumulating gravels of the Hutt River. This faultoffset feature suggests a vertical slip rate of $1.3 \pm 0.3 \mathrm{~mm} / \mathrm{yr}$ over the last $\sim 43 \mathrm{ka}$ at this site higher than that calculated from the similarly-aged EH-T4 terrace at Emerald Hill.

\subsection{Discussion}

\subsubsection{A comparison of Wellington Fault Slip Rate between Emerald Hill and Kaitoke Lakes}

At Kaitoke Lakes, we concentrated on the displacement of the riser between terraces KL-T3 and KL-T4 because these terraces are similar in elevation above the river to EH-T2, EH-T3 and EH-T4 at Emerald Hill, allowing for a comparison of slip rate estimates between these two sites. At Kaitoke Lakes, terraces KL-T4 and KL-T3 are 25-30 $\mathrm{m}$ and 15-20 m above the river, respectively, while at Emerald Hill EH-T4, EH-T3 and EH-T2 are $\sim 30 \mathrm{~m}, \sim 20 \mathrm{~m}$ and $\sim 18 \mathrm{~m}$ above the river, respectively. OSL data from both sites places the abandonment of KL-T3 (9.4$13 \mathrm{ka})$ within error of both EH-T2 (7.8-10.2 ka) and EH-T3 (8.2-10.6 ka).

Based on elevation above the river and terrace age, we infer that KL-T3 is equivalent to EHT2 at Emerald Hill. Using the displacement of the KL-T3-T4 riser and the OSL age of abandonment of terrace KL-T3, we have calculated a slip rate of $2.0 \pm{ }_{0.9}^{1.1} \mathrm{~mm} / \mathrm{yr}$ from Kaitoke Lakes. From the EH-T2-EH-T3 riser at Emerald Hill, we have determined a slip rates of $2.8 \pm$ ${ }_{0.6}^{0.8} \mathrm{~mm} / \mathrm{yr}$. Although the slip rates calculated from these similar-aged terraces at different sites are within error, they may also suggest that slip at Kaitoke Lakes is less than at Emerald Hill. This could be explained by some amount of off-fault deformation in the former region, or if rupture at this northern end of the Wellington-Hutt Valley section of the fault is transferred to nearby faults, such as the more northerly Tararua section of the Wellington fault (see Fig. 2.1 b). A slip deficit at Kaitoke Lakes could also be rationalised if there is a lesser amount of nearsurface deformation here, which may occur if this tip of the fault is not well developed (Cowie 
and Scholz, 1992a; 1992b). If, in fact, KL-T3 were equivalent to EH-T3 at Emerald Hill, the difference in slip between these two sites would be even greater $-2.0 \pm{ }_{0.9}^{1.1} \mathrm{~mm} / \mathrm{yr}$ versus $6.1 \pm$ ${ }_{2.9}^{4.1} \mathrm{~mm} / \mathrm{yr}$, respectively, and there would need to be a much greater amount of unrecognised off-fault deformation at Kaitoke Lakes.

\subsubsection{The Wellington Fault - a History of Variable Slip?}

Our data from Emerald Hill, when considered together with the results from Te Marua by Little et al. (2010), provide us with a complex picture of time-varying slip for the Wellington Fault during the last $\sim 100 \mathrm{ka}$ (see Fig. 2.12). Based on our revised displacement measurements and new OSL data, the difference in slip rate calculated from terraces EH-T5 and EH-T4 suggests that fewer ground rupture events took place between $\sim 100-50 \mathrm{ka}$ than between $\sim 50 \mathrm{ka}$ and today. However, because the EH-T6, EH-T5 and EH-T4 terraces are aggradational, the precise time of most recent trimming of their risers (the time from which we assume fault displacement begins to accumulate on that feature) is debatable; it is conceivable that the age of these risers may not be well estimated by the OSL-determined age of abandonment of their lower terrace. In addition, the process responsible for the formation of one riser may not have been the same process responsible for a riser formed at a different time. For instance, the EH-T5-T6 riser may have been trimmed at the time of abandonment of the EH-T5 tread below (when deposition of EH-T5 ceased) at $\sim 93 \mathrm{ka}$, as suggested by the OSL data. If however the EH-T4-T5 riser was last trimmed during the period of downcutting immediately following the deposition of upper terrace EH-T5 (i.e. also at $~ 93 \mathrm{ka}$ ) and not when the deposition of the lower terrace EH-T4 ceased (at $\sim 50 \mathrm{ka}$ ) then the slip rates calculated from each of these terrace risers would be within error of one another (see Fig. 2.12 a). Overall, the uncertainties associated with the process and age of formation of these risers, coupled with their limited number (only two over a $\sim 90$ ka period) does not allow for a better resolution of faster versus slower fault slip for the period $\sim 100-10 \mathrm{ka}$.

The evidence of clustered ground rupture activity within the last $\sim 10 \mathrm{ka}$ is more compelling (see Fig. 2.12 b) notably due to the greater number of distinct offset risers preserved from this time period. Our data indicate a marked increase in terrace displacement between $\sim 10 \mathrm{ka}$ and $\sim 8 \mathrm{ka}$, the time of abandonment of terraces EH-T3 and EH-T2, respectively. We estimate that an incremental displacement of $\sim 32 \mathrm{~m}$ took place during this period. By contrast, since the abandonment of EH-T2 at $\sim 8 \mathrm{ka}$, only $\sim 25 \mathrm{~m}$ of displacement has accumulated on the fault. The single-event displacement observed by Little et al. (2010) of $\sim 5 \mathrm{~m}$ for the last 4 events, suggests that the $\sim 25 \mathrm{~m}$ of displacement since $\sim 8 \mathrm{ka}$ represents $\sim 5$ ground rupture events. 
Further, Little et al. (2010) showed that the last $20 \mathrm{~m}$ of slip on this part of the fault resulted from the last 4 events, which took place in the last $4.5 \pm 0.4 \mathrm{ka}$. It follows then that after the period of heightened activity between $\sim 10-8 \mathrm{ka}, \leq 1$ event took place on the Wellington Fault between $~ 8-4.5 \mathrm{ka}$, indicating a period of relative quiescence during this time. This was followed by a resurgence of activity, with 4 earthquake ruptures events since $\sim 4.5 \mathrm{ka}$.

\subsubsection{Comparison of Apparent Wellington Fault Temporal Ground Rupture Clustering with}

\section{Paleoseismological Evidence}

Evidence from recent excavations at Te Kopahou, Te Marua and Kaitoke Basin (Langridge et al., 2009), as well as earlier studies at Long Gully and Kaitoke Basin (Van Dissen et al., 1992), indicate that the four most recent ground rupture events occurred on the Wellington Fault since $\sim 4.2 \mathrm{ka}$. These results agree with the progressive terrace displacements from Te Marua (Little et al., 2010) where 4 earthquake slip events were documented since $4.5 \pm 0.4$ ka. At Kaitoke Basin, Langridge et al. (2009) report no evidence of ground rupture activity in the period $~ 7.3$ $4.2 \mathrm{ka}$. They interpret this as possibly due to lack of sedimentation during that time. We note, however, that this period coincides with the episode that we have documented here of relatively little displacement during the period $\sim 8.0-4.5 \mathrm{ka}$. At Kaitoke Basin, evidence was also found for at least five older ground rupture events, between $\sim 11.6-7.3 \mathrm{ka}$ (Langridge et al., 2009). This is consistent with our period of heightened surface rupture activity between $\sim 10-8 \mathrm{ka}$ at Emerald Hill.

In short, two independent data sets, our geomorphic study using OSL and paleoseismology data using radiocarbon dating, yield similar estimates regarding the timing of periods of relative activity and inactivity on the Wellington Fault during the Holocene.

\subsubsection{Temporal Variability in Fault Slip - Conduct and Possible Causes}

During the Holocene, activity on the Wellington Fault appears to be clustered into $\geq 4-5$ events over periods of $\geq 4-5$ ka years, separated by a seismic lull lasting $\sim 4 \mathrm{ka}$. The first period of heightened activity during the Holocene started at least (but possibly earlier than) $\sim 12$ ka ago, based on the earliest available paleoseismological record of ground rupture on the Wellington Fault (Langridge et al., 2009). Paleoseismological data from Kaitoke Basin (Langridge et al., 2009 ) suggests a return period for ground rupture events of $\sim 1075$ years between $\sim 12-8 \mathrm{ka}$. A period of quiescence followed, with data from Emerald Hill showing evidence for fault slip of only $\sim 5 \mathrm{~m}$ between $\sim 8-4.5 \mathrm{ka}$. The timing of this putative earthquake is not well constrained; it may be the last event of the inferred early Holocene period of heightened activity, or the first 
of the most recent cluster of ground rupture events which began $\sim 4.5 \mathrm{ka}$ ago. Paleoseismic results from Langridge et al. (2009) and geomorphic results from Little et al. (2010) suggest that the return period for events during the most recent period of heightened activity, $4.5 \mathrm{ka}$ to the present, is $\sim 610-1575 \mathrm{ka}$. The inferred length of the two periods of heightened activity, $\geq 4-5$ ka years, and the timing of commencement of the most recent cluster raises a question: Might we now be nearing the end of the Late Holocene period of heightened activity on the Wellington Fault, or indeed have commenced a period of relative quiescence?

The clustering of ground rupture activity on faults has been reported worldwide, with the duration of cluster periods and seismic lulls varying from 100's to 10,000's of years. For instance, periods of heightened ground rupture activity on the North Anatolian fault in Turkey have lasted a few hundred years and are separated by similar lengths of quiescence (e.g. Ambraseys, 1970; Ambraseys and Jackson, 1998; Hartleb et al., 2003, 2006). In comparison, cycles of clustering and quiescence on the Dead Sea Transform in Israel have persisted for $\sim 10$ ka (Marco et al., 1996). The temporal clustering of ground rupture activity has also been shown to switch between coupled faults. In a study of the southernmost San Andreas Fault and nearby San Jacinto Fault (Bennett et al., 2004), geologically-determined slip rates averaged over the last 1.5 Ma suggested co-dependence between these structures; the slip rate on the San Andreas decelerates when the San Jacinto accelerates, and vice versa. A similar pattern has also been observed across fault systems. Investigations of faults of the Eastern California shear zone in the western United States of America have revealed system-wide accelerated seismic moment release lasting $\sim 1-1.5 \mathrm{ka}$ (Rockwell et al., 2000; Ganev et al., 2010), which is temporally anticorrelated to similar activity on the San Andreas and other faults in the Los Angeles region (Dolan et al., 2007). It has been suggested that clustering on these fault systems could be the result of fluctuations in the loading rate at depth, such that the regions experience alternate cycles of strain hardening and annealing (Dolan et al., 2007).

In an attempt to explain the clustering of seismic activity on faults, Heaton (1990) used earthquake ground motion data to model fault rupture. He suggested that a cluster of earthquakes could be due to a self-healing slip pulse which propagates so quickly that not enough of the accumulated strain is released in a single event, resulting in a series of ruptures. Using two different approaches, one employing a regional lithospheric model and another of a single strike-slip fault in a 3D half-space, Ben-Zion et al. (1999) showed that under steady tectonic loading, faults could switch between modes of clustered activity of large earthquakes, and periods of low moment release during which only small and intermediate events take place. Using a model which incorporated damage rheology (i.e. rock deformation) Lyakhovsky et al. 
(2001) described a comparable observation of mode switching across a fault network, which alternated between phases of clustered activity (earthquakes of magnitude $>M 6.8$, including ground rupturing events) and periods of relative quiescence (magnitude $<$ M6.8 and fewer ground rupturing events).

Robinson et al. (2011) examined the interaction between the Wellington Fault and the Wairarapa (southern North Island) and Awatere (northern South Island) faults (see Fig. 2.1 a). Their study, which utilises a synthetic seismicity catalogue, shows that rupture of the Wairarapa and Awatere faults delays subsequent rupture on the Wellington Fault by $\sim 260$ years on average, with a lag of up to 2000 years or more also being possible. These results suggest that interactions with nearby faults may, at the very least, be a partial contributor to our documented temporal change in slip rates on the Wellington Fault. However, the precise role of the remaining faults of the NIDFB remains ambiguous; the currently available record of earthquakes across the NIDFB does not exhibit a clear pattern. This record is incomplete and some event times remain poorly constrained. Additional work is required to create a more comprehensive set of paleoseismic records that extend back enough in time to capture several cycles of earthquake activity. Companion theoretical studies of fault mechanisms are also needed if we are to understand the geodynamic processes responsible for the temporal variations in slip on the Wellington Fault, and to evaluate the partitioning of deformation between the upper-plate faults of the Hikurangi forearc and the subduction interface.

\subsection{Conclusion}

We have re-evaluated displacement measurements of fluvial terraces offset by the Wellington Fault at three sites along the Hutt River. Using new OSL data and other geological evidence, we have constrained the ages for these terraces. Combining displacement measurements with terrace ages, we estimate a slip rate for the southernmost segment of the Wellington Fault of $6.3 \pm{ }_{1.2}^{1.9} \mathrm{~mm} / \mathrm{yr}$ for the last $\sim 100 \mathrm{ka}$. However, slip on this fault has not been steady during this time. During the Holocene in particular, the Wellington Fault experienced a period of heightened surface rupture activity between $\sim 10-8 \mathrm{ka}$; a period of relative quiescence between $\sim 8-4.5 \mathrm{ka}$, and renewed activity in the last $\sim 4.5 \mathrm{ka}$. These results corroborate with paleoseismological evidence of the timing of ground rupture events at other sites along the fault. The time-varying activity observed on the Wellington Fault may be regulated by activity on nearby faults. Further work is required to confirm this, to determine any other causes of the observed clustering and, ultimately, to better define earthquake hazard in the Wellington region. 


\section{References}

Aitken, M. J. and J. Xie (1992). Optical dating using infrared diodes: Young samples, Quaternary Sci. Rev. 11 147-152.

Ambraseys, N. N. (1970). Some characteristic features of the North Anatolian fault, Tectonophysics. 9 143-165.

Ambraseys, N. N. and J. A. Jackson (1998). Faulting associated with historical and recent earthquakes in the eastern Mediterranean region, Geophys. J. Int. 133 390-406.

Beanland, S. (1995). The North Island dextral fault belt, Hikurangi subduction margin, New Zealand, Ph.D. thesis. Victoria University of Wellington, Wellington, New Zealand.

Begg, J. G. and C. Mazengarb (1996). Geology of the Wellington area, Geology Map 128, Institute of Geological and Nuclear Sciences Ltd., Lower Hutt, New Zealand.

Benedetti, L., R. Finkel, D. Papanastassiou, G. King, R. Armijo, F. Ryerson, D. Farber, and F. Flerit (2002). Post-glacial slip history of the Sparta fault (Greece) determined by $36 \mathrm{Cl}$ cosmogenic dating: evidence for non-periodic earthquakes, Geophys. Res. Lett. 29, no. 8, 1246, doi:10.1029/2001GL014510.

Bennett, R. A., A. M. Friedrich and K. P. Furlong (2004). Co-dependent histories of the San Andreas and San Jacinto fault zones from inversion of fault displacement rates, Geology, 32, no. 11, 961-964, doi: 10.1130/G20806.1.

Ben-Zion, Y., K. Dahmen, V. Lyakhovsky, D. Ertas and A. Agnon (1999). Self-driven mode switching of earthquake activity on a fault system, Earth Planet. Sci. Lett. 172 11-21.

Berryman, K. R. (1990). Late Quaternary movement on the Wellington Fault in the Upper Hutt area, New Zealand, New Zeal. J. Geol. Geophys. 33 257-270.

Cowgill, E. (2007). Impact of riser reconstructions on estimation of secular variation in rates of strikeslip faulting: Revisiting the Cherchen River site along the Altyn Tagh Fault, NW China, Earth Planet. Sci. Lett. 254 239-255.

Dawson, T. E., S. F. McGill and T. K. Rockwell (2003). Irregular recurrence of paleoearthquakes along the central Garlock fault near El Paso Peaks, California, J. Geophys. Res. 108, B7, 2356, doi:1029/2001JB001744, 2003.

Dolan, J. F., D. D. Bowman and C. G. Sammis (2007). Long-range and long-term fault interactions in Southern California. Geology. 35, no. 9, 855-858, doi:10.1130/G23789A.1.

Eden, D.N. and A.P. Hammond (2003). Dust accumulation in the New Zealand region since the last glacial maximum, Quaternary Sci. Rev. 22 2037-2052.

Flude, S. and Storey, M., 2016. 40Ar/39Ar age of the Rotoiti Breccia and Rotoehu Ash, Okataina Volcanic Complex, New Zealand, and identification of heterogeneously distributed excess $40 \mathrm{Ar}$ in supercooled crystals. Quaternary Geochronology, 33, pp.13-23.

Friedrich, A. M., B. P. Wernicke, A. Niemi, R. A. Bennett and J. L. Davis (2003). Comparison of geodetic and geologic data from the Wasatch region, Utah, and implications for the spectral character of Earth deformation at periods of 10 to 10 million years, J. Geophys. Res. 108, 2199 23, doi:10.1029/2001JB000682. 
Ganev, P. N., J. F. Dolan, K. Blisnuik, M. Oskin and L. A. Owen (2010). Paleoseismologic evidence for multiple Holocene earthquakes on the Calico fault: Implications for earthquake clustering in the eastern California shear zone, Lithosphere. 2, no. 4, 287-298.

Grant, L. B. and K. Sieh (1994). Paleoseismic evidence of clustered earthquakes on the San Andreas fault in the Carrizo Plain, California, J. Geophys. Res. 99, no. B4, 6819-6841.

Grapes, R. (1993). Terrace correlation, dextral displacements, and slip rate along the Wellington Fault, North Island, New Zealand (Letters to the Editor), New Zeal. J. Geol. Geophys. 36 131-135.

Gross R., A. G. Green, H. Horstmeyer and J.H. Begg (2004). Location and geometry of the Wellington Fault (New Zealand) defined by detailed three-dimensional georadar data, J. Geophys. Res. 109, B05401, doi:10.1029/2003JB002615.

Hartleb, R. D., J. F. Dolan, H. Serdar Akyuz and B. Yerli (2003). A 2500-year-long paleoseismologic record of earthquakes along the central North Anatolian fault from trenches at Alayurt, Turkey. Bull. Seism. Soc. Am. 93, no. 5, 1935-1954.

Hartleb, R. D., J. F. Dolan, O. Kozaci, H. Serdar Akyuz and G. G. Seitz (2006). A 2500-yr-long paleoseismologic record of large, infrequent earthquakes on the North Anatolian fault at Cukurcimen, Turkey, Geol. Soc. Am. Bull. 118, no. 7-8, 823-840.

Heaton, T. H. (1990). Evidence for and implications of self-healing pulses of slip in earthquake ruptures, Phys. Earth Planet. In. 64 1-20.

Kneupfer, P. L. K. (1992). Temporal variations in latest Quaternary slip across the Australian-Pacific Plate Boundary, north eastern South Island, New Zealand, Tectonics. 11, no. 3, 449-464, doi:10.1029/91TC02890.

Lang, A. and Wagner, G. A. (1997). Infrared stimulated luminescence dating of Holocene colluvial sediments using the 419nm emission, Quaternary Sci. Rev. 16 393-396.

Langridge, R. M., K. R. Berryman and R. J. Van Dissen (2005). Defining the geometric segmentation and Holocene slip rate of the Wellington Fault, New Zealand: the Pahiatua section, New Zeal. J. Geol. Geophys. 48 591-607.

Langridge, R., P. Villamor, R. Van Dissen and T. Little (2009). It's Our Fault - Wellington Fault paleo-earthquake investigation: Final report, GNS Science Consultancy Report 2008/344, June 2009.

Langridge, R., R. Van Dissen, D. Rhodes, P. Villamor, T. Little, N. Litchfield, K. Clark and D. Clark (2011). Five thousand years of surface ruptures on the Wellington Fault, New Zealand: Implications for recurrence and fault segmentation, Bull. Seism. Soc. Am. 101, no. 5, 20882107.

Lee, L.P., (1978). First-order, geodetic triangulation of New Zealand, 1909-49; 1973-74. Technical Series No. 1, Wellington, Dept. of Lands and Survey.

Lensen, G. J. (1973). Guidebook for Excursion A10: Central New Zealand, IX INQUA Congress 1973, Christchurch, New Zealand, 2-24.

Lisiecki, L. E., and M. E. Raymo (2005). A Plio-Pleistocene stack of 57 globally distributed benthic $\delta 18$ O records, Paleoceanography, 20 1003, doi:10.1029/2004PA001071.

Litchfield, N. J. and K. R. Berryman (2005). Correlation of fluvial terraces within the Hikurangi Margin, New Zealand: implications for climate and baselevel controls, Geomorphology, 68, no. 3-4, 291-313. 
Little, T. A., R. H. Grapes, and G. W. Berger (1998). Late Quaternary strike-slip on the eastern part of the Awatere Fault, South Island, New Zealand, Geol. Soc. Am. Bull. 110 2-23.

Little, T. A., R. Van Dissen, U. Rieser, E. G. C. Smith, and R. Langridge (2010). Coseismic strike-slip at a point during the last four earthquakes on the Wellington Fault near Wellington, New Zealand, J. Geophys. Res. 115, B05403, doi:10.1029/2009JB006589, 2010.

Lyakhovsky, V., Y. Ben-Zion and A. Agnon (2001). Earthquake cycle, fault zones, and seismicity patters in a rheologically layered lithosphere, J. Geophys. Res. 106, B3, 4103-4120.

Marco, S., M. Stein, A. Agnon and H. Ron (1996). Long-term earthquake clustering: A 50,000-year paleoseismic record in the Dead Sea Graben, J. Geophys. Res. $1064103-4120$.

Mason, D. P. M., T. A. Little and R. J. Van Dissen (2006). Rates of active faulting during late Quaternary fluvial terrace formation at Saxton River, Awatere Fault, New Zealand, Geol. Soc. Am. Bull. 118 1431-1446.

Milne, J. D. G. (1973). River terraces in the Rangitikei basin, New Zealand Soil Bureau maps 142/1, 142/2, 142/3, 142/4, Wellington, New Zealand, Department of Scientific and Industrial Research.

Murray, A. S. and A. G. Wintle (2000). Luminescence dating of quartz using an improved singlealiquot regenerative-dose protocol. Radiat. Meas. 32, no. 1, 57-73.

Pillans, B. (1991). New Zealand Quaternary Stratigraphy: An Overview, Quaternary Sci. Rev. 10 405418.

Pondard, N. and P. R. Barnes (2010). Structure and paleoearthquake records of active submarine faults, Cook Strait, New Zealand: Implications for fault interactions, stress loading, and seismic hazard, J. Geophys. Res. 115, B12320, doi:10.1029/2010JB007781.

Robinson, R., R. Van Dissen and N. Litchfield (2011). Using synthetic seismicity to evaluate seismic hazard in the Wellington region, New Zealand, Geophys. J. Int. 187 510-528.

Rockwell, T. K., S. Lindvall, M. Herzberg, D. Murback, T. Dawson, and G. Berger (2000). Paleoseismology of the Johnson Valley, Kickapoo, and Homestead Valley faults: Clustering of earthquakes in the Eastern California Shear Zone, Bull. Seism. Soc. Am. 90 1200-1236.

Stirling, M., McVerry, G., Gerstenberger, M., Litchfield, N., Van Dissen, R., Berryman, K., Barnes, P., Wallace, L. M., Bradley, B., Villamor, P., Langridge, R. M., Lamarche, G., Noder, S., Reyners, M., Rhoades, D., Smith, W., Nicol, A., Pettinga, J., Clark, K., Jacobs, K. (2012). National seismic hazard model for New Zealand: 2010 update, Bull. Seism. Soc. Am. 102 $1514-1542$.

Vandergoes, M.J., Hogg, A.G., Lowe, D.J., Newnham, R.M., Denton, G.H., Southon, J., Barrell, D.J., Wilson, C.J., McGlone, M.S., Allan, A.S. and Almond, P.C., 2013. A revised age for the Kawakawa/Oruanui tephra, a key marker for the Last Glacial Maximum in New Zealand. Quaternary Science Reviews, 74, pp.195-201.

Van Dissen, R., K. R. Berryman, J. R. Pettinga and N. L. Hill (1992). Paleoseismicity of the Wellington-Hutt Valley segment of the Wellington Fault, North Island, New Zealand, New Zeal. J. Geol. Geophys. 35 165-176.

Wallace, L. M., J. Beavan, R. McCaffrey and D. Darby (2004). Subduction zone coupling and tectonic block rotations in the North Island, New Zealand, J. Geophys. Res. 109, B12406, doi: 10.1029/2004JB003241. 
Wallace, L. M., Barnes, P., Beavan, J., Van Dissen, R. J., Litchfield, N. J., Mountjoy, J., Langridge, R. M., Lamarche, G., and Pondard, H. (2012). The kinematics of a transition from subduction to strike-slip: an example from the central New Zealand plate boundary, J. Geophys. Res. Solid Earth, doi: 10.1029/2011JB008640 


\title{
CHAPTER THREE
}

\author{
Distribution, Age and Uplift Patterns \\ of Pleistocene MARine Terraces Along THE \\ SOUTH COAST OF THE NORTH ISLAND, NEW ZEALAND
}

\begin{abstract}
I re-evaluate the distribution and age of Pleistocene marine terraces along the south coast of the North Island of New Zealand. Using modern elevation surveying techniques and new Optically Stimulated Luminescence (OSL) data - the first radiometrically-determined ages for the majority of these terraces - I correlate these features based on their age of formation. Seven marine terraces were identified and mapped along the south coast, occurring discontinuously between Tongue Point and Cape Palliser. The OSL data (21 new ages), when compared to the timing of Marine Isotope Stage (MIS) highstands, indicate that the most commonly preserved terraces formed at MIS 5a, 5c, 5e and 7a respectively. The terraces are best preserved within the forearc region of the Hikurangi margin, generally decrease in altitude towards the west, and are locally offset by active faults, most notably the Wairarapa and Ohariu faults.
\end{abstract}

\subsection{Introduction}

The preservation of marine terraces in coastal regions provides valuable information for investigating tectonic deformation, in particular uplift, at active plate margins worldwide (e.g. Bradley \& Griggs, 1976; Ghani, 1978; Muhs et al., 1990; 1992; Machare \& Ortlieb, 1992; Berryman, 1993; Ortlieb et al., 1996; Ota et al., 1996). Shore platform elevation data (or specifically, that of the shoreline angle) coupled with the age of that terrace allows for an estimate of tectonic uplift to be made. Moreover, the recent advances in dating techniques now provide more precise age control of terraces and, coupled with improvements in elevation surveying methods, allow for more robust uplift estimates (e.g. Zazo et al., 2003; Pedoja et al., 2006; Wilson et al., 2007; Matsu'ura et al., 2009; Saillard et al., 2009, 2011). 
Previous studies of coastal uplift, and its relationship to local subduction processes, have been undertaken across the northern and central east coast, North Island (e.g. Berryman et al., 1989; Ota et al., 1991; Nicol \& Beavan, 2003; Litchfield \& Berryman, 2006; Wilson et al., 2007; Litchfield et al., 2007; Nicol et al., 2007; Berryman et al., 2011), however a margin-wide investigation of deformation has not yet been made across the southernmost North Island, where the degree of interplate locking on the Hikurangi subduction interface is inferred to be highest (e.g. Reyners, 1998, Darby \& Beavan, 2001; Wallace et al., 2004, 2009).

Across the southern North Island, spanning $\sim 100 \mathrm{~km}$ of coastline, a series of marine terraces are elevated to heights of up to $\sim 400 \mathrm{~m}$ above current day sea level, and are preserved as far as $\sim 4 \mathrm{~km}$ inland from the current-day coast (e.g. Begg \& Johnston, 2000). Previous investigations of these features (Ghani, 1974, 1978; Ota et al., 1981; Begg \& Mazengarb, 1996), measured elevations using imprecise and now-outdated surveying techniques, and used the sedimentmantled terrace treads as the paleo-sea level datum, unnecessarily and incorrectly including the thickness of cover beds (which varies between sites, and in places can be as much as $30 \mathrm{~m}$ ) in their elevation estimates. In addition, these previous marine terrace studies failed to date the shore platforms in any comprehensive and consistent way; typically, terrace ages were only roughly estimated, based on a combination of geomorphic attributes, cover bed stratigraphic composition (in particular, number of loess units and, where available, tephrochronology) or comparison with dated marine terraces from far-field locations, such as Barbados (Ghani, 1974; 1978). As a result, previous attempts at margin-wide terrace correlations and corresponding uplift estimates suffer large uncertainties.

The objectives of this investigation are to reassess the distribution of Pleistocene terraces along the south coast of the North Island, by employing up-to-date numerical dating and elevationmeasuring techniques of the raised shore platforms. These data will then be applied to quantifying uplift across this region. In this chapter, I present the distribution of terraces along the coast between Cape Terawhiti and Cape Palliser (Fig. 3.1), a distance of about $\sim 100 \mathrm{~km}$, together with stratigraphic observations of the terrace cover beds and Real-Time Kinematic (RTK) Global Navigational Satellite Systems (GNSS) elevations of the shore platforms. I use Optically Stimulated Luminescence (OSL) analysis to date the terraces - the first radiometrically-determined ages for the majority of the Pleistocene terraces along the south coast of the North Island. This data, combined, is used to correlate the terraces by age along the coast. 


\subsection{Background}

\subsubsection{Geology of the Pleistocene Marine Terraces}

Along the south coast of the North Island, Pleistocene shore platforms are cut into older bedrock of Triassic to Quaternary-aged deposits (see Fig. 3.1) (Begg \& Johnston, 2000). Between Tongue Point and Baring Head, basement rock consists of late Triassic to Early Jurassic greywackes of the Rakaia terrane. Further east, at Wharekauhau, the shore platform cut Pleistocene-aged fluvial deposits that have been correlated with the Te Muna and Ahiaruhe formations. Between Lake Ferry and Whangaimoana, shore platforms are cut into Pliocene mudstone, sandstone and conglomerate of the Onoke and Eketahuna Groups. Between Whangaimoana and Te Humenga Point, the terraces are inset into Miocene mudstone, sandstone and conglomerate of the Palliser and Soren Groups. At the easternmost field sites, between Te Humenga and Cape Palliser, basement rock consists of Cretaceous-aged greywackes of the Waioeka terrane.

The erosional shore platforms are unconformably overlain by both marine and non-marine deposits. Marine deposits typically consist of well sorted and well-rounded sands, pebbles and gravels that directly overly the shore platform, similar to modern-day beach deposits on this coastline. Younger, non-marine deposits are commonly alluvial in origin, or massive, homogeneous deposit of silt-size grains, suggesting an aerial deposition such as loess. Originating from the cliffs behind the terraces, angular and irregular-sized clasts of colluvium commonly form fans atop the aforementioned deposits and obscure the otherwise flat terrace treads.

\subsubsection{Previous Work}

The Pleistocene marine terraces along the south coast of the North Island of New Zealand were first described as 'high level gravel terraces' or 'rock shelves' in the earliest accounts of the geology of the region (e.g. Crawford, 1869; McKay, 1879); at Palliser Bay, McKay (1879) correctly identified them as ancient beaches, while Park (1909) suggested those between Cape Terawhiti and Baring Head were glacier platforms. In subsequent studies, the terraces were described in more detail, and attempts were made to correlate the marine terraces at Tongue Point and Baring Head (Cotton, 1912, 1921) and across New Zealand as a whole (Henderson, 1924) based on their elevation - using both height above sea level and the relative difference in elevation between terraces at the same site. 


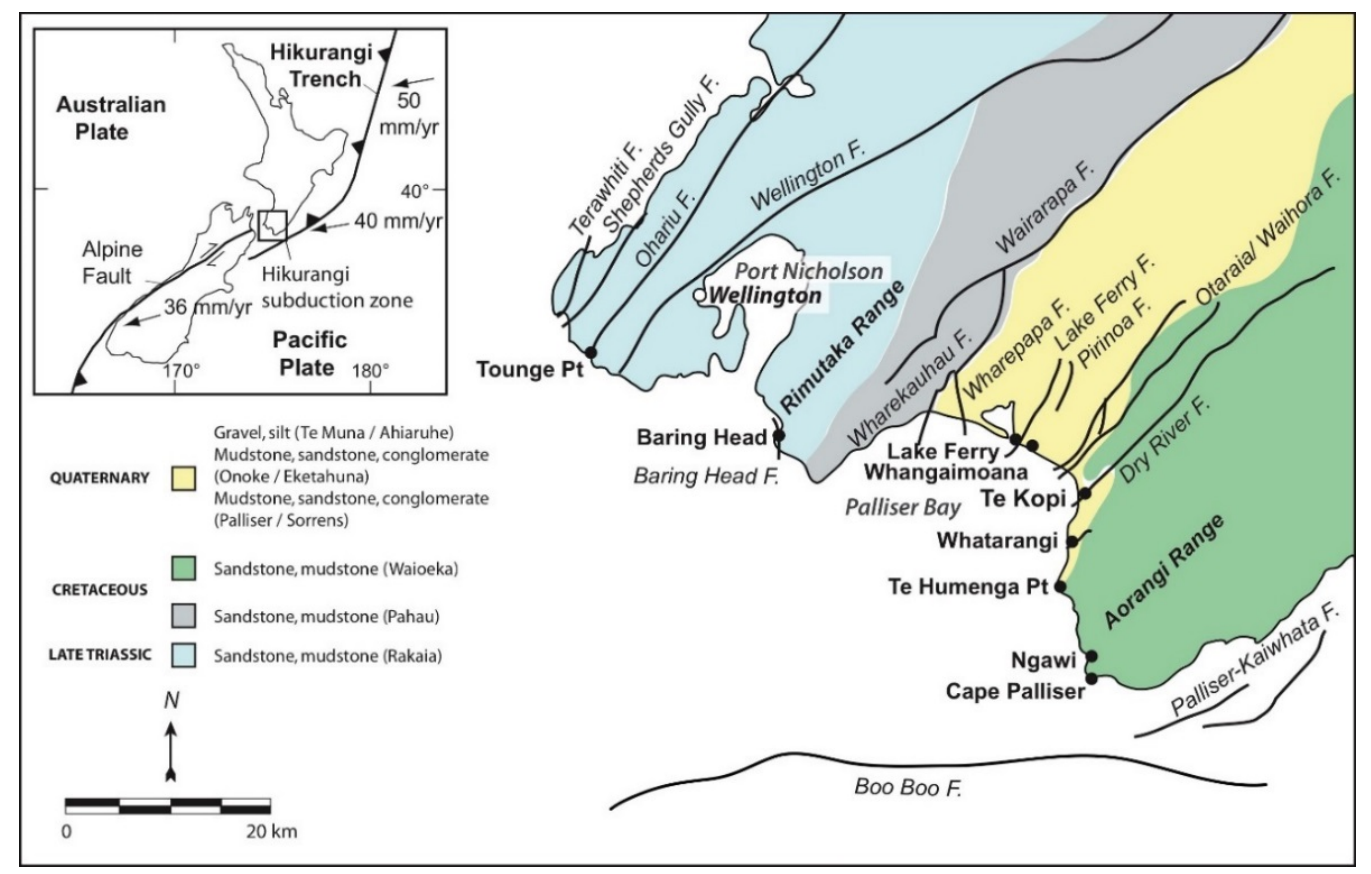

Figure 3.1. Southern North Island of New Zealand, with basement geology divided into tectonostratigraphic terranes, showing main upper plate faults. Also shown are sites referred to in this chapter. Insert - Tectonic setting of New Zealand.

A study by King (1930) of the 'raised beaches' along the south coast between Cape Terawhiti and Cape Palliser, as well as on the east coast of the North Island, was the first to recognise local differential uplift and regional tilting to the west. He concluded that terrace correlation based on elevation alone was futile, and instead used a combination of appearance (in particular, their degree of preservation) and cover bed stratigraphy. Along the south coast, King recognised six platforms that had formed at different times during the Pleistocene. Cotton $(1912,1916,1918,1921,1942,1952,1957)$ also found evidence for six 'multicycle shorelines of emergence' and discussed the influence of upper plate faulting (namely the Wellington and Wairarapa faults) on patterns of subsidence at Port Nicholson and Palliser Bay, and of relative uplift elsewhere along the south coast. One of the most obvious fault-offset marine terrace along the south coast, at Tongue Point, was first described by Grant-Taylor $(1963,1965)$. Heine (1974) revisited the terraces at Tongue Point and (incorrectly) dismissed previous suggestions of tilting and fault-offset, instead identifying five different-aged terraces based solely on their elevation.

The first attempts to assign numerical ages to the terraces was made by Ghani $(1974,1978)$, who investigated the uplifted marine benches at Palliser Bay from Wharekauhau to Cape Palliser, as well as along the east Wairarapa coast. Based on terrace elevation and cover bed stratigraphy, he identified four Pleistocene-aged terraces in this region. Ghani inferred ages for 
these based on radiometrically-dated coral reefs in Barbados (by Mesolella et al., 1969); from lowest in elevation to highest, their ages were estimated to be $80 \mathrm{ka}, 84 \mathrm{ka}, 100 \mathrm{ka}$ and $125 \mathrm{ka}$. Ota et al. (1981) examined the terraces west of Palliser Bay, between Cape Terawhiti and Baring Head. These terraces were correlated based on their degree of preservation and cover bed stratigraphy, and six Pleistocene-ages terraces were identified. They suggested that that the best-preserved terrace (the 'main terrace') along the coast formed during the 'main (high sea level) event' of the last interglacial stage, that being MIS 5e. Since these studies, the terraces have remained largely undated, the exception being those at Wharekauhau on the Palliser Bay coast. There, OSL dating of both marine and non-marine shore platform cover beds was recently undertaken by Schermer et al. (2009) as part of a detailed study of the Wharekauhau Fault system. Results from this study attribute ages of $71 \pm 8 \mathrm{ka}, 106 \pm 24 \mathrm{ka}$ and $127 \pm 20 \mathrm{ka}$ for marine deposits mantling the abandoned shore platform, collected at three different locations at Wharekauhau. These ages are consistent with results from an earlier study of fossil beetle fauna at Wharekauhau by Marra (2003). In that study, OSL dating was employed to constrain the age of bettle assemblages, found to overly the local shore platform, to MIS 5a - 5e.

\subsubsection{Marine Terrace Formation Processes}

Typical components of a marine terrace, as cited in this thesis, are summarised in Figure 3.2. The shore platform is the surface cut by coastal erosion processes at sea level, the sea cliff is the landward edge of the shore platform, and the intersection of these is the inner margin, shoreline, shoreline angle or strandline. The term marine terrace is used for the composite modern-day landform, comprising of the shore platform overlain by marine and non-marine cover sediments, and the terrace tread is the depositional top surface of the marine terrace.

Shore platforms develop at sea level as a result of sustained erosion and weathering of coastal bedrock and ensuing sea cliff retreat. Erosion can be due to several mechanical processes, including air compression in joints, water hammer (the impact of waves on the shore), abrasion by sand and rock fragments, and quarrying (the removal of large rock fragments by waves). Weathering can occur as a result of tidal wetting and drying, salt weathering, bioerosion and other biological influences (Trenhaile, 1987 and references therein). The formation of a shore platform is commonly due to a combination of both mechanical erosion and weathering, with the degree of each varying between sites, depending on local factors such as geological properties, in particular rock resistance, as well as wave energy and tidal elevation. Some field studies of contemporary shore platforms show that weathering dominates in some places (e.g. 
Stephenson \& Kirk, 2000). However, modelling of coastal processes shows that, in general, mechanical wave erosion is the principal contributor to shore platform development (Trenhaile, 2008).

When a shore platform is abandoned by the sea due to eustatic sea-level lowering, the mostly planar surface, and the sea cliff behind it, is stranded above the level of marine erosion processes and remains preserved in the landscape. At subsequent stillstands (generally highstands - warm climate periods such as interglacials or interstadials) a new, younger platform forms at a lower elevation (see Fig. 3.2). This process of terrace formation and abandonment, repeated, can yield a stepped pattern of terraces along the coast. Worldwide examples of preserved marine terrace sequences include those along the Huon Peninsula of New Guinea (Chappell, 1974; Chappell et al., 1996), at Cape Mendocino, California (e.g. Merritts \& Bull, 1989; Carver et al., 1994; Murray et al., 1996; Merritts, 1996), along the coasts of Chile (e.g. Nelson \& Manley, 1992; Jara-Munoz et al., 2015), coastal Japan (e.g. Fitch \& Scholz, 1971; Okumura, 1996; Matsu'ura et al., 2014; Matsu'ura, 2015) and coastal Barbados (Broecker et al., 1968; Matthews, 1973; Bard et al., 1990). On tectonically active coastlines, a shore platform is abandoned by a combination of sea-level lowering and tectonic uplift, and the resultant terraces remain preserved in the landscape so long as ensuing tectonic uplift continues to outpace the rate of eustatic sea level rise.

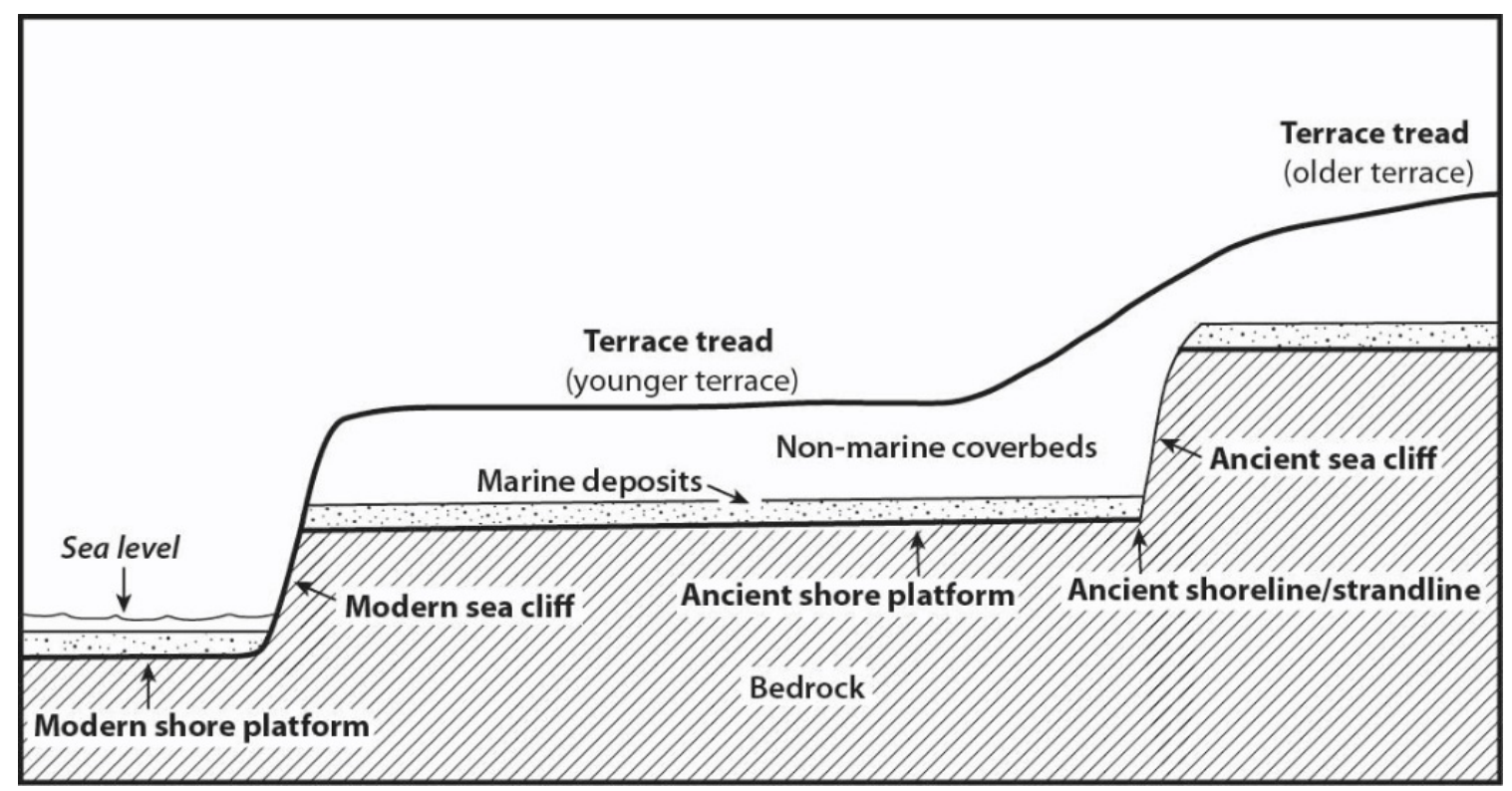

Figure 3.2. Schematic diagram showing basic features and corresponding terminology of marine terraces. Figure modified after Pillans (1990). Thickness of marine deposits and non-marine cover beds are illustrative only - they do not represent true thickness. 


\subsection{Methods}

\subsubsection{Terrace Distribution, Elevation and Geometry}

Pleistocene marine terraces were identified along the south coast of the North Island initially by reference to topographic maps (1:50,000, Land Information New Zealand (LINZ)) and by reference to previous terrace studies (Ghani, 1974, 1978; Ota et al., 1981). The terraces were then examined and mapped using vertical aerial photography (scale 1:16,000) as interpreted under stereoscopic vision. All accessible terraces were subsequently studied, mapped and surveyed in the field. Finally, the original desktop and field mapping was compared to more recently available LiDAR elevation data ( $1 \mathrm{~m}$ pixel size, vertical resolution $\pm 0.4 \mathrm{~m}$ ) obtained through LINZ.

The position (latitude, longitude and elevation) of points of interest for this study were collected over several surveys. I used a Trimble R8 GNSS RTK Surveying System, a Leica GPS System 500 and a MDL LaserAce 300 rangefinder to collect the elevation data.

For the majority of surveys, the base station was positioned on a nearby LINZ geodetic mark, whose location (latitude, longitude and ellipsoidal height) is published online by LINZ (http://www.linz.govt.nz/data/geodetic-services/search-for-geodetic-marks). LINZ assigns each geodetic mark with an 'order' - a classification based on the accuracy of the determined location in relation to the datum; a geodetic mark with an order of 0 is one that has been located most accurately. For our surveys, base stations were set up at geodetic marks whose classification ranged from order 1 to 5 , corresponding to maximum uncertainties of $\pm 15 \mathrm{~cm}$ for the horizontal component of the determined position, and $\pm 35 \mathrm{~cm}$ for the vertical component $(2 \sigma)$.

In some instances, the RTK base station was not positioned over a LINZ geodetic mark, but was instead placed over a marker peg. In this instance baselines were created to tie the survey data to a local geodetic mark.

The precision of elevation measurements using the devices mentioned above are typically no more than $\pm 1 \mathrm{~cm}$ for the horizontal component and $\pm 10 \mathrm{~cm}$ for the vertical $(2 \sigma)$. Additional uncertainties are introduced by the measurement of height above ground-level of the RTK rover device. This was mounted on to a back-pack and worn as the terraces were traversed, so one anticipates some fluctuation in height above ground-level as the device was walked around during the surveying process. I estimate this uncertainty to be no more than $\pm 30 \mathrm{~cm}(2 \sigma)$. 
Because the terraces and corresponding surveyed points are spread over the length of the south coast, the data were post-processed to ensure consistency between sites. A high precision orbit and geodetic parameter determination software (AUSPOS (http://www.ga.gov.au/scientifictopics/positioning-navigation/geodesy/auspos)) was used, which utilizes nearby International GPS Service (IGS) reference stations and a 'double difference' technique to compute the points into a common, universal datum. The coordinates of the IGS stations are constrained with uncertainties of $\pm 1 \mathrm{~mm}$ for horizontal and $\pm 2 \mathrm{~mm}$ for the vertical $(2 \sigma)$.

Shore platforms are seldom completely planar, as evident in the modern day shore platform along the south coast. Natural variations in elevation are due to, for example, concretions, sea stacks or channels. These introduce irregular local relief by up to several metres. As such, I consider the uncertainties introduced by instrumental accuracy and surveying techniques, as discussed above, lie within the natural variation of the shore platform, which I estimate to be \pm $3 \mathrm{~m}$. The measurement uncertainties are therefore discounted when considering the elevation of the shore platform and instead I assign a geologic uncertainty of $\pm 3 \mathrm{~m}(1 \sigma)$.

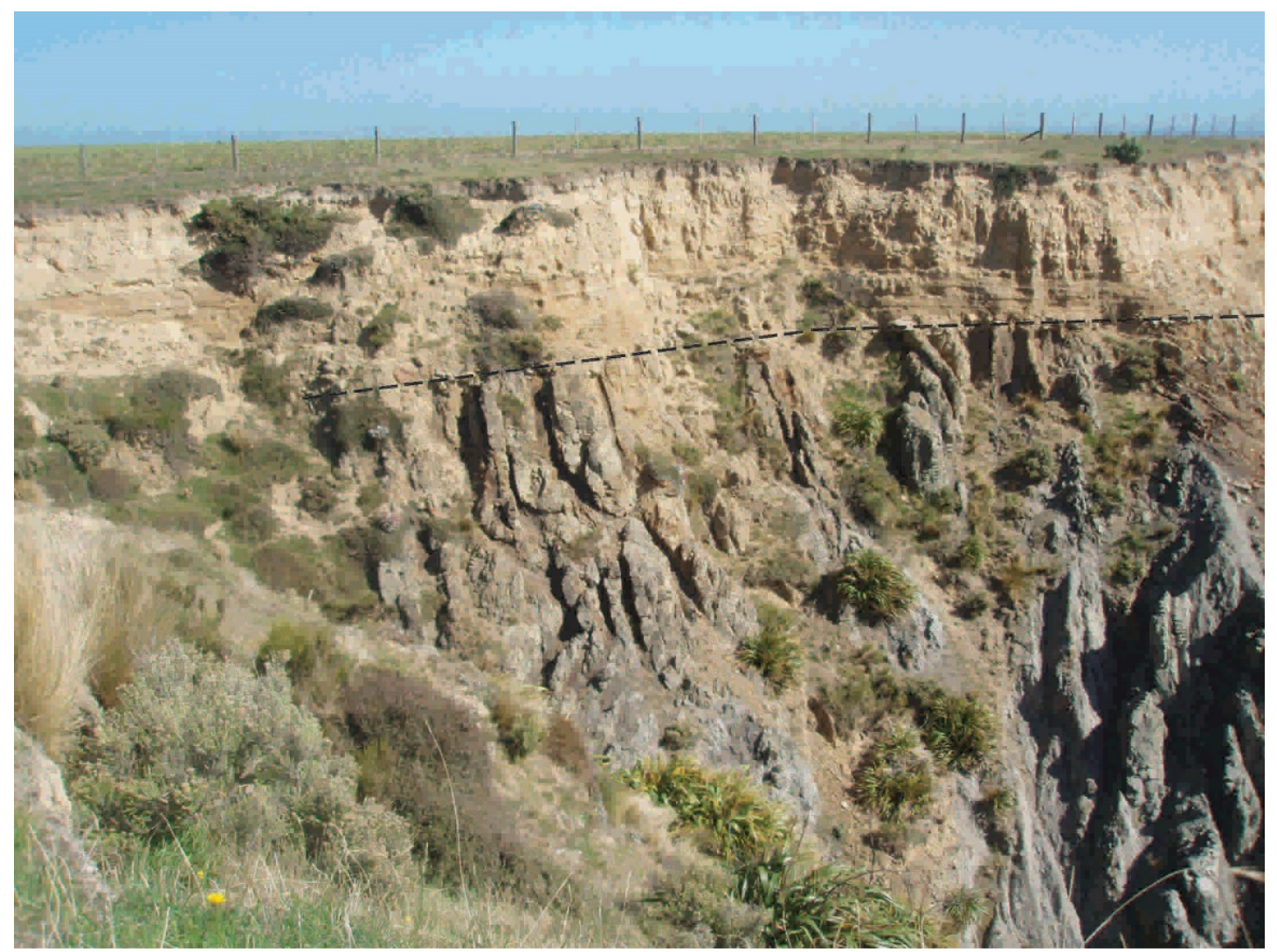

Figure 3.3. Pleistocene marine terrace, Te Humenga, Palliser Bay coast. The contact between the shore platform (dark grey-brown in photo) and the overlying sediment sequence of beach sands and gravels, and loess (light yellow-brown) is shown as a dashed line. 
Terrace altitude measurements were made at the shore platform, expressed as the stratigraphic boundary between the eroded bedrock and overlying sedimentary cover beds (Fig. 3.3). Special effort was made to find and survey this contact wherever it was exposed and accessible. Measurements were also made along the perimeter of the terrace (i.e. at the front or coastal edge, the sides, and back edge) atop of the terrace tread.

In order to correlate terraces across the south coast, I used the surveyed data points (latitude, longitude, elevation) to create a plane of best fit to represent the shore platform. Using Matlab, a plane was calculated at each site along the south coast where the marine terrace and shore platform was expressed continuously; if there was discontinuity due to incision by a drainage channel, or an obvious vertical offset in the terrace, then a plane of best fit was calculated for either side of that topographic interruption. This compartmentalisation was done so that a comparison could be made of the orientation of the plane on either side of the discontinuity, and therefore ensure that any changes in the elevation, orientation or shape of the shore platform are captured. The mean of the data points (assumed to be on the plane of best fit) and the corresponding normal vector were used to calculate the position coefficients of the best fit plane, and thus to fix its position and attitude. The accuracy of the resulting calculated plane depended on the number of elevation points used, whether there were outliers within the elevation dataset (for instance, measuring local lows due to channels, or highs due to sea stacks on the shore platform) and the spatial distribution of the data, and these varied between localities. To indicate how good a fit the calculated plane is to the original surveyed data, for each plane, I calculated the average distance of each surveyed elevation point to that plane, which I refer to as the residual of the fit - the smaller the residual, the better the plane fit. Details of the elevation dataset used to calculate each best fitting plane, the calculated orientation of the shore platform and residual values are presented in Appendix D.

\subsubsection{Terrace Stratigraphy}

Descriptions were made of the terrace cover bed stratigraphy at observed natural outcrops, especially where strata were considered to be well preserved and part of a complete (or near complete) sequence. I present stratigraphic descriptions of the terraces from where OSL samples were collected, as well as from locations where the terrace cover bed deposits were well exposed. See Figures 3.4 to 3.9 for summary descriptions at each site and Appendix E for detailed stratigraphic logs. 


\subsubsection{Terrace Age}

Optically Stimulated Luminescence techniques were employed to determine the age of the marine terraces along the south coast of the North Island. Sediment samples for analysis were collected from natural exposures, mainly in the coastal cliff faces, where safely accessible. Other exposures were found in vehicle tracks cut into the terraces. Before sampling, the outcrop was cut back to expose fresh material, and sediments were collected using a steel cylinder (60 $\mathrm{mm}$ diameter, $100 \mathrm{~mm}$ length) mounted on to a base unit which is hammered into the sediment, and then carefully removed and sealed with the sample inside.

Samples were collected from cover beds as close as possible above the eroded shore platform, targeting paleo-beach sediments whose deposition took place at the same time as the formation of the shore platform. Samples were also collected from younger deposits, higher in the stratigraphic sequence, in order to provide further minimum ages and to test that the OSL results fit within a coherent stratigraphic sequence. In total, 21 samples of silt/fine sand were submitted for OSL analysis of feldspar, targeting the 4-11 $\mu \mathrm{m}$ grain size (silt) fraction. Sample preparation and analysis was undertaken by the Luminescence Dating Facility at Victoria University of Wellington. All samples were analysed using the Multiple Aliquot Additive Dose technique (MAAD) (Aitken and Xie, 1992; Lang and Wagner, 1997). To achieve higher accuracy for older samples, or when the derived MAAD data were scattered, the Single Aliquot Regenerative (SAR) method (Murray \& Wintle, 2000) was used. Further details regarding the analytical methods, as well as a listing of OSL age results, are provided in Appendix A.

\subsection{Results}

The locations and elevations of the Pleistocene marine terraces are described below by field site from west to east. Elevations quoted are those of the shore platform unless otherwise stated, and spot elevation measurements are shown on the site summary figures (Fig. 3.4 to Fig. 3.9). The reader should assume all elevation values quoted have an uncertainty of $\pm 3 \mathrm{~m}(1 \sigma)$ for reasons described in the methodology. Coverbed stratigraphy descriptions and inferred depositional environments, as well as OSL ages are also presented. OSL ages quoted within the text are to $1 \sigma$ uncertainties unless otherwise stated.

\subsubsection{Tongue Point}

At the western-most field site, Tongue Point, I identified three Pleistocene terraces. From youngest to oldest, I name these TP-T1, TP-T2 and TP-T3 (Fig. 3.4). The Waiariki Stream cuts a channel through the terraces, and the NE-striking, dextral strike-slip Ohariu Fault, 
approximately follows the stream bed at this site. As with some previous studies (e.g. GrantTaylor, 1963; Ota et al., 1981) I see evidence for this fault vertically-offsetting the Tongue Point terraces, both at the shore platform and the terrace tread, as described below.

TP-T1 is preserved as three stacks at the mouth of Waiariki Stream. The stacks consist predominately of basement rock. On the central stack the coverbed deposits consist of a scattering of rounded to sub-angular beach pebbles $0.5-5.0 \mathrm{~cm}$ in diameter. No beach deposits were observed on two other stacks flanking either side of the current-day river to the east and west, which were covered by colluvium. The two westernmost shore platform remnants of TP$\mathrm{T} 1$ are $16 \mathrm{~m}$ above sea level, and are $9 \mathrm{~m}$ higher in elevation than the third, easternmost stack, due to past vertical movement on the fault.

TP-T2 is the main, coastal-most terrace at Tongue Point. To the west of Waiariki Stream and the Ohariu Fault, TP-T2 exists as a narrow bench along the coast, with shore platform exposures of $67-75 \mathrm{~m}$ in elevation. To the east, it dominates the topography, extending almost $700 \mathrm{~m}$ inland. Here, the shore platform is $27-48 \mathrm{~m}$ in elevation. Analysis of our elevation data shows that the western segment of the TP-T2 shore platform is dipping $8.8^{\circ}$ to the north. While this tilting may be due to deformation caused by movement on the Ohariu Fault, it warrants querying; not only is the shore platform steeply dipping, but it does so away from the currentday coast. A sensitivity analysis of each elevation point within the dataset used to calculate this shore platform orientation cannot be undertaken; there were only three shore platform exposures from which to survey elevations, and a plane of best fit cannot be calculated from the two points that remain. On this western side of the fault, the shore platform is overlain by well-rounded and well-sorted gravels. These gravels alternate with fine sand layers to form a cover bed of beach deposits $\sim 2 \mathrm{~m}$ thick. These beach deposits are in turn overlain by a $\sim 60 \mathrm{~cm}$ thick loess unit. In total, the thickness of cover beds on TP-T2 on the western side of Ohariu Fault is $\sim 2.5 \mathrm{~m}$. To the east of Waiariki Stream, outcrops of the TP-T2 shore platform show that it dips $7.8^{\circ}$ to the southwest. Here, it is not uncommon for the shore platform to outcrop at the surface towards the coastal edge of the terrace. Where preserved, the cover beds on this eastern side of the fault consist of well-rounded boulders, $50-70 \mathrm{~cm}$ in diameter, sitting directly on the shore platform. These are overlain by well-rounded beach pebbles, $0.5-2.0 \mathrm{~cm}$ in diameter. The total thickness of preserved cover beds on the eastern half of TP-T2 is typically $\sim 1 \mathrm{~m}$. Two OSL samples from a fine beach sand deposit $1.3 \mathrm{~m}$ above the shore platform of TP$\mathrm{T} 2$ to the west of Waiariki Stream, yielded ages of $110.0 \pm 10.8 \mathrm{ka}$ and $125.9 \pm 17.1 \mathrm{ka}$ (TP 01 and TP 02 respectively). A third sample collected within a loess unit a further $60 \mathrm{~cm}$ above the aforementioned samples, provides an OSL age of 19.0 $\pm 1.1 \mathrm{ka}$ (TP 03) (see Appx. E Fig. E1). 

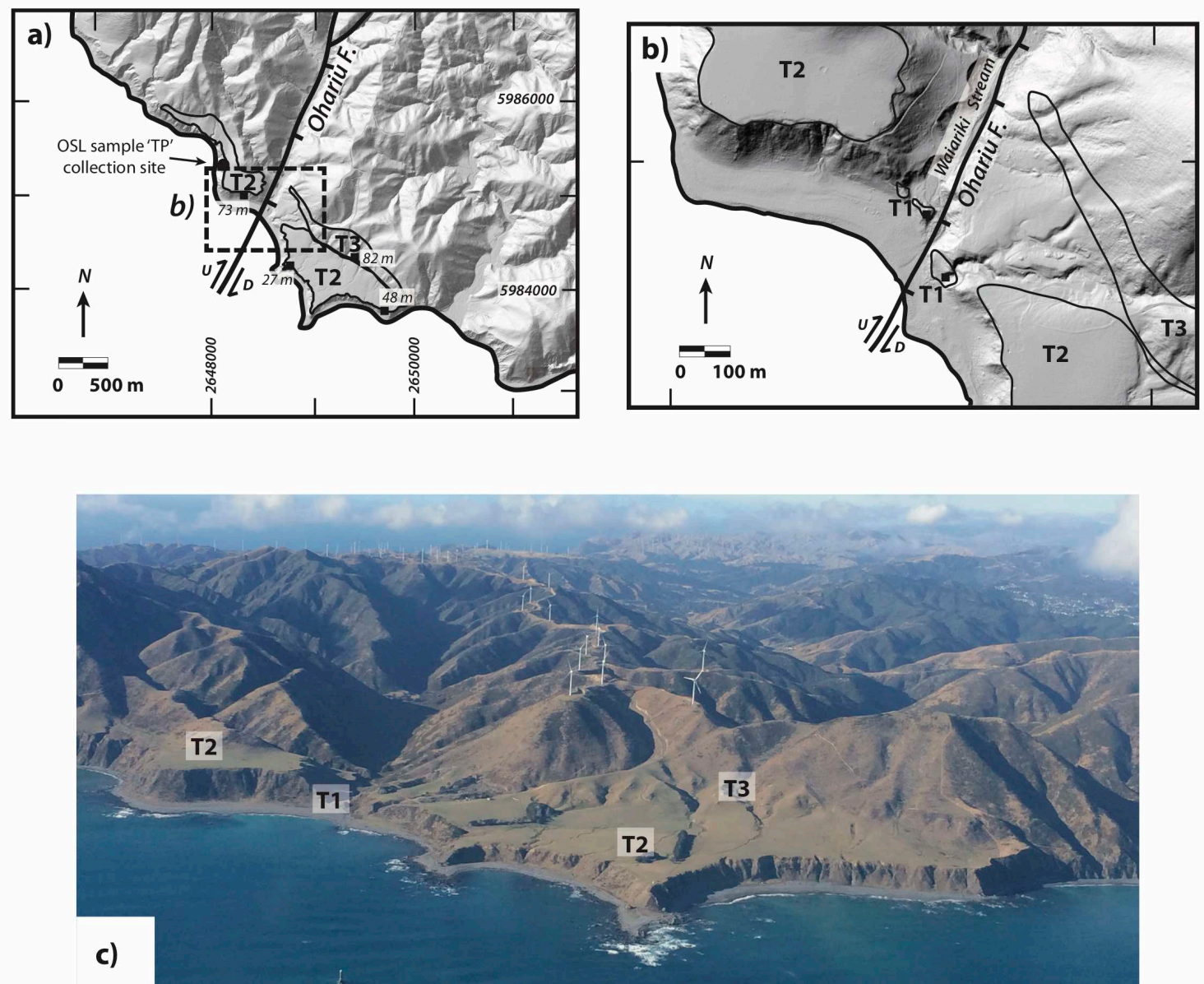

d)

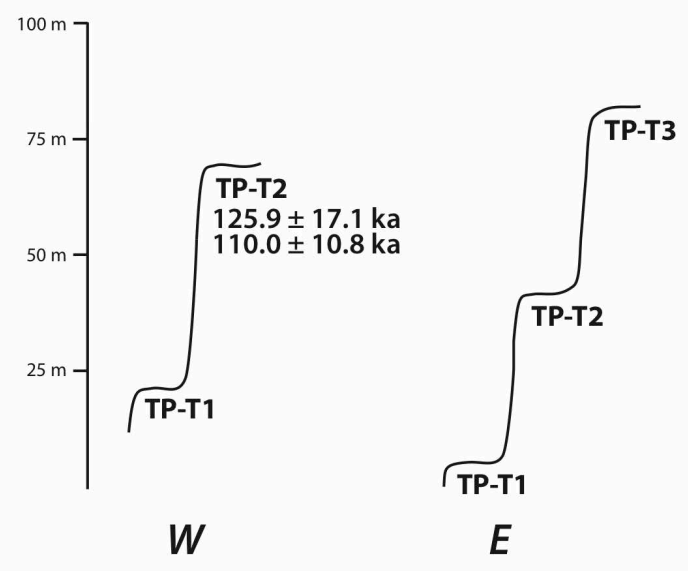

e) ' $T P$ '

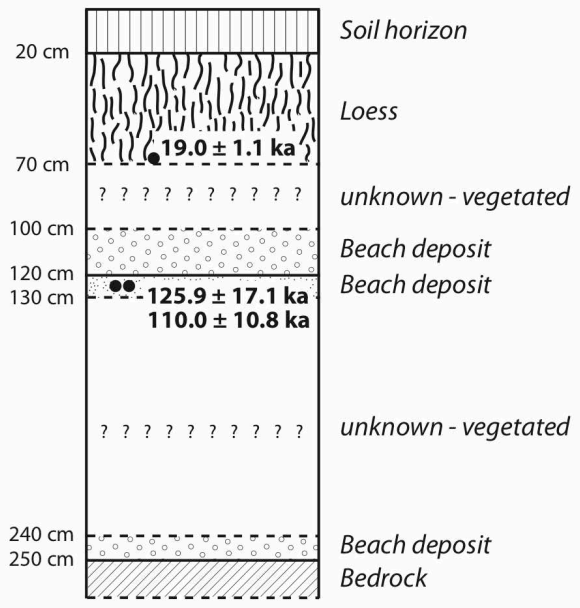

Figure 3.4. Tongue Point summary: a) and b) terrace maps showing fault location and OSL sample collection site, on LiDAR backdrop (LiDAR courtesy GWRC); c) aerial photograph of Tongue Point taken looking towards the northeast, with terraces labelled; d) terrace elevation profiles for both west and east of the Ohariu Fault; e) stratigraphic section exposed at the 'TP' OSL collection site (samples TP 01, TP 02 and TP 03). All terraces labelled in the figure are referred to with the prefix 'TP' (for Tongue Point) in the text. 
Remnants of a third, older terrace, TP-T3, are also preserved at Tongue Point, albeit poorly and only to the east of Waiariki Stream. The once continuous surface of this terrace has since been variably dissected to form a hummocky strip. Only a few shore platform exposures were identified, within drainage channels that dissect the terrace, at elevations between 79-84 m. Here, a scant scattering of re-worked pebbles were found directly overlying the shore platform. These are rounded to sub-angular, $0.5-4.0 \mathrm{~cm}$ in diameter, and resemble beach deposits.

\subsubsection{Baring Head}

Baring Head is located at the south-eastern headland of Wellington Harbour. Here, I mapped the terraces from Fitzroy Bay, across the Wainuiomata River, to the Orongorongo River. Six marine terraces were identified - from youngest to oldest I refer to these as BH-T1 to BH-T6 (Fig. 3.5). The NW-striking Baring Head Fault offsets the main terrace, BH-T1, at this site, at both the shore platform and terrace tread, as has been documented previously (Ota et al., 1981). I also mapped offsets of the shore platform by a second fault further to the east, between the Wainuiomata and Orongorongo rivers. This previously-mapped but otherwise un-named fault had not been reported in earlier Baring Head terrace studies.

Terrace BH-T1 is the most prominent terrace at Baring Head. The shore platform of this terrace is commonly exposed in the modern-day coastal cliffs, at elevations of $40 \mathrm{~m}$ near Fitzroy Bay in the east to $120 \mathrm{~m}$ at its westernmost preserved location at the mouth of the Orongorongo River. The Baring Head Fault vertically offsets BH-T1 at both the shore platform and terrace tread. The shore platform elevation measurements show that it has been uplifted by $\sim 13 \mathrm{~m}$ to the west relative to the eastern side of the fault. In addition, another un-named fault to the east of Wainuiomata River also vertically offsets the BH-T1 shore platform, by $\sim 7 \mathrm{~m}$ uplifted to the east. This offset can also be observed at the terrace tread, however it is somewhat obscured by colluvium. There were too few shore platform elevation measurements on the western side of the Baring Head Fault, and on the eastern side of the un-named fault from which to determine an attitude of the BH-T1 shore platform there. However, analysis of the elevation data between these two faults shows that this shore platform dips $3^{\circ}$ towards the southwest.

The cover beds of BH-T1 were observed along the coastal cliffs. They consist of beach deposits up to $\sim 15 \mathrm{~m}$ thick, typically consisting of $\sim 3 \mathrm{~m}$ of well-rounded and moderately well-sorted cobbles $(<15 \mathrm{~cm})$. These are overlain by $\sim 12 \mathrm{~m}$ of well-rounded, well-sorted sand deposits, that generally fine upwards with alternating layers of medium sand-sized grains to pebbles $(<$ $5 \mathrm{~mm}$ ) near the top of the sequence (see Appx. E Fig. E2). A sample collected from these sands, $2.5 \mathrm{~m}$ above the shore platform, yielded an OSL age of $55.5 \pm 8.7 \mathrm{ka}$ (BAR 01). 
Remnants of the second-highest Pleistocene terrace, BH-T2, are exposed at Baring Head on the western side of Wainuiomata River only. The shore platform of this terrace is $34 \mathrm{~m}$ higher in elevation than that of BH-T1. The coverbed deposits observed on this shore platform are 1.5-2 m thick (see Appx. E Fig. E3). The beach deposits consist of well-rounded clast supported gravels in layers $15-20 \mathrm{~cm}$ thick, interlayered with sub-rounded pebbles up to $8 \mathrm{~cm}$ with a matrix of fine pebbles. These are well-cemented and therefore not suitable for OSL dating.

The next oldest terrace at Baring Head, BH-T3, is 10 m higher than that of BH-T2. Only a thin deposit of cover bed was preserved on this terrace, consisting of $\sim 80 \mathrm{~cm}$ of well-rounded, clast supported beach gravels. Again, these deposits were too well-cemented to suit OSL dating.

A small exposure of shore platform and associated cover beds was found at a vehicle track cutting between the Wainuiomata River and Orongorongo River. Here, at an elevation of 173 $\mathrm{m}$, the shore platform is overlain by beach deposits consisting of a $\sim 50 \mathrm{~cm}$ layer of wellrounded, poorly sorted pebbles and cobbles $<30 \mathrm{~cm}$ in diameter. This is overlain by a $\sim 1 \mathrm{~m}$ thick unit of well-sorted gravels on which has been deposited a $\sim 6$ m thick unit of sand, also interpreted as beach deposits. A subangular gravel colluvium tops the coverbeds at this exposure. This terrace is $63 \mathrm{~m}$ higher in elevation that the BH-T1 terrace which is the sole terrace preserved below it at this site. Based on this difference in elevation, I interpret this to be a remnant of $\mathrm{BH}-\mathrm{T} 3$ as expressed at this site.

Two samples taken from within the marine sand layer $3 \mathrm{~m}$ and $4 \mathrm{~m}$ above the BH-T3 shore platform (see Appx. E Fig. E4), yielded OSL ages of $161.3 \pm 23.9 \mathrm{ka}$ and $145.8 \pm 14.5 \mathrm{ka}$ (samples BARHD 02 and BARHD 03 respectively). This terrace is likely offset by the unnamed fault which is projected to cross through this area (see Fig. 3.5), however the terrace is not expansive enough to see this offset either at an outcrop exposure or as a surface expression.

The next oldest preserved shore platform on the eastern side of Wainuiomata River, that of BH$\mathrm{T} 4$, is $215-280 \mathrm{~m}$ above sea level. Along the coastal edge of this terrace, the cover beds have been removed and the shore platform outcrops at the surface. The shore platform is also exposed where this terrace is vertically offset by the un-named fault. Where they remain, cover bed deposits consist of $\sim 20 \mathrm{~cm}$ of beach gravels directly on the shore platform, which in turn are overlain by $\sim 20 \mathrm{~cm}$ of silts interpreted to be loess. The un-named fault clearly offsets this terrace at the tread, by $\sim 60 \mathrm{~cm}$. Based on field observations and measurements of tread elevation, I interpret that this terrace is also preserved to the west of Wainuiomata River, as the highest elevation point there, although there were no shore platform exposures at that site to confirm this interpretation. 

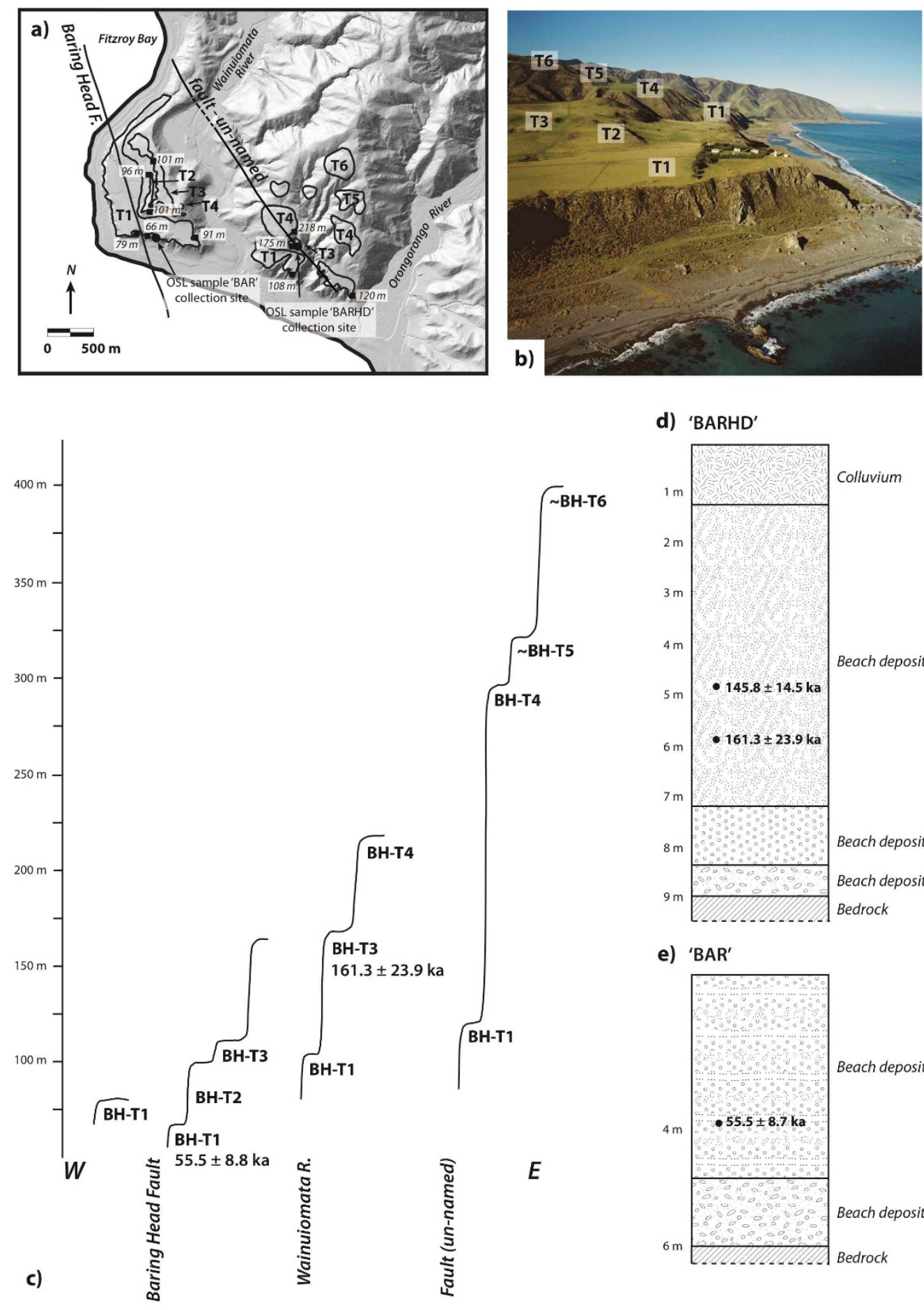

d) 'BARHD'

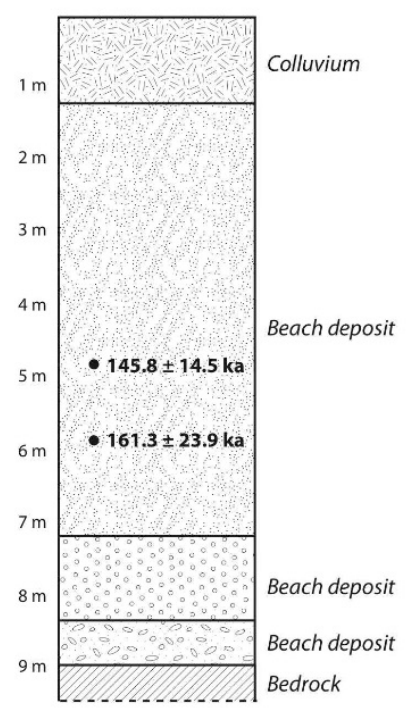

e) 'BAR'

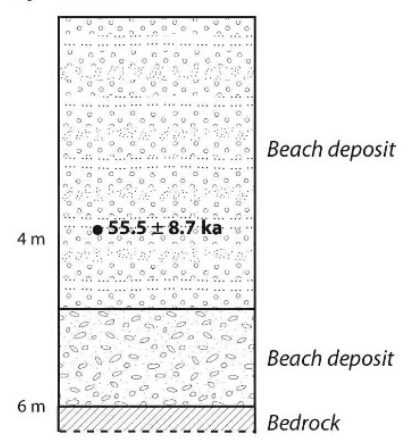

Figure 3.5. Baring Head summary: a) terrace maps showing fault locations and OSL sample collection site, on LiDAR backdrop (LiDAR courtesy GWRC); b) aerial photograph of Baring Head taken looking to the east, with terraces labelled. Photo taken by L. Homer - GNS Science Visual Media Library VML ID: 9025, Catalogue Number: 1163/7; c) terrace elevation profiles for west of the Baring Head fault, between the Baring Head Fault and Wainuiomata River, between the river and the un-named fault, and east of the un-named fault d) stratigraphic section exposed at the OSL collection site (samples BARHD 01 and BARHD 02); e) stratigraphic section exposed at the OSL collection site (sample BAR01). All terraces labelled in the figure are referred to with the prefix 'BH' (for Baring Head) in the text. 
Terrace BH-T5 with a tread elevation of $280-320 \mathrm{~m}$, and BH-T6 whose tread is $400 \mathrm{~m}$ above sea level, are preserved to the east of Wainuiomata River only. No exposures of the shore platform or beach deposits were found for these features; they have only been interpreted as terraces based on the flat expanse of local topography.

\subsubsection{Wharekauhau}

The Wharekauhau site spans $\sim 4.5 \mathrm{~km}$ of coast between Wharekauhau Stream and Lake Onoke, in Palliser Bay. Here, one marine terrace was identified, WH-T1 (Fig. 3.6). Two faults have previously been mapped as passing through this area - the Wharepapa and Wharekauhau faults. A detailed investigation of these faults including mapping, stratigraphic descriptions and luminescence analysis of strata through this region, was undertaken by Schermer et al. (2009). That investigation presented evidence to show that the Wharekauhau thrust fault offsets the shore platform and overlying beach deposits where it crosses them. OSL dating of these beach deposits by Schermer et al. (2009) showed them to be $71-127 \mathrm{ka}$ in age. The younger coverbeds further up in the stratigraphic sequence, dated as $<20$ ka by Schermer et al. (2009), are not offset by the fault. The fault offsets were observed by Schermer et al. (2009) in outcrops away from the coast (namely in Te Mahonge and Wharekauhau stream); they were not evident at the coastal-most edge of the marine terraces.

The WH-T1 terrace extends almost $3 \mathrm{~km}$ inland from the coast. Where exposed, in the coastal cliffs, the shore platform elevation of WH-T1 is 9-15 m above sea level, and elevation data analysis shows it dipping to the south-west by $0.2^{\circ}$. The shore platform is overlain by up to $\sim 8$ $\mathrm{m}$ of beach deposits, namely medium grained sands with lenses of well-rounded gravels. The beach deposits are overlain by a unit of interbedded mud and silt with gravel lenses, up to $\sim 7$ $\mathrm{m}$ thick along coastal exposures. These in turn are overlain by a unit consisting predominantly of coarse fluvial gravels, up to $10 \mathrm{~cm}$ in diameter, with a total unit thickness of $\sim 7 \mathrm{~m}$. Samples collected near Wharepapa Stream from the sandy beach deposits, at $20 \mathrm{~cm}$ and $50 \mathrm{~cm}$ above the contact with the shore platform, yielded minimum ages of $206.9 \pm 16.6 \mathrm{ka}$ and $198.9 \pm 18.9$ ka (samples Wpapa 01 and Wpapa 02 respectively) (see Appx. E Fig. E5), for the formation of the WH-T1 shore platform.

\subsubsection{Lake Ferry - Te Kopi}

In Palliser Bay, to the east of Lake Onoke, the coastal area between Lake Ferry and Te Kopi is dominated by one well-preserved terrace, PB-T1 (Fig. 3.7). Several active reverse faults have been mapped in this region (Begg \& Johnston, 2000); from west to east they are the Turanganui 
Fault, the Pirinoa Fault, the Otaraia Fault, the Waihora Fault and the Dry River Fault. Based on field observations and shore platform elevation data, only the Pirinoa Fault offsets the PB-T1 terrace at both the shore platform and terrace tread, by $\sim 2 \mathrm{~m}$ uplifted to the west. A previously identified but un-named fault offsets PB-T1 at the shore platform, by $\sim 1.5 \mathrm{~m}$, just to the east of Lake Ferry. This fault does not offset the beach deposits above this shore platform and is therefore considered inactive.

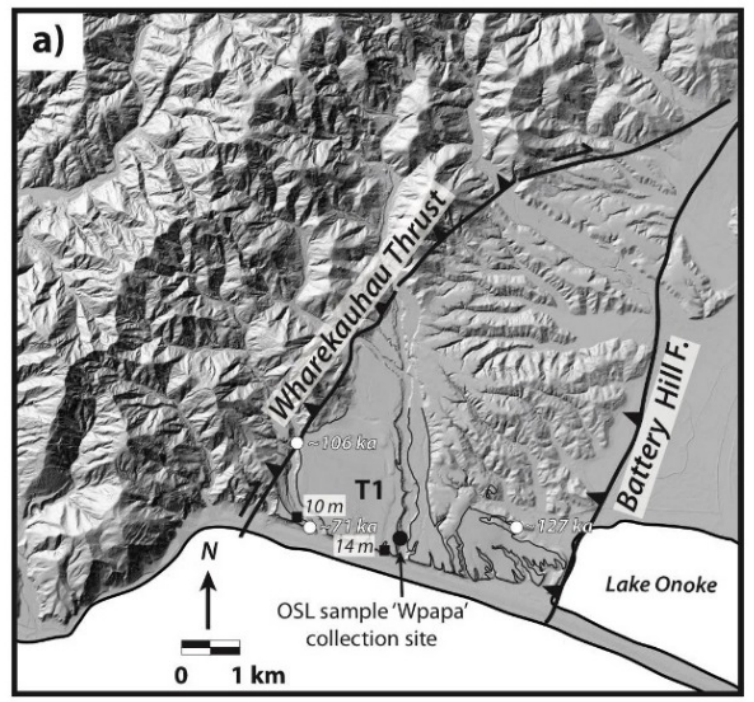

b)

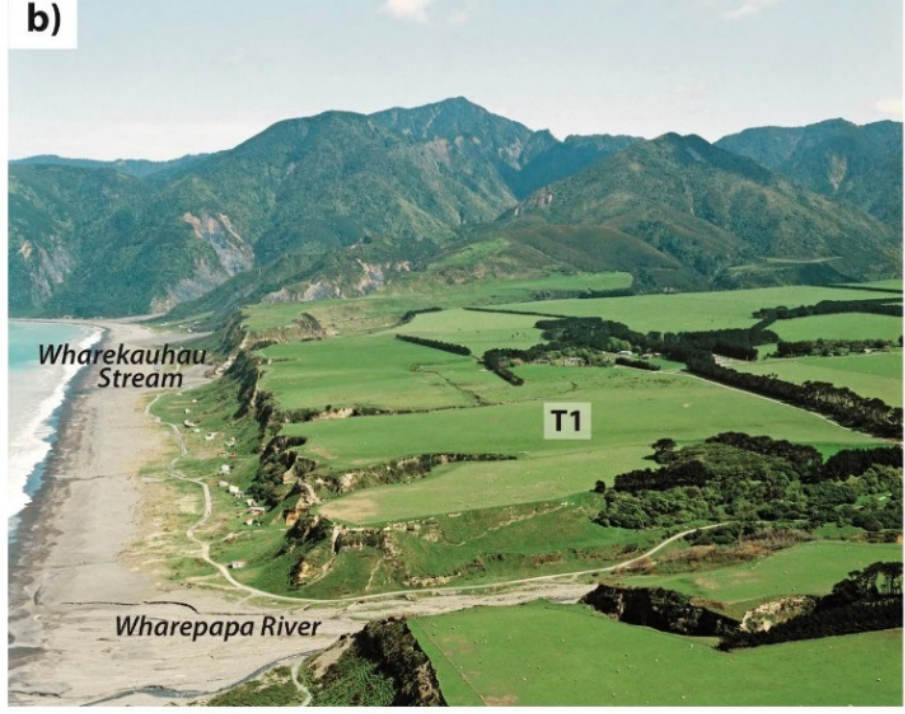

c) 'Wpapa'

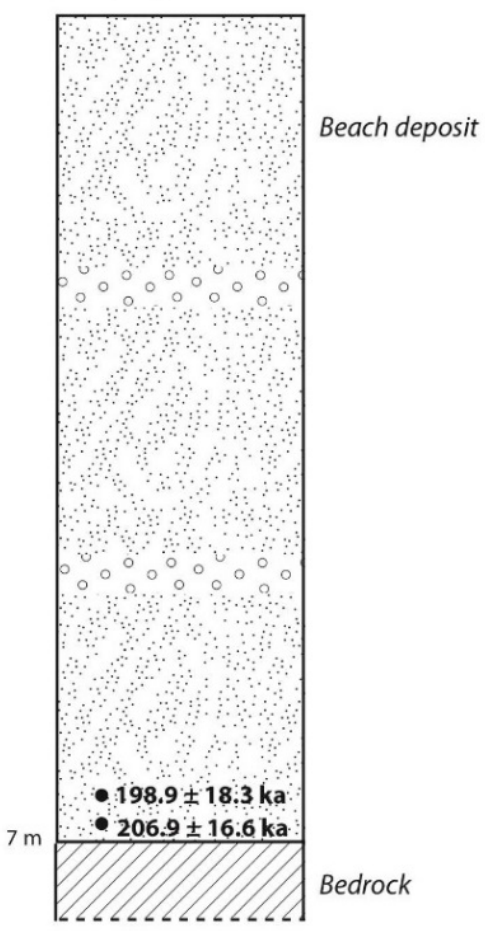

Figure 3.6. Wharekauhau terrace summary: a) terrace map showing fault locations and OSL sample collection site (black dot - this study; white dots and dates from Schermer et al., 2009), on LiDAR backdrop (LiDAR courtesy GWRC); b) aerial photograph of Wharekauhau taken looking to the west, with terrace labelled. Photo taken by L. Homer - GNS Science Visual Media Library VML ID: 9171, Catalogue Number: 23865/8; c) stratigraphic section exposed at the OSL collection site 'Wpapa' (samples Wpapa 01 and Wpapa 02). Terrace labelled in the figure is referred to with the prefix 'WH' (for Wharekauhau) in the text. 
The PB-T1 shore platform is $27 \mathrm{~m}$ in elevation at Lake Ferry, increasing in elevation to the east and reaching $88 \mathrm{~m}$ near Te Kopi. Between these locations, the terrace extends up to and beyond $2 \mathrm{~km}$ inland. Because of the offset by the Pirinoa Fault, the shore platform attitude was examined separately on either side of this structure. Analysis of shore platform elevation data from the western, Lake Ferry side of the fault shows PB-T1 dipping gently at $\sim 0.7^{\circ}$ towards the west. East of the fault, the shore platform dips at $\sim 0.6^{\circ}$ in the same direction. Along this stretch
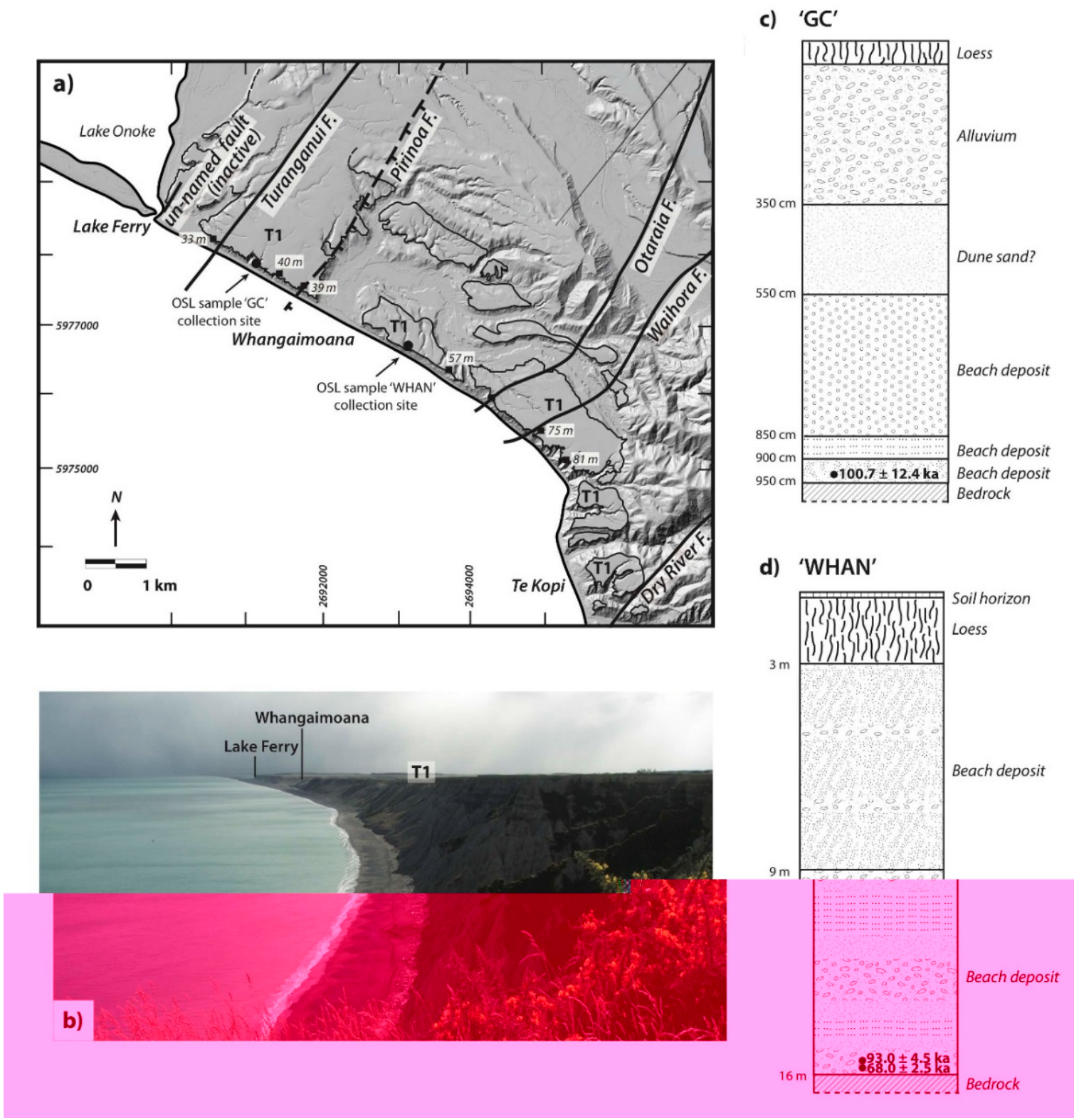

d) 'WHAN'

Figure 3.7. Lake Ferry - Te Kopi summary: a) terrace maps showing fault locations and OSL sample collection site, on LiDAR backdrop (LiDAR courtesy GWRC); b) photograph of Lake Ferry - Te Kopi terraces taken from near Te Kopi, looking to the west, with terraces labelled; c) stratigraphic section exposed at OSL collection site (samples WHAN 01 and WHAN 02); d) stratigraphic section exposed at the OSL collection site (sample GC 01). All terraces labelled in the figure are referred to with the prefix 'PB' (for Palliser Bay) in the text. 
of coast, cover beds of PB-T1 are 10-30 m thick, generally increasing in thickness towards the east, and vary laterally in composition along the coast. Along Whangaimoana Beach, the cover beds typically consist of a basal unit, $\sim 6 \mathrm{~m}$ thick, of well-rounded beach sand, pebbles and gravels. These are overlain by $\sim 3 \mathrm{~m}$ of coarse fluvial gravels ( $<10 \mathrm{~cm}$ in diameter), which in turn is overlain by a $\sim 3$ m thick unit of loess.

Terrace PB-T1 was sampled at two sites along the coast. At both sites, samples were taken from beach sand layers within $35 \mathrm{~cm}$ of the shore platform. OSL analysis yields an age of $100.7 \pm$ $12.4 \mathrm{ka}(\mathrm{GC}-1 \mathrm{a})$ from a site to the west of Whangaimoana Beach (see Appx. E Fig. E6). From a site to the east of Whangaimoana Beach, two ages were obtained, 93.0 $\pm 4.5 \mathrm{ka}$ and $68.0 \pm$ $2.5 \mathrm{ka}$ (WHAN-01 and WHAN-02 respectively) (see Appx. E Fig. E7). However, the OSL analysis and resulting measurement data of the sample that yielded the younger age was considered less reliable (see Appendix A), so $93.0 \pm 4.5 \mathrm{ka}$ is a more accurate representation of the age of the shore platform at this site.

\subsubsection{Washpool/Whatarangi}

At the eastern side of Palliser Bay, the Washpool/ Whatarangi field site extends from the Purangirua Stream (just south of Te Kopi) to Washpool Station and the Makotukutuku Stream. There are two marine terraces preserved at Washpool/Whatarangi - a lower terrace, WW-T1, and a second, higher and older terrace, which I have named WW-T2 (Fig. 3.8). The Whatarangi Fault, a reverse fault, has been mapped through the area (e.g. Begg \& Johnston, 2000).

The shore platform of WW-T1 is $65-82 \mathrm{~m}$ in elevation, dipping at $\sim 1.5^{\circ}$ towards the northwest. The shore platform is in places overlain by up to $\sim 30 \mathrm{~m}$ of cover beds, typically consisting of a basal layer of $\sim 10 \mathrm{~m}$ of beach gravels and sands that are overlain by loess and colluvium. The thickness of the latter varies from site to site but is usually $\sim 2 \mathrm{~m}$. Samples were collected from the cover bed deposits of WW-T1 for OSL analysis, two of which were from beach sands 40 $\mathrm{cm}$ above the shore platform. These provided an age of $63.5 \pm 6.0 \mathrm{ka}$ and $68.8 \pm 8.8 \mathrm{ka}$ (samples WSHP 01 and WSHP 02 respectively). A third sample, collected from the sand unit $2 \mathrm{~m}$ above the shore platform, yielded an age of $56.1 \pm 2.3 \mathrm{ka}$ (WSHP 03). A fourth sample, from within the overlying loess, gave an age of $39.9 \pm 2.0 \mathrm{ka}$ (see Appx. E Fig. E8).

A second, higher, terrace, WW-T2, is also preserved at Washpool/Whatarangi. A small remnant of this terrace is preserved at the coast, adjacent to WW-T1 just north of Washpool Station and Makotukutuku Stream. Here, a sudden increase in tread elevation reflects a similar increase in the shore platform below, with the WW-T2 shore platform being $\sim 100 \mathrm{~m}$ elevation, $\sim 20 \mathrm{~m}$ higher than WW-T1. Based on its geomorphic expression, I infer WW-T2 is also preserved 

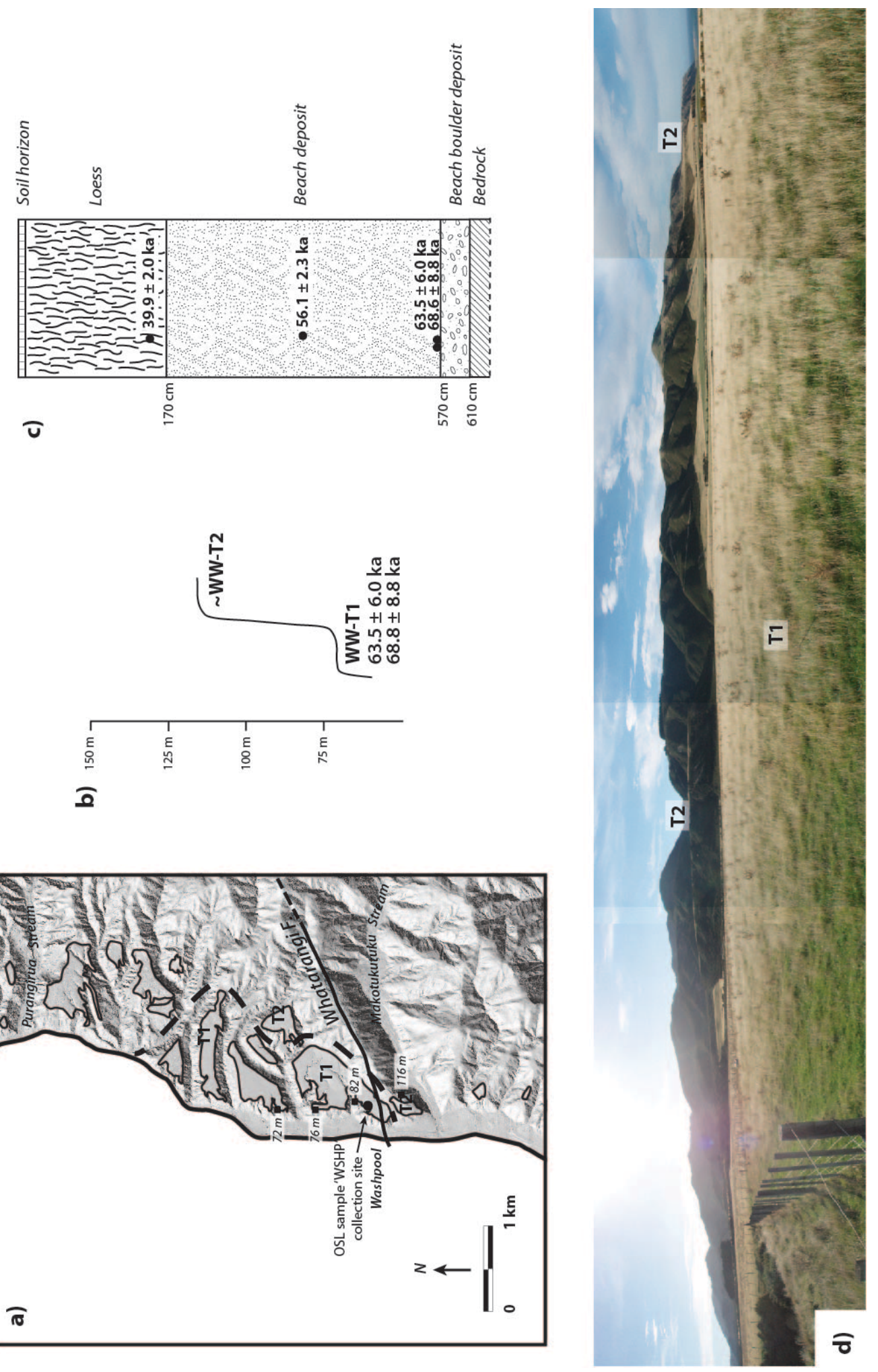

Figure 3.8. Washpool/Whatarangi summary: a) terrace map showing fault location and OSL sample collection site, on LiDAR backdrop (LiDAR courtesy GWRC); b) terrace elevation profile; c) stratigraphic section exposed at OSL collection site (samples WSHP 01, 0203 and 04; d) panoramic photograph with terraces labelled. All terraces labelled in the figure are referred to with the prefix 'WW' (for Washpool/Whatarangi) in the text. 
behind WW-T1, as its relatively flat tread continues from the coast inland, encircling WW-T1, and around to the coast again north of Whatarangi Stream. However, no shore platform exposures or beach deposits associated with the inland extent of WW-T2 were found to support this interpretation.

The NE-striking Whatarangi Fault has previously been mapped through this area (e.g. Begg \& Johnston, 2000). Ghani (1974) suggested that this fault offsets the lower terrace, east-side-up at Washpool/Whatarangi; his conclusion was that our coastal WW-T2 remnant is instead the same as the adjacent WW-T1, only uplifted by the fault. The Whatarangi Fault is indeed in the vicinity of this change in shore platform and terrace tread elevation. However, I conclude the Whatarangi Fault is expressed solely by a change in basement lithology, as exposed in the shore platform, just to the north of the change in terrace elevation, and that the fault does not offset the shore platform or beach deposits above.

\subsubsection{Te Humenga Point - Cape Palliser}

At the eastern end of the Palliser Bay coast, the terraces south of Makotukutuku Stream to just south of Ngawi are here referred to as the Te Humenga Point - Cape Palliser terraces. One Pleistocene terrace is preserved here; TH-T1 (Fig. 3.9).

Based on aerial photo interpretation and field observations, TH-T1 is the main terrace between Te Humenga Point and Cape Palliser. Moreover, surveyed elevations on both the terrace tread and the shore platform show that it is continuous along this stretch of coast. Analysis of shore platform elevation points between Te Humenga Point and Cape Palliser show the TH-T1 shore platform rising from $116 \mathrm{~m}$ in elevation at Makotukutuku Stream, to 141 at Te Humenga, and $213 \mathrm{~m}$ in elevation at its easternmost extent above the town of Ngawi, and tilting 2.5-2.9 towards the west. The cover bed sequence of this terrace consists of up to $4 \mathrm{~m}$ of beach deposits - generally alternating layers of rounded to sub-rounded fine to coarse sand and gravel, which directly overly the shore platform. These beach deposits are overlain by $\sim 2 \mathrm{~m}$ of massive silt, within which were identified at least two loess units, marked mainly by a change in colour the older unit being orange, and the younger unit being grey.

Two samples taken from a thick coarse sand deposit, at $2 \mathrm{~cm}$ and $20 \mathrm{~cm}$ above the TH-T1 shore platform, yielded ages of $126.7 \pm 10.0 \mathrm{ka}$ and $87.1 \pm 6.3 \mathrm{ka}$ (PAL 3A and PAL 3B respectively) for this beach deposit. A sample taken from a silt deposit directly overlying the sand gives an age of $86.0 \pm 4.2 \mathrm{ka}$ (PAL 4) (see Appx. E Fig. E9). OSL dating of well-rounded coarse sand with a silty matrix taken from $\sim 15 \mathrm{~cm}$ above the shore platform near Ngawi, gives an age of $114.5 \pm 10.0 \mathrm{ka}$ (NWI 1B) for beach unit overlying the shore platform. Silt from within the 


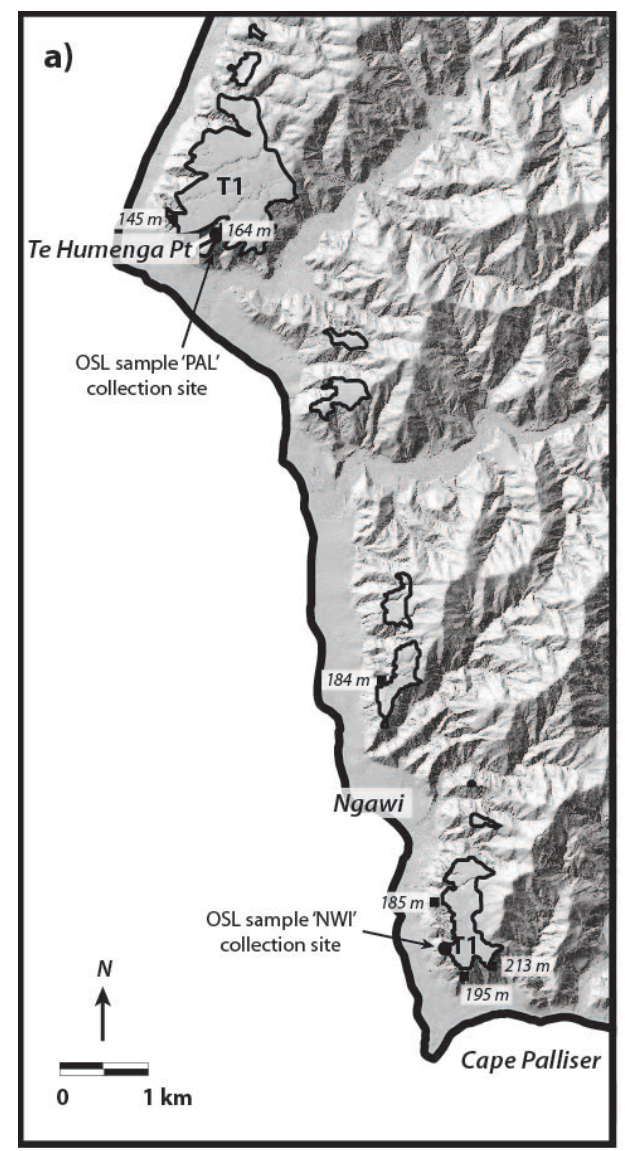

b) ' $P A L$ '
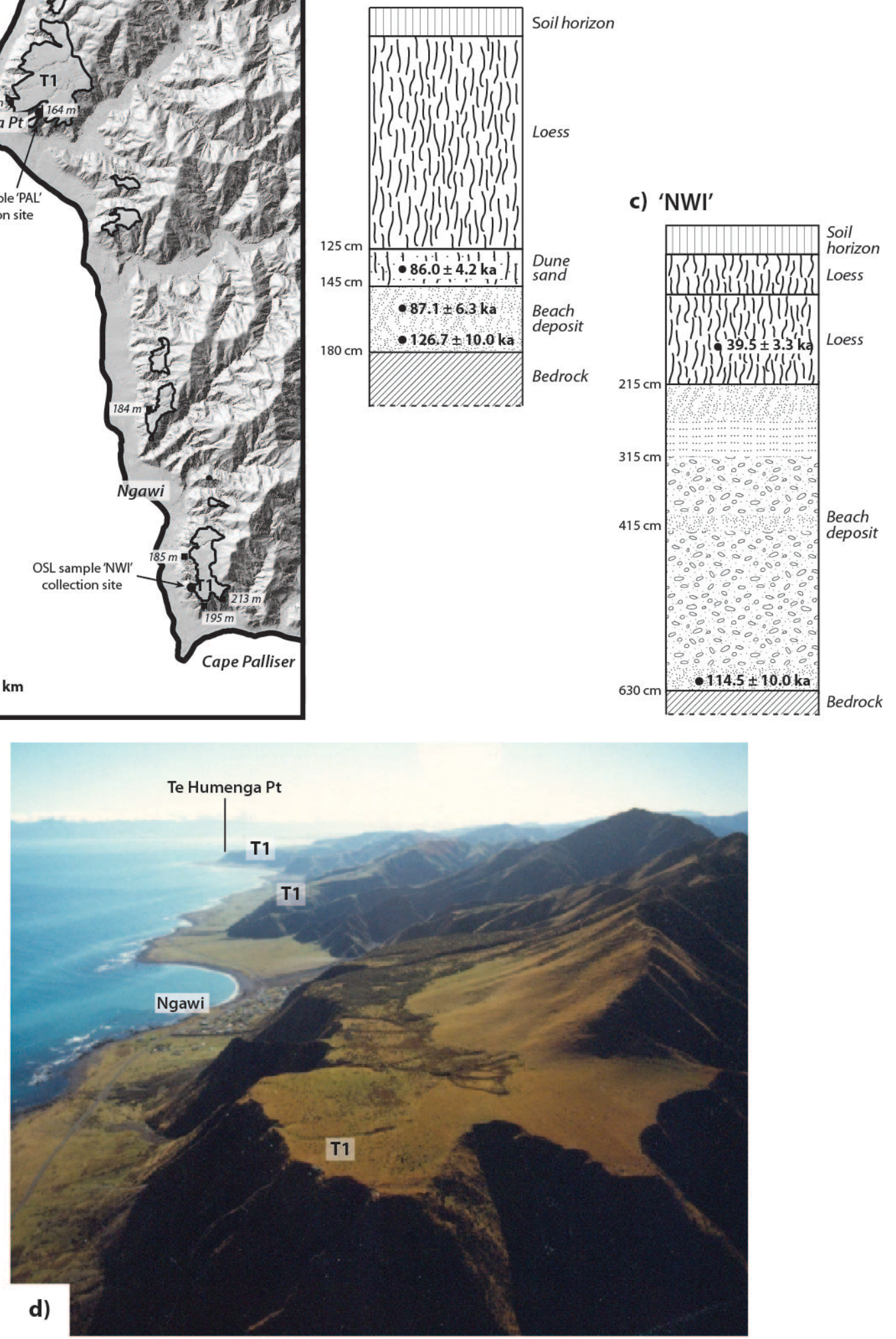

Figure 3.9. Te Humenga - Cape Palliser summary a) terrace maps showing fault locations and OSL sample collection site, on LiDAR backdrop (LiDAR courtesy GWRC); b) stratigraphic section exposed at OSL collection site (samples PAL); c) stratigraphic section exposed at OSL collection site (samples NWI); d) aerial photograph with terraces labelled. Photo taken by L. Homer - GNS Science Visual Media Library VML ID: 20211, Catalogue Number: 11902/2. All terraces labelled in the figure are referred to with the prefix 'TH' (for Te Humenga) in the text. 
oldest loess unit at this same site has been dated as $39.5 \pm 3.3 \mathrm{ka}$ (NWI 2) (see Appx. E Fig. E10).

\subsection{Discussion}

\subsubsection{Terrace Ages}

In this section I use the OSL results together with stratigraphic observations, elevation data and geomorphic mapping to evaluate the age of the terraces preserved along the south coast of the North Island. Because shore platforms develop during sea level highstands, I also compare the OSL ages to recent estimates of timing of said highstands (Fig. 3.10), to suggest the most likely time of formation for the terraces. All MIS age ranges are quoted from Lisiecki and Raymo (2005).

According to our OSL results, the youngest Pleistocene-aged terrace preserved along the south coast is at Baring Head. There, our OSL analysis of beach sands yielded an age of $55.5 \pm 8.7$ ka for the formation of the lowest and youngest terrace, BH-T1. This age overlaps MIS 3 (29$57 \mathrm{ka})$ as well as MIS 4 (57-71 ka). Shore platforms whose radiometrically-determined ages fall within MIS 3 have been reported from other areas of New Zealand: along the Raukumara Peninsula (Wilson et al., 2007), along the Kaikoura and Marlborough coasts (Ota et al., 1996), and in the south Taranaki region (Pillans, 1983). However there are a number of factors which force us to also consider that this terrace may be older than the OSL results suggest.

Firstly, given that the dated sands were collected $\sim 2.5 \mathrm{~m}$ above the BH-T1 shore platform, I consider the OSL results to be a minimum age for the formation of this shore platform. Second, the position of this terrace within the terrace sequence would favour an older age for BH-T1; the OSL age of BH-T3 above it is $161.3 \pm 23.9 \mathrm{ka}$, and only one terrace is preserved between them - BH-T2. MIS 5 shore platforms (from each of $5 \mathrm{a}, 5 \mathrm{c}$ and $5 \mathrm{e}$ ) are the most commonly preserved terraces world-wide, due to this period having some of the highest sea-level elevations prior to today. As such, we would expect to see one or more of these terrace at Baring Head too; especially given that this site favours the preservation of terraces. Thirdly, this sample was close to saturation. It is also possible for OSL dating of feldspar minerals to produce age underestimates due to anomalous fading (Auclair et al., 2003).

The OSL age obtained from the beach coverbeds of BH-T1 at $2 \sigma$ gives an age range of 38.1 $72.9 \mathrm{ka}$. I propose that it is possible that the BH-T1 shore platform may instead have formed during MIS 5a (commencing at $71 \mathrm{ka}$, peak sea level at $82 \mathrm{ka}$ ). The facies change within the thick beach coverbeds of BH-T1, from coarse gravels directly on the shore platform to finer 
sands above, suggests that these deposits were formed during a rise in sea level, which also points towards the beginning of MIS 5a as a possible age of formation for this shore platform.

At Washpool, two samples of beach sands collected within $\sim 40 \mathrm{~cm}$ of the shore platform yielded OSL ages of $63.5 \pm 6.0 \mathrm{ka}$ and $68.8 \pm 8.8 \mathrm{ka}$. These ages are within error of MIS $5 \mathrm{a}$ (71- $\sim 85 \mathrm{ka}$ ). A sample collected $\sim 2.5 \mathrm{~m}$ above the shore platform at the same site yielded an age of $56.1 \pm 2.3 \mathrm{ka}$. Interestingly, this sample is very similar in age and also distance from the shore platform of the sample from Baring Head's BH-T1, providing further evidence that BHT1 could have formed during MIS 5a.

Our OSL results suggest the next oldest terrace is PB-T1, between Lake Ferry and Te Kopi. This terrace was sampled at two sites and yielded ages of $100.7 \pm 12.4$ ka to the west of Whangaimoana beach and $93.0 \pm 4.5 \mathrm{ka}$ from the site to the west. These ages suggest that this terrace formed during MIS 5c (96 ka peak).

Our OSL results suggest that the next oldest terrace is preserved at Tongue Point, as TP-T2. Two OSL ages, within $1 \sigma$ error $(110.0 \pm 10.8 \mathrm{ka}, 125.9 \pm 17.1 \mathrm{ka}$, ) place the formation of this shore platform during MIS 5e (123 ka peak). It follows then that the youngest terrace at Tongue Point, TP-T1, formed more recently, at (or before) MIS 5c.

The main terrace preserved between Te Humenga and Ngawi, TH-T1 yielded ages of $126.7 \pm$ $10.0 \mathrm{ka}$ and $114.5 \pm 10.0 \mathrm{ka}$, suggesting this terrace also formed during MIS 5e.

Although not dated, I conclude that BH-T2 at Baring Head may also have formed during MIS $5 \mathrm{e}$. I base this inference on the relative elevation of this terrace within the Baring Head terrace sequence, on the ages of the bounding terraces, and because shore platforms from MIS 5e are seen to be better preserved globally than MIS $5 \mathrm{c}$.

At Baring Head, the BH-T3 shore platform was dated at $161.3 \pm 23.9 \mathrm{ka}$. This age is within $2 \sigma$ of MIS 7 (191-243 ka), in particular substage MIS 7a, and would imply that the older Baring Head terraces, BH-T4 to BH-T6, may represent even older sea level highstands, possibly earlier substages within MIS 7, or even MIS $9(\sim 317 \mathrm{ka})$, MIS $11(\sim 400 \mathrm{ka})$ and older.

The oldest OSL age obtained was from terrace WH-T1 at Wharekauhau. The ages obtained from the two samples collected at the same site are within $1 \sigma$ error, yielding ages of $206.9 \pm$ $16.6 \mathrm{ka}$ and $198.9 \pm 18.9 \mathrm{ka}$, which correspond with MIS 7, in particular MIS 7a (190 $\pm 2-$ $201 \pm 2 \mathrm{ka}$ ) but also with 7c (206 $\pm 2-217 \pm 2 \mathrm{ka})$ (Dutton et al., 2009). However, the Wharekauhau Fault investigation by Schermer et al. (2009) yielded younger OSL ages for the marine deposits overlying the shore platform; $71 \pm 8 \mathrm{ka}, 106 \pm 24 \mathrm{ka}$ and $127 \pm 20 \mathrm{ka}$, 


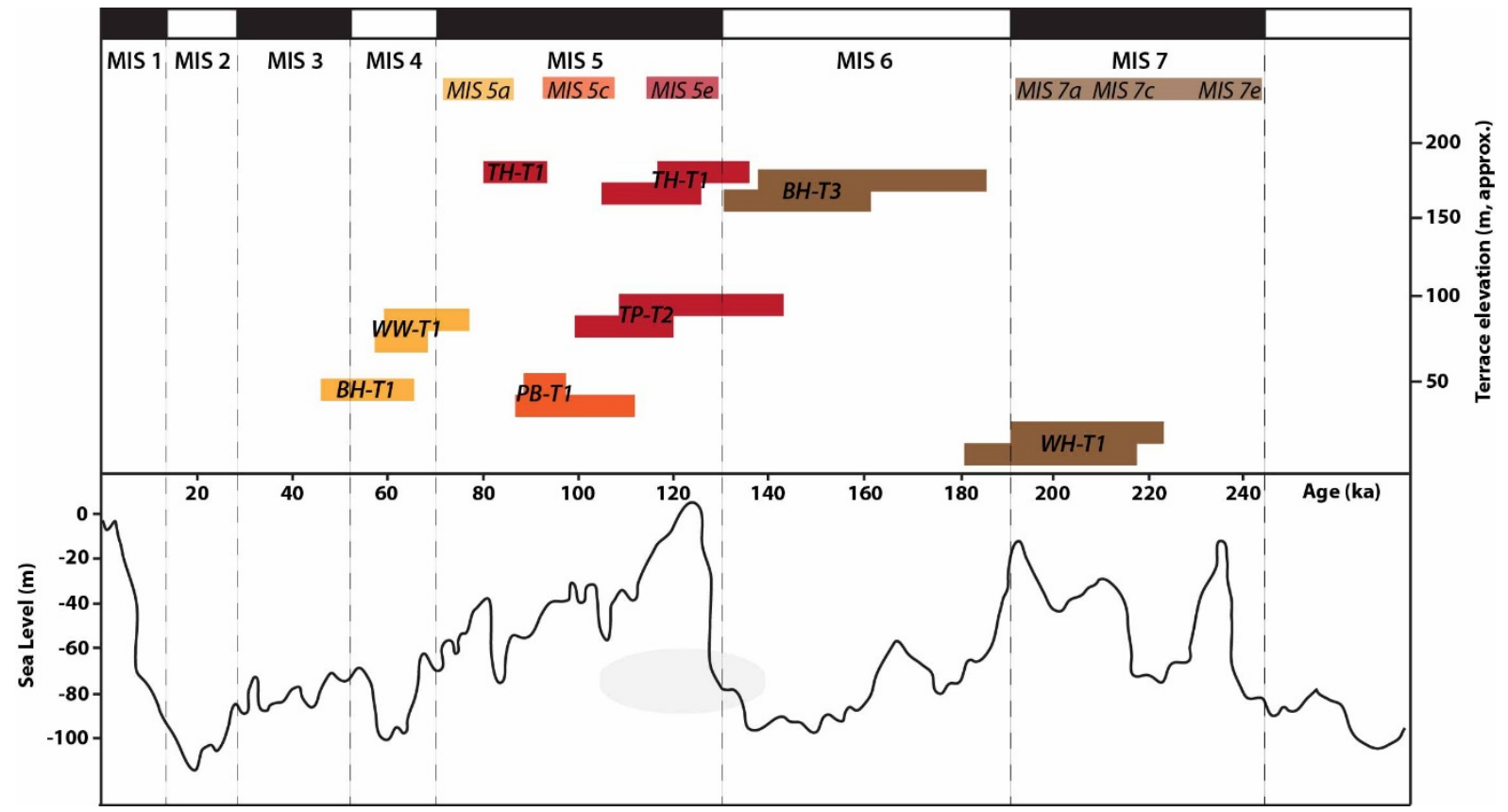

Figure 3.10. OSL ages from the south coast marine terraces. For simplicity, only those ages from closest to the shore platform are shown. Also plotted is sea level (modified after Bintanja et al., 2005; Grant et al., 2014) and MIS stages, with MIS boundaries (Lisiecki \& Raymo, 2005) shown as dashed lines.

corresponding with MIS 5a, 5c and 5e, respectively (see Fig. 3.6). Similarly, OSL ages obtained from mud beds overlying the shore platform by Marra (2003) yielded ages of $117.0 \pm 30.5 \mathrm{ka}$ and $114.8 \pm 33.1 \mathrm{ka}$, corresponding with MIS 5a $-5 \mathrm{e}$. The assemblage of ages from this study and those by Schermer et al. (2009) and Marra (2003) could be explained if the shore platform at Wharekauhau formed during (or before) MIS 7 and remained near sea level, allowing it to be repeatedly occupied during highstands up to and including MIS 5a. Further, our interpretation is also congruous with the current-day elevation of the shore platform at Wharekauhau, which, at only 10 to 15 metres above current-day sea level, remains one of the least-uplifted Pleistocene-aged shore platforms along the south coast of the North Island.

\subsubsection{Terrace Correlation and Comparison with Previously Inferred Terrace Ages}

As mentioned earlier, the majority of previous marine terrace investigations along the south coast of the North Island lacked radiometric dating for the terraces, and terrace ages were estimated based on geomorphic characteristics such as their elevation, degree of preservation and coverbed stratigraphy. Along the Palliser Bay coast, Ghani $(1974 ; 1978)$ estimated that the coastal-most terrace there was cut at either $80 \mathrm{ka}$ (MIS 5a) (at Washpool/ Whatarangi), $84 \mathrm{ka}$ (again MIS 5a) (between Lake Ferry and Te Kopi) or 100 ka (MIS 5c) (between Te Humenga and Cape Palliser). Ota et al. (1981) inferred that the most seaward terrace identified in their 
study between Tongue Point and Baring Head, described as the 'widest, most continuous and most prominent terrace', or as the 'main' terrace, was cut during the 'main event of the last interglacial', MIS 5e. Indeed, due to the fact that sea level during the last interglacial was higher even than that today, MIS 5e terraces are the most commonly preserved terraces worldwide. As such, the common notion was that the majority of the coastal-most terraces along the south coast of the North Island were also cut during MIS 5e. Our data, however, shows evidence for multiple terrace formation events. Here I summarise our terrace ages along the coast (Fig. 3.11) and compare our results with those of previous studies.

The MIS 5a (peak $82 \mathrm{ka}$ ) shore platform is preserved as the main terrace at Baring Head (BHT1) and locally at Washpool/Whatarangi (WW-T1). BH-T1 had previously been inferred as belonging to MIS 5e by Ota et al. (1981), while our age for WW-T1 is in agreeance with the 80 ka age estimated by Ghani $(1974,1978)$ (although, at this same site, he identified a higher terrace and assigned it an age of $84 \mathrm{ka}$ - terraces of different elevations, but whose ages both fall within MIS 5a). Remnants of a MIS 5a terrace may also be preserved at Tongue Point as TP-T1, although, as it has not been dated, this may well be a MIS 5c terrace.

The MIS 5c (peak $96 \mathrm{ka}$ ) terrace is preserved as the main terrace along the Palliser Bay coast, between Lake Ferry and Washpool (PB-T1). This is older than the age estimated by Ghani $(1974,1978)$ of $84 \mathrm{ka}$.

The main terrace at Tongue Point, TP-T2, was cut at MIS 5e (peak $123 \mathrm{ka}$ ), the same age assigned to this terrace by Ota et al. (1981). Our OSL analysis shows the easternmost terraces of the south coast, between Te Humenga Point and Ngawi (TH-T1) are one continuous MIS 5e shore platform. Previously, Ghani $(1974,1978)$ had estimated an age of 100 ka for this terrace.

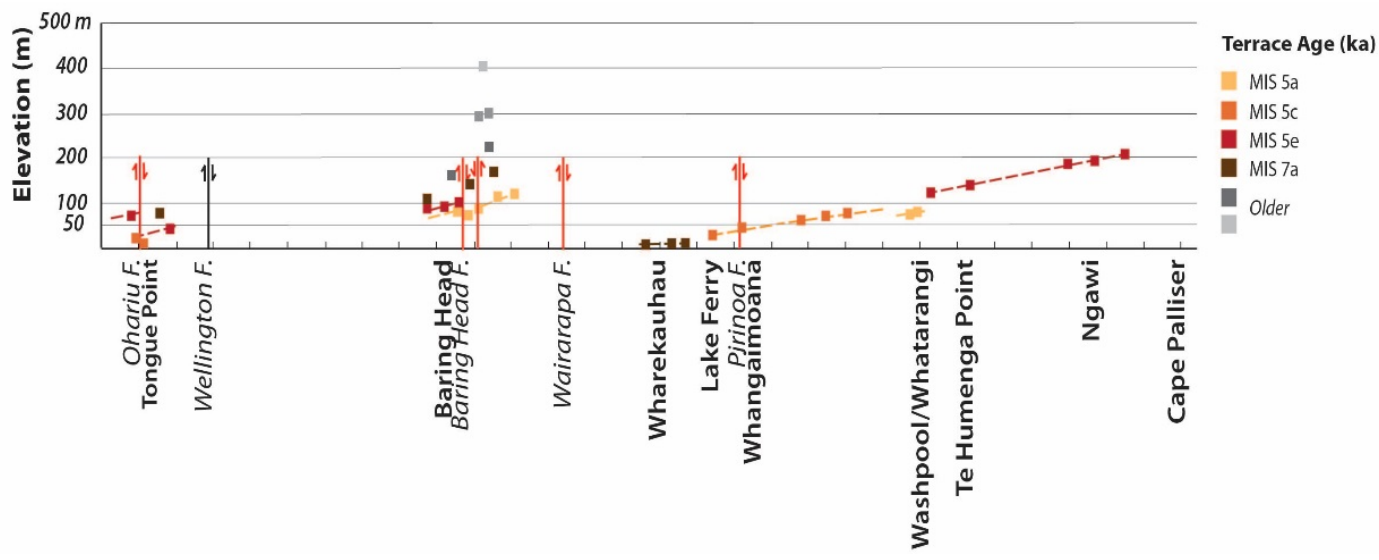

Figure 3.11. Terrace elevations plotted along the coast, showing location of faults that offset the shore platforms. Also shown is the location of the Wellington Fault. 
I deduce the MIS 5e shore platform is also likely preserved behind the main terrace at Washpool (as WW-T2), and is also preserved at Baring Head as BH-T2.

The oldest dated shore platform, cut during MIS 7 (191-243 ka), is that which is preserved as the main terrace at Wharekauhau (WH-T1). Given that both ours and previously published OSL ages (Schermer et al., 2009) from the marine sediments mantling this shore platform span MIS 7 through MIS 5, this shore platform may be even older than that. Our results differ significantly from those of Ghani $(1974,1978)$ who had identified four terraces in the Wharekauhau region, belonging to each of $80 \mathrm{ka}, 84 \mathrm{ka}, 100 \mathrm{ka}$ and $120 \mathrm{ka}$ (from lowest in elevation to highest). However, Ghani based his interpretation on the number of terrace treads he reportedly identified; he did not identify four shore platforms. I identified only one shore platform in this region, and infer that the coverbed deposits have been draped by a series of fan deposits, giving the appearance of a number of terrace treads at different elevations. In addition to being preserved at Wharekauhau, I infer a remnant of the MIS 7a shore platform is also likely preserved as the oldest terrace at Tongue Point (TP-T3), as well as terrace BH-T3 at Baring Head.

\subsubsection{Terrace Preservation and Deformation}

I now discuss the observations regarding terrace preservation and deformation at each of our field sites along the south coast of North Island. I also consider factors such as basement rock type, coastal description, and proximity to upper-plate faults in an attempt to decipher what plays a part in whether, and how well, shore platforms are preserved at any site.

Baring Head is a unique site in that it has the most preserved terraces of any of our south coast field sites - six terraces were identified here. There are a number of factors which may contribute to the high number of preserved terraces at this site alone. Firstly, Baring Head is $\sim 13 \mathrm{~km}$ to the west, and on the upthrown side of, the Wairarapa Fault. Both the direction and degree of tilting of the shore platforms at Baring Head, as well as their elevation, suggest that the site is influenced by movement on the Wairarapa Fault. Consider, for instance, the MIS 7a shore platform at Baring Head, which is at an elevation of $175 \mathrm{~m}$ and is tilted at least $3.0^{\circ}$ to the southwest (based on the degree of tilting of the younger terrace beneath it); the same aged terraces at Wharekauhau, to the immediate east and on the downthrown side of the Wairarapa Fault, has an elevation of only $\sim 10-15 \mathrm{~m}$ and a dip of $0.2^{\circ}$. This indicates a higher uplift rate at Baring Head, which would allow more shore platforms to be cut, and then elevated above marine processes to remain preserved in the landscape. However, this poses the question: why are there no obvious Pleistocene marine terraces preserved at the nearby Turakirae Head 
(situated $\sim 5 \mathrm{~km}$ southeast of Baring Head) which is still on the upthrown side of, and, moreover, closer to, the Wairarapa Fault? The answer may be found in the change in composition of the bedrock between these two sites.

The shore platforms at Baring Head are cut into rocks of the Rakaia Terrane, while the bedrock at Turakirae Head is cut into the Pahau Terrane (see Fig. 3.1). At Turakirae Head, the coastal extent of the Rimutaka Range, slopes are more prone to instability; indeed, slope failure was reported here as a result of the 1855 Wairarapa Fault earthquake (J. Begg, pers. comm., June 2017). It is possible that shore platforms cut into bedrock at Turakirae Head have since been buried by landslides. This difference in rock stability between Baring Head and Turakirae Head, in addition to the higher uplift rates at Turakirae Head (which would elevate developing shore platforms up and away from marine processes) are likely the main reasons why Pleistocene terraces remain well-preserved at one site, but not the other. Although no obvious Pleistocene marine terraces were found at Turakirae Head as part of this investigation, Ota et al. (1981) did report 'small remnants of flat surfaces' in the coastal ranges above Turakirae Head, which were interpreted as the remains of Pleistocene terraces. No shore platform exposures or marine deposits were found to be associated with these surfaces, however, except for one location, where a scattering of beach deposits was reported, at an elevation of $\sim 360 \mathrm{~m}$ (Ota et al., 1981).

Wharekauhau is another noteworthy site, where only one terrace has been preserved. Cut at (or before) MIS 7, this terrace is still close to sea level. The basement rock here is gravels, and it could be argued that this lithology is easily eroded and therefore does not very well preserve a cut shore platform. This factor, in combination with the low uplift rate here, may be the reason why only one terrace remains preserved at this location.

In general, the Pleistocene marine terraces preserved along the south coast of the North Island decrease in elevation towards the west (Fig. 3.11). This is especially obvious along the Palliser Bay coast, where the terraces are more continuous. For example, the MIS 5e terrace, which is continuous between Cape Palliser and Washpool, is $213 \mathrm{~m}$ above sea level at Ngawi, decreasing to an elevation of $141 \mathrm{~m}$ at Te Humenga Point, and $116 \mathrm{~m}$ above Washpool. At Wharekauhau, MIS 5e beach deposits are only 9-15 m above current-day sea level.

In addition to the local vertical offsets of the terraces by upper plate faults, described in detail by site in the Results (Section 3.4), the other characteristic observed in this investigation is that the terrace elevations west of Wharekauhau are influenced by vertical movement on the major upper plate faults, most obviously the Wairarapa and Ohariu faults. Where it is preserved at 
Baring Head, on the upthrown side of the Wairarapa Fault, the MIS 5e shore platform is 101$171 \mathrm{~m}$ in elevation; this same terrace is only $\sim 10-15 \mathrm{~m}$ above sea level west of the Wairarapa Fault, at Wharekauhau. At Tongue Point, the MIS 5e terrace is offset there by the Ohariu Fault, by $\sim 30 \mathrm{~m}$ upthrown to the west. The rates of uplift and mechanisms for this broad-scale terrace deformation will be the focus of the next chapter.

\subsection{Conclusion}

I have mapped the marine terraces preserved along the south coast of the North Island of New Zealand, described their morphology and stratigraphy, and dated them using OSL techniques, resulting in the first radiometrically dates for the majority of these terraces. The youngest and most extensive terraces formed during MIS 5, with evidence of terraces having formed during each of the substages 5a, $5 \mathrm{c}$ and $5 \mathrm{e}$. Based on their relative position within the terrace sequence, terraces from older sea level highstands are also present. Overall, I see evidence for seven different-age Pleistocene terraces along the coast. Although the total number of terraces identified in this investigation is in agreement with previous studies, our more reliable shore platform ages differ from previous estimates in many places along the coast. The terraces are offset by upper plate faults, most obviously the Wairarapa Fault and the Ohariu Fault. In general, the terraces exhibit an overall decrease in elevation towards the west in the Palliser Bar region; near Cape Palliser, the MIS 5e terrace is at an elevation of $\sim 200 \mathrm{~m}$, while at the westernmost Palliser Bay site, the MIS 7a terrace is only $\sim 10-15 \mathrm{~m}$ above current-day sea level. West of Palliser Bay, at Baring Head, on the upthrown side of the Wairarapa fault, the MIS 5e terrace is at an elevation of $\sim 100 \mathrm{~m}$. At Tongue Point, the same terrace is lower in elevation, and is offset locally by the Ohariu Fault, with an elevation of $\sim 70 \mathrm{~m}$ on the western, upthrown side of the fault and $\sim 30 \mathrm{~m}$ on the eastern side. 


\section{References}

Aitken, M. J. and J. Xie (1992). Optical dating using infrared diodes: Young samples, Quaternary Sci. Rev. 11: 147-152.

Auclair, M., Lamothe, M. and Huot, S., 2003. Measurement of anomalous fading for feldspar IRSL using SAR. Radiation measurements, 37(4), pp.487-492.

Bard, E., Hamelin, B. and Fairbanks, R.G., 1990. U-Th ages obtained by mass spectrometry in corals from Barbados: sea level during the past 130, 000 years. Nature, 346(6283), pp.456-458.

Begg, J.G. and Mazengarb, C. (1996). Geology of the Wellington area: sheets R27, R28, and part Q27, scale 1:50,000. Lower Hutt: Institute of Geological \& Nuclear Sciences. Institute of Geological \& Nuclear Sciences geological map 22. 128 p. + 1 fold map.

Begg, J. G. and Johnston, M. R. (2000). Geology of the Wellington Area: Scale 1: 250 000. Institute of Geological \& Nuclear Sciences.

Berryman, K.R., Y. Ota and A.G. Hull (1989): Holocene palaeoseismicity in the fold and thrust belt of the Hikurangi subduction zone, eastern North Island, New Zealand. Tectonophysics, Vol. 163: 185-195.

Berryman, K., 1993. Age, height, and deformation of Holocene marine terraces at Mahia Peninsula, Hikurangi subduction margin, New Zealand. Tectonics, 12(6), pp.1347-1364.

Berryman, K., Y. Ota, T. Miyauchi, A. Hull, K. Clark, K. Ishibashi, N. Iso, N. and N. Litchfield, 2011. Holocene paleoseismic history of upper-plate faults in the southern Hikurangi subduction margin, New Zealand, deduced from marine terrace records. Bulletin of the Seismological Society of America, 101(5), pp.2064-2087.

Bintanja, R., van de Wal, R.S. and Oerlemans, J., 2005. Modelled atmospheric temperatures and global sea levels over the past million years. Nature, 437(7055), pp.125-128.

Bradley, W. C., and G. B. Griggs. "Form, genesis, and deformation of central California wave-cut platforms." Geological Society of America Bulletin 87, no. 3 (1976): 433-449.

Broecker, W.S., Thurber, D.L., Goddard, J., Ku, T.L., Matthews, R.K. and Mesolella, K.J., 1968. Milankovitch hypothesis supported by precise dating of coral reefs and deep-sea sediments. Science, 159(3812), pp.297-300.

Carver, G.A., Jayko, A.S., Valentine, D.W. and Li, W.H., 1994. Coastal uplift associated with the 1992 Cape Mendocino earthquake, northern California. Geology, 22(3), pp.195-198.

Chappell, J., 1974. Geology of coral terraces, Huon Peninsula, New Guinea: a study of Quaternary tectonic movements and sea-level changes. Geological Society of America Bulletin, 85(4), pp.553-570.

Chappell, J., Omura, A., Esat, T., McCulloch, M., Pandolfi, J., Ota, Y. and Pillans, B., 1996. Reconciliaion of late Quaternary sea levels derived from coral terraces at Huon Peninsula with deep sea oxygen isotope records. Earth and Planetary Science Letters, 141(1), pp.227236.

Cotton, C.A. (1912): Notes on Wellington physiography. Transactions of the New Zealand Institute, Vol. 44: 245-265.

Cotton, C. A. (1916). Fault Coasts in New Zealand. Geographical Review, 1(1): 20-47. 
Cotton, C. A. (1918). The outline of New Zealand. Geographical Review, 6(4): 320-340.

Cotton, C. A. (1921). The warped land surface on the south-eastern side of the Port Nicholson Depression, Wellington, New Zealand. Transactions and Proceedings of the New Zealand Institute, Vol. 53: 131-143.

Cotton, C. A. (1942): Shorelines of transverse deformation. Journal of Geomorphology, Vol. 5: 45-58.

Cotton, C. A. (1952). The Wellington Coast: An essay in coastal classification. New Zealand Geographer, 8(1): 48-62.

Cotton, C. A. (1957). Tectonic features in a coastal setting at Wellington. Transactions of the Royal Society of New Zealand, Vol. 84, No. 4: 761-90.

Darby, D. and J. Beavan (2001). Evidence from GPS measurements for contemporary interpolate coupling on the southern Hikurangi subduction thrust and for partitioning of strain in the upper plate, J. Geophys. Res. 106, no. 12: 30881-30891.

DeMets, C., R. G. Gordon, D. F. Argus and S. Stein (1990). Current plate motions, Geophys. J. Int. $101425-478$.

DeMets, C., R. G. Gordon, D. F. Argus and S. Stein (1994). Effect of Recent Revisions to the Geomagnetic Reversal Time Scale on Estimates of Current Plate Motions, Geophys. Res. Lett. 21 2191-2194.

Dutton, A., Bard, E., Antonioli, F., Esat, T.M., Lambeck, K. and McCulloch, M.T., 2009. Phasing and amplitude of sea-level and climate change during the penultimate interglacial. Nature Geoscience, 2(5), pp.355-359.

Fitch, T.J. and Scholz, C.H., 1971. Mechanism of underthrusting in southwest Japan: A model of convergent plate interactions. Journal of Geophysical Research, 76(29), pp.7260-7292.

Ghani, M. A. (1974). Late Cenozoic vertical crustal movements in the southern North Island, New Zealand. Ph.D. thesis. Victoria University of Wellington, Wellington, New Zealand.

Ghani, M. A. (1978). Late Cenozoic vertical crustal movements in the southern North Island, New Zealand. New Zeal. J. Geol. Geophys. Volume 21, Issue 1, 1978.

Grant, K.M., Rohling, E.J., Ramsey, C.B., Cheng, H., Edwards, R.L., Florindo, F., Heslop, D., Marra, F., Roberts, A.P., Tamisiea, M.E. and Williams, F., 2014. Sea-level variability over five glacial cycles. Nature communications, 5 .

Grant-Taylor, T. L. (1963). Geological faults in the Wellington area. NZ Institute of Architects Journal, 30(4), 68-69.

Grant-Taylor, T. L. (1965). Geology of Wellington: A Tour Guide: New Zealand Geological Survey Handbook. New Zealand Department of Scientific and Industrial Research.

Heine, R.W., 1974. Marine terraces at Cape Terawhiti and Tongue Point, Wellington. Journal of the Royal Society of New Zealand, 4(4), pp.485-492.

Henderson, J. (1924). The Post-Tertiary History of New Zealand. In Trans. NZ Inst (Vol. 55, pp. 580599).

Henrys, S., A. Wech, R. Sutherland, T. Stern, M. Savage, H. Sato, K. Mochizuki et al. "SAHKE geophysical transect reveals crustal and subduction zone structure at the southern Hikurangi margin, New Zealand." Geochemistry, Geophysics, Geosystems 14, no. 7 (2013): 2063-2083. 
Okumura, K., 1996. Tephrochronology, correlation, and deformation of marine terraces in eastern Hokkaido, Japan. Geographical Reports of Tokyo Metropolitan University, 31, pp.19-36.

Jara-Munoz, J., Melnick, D., Brill, D. and Strecker, M.R., 2015. Segmentation of the 2010 Maule Chile earthquake rupture from a joint analysis of uplifted marine terraces and seismic-cycle deformation patterns. Quaternary Science Reviews, 113, pp.171-192.

King, L. C. (1930). Raised beaches and other features of the south-east coast of the North Island of New Zealand. Transactions of New Zealand Institute, 61 498-523.

Lang, A. and Wagner, G. A. (1997). Infrared stimulated luminescence dating of Holocene colluvial sediments using the 419nm emission, Quaternary Sci. Rev. 16 393-396.

Lisiecki, L. E., and M. E. Raymo (2005), A Pliocene-Pleistocene stack of 57 globally distributed benthic 18 O records, Paleoceanography, 20, PA1003, doi:10.1029/2004PA001071.

Litchfield, N. \& K. Berryman, 2006: Relations between postglacial fluvial incision rates and uplift rates in the North Island, New Zealand. Journal of Geophysical Research, Vol. 111, F02007, doi: 10.1029/2005JF000374.

Litchfield, N., S. Ellis, K. Berryman, \& A. Nicol, 2007: Insights into subduction-related uplift along the Hikurangi Margin, New Zealand, using numerical modelling. Journal of Geophysical Research, Vol. 112, F02021, doi: 10.1029/2006JF000535.

Little, T. A., R. Van Dissen, E. Schermer, and R. Carne, 2009: Late Holocene surface ruptures on the southern Wairarapa fault, New Zealand: Link between earthquakes and the uplifting of beach ridges on a rocky coast. Lithosphere 1, No. 1: 4-28.

Marra, M.J., 2003. Last interglacial beetle fauna from New Zealand. Quaternary Research, 59(1), pp.122-131.

Matsu'ura, T., Kimura, H., Komatsubara, J., Goto, N., Yanagida, M., Ichikawa, K. and Furusawa, A., 2014. Late Quaternary uplift rate inferred from marine terraces, Shimokita Peninsula, northeastern Japan: A preliminary investigation of the buried shoreline angle. Geomorphology, 209, pp.1-17.

Matsu'ura, T., 2015. Late Quaternary uplift rate inferred from marine terraces, Muroto Peninsula, southwest Japan: Forearc deformation in an oblique subduction zone. Geomorphology, 234, pp.133-150.

Matthews, R.K., 1973. Relative elevation of late Pleistocene high sea level stands: Barbados uplift rates and their implications. Quaternary Research, 3(1), pp.147-153.

McKay, A. (1879). The southern part of the east Wairarapa district. New Zealand Geological Survey report of geological explorations during 1878-1879, 12, 75-86.

McSaveney, M. J., Graham, I. J., Begg, J. G., Beu, A. G., Hull, A. G., Kim, K., \& Zondervan, A. (2006). Late Holocene uplift of beach ridges at Turakirae Head, south Wellington coast, New Zealand. New Zealand Journal of Geology and Geophysics, 49(3), 337-358.

Merritts, D. and Bull, W.B., 1989. Interpreting Quaternary uplift rates at the Mendocino triple junction, northern California, from uplifted marine terraces. Geology, 17(11), pp.1020-1024.

Merritts, D.J., 1996. The Mendocino triple junction: Active faults, episodic coastal emergence, and rapid uplift. Journal of Geophysical Research: Solid Earth, 101(B3), pp.6051-6070. 
Mesolella, K.J., Matthews, R.K., Broecker, W.S. and Thurber, D.L., 1969. The astronomical theory of climatic change: Barbados data. The Journal of Geology, pp.250-274.

Muhs, D. R., Kelsey, H. M., Miller, G. H., Kennedy, G. L., Whelan, J. F., \& McInelly, G. W. (1990). Age estimates and uplift rates for late pleistocene marine terraces' Southern Oregon portion of the Cascadia forearc. J. Geophys. Res. 95, no. B5, 6685-6698.

Murray, M.H., Marshall, G.A., Lisowski, M. and Stein, R.S., 1996. The 1992 M= 7 Cape Mendocino, California, earthquake: Coseismic deformation at the south end of the Cascadia megathrust. Journal of Geophysical Research: Solid Earth, 101(B8), pp.17707-17725.

Murray, A. S. and A. G. Wintle (2000). Luminescence dating of quartz using an improved singlealiquot regenerative-dose protocol. Radiat. Meas. 32, no. 1, 57-73.

Nelson, A.R. and Manley, W.F., 1992. Holocene coseismic and aseismic uplift of Isla Mocha, southcentral Chile. Quaternary International, 15, pp.61-76.

Nicol, A., \& J. Beavan, 2003: Shortening of an overriding plate and its implications for slip on a subduction thrust, central Hikurangi margin, New Zealand. Tectonics, Vol. 22, No. 6, doi10.1029/2003TC001521.

Nicol, A., C. Mazengarb, F. Chanier, G. Rait, C. Uruski, and L. Wallace (2007). Tectonic evolution of the active Hikurangi subduction margin, New Zealand, since the Oligocene, Tectonics, 26, TC4002, doi: 10.1029/2006TC002090.

Ota, Y., D.N. Williams \& K.R. Berryman (1981). Late Quaternary Tectonic Map of New Zealand 1:50,000 Parts Sheets Q27, R27 \& R28. New Zealand Geological Survey, Lower Hutt.

Ota, Y., A.G. Hull, \& K.R. Berryman, (1991): Coseismic uplift of Holocene marine terraces in the Pakarae River area, eastern North Island, New Zealand. Quaternary Research, Vol. 35: 331346.

Ota, Y., Pillans, B., Berryman, K., Beu, A., Fujimori, T., Miyauchi, T. Berger, G., Beu, A. G. \& Climo, F. M. (1996). Pleistocene coastal terraces of Kaikoura Peninsula and the Marlborough coast, South Island, New Zealand. New Zealand journal of geology and geophysics, 39(1), 5173.

Park, J. (1909). Some evidences of glaciation on the shores of Cook Strait and Golden Bay. In Transactions of the New Zealand Institute (Vol. 42, pp. 585-588).

Pedoja, K., Ortlieb, L., Dumont, J. F., Lamothe, M., Ghaleb, B., Auclair, M., \& Labrousse, B. (2006). Quaternary coastal uplift along the Talara Arc (Ecuador, Northern Peru) from new marine terrace data. Marine Geology, 228(1), 73-91.

Pillans, B. (1983). Upper Quaternary marine terrace chronology and deformation, south Taranaki, New Zealand. Geology, 11(5), 292-297.

Pillans, B., 1990. Pleistocene marine terraces in New Zealand: a review. New Zealand journal of geology and geophysics, 33(2), pp.219-231.

Reyners, M. (1998). Plate coupling and the hazard of large subduction thrust earthquakes at the Hikurangi subduction zone, New Zealand, New Zeal. J. Geol. Geophys. 41 343-354.

Saillard, M., Hall, S. R., Audin, L., Farber, D. L., Hérail, G., Martinod, J., Regard, V., Finkel, R.C. \& Bondoux, F. (2009). Non-steady long-term uplift rates and Pleistocene marine terrace development along the Andean margin of Chile (31 S) inferred from 10 Be dating. Earth and Planetary Science Letters, 277(1), 50-63. 
Saillard, M., Hall, S. R., Audin, L., Farber, D. L., Regard, V., \& Hérail, G. (2011). Andean coastal uplift and active tectonics in southern Peru: 10 Be surface exposure dating of differentially uplifted marine terrace sequences (San Juan de Marcona, 15.4 S). Geomorphology, 128(3), 178-190.

Schermer, E. R., Little, T. A., \& Rieser, U. (2009). Quaternary deformation along the Wharekauhau fault system, North Island, New Zealand: Implications for an unstable linkage between active strike-slip and thrust faults. Tectonics, 28(6).

Stephenson, W. J., \& Kirk, R. M. (2000). Development of shore platforms on Kaikoura Peninsula, South Island, New Zealand: II: The role of subaerial weathering. Geomorphology, 32(1), 4356.

Stirling, M., McVerry, G., Gerstenberger, M., Litchfield, N., Van Dissen, R., Berryman, K., Barnes, P., Wallace, L., Villamor, P., Langridge, R. and Lamarche, G., 2012. National seismic hazard model for New Zealand: 2010 update. Bulletin of the Seismological Society of America, 102(4), pp.1514-1542.

Trenhaile, A. S. (1987). The geomorphology of rock coasts. Oxford University Press, USA.

Trenhaile, A. S. (2008). Modeling the role of weathering in shore platform development. Geomorphology 94 24-39.

Van Dissen, R. and K. R. Berryman (1996). Surface rupture earthquakes over the last $\sim 1000$ years in the Wellington region, New Zealand, and implications for ground shaking hazard, J. Geophys. Res. 101, B3, 5999-6019.

Wallace, L. M., J. Beavan, R. McCaffrey and D. Darby (2004). Subduction zone coupling and tectonic block rotations in the North Island, New Zealand, J. Geophys. Res. 109, B12406, doi: 10.1029/2004JB003241.

Wallace, L. M., J. Beavan, R. McCaffrey, K. Berryman, \& P. Denys (2007). Balancing the plate motion budget in the South Island, New Zealand using GPS, geological and seismological data. Geophysical Journal International, 168(1), 332-352.

Wallace, L. M., M. Reyners, U. Cochran, S. Bannister, P.M. Barnes, K. Berryman, Downes, G., Eberhart-Phillips, D., Fagereng, A., Ellis, S. and Nicol, A., (2009). Characterizing the seismogenic zone of a major plate boundary subduction thrust: Hikurangi Margin, New Zealand. Geochemistry, Geophysics, Geosystems, 10(10).

Williams, C.A., Eberhart-Phillips, D., Bannister, S., Barker, D.H., Henrys, S., Reyners, M. and Sutherland, R., 2013. Revised interface geometry for the Hikurangi subduction zone, New Zealand. Seismological Research Letters, 84(6), pp.1066-1073.

Wilson, K.J., N.J. Litchfield, K.R. Berryman \& T.A. Little, 2007: Distribution, age, and uplift patterns of Pleistocene marine terraces of the northern Raukumara Peninsula, North Island, New Zealand. New Zealand Journal of Geology and Geophysics, 50: 181-191.

Zazo, C., Goy, J. L., Dabrio, C. J., Bardají, T., Hillaire-Marcel, C., Ghaleb, B, Gonzalez-Delgado, J-A. \& Soler, V. (2003). Pleistocene raised marine terraces of the Spanish Mediterranean and Atlantic coasts: records of coastal uplift, sea-level highstands and climate changes. Marine Geology, 194(1), 103-133. 


\title{
CHAPTER FOUR
}

\author{
SOUTHERN HIKURANGI MARGIN \\ UPLIFT RATES AND TECTONIC IMPLICATIONS \\ BASED ON NEW MARINE TERRACE DATA \\ FROM THE SOUTH COAST OF THE NORTH ISLAND, NEW ZEALAND
}

\begin{abstract}
Pleistocene tectonic uplift of the southern Hikurangi margin is recorded by ancient emergent shorelines preserved along the south coast of the North Island of New Zealand. Optically Stimulated Luminescence (OSL) analysis of overlying marine deposits show that these shore platforms were created during Marine Isotope Stages (MIS) 5a, 5c, 5e and 7a. The age of these terraces, and their corresponding strandline elevations, are used to calculate uplift rates across the margin. The highest uplift rate, $1.7 \pm 0.1 \mathrm{~mm} / \mathrm{yr}$, and maximum tilting, $2.9^{\circ}$ to the west, are observed on the easternmost terrace, near Cape Palliser, $\sim 40 \mathrm{~km}$ from the Hikurangi Trough. Uplift decreases steadily along the Palliser Bay coast, to $0.2 \pm 0.1 \mathrm{~mm} / \mathrm{yr}$ at Wharekauhau, $\sim 70 \mathrm{~km}$ from the trough. Vertical offsets, as observed on the marine terraces, are seen across the major active upper plate faults, most notably on the Wairarapa and Ohariu faults. Uplift rates at Baring Head, on the upthrown side of the Wairarapa Fault, are $\sim 0.7-1.6 \mathrm{~mm} / \mathrm{yr}$. At Tongue Point, where the Ohariu Fault offsets the marine terraces preserved there, uplift calculated from the western, upthrown side of the fault is $0.6 \pm 0.1 \mathrm{~mm} / \mathrm{yr}$, while uplift calculated from the downthrown side is $0.2 \pm 0.1 \mathrm{~mm} / \mathrm{yr}$. The $\sim 30 \mathrm{~km}$-long pattern of uplift and tilting evident on the Palliser Bay coast, in the forearc region within $\sim 40-70 \mathrm{~km}$ of the trough, indicates that deep-seated subduction processes, most likely subduction of the buoyant Hikurangi Plateau and permanent coseismic uplift resulting from repeated megathrust earthquakes, are responsible for the permanent vertical deformation observed there. West of Palliser Bay, at a distance of $>70 \mathrm{~km}$ from the Hikurangi Trough, the abrupt increases in uplift rate across the Wairarapa and Ohariu Faults, suggest that at this distance, in the Axial Ranges, movement on the major active upper plate faults contributes to tectonic uplift in addition to the sediment underplating identified beneath this region in recent seismic reflection imaging.
\end{abstract}




\subsection{Introduction}

Marine terraces preserved along coastal regions at active plate margins provide valuable information for investigating vertical tectonic deformation, in particular uplift. By combining shore platform elevation data, in particular that of the ancient shoreline (or strandline), with the age of that terrace, uplift rate estimates since the time of terrace abandonment can be made (e.g. Bradley \& Griggs, 1976; Ghani, 1978; Ota et al., 1981; Muhs et al., 1990; 1992; Machare \& Ortlieb, 1992; Ortlieb et al., 1996; Zazo et al., 2003). Furthermore, because deformation of the overriding plate reflects underlying subduction processes, observed patterns of deformation can be evaluated to suggest which processes may be responsible for them (e.g. Merritts \& Bull, 1989; Berryman, 1993 a, b; Ota et al., 1996; Pedoja et al., 2006; Wilson et al., 2007 a, b; Saillard et al., 2009, 2011; Marquardt et al., 2004; Matsu'ura et al., 2009; 2014; Matsu'ura, 2015).

Across the southern North Island of New Zealand, spanning $\sim 100 \mathrm{~km}$ of coastline, in a region 40-100 km from the Hikurangi Trough, a series of Pleistocene marine terraces are today elevated to heights of up to $\sim 400 \mathrm{~m}$ above current day sea level, (e.g. Ghani, 1974; 1978; Ota et al., 1981; Begg \& Johnston, 2000, Chapter 3). In Chapter 3, I presented a new interpretation of the distribution of these terraces, preserved on the south coast between Cape Terawhiti and Cape Palliser, and the stratigraphy of their cover beds. I also reported shore platform elevations for these terraces as collected using Real-Time Kinematic (RTK) Global Navigational Satellite Systems (GNSS). Finally, I presented Optically Stimulated Luminescence (OSL) ages for the terraces - the first radiometrically-determined ages for the majority of these Pleistocene terraces. Using these data, I correlated the terraces by age along the coast. A total of seven marine terraces were identified, the youngest four of which correspond to Marine Isotope Stages (MIS) 5a (peak age $82 \mathrm{ka}), 5 \mathrm{c}(96 \mathrm{ka}), 5 \mathrm{e}(123 \mathrm{ka})$ and MIS 7a (196 ka) (ages from Lisiecki \& Raymo, 2005) (Fig. 4.1).

My objective in this chapter is to quantify Quaternary tectonic uplift across the southern Hikurangi margin. I use my new shore platform elevation data and calculated attitudes to reconstruct strandline elevations for these terraces. I then correct these elevations for sea level at the time of their formation, using my new shore platform chronologic results and the latest available findings on historic sea level elevations. Consequently, the resulting uplift estimates are the most robust uplift calculations for the southern Hikurangi margin available to date. Finally, I consider the association between the distribution of coastal uplift across the southern North Island, and subduction processes of the southern Hikurangi margin. 


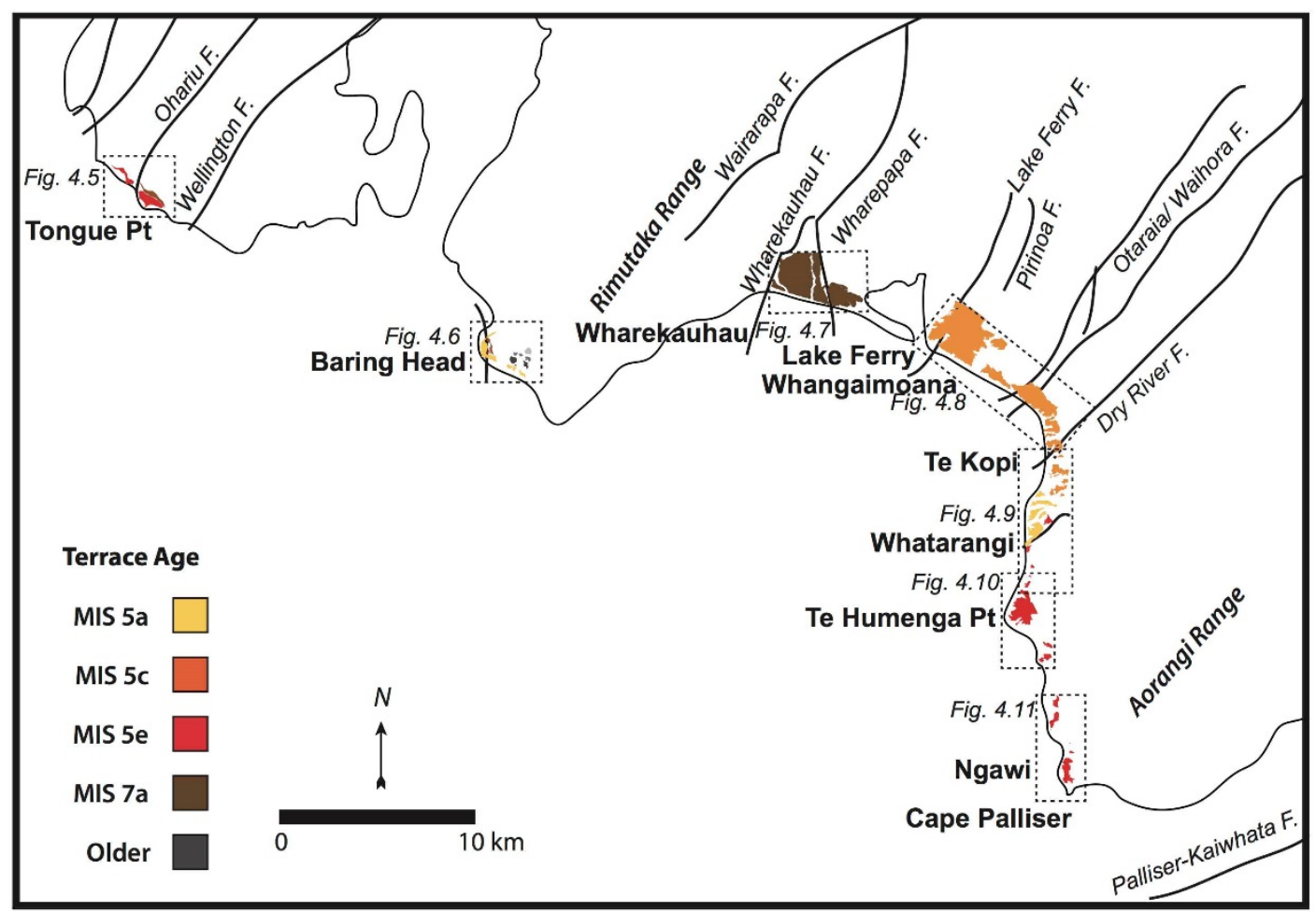

Figure 4.1. Southern North Island of New Zealand, showing distribution of preserved marine terraces along the south coast. Marine Isotope Stages (MIS) ages are: 5a (peak age $82 \mathrm{ka}), 5 \mathrm{c}(96 \mathrm{ka}), 5 \mathrm{e}(123 \mathrm{ka})$ and MIS $7 \mathrm{a}(196 \mathrm{ka})$ from Lisiecki \& Raymo (2005).

\subsection{Background}

\subsubsection{Vertical Deformation Processes at Active Margins}

A number of processes, both seismic and aseismic, contribute to vertical deformation at active margins. Perhaps one of the most familiar occurrences at active margins is that of megathrust earthquakes. Vertical deformation due to megathrust earthquakes, such as the $2011 \mathrm{M}_{\mathrm{w}} 9.1$ Tohoku-Oki earthquake, the $2004 \mathrm{M}_{\mathrm{w}} 9.3$ Sumatra-Andaman earthquake, the $1964 \mathrm{M}_{\mathrm{w}} 9.4$ in Alaska, and the $1960 \mathrm{M}_{\mathrm{w}} 9.5$ Chile earthquake, generally results in coseismic uplift of the coast closest to the subduction trench (up to a distance of $\sim 150 \mathrm{~km}$ from the trench), and a similarlyoriented region of subsidence further from the trench (between $\sim 150-250 \mathrm{~km}$ ) (e.g. Grantz et al., 1964; Plafker, 1965; 1972; Subarya et al., 2006; Briggs et al., 2006; Vigny et al., 2011). This coseismic vertical deformation can be expressed along the margin over distances approaching $1000 \mathrm{~km}$ or greater; the precise distances being controlled by the geometry of the underlying subduction interface and the area of fault rupture and slip.

Strain released during earthquake ruptures of upper plate faults at active margins can also result in coastal uplift. Local examples include coseismic deformation resulting from the $\mathrm{M}_{\mathrm{w}} 7.8$ 
Hawke's Bay earthquake of 1931, which reportedly uplifted the coast around Napier by up to $\sim 2.7 \mathrm{~m}$ over an area $\sim 120 \mathrm{~km}$ long and $\sim 20 \mathrm{~km}$ wide (Hull, 1990). The $1855 \mathrm{M}_{\mathrm{w}} 8.2$ Wairarapa Fault earthquake uplifted the coast around Turakirae Head, $\sim 10 \mathrm{~km}$ from the fault, by up to $\sim 6.4 \mathrm{~m}$ (McSaveney et al., 2006), while Wellington Harbour experienced about $1.4 \mathrm{~m}$ of uplift (Downes, 2005; Begg \& McSaveney, 2005). Reports of coseismic uplift were received from as far as Makara Beach, $\sim 30 \mathrm{~km}$ from the Wairarapa Fault (Beavan \& Darby, 2005). During the $2016 \mathrm{M}_{\mathrm{w}} 7.8$ Kaikoura earthquake, an area of $\sim 110 \mathrm{~km}$ of the local coastline was uplifted by up to $6.5 \mathrm{~m}$ (Hamling et al., 2017; Clark et al., 2017).

Vertical deformation can also be the result of subtle, ongoing tectonic movement. For instance, following a megathrust earthquake, post-seismic relaxation followed by longer-term interseismic elastic strain accumulation generally results in vertical motion in the opposite directions as coseismic deformation from a subduction interface earthquake (subsidence in the zone of co-seismic uplift and vice versa). In some instances, such as after the $1950 \mathrm{M}_{\mathrm{w}} 7.7$ Nicoya Peninsula, Costa Rica earthquake, post-seismic relaxation completely removed the uplift which accompanied the earthquake; locals reported the shoreline dropping in elevation at the time of the earthquake, only to return to its former elevation forty years later (Marshall $\&$ Anderson, 1995). The vertical deformation that accompanied this megathrust event was elastic and recoverable. Continuous GPS observations over the last few decades from the lower North Island of New Zealand show that interseismic strain in this region is currently causing the area to subside up to $\sim 4 \mathrm{~mm} / \mathrm{yr}$, with subsidence rates generally increasing towards the Hikurangi Trough (Beavan \& Litchfield, 2012); this subsidence is presumed to be the result of interseismic coupling and is therefore expected to be relieved by a subduction earthquake.

In comparison, when coseismic uplift is not completely removed by post seismic relaxation and interseismic strain accumulation, then megathrust earthquakes can leave a permanent signal of vertical deformation in the landscape. In these instances, over many megathrust earthquake cycles (1000's yrs) evidence of multiple megathrust earthquakes could be preserved as a stepped pattern in the coastal topography, with each step being a former shore platform uplifted coseismically. Each of the Holocene terraces preserved at Cape Mendocino, California, are thought to be a result of rupture on the Cascadia megathrust (e.g. Merritts \& Bull, 1989; Carver et al., 1994; Murray et al., 1996; Merritts, 1996), as are some of the emergent strandlines along the coast of south-central Chile (e.g. Nelson \& Manley, 1992). Multiple rupture events on an upper plate fault could also be expressed as a stepped pattern in the coastal topography. For example, repeated rupture on the Wairarapa Fault has resulted in coseismic uplift of the northwest side of the fault, as evident in a stepped series of four elevated beach ridges $(\sim 24 \mathrm{~m}$ 
cumulative since $\sim 6.7 \mathrm{ka}$ ) at Turakirae Head (McSaveney et al., 2006). Coseismic deformation due to rupture on upper plate fault structures can be differentiated from megathrust coseismic uplift, because upper plate faults tend to be more steeply dipping and cover a smaller area, therefore the deformation is more localised and of a smaller wavelength (10's of km from the fault) than that resulting from megathrust events ( 100-150 km from the trench) (Fig. 4.2).

Over even longer periods of time, net vertical deformation at active margins may not only reflect coseismic deformation (if at all), but can be the result of a number of processes combined. Characteristics of the subducting plate, such as crustal thickness and variations in topography, can also influence rates and patterns of deformation of the upper plate. These deepseated processes result in gradual changes detectable over 100,000's years. For instance, along the coast of southern Peru, uplift rates due to post seismic and interseismic strain accumulation have increased since $\sim 800$ ka due to the Nazca Ridge subduction (Saillard et al., 2011). Finite element modelling by Lichfield et al. (2007), constrained by uplift rates calculated from marine terraces and incision rates measured from fluvial terraces, suggests that uplift across the northern and central Hikurangi margin reflects a combination of sediment underplating (the accumulation of sediments between the subducting plate and the upper plate), and seamount subduction beneath that region.

As a result, interpreting coseismic uplift from Pleistocene marine terraces can be more complicated than their Holocene counterparts. For one, the original surface of Pleistocene terraces, which may indeed show evidence of coseismic uplift events such as preserved beach ridges, are now obscured by younger terrestrial coverbeds. In addition, a sequence of preserved Pleistocene terraces spans several highstands, between which sea level has varied, sometimes by many tens of meters. As a result, the elevation of Pleistocene marine terraces above currentday mean sea level does not necessarily approximate the true value of permanent tectonic uplift - the true value may be more or less, depending on whether sea level was lower or higher, respectively, at the time of their formation. Vertical deformation due to other deep-seated processes, such as instance interseismic strain accumulation, or sediment underplating, could also overprint on the current-day elevations of terraces along the coast. Nonetheless, we can still evaluate the wavelength of the deformation to determine whether the uplift has most likely been due to deep-seated subduction processes or upper plate structures, remembering that, in general, broad-wavelength (100's of km) signatures more typically result from deep-seated processes, including possible megathrust earthquakes, while shorter wavelength (10's of $\mathrm{km})$ is more likely the result of upper plate structures. 

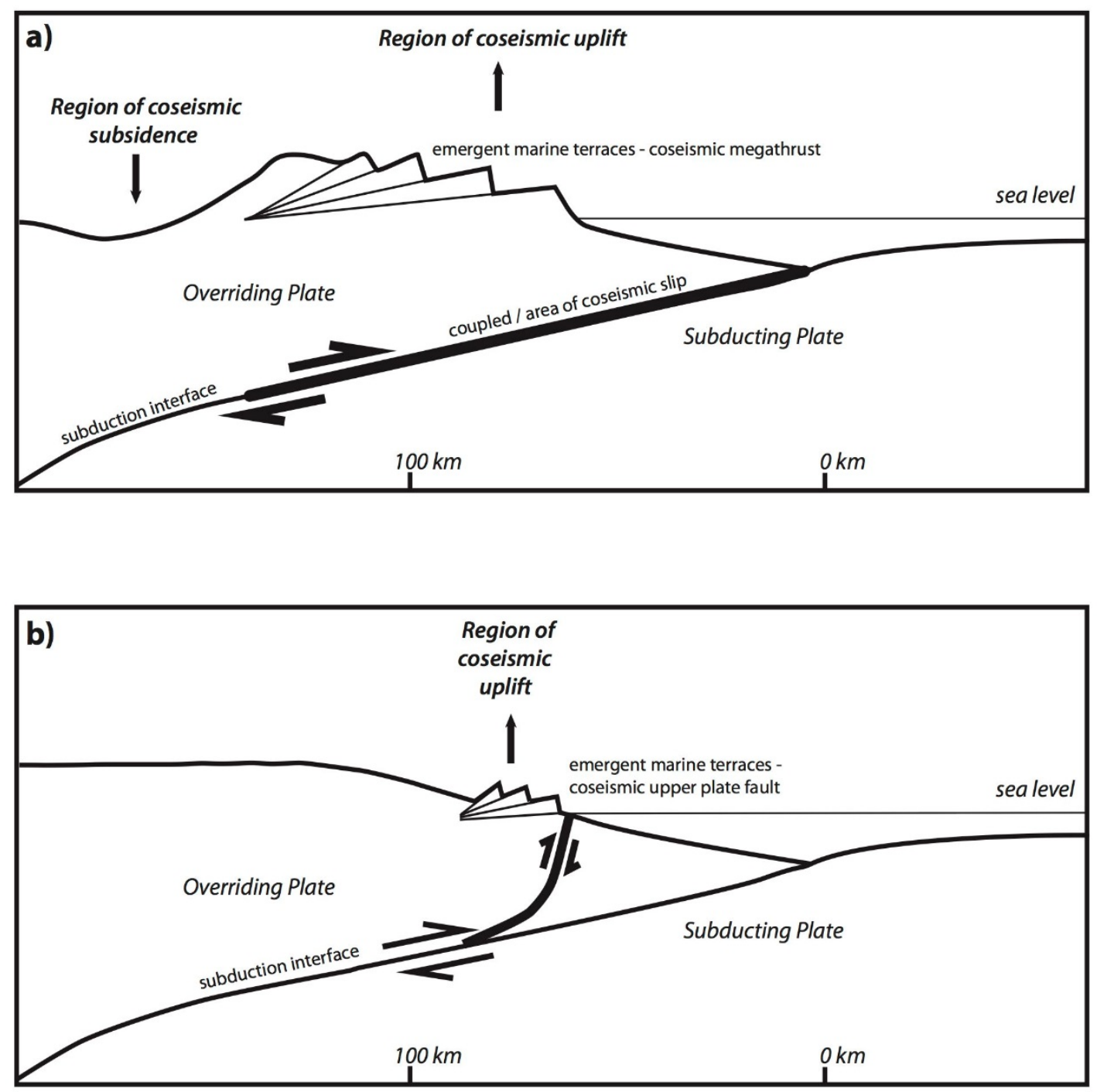

Figure 4.2. Schematic cross-section showing likely marine terrace uplift patterns, resulting from different coseismic uplift processes at subduction margins; a) repeated megathrust earthquakes; b) repeated upper plate fault ruptures.

\subsubsection{Previous Work}

Results from previous investigations of the Pleistocene marine terraces along the south coast of the North Island by Ghani $(1974 ; 1978)$ and Ota et al. (1981), outlined in the Background section of Chapter 3, also included uplift rate estimates. The uplift rates Ghani (1978) calculated, using terrace tread elevations, range from 2.0-1.5 mm/yr at Cape Palliser, decreasing to $0.5 \mathrm{~mm} / \mathrm{yr}$ at Lake Ferry, and slightly increasing again to $1.0 \mathrm{~mm} / \mathrm{yr}$ at the westernmost site of his study, at Wharekauhau. In order to take eustatic sea level into account, Ghani $(1974$; 1978) had calculated his own estimates by assuming that sea level during MIS 5e at $125 \mathrm{ka}$ was exactly equal to that of the current day, and that there was a constant uplift rate since then. Ota et al. (1981) had assumed that all of the 'main' terraces preserved along the 
south coast were created during the 'main high sea level event of the last interglacial', then estimated to have an age of about $120 \mathrm{ka}$. Using terrace surface elevations, their uplift rate estimates ranged from $\sim 0.6 \mathrm{~mm} / \mathrm{yr}$ at Tongue Point (slightly higher on the uplifted side on the Ohariu Fault) to $0.9-1.0 \mathrm{~mm} / \mathrm{yr}$ at Baring Head (increasing to the east, towards the Wairarapa Fault). In their uplift rate calculations, Ota et al. (1981) had estimated that sea level during this time was the same as that of the current day, based on work by Chappell (1974). Since these studies however, there have been significant advances in estimates of eustatic sea level; this will be described in more detail in the following section, 4.2.3.

Studies of vertical deformation across the southern Hikurangi margin, as they relate to subduction processes, have revealed site-specific evidence of subduction earthquakes (e.g. Cochran et al., 2007; Clark et al., 2011; Clark et al., 2015). Clark et al. (2015) found evidence of earthquake-related subsidence at Big Lagoon ('BL' in Fig. 4.3) at the northernmost South Island. Employing an elastic dislocation half-space model, which was constrained by their findings and paleoearthquake chronologies of upper plate faults, they estimated the areas likely to experience coseismic uplift during a megathrust earthquake in this region, and those likely to experience subsidence. According to their model, which assumes a megathrust recurrence interval of $500 \mathrm{yrs}$, maximum coseismic uplift due to a megathrust earthquake, as observed onland, would be in the order of $\sim 1.0-1.5 \mathrm{~m}$ along the east coast of the North Island, nearest to the Hikurangi Trough. In terms of the sites investigated in this marine terrace study, Clark et al. (2015) estimated $\sim 1 \mathrm{~m}$ of uplift between Cape Palliser and Te Kopi, decreasing to the west to $<0.5 \mathrm{~m}$ at Wharekauhau, and zero uplift at Turakirae Head; sites further to the west have been estimated to experience subsidence (see Fig. 4.3).

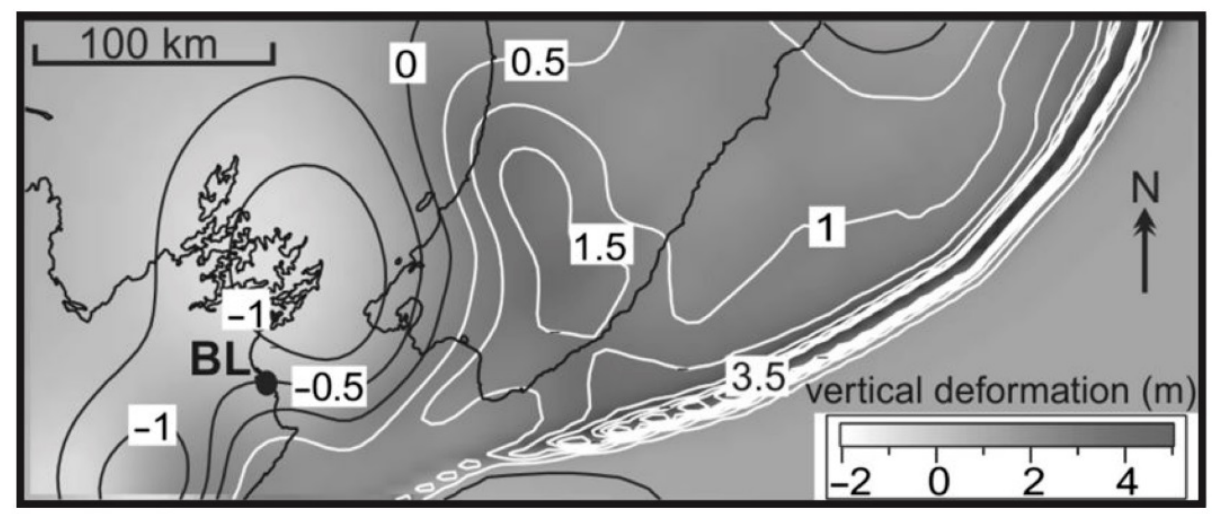

Figure 4.3. Upper plate coseismic vertical deformation (uplift shown as white contours, subsidence shown in black) resulting from a megathrust earthquake releasing $500 \mathrm{yrs}$ of accumulated slip on the plate interface at the southern Hikurangi margin, as estimated by an elastic dislocation half-space model (from Clark et al., 2015). 'BL' denotes Big Lagoon field site. 
In Chapter 3, I presented evidence that the shore platforms along the south coast of the North Island were created during highstands corresponding to MIS 5a, 5c, 5e and 7a. Because sea level has fluctuated throughout geological time, in order to quantify true tectonic uplift for a shore platform, one needs to know the sea level elevation for the particular highstand during which it formed.

Eustatic sea level reconstructions can be produced in a number of ways. Direct estimates are commonly based on radiometric dating and elevation measurements of paleo sea-level indicators - landforms or sediments whose position relative to sea level at the time of their formation is known, such as erosional shore platforms or fossil coral platforms. For former highstands where sea level was higher than the present-day, namely during MIS 5e, this method is most effective in a tectonically stable region, without the need to consider the complexity of uplift. One such region is Western Australia, where there have been a number of studies of the MIS 5e marine terraces preserved there (e.g. Stirling et al., 1998; O’Leary et al., 2008). During other highstands, for example MIS 5a, MIS 5c and MIS 7a, sea level was lower than the currentday, hence areas that experience tectonic uplift are required so that shore platforms corresponding to these highstands have been uplifted above coastal erosion processes during subsequent highstands, to remain preserved in the landscape. In this scenario, in order to determine sea level, the amount of tectonic uplift since the terrace was abandoned needs to be known so that the current elevation can be corrected for that uplift. Examples of such tectonically active areas, and from which sea level has been estimated from preserved coastal terrace sequences, include along the Huon Peninsula in Papua New Guinea (e.g. Chappell et al., 1996; Chappell, 2002), in Barbados (e.g. Potter et al., 2004; Thompson \& Goldstein, 2005) and the Bahamas (e.g. Thompson et al., 2011).

Other sea level reconstruction methods are based on proxy data. One of the more common of these is a measure of the ratio of the stable isotopes oxygen-18 $\left({ }^{18} \mathrm{O}\right)$ and oxygen-16 $\left({ }^{16} \mathrm{O}\right)$ found in fossil calcite contained within benthic and planktonic foraminifera within marine sediments. The oxygen isotope ratio is a function of the total global ice volume and deep ocean temperature, from which information on sea level can be extracted. In certain favourable locations, such as the Red Sea, oxygen isotope ratios are particularly sensitive to sea level change. This is due to the narrow and shallow strait connecting the Red Sea to the open ocean, which results in increased evaporation (and thereby salinity) with sea-level lowering events, which in turn amplifies stable oxygen isotope signals (Rohling et al., 2008; Grant et al., 2012; 2014). The Red Sea data is significant because it is one of the rare sites that provides a 
continuous record of sea level for the last $500 \mathrm{ka}$ (Grant et al., 2014). However, because oxygen isotope ratios are also influenced by deep ocean temperature, estimates of sea level from different ocean basins can contain a large uncertainty, which complicates this proxy.

A potential limitation of any sea level reconstruction study is that, often, an investigation uses only one method. In addition, site-specific studies can be problematic because regional sea level can depart significantly from the global mean. This is particularly true for sites that are proximal to the location of former ice sheets, because local sea level at such sites is strongly influenced by glacio-hydro-isostatic effects - the isostatic adjustment of the earth's surface to changes in ice and water loads, and the related gravitational effects (e.g. Lambeck \& Nakada, 1992). As a result, different methods and studies from different sites often result in varying paleo sea level estimates (Fig 4.4).

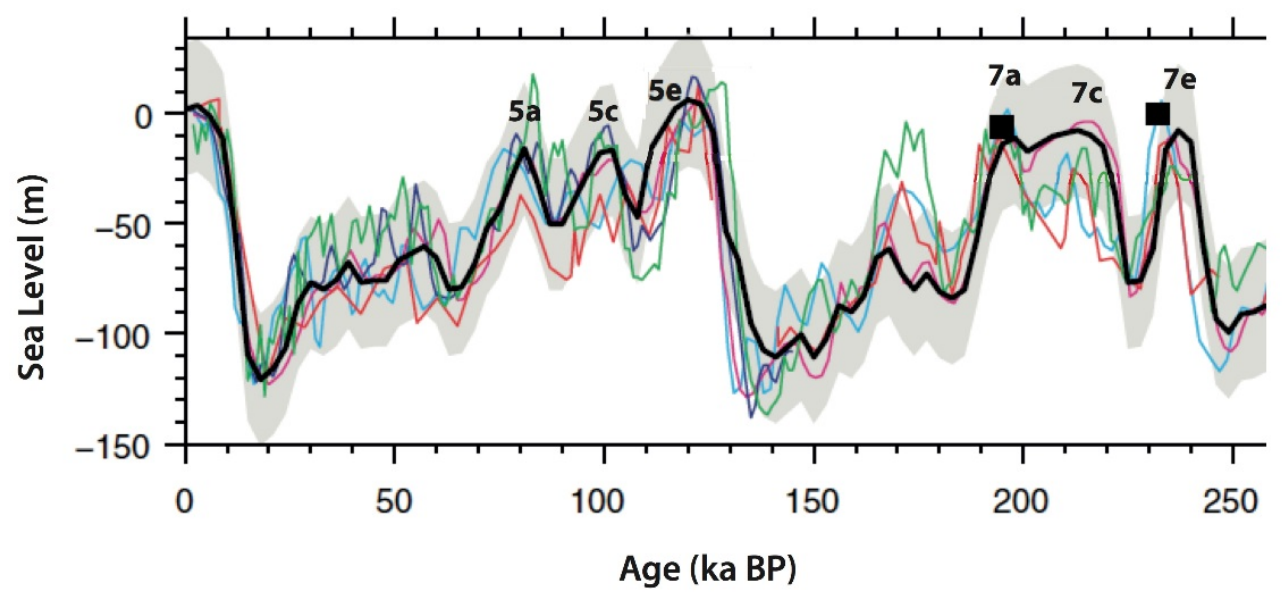

Figure 4.4. A comparison of sea level estimate of different studies (after Siddall et al., 2007). Cyan - Lea et al. (2002); Red - Siddall et al. (2003); Green - Shackleton (2000); Magenta - Waelbroeck et al. (2002); Indigo - Labeyrie et al. (1987); Black squares - Murray-Wallace (2002); Black line and surrounding grey region - Scaled benthic isotopes after Cutler et al. (2003).

Due to the issues with site-specific sea level reconstructions outlined above, ideally, this investigation of uplift along the southern Hikurangi margin would incorporate sea level estimates calculated from New Zealand. Although eustatic sea level reconstructions are available for New Zealand for the Holocene (e.g. Gibb, 1986; Clement et al., 2016), reliable eustatic sea level estimates calculated from New Zealand for the MIS highstands relevant to this investigation, namely MIS 5a, 5c, 5e and 7a, are not available. Previous studies of tectonic uplift in New Zealand, as determined from emergent Pleistocene marine terraces (e.g. Berryman, 1993 (b); Ota et al., 1996; Wilson et al., 2007 (a)) have incorporated sea level estimates by Chappell \& Shackleton (1986), determined from uplifted terraces at the Huon 
Peninsula in Papua New Guinea, or estimates of Pillans et al. (1998) based on Huon Peninsula data and oxygen isotope data. However, rather than looking to sea level estimates from one specific site, a potentially more robust approach is to employ eustatic sea level estimates determined from 'pooling' of high-quality data. Such data, from a number of sites for a specific time in the past, which has been corrected for isostatic contributions and probabilistically analysed, has been the approach of a number of the latest sea level reconstruction attempts, as summarised below.

The most recent investigations of sea level that encompass the penultimate interglacial, MIS 7, include that by Bard et al. (2002), who measured the depth of, and radiometrically dated the calcite within, drowned speleothems in Italy. They compared their results to the depth and age of speleothems in the Bahamas (Li et al., 1989) to constrain that sea level during MIS 7a peaked at between $-18 \mathrm{~m}$ and $-9 \mathrm{~m}$ (relative to present sea level). This data was included in a review of all previously published data by Siddall et al. (2007) (see Fig. 4.4) who constrained sea level for MIS 7a to between -5 and -15 m, while Grant et al. (2012; 2014), using radiometric dating of speleothem and marine sediment stable oxygen isotope records from the Red Sea and the eastern Mediterranean, estimate a peak sea level of $-11.8 \pm 3.2 \mathrm{~m}(2 \sigma)$.

The last interglacial, MIS 5e, has had considerable attention, in part due to the current global climate warming and its implications for global ice volume reduction and corresponding sea level rise. All studies agree that during MIS 5e, sea level was higher than at present, with recent studies suggesting that it was higher even than the previous long-standing estimates of $+2-6 \mathrm{~m}$ (e.g. Neumann \& Hearty, 1996; Stirling et al., 1998; McCulloch \& Esat, 2000). Moreover, results from recent studies now suggest that there were sea level oscillations during MIS 5e, resulting in more than one peak in sea level during this time. Using their stable oxygen isotope records from the Red Sea, in combination with dated coral terraces from previous investigations, Rohling et al. (2008) calculate an average mean highstand for MIS 5e of up to $+6 \mathrm{~m}$ (higher than present sea level), with evidence for peaks of up to $+9 \mathrm{~m}$. Using a compilation of previously published sea level data from $>40$ different sites around the world, Kopp et al. (2009) undertook a probabilistic assessment of sea level during MIS 5e. Their results showed a $95 \%$ probability that it had exceeded $+6.6 \mathrm{~m}$ during the last interglacial. Recently published data, based on radiometric dating, have estimated sea level for MIS $5 \mathrm{e}$ at $+6 \mathrm{~m}$ from fossil reefs in the Bahamas (Thompson et al., 2011), and $+6.7 \pm 1.7 \mathrm{~m}$ based on ${ }^{18} \mathrm{O}$ records from the eastern Mediterranean (Grant et al., 2012). In the most recent review of global data which also takes into consideration glacio-hydro-isostatic effects, Dutton \& Lambeck (2012) argue that $+5.5-9 \mathrm{~m}$ higher than present during MIS 5e. 
As with MIS 5e, recently published data have shown that MIS 5a and 5c were not simple events and also likely experienced sea level oscillations within each highstand. Furthermore, estimates of peak sea level for MIS 5a and 5c vary widely depending on the study site, due to stronger glacio-hydro-isostatic effects during these periods, as a consequence of growth of Northern Hemisphere ice sheets whose load weighed down the earth's crust beneath, causing it to subside (Potter \& Lambeck, 2004; Lambeck, 2004 and references therein). For instance, during MIS $5 \mathrm{a}$, estimates of sea level tend to be higher when determined from sites nearer to former ice margins, with published estimates from near-field sites of $-16 \mathrm{~m}$ (Thompson \& Goldstein (2005) using radiometric ages from corals in Barbados) and -10 m (Dumas et al., (2006), based on radiometric dating of coral terraces in Haiti). Values from further afield yielded sea level estimates in the range of $-27 \mathrm{~m}$ (Chappell et al., 1996; radiometric dating of coral terraces at Huon Peninsula, Papua New Guinea), between -40 and -30 m (Rohling et al., 2008), and -35.2 $\pm 3.1 \mathrm{~m}$ (Grant et al., 2012). Likewise, estimates of sea level during MIS 5c from sites closer to these ice sheets produced values of $-14 \mathrm{~m}$ (Thompson \& Goldstein, 2005), -8 m (Dumas et al., 2006), and -17 m (Rohling et al., 2008), while records from further afield suggests sea level was much lower, for example $-30.2 \pm 3.1 \mathrm{~m}(2 \sigma)$ (Grant et al., 2012). Therefore, data from the Northern Hemisphere, especially those sites close to former ice margins, need to be corrected for glacio-hydro-isostatic effects. This in itself is nontrivial, given that these effects depend on the extent of ice loading during the preceding glacial and interglacial periods, the current estimates of which are being challenged (Eelco Rohling, pers. comm., March 2017). To reduce uncertainty in the variable sea level estimates for MIS 5c and 5a, Creveling et al. (2017) considered published regional sea level estimates, as determined from geomorphic paleo-sea level indicators, from 38 sites across the world. The data were included in a sensitivity analysis, which incorporated glacial isostatic adjustment simulations, to constrain peak global sea level bounds for MIS $5 \mathrm{a}$ to $\sim 4-16 \mathrm{~m}$ and for MIS $5 \mathrm{c}$ to $\sim 4-18 \mathrm{~m}$ below present.

\subsection{Methods}

\subsubsection{Terrace chronology}

In Chapter 3, I described the OSL sample collection processes and analysis techniques used to determine the age of the marine terraces along the south coast of the North Island. I made the assumption that shore platforms were cut during sea level highstands (or stillstands) and used the OSL results to guide my assessment of the relevant, formative marine isotope stage (MIS). All MIS ages are quoted from Lisiecki and Raymo (2005). In Chapter 3, I describe the marine terraces distribution and stratigraphy in detail by site. Terraces were names T1, T2, T3 etc. 
depending on their position in the terrace sequence at each site, with $\mathrm{T} 1$ being the youngest and lowest terrace, $\mathrm{T} 2$ being the second youngest, etc. As such, terrace ' $\mathrm{T} 1$ ' at one site may not necessarily correspond in age with terrace ' $\mathrm{T} 1$ ' of any other site; the same terrace number between different sites does not imply any correlation. To simplify matters, in this chapter, I re-name the terraces based on the MIS they correspond to. A summary of the terraces as they are referred to in Chapter 3, and their MIS name used in this chapter, is provided in Table 4A.

Table 4A. Terrace names used in this chapter, based on MIS during which they formed. MIS correlations are constrained by OSL ages, except for terraces in italics, which are inferred.

\begin{tabular}{|c|c|c|c|c|c|c|c|}
\hline \multirow{2}{*}{$\begin{array}{c}\text { Terrace } \\
\text { Name }\end{array}$} & $\begin{array}{c}\text { MIS } \\
\text { (Peak) } \\
\text { (ka) }\end{array}$ & \multicolumn{5}{|c|}{ (Field Site and Local Terrace Name, as referred to in Chapter 3) } \\
\cline { 3 - 8 } & $\begin{array}{c}\text { Tongue } \\
\text { Point }\end{array}$ & $\begin{array}{c}\text { Baring } \\
\text { Head }\end{array}$ & Wharekauhau & $\begin{array}{c}\text { Lake Ferry } \\
\text { to Te Kopi }\end{array}$ & $\begin{array}{c}\text { Washpool/ } \\
\text { Whatarangi }\end{array}$ & $\begin{array}{c}\text { Te Humenga to } \\
\text { Cape Palliser }\end{array}$ \\
\hline MIS 5a & 82 & TP-T1? & BH-T1 & & & WW-T1 & \\
\hline MIS 5c & 96 & TP-T1? & & & PB-T1 & & WW-T2? \\
\hline MIS 5e & 123 & TP-T2 & BH-T2 & & TH-T1 \\
\hline MIS 7a & 196 & TP-T3 & BH-T3 & WH-T1 & & & \\
\hline
\end{tabular}

\subsubsection{Strandline elevation calculations}

The elevation measurement required to calculate uplift is that of the ancient shoreline, also called the shoreline angle, or strandline. The strandline approximately coincides with the most landward extent of the shore platform; the back edge, at the base of the ancient sea cliff, assumed to have been cut at mean sea level (see Fig. 3.2). Exposures of the strandline in bedrock, however, were not found during this study, due to cover bed deposits of variable thickness obscuring them. For this reason, the position and corresponding elevation of the strandline beneath the younger coverbeds had to be calculated.

This was done by first calculating the mean planar attitude of the shore platform (or strath) at each site. As described in the Methods section of Chapter 3, I measured shore platform elevations using Global Navigational Satellite Systems (GNSS) surveying. The data collection uncertainties (instrumental and human) were small, $<30 \mathrm{~cm}$, compared to the natural variation in the shore platform topography, so each point was assigned a geological uncertainty of $\pm 3 \mathrm{~m}$. 
These shore platform elevation points $(\mathrm{x}, \mathrm{y}, \mathrm{z})$, were then used to calculate a plane of best fit, with the mean of the data points assumed to be on that plane. The corresponding normal vector was then used to calculate the coefficients of the plane, including both its position and its attitude. The accuracy of the fitted plane depends on the number of elevation points used, the effects of any outliers within the elevation dataset (for instance, measuring local lows due to channels, or highs due to stacks on the shore platform) and the spatial distribution of the data points. To indicate how good a fit the calculated plane is to the original surveyed data, for each plane, I calculated the average distance of each surveyed elevation point to that plane, which I refer to the residual of the fit - the smaller the residual, the better the fit. Details of the elevation dataset used to calculate individual shore platform planes, their orientation and residual values, are provided in Appendix D.

The position and elevation of the paleo-strandline was determined using a series of profiles. These were constructed parallel to the calculated dip of the shore platform. Because the paleoshoreline is located at the intersection of the shore platform and the ancient sea cliff behind it, for each profile, the shore platform surface was projected (with the appropriate dip angle) from a surveyed exposure towards the ancient sea cliff at the rear of the terrace. Since the slope of the ancient sea cliff has been modified by subsequent erosion and deposition, its slope was estimated for each profile using the slope of the local modern-day sea cliff as an analogue for that site. This slope was projected from the mid-point of the current-day profile of the ancient sea cliff, assuming that the mid-point is least modified by erosion (which is most likely to be experienced at the top of the sea cliff) and least obscured by colluvial deposition (likely to occur at the bottom of the sea cliff). On each profile, the intersection of these two lines representing the shore platform and ancient sea cliff - provided the elevation of the strandline for that site. The uncertainty value of each calculated strandline elevation is dependent on how well the calculated shore platform 'fit' the surveyed elevation data at that site. I have used the residual of the plane fit (the average distance of each surveyed elevation point to the corresponding calculated shore platform) (see Appendix D) to define this uncertainty.

\subsubsection{Uplift Calculations}

Because sea level has changed through time, the true amount of uplift experienced by a shore platform since its formation at sea level is not simply its current-day elevation, but is calculated by the difference between the present-day shore platform elevation and paleo-sea level during its formative highstand. In the Background section of this chapter, I discussed the published data on sea level elevation estimates for each of the highstands during which our terraces 
formed - MIS 7a, 5e, 5c and 5a. For my uplift calculations, for MIS 7a I apply the overlapping values of the estimates of Bard et al. (2002), Siddall et al. (2007), and Grant et al. (2012; 2014) of 9-15 m below present. For MIS 5e, I employ estimates from one of the most recent reviews of global data which also takes into consideration glacio-hydro-isostatic effects, by Dutton \& Lambeck (2012), which gives sea level at 5.5-9 m higher than present. During MIS 5a and 5c, I look to estimates by Creveling et al. (2017) who undertook a sensitivity analysis which incorporated glacial isostatic adjustment simulations; their peak global sea level bounds for MIS 5a and for MIS 5c are $\sim 4-16 \mathrm{~m}$ and $\sim 4-18 \mathrm{~m}$ below present, respectively. Although applying these eustatic sea level estimates to the lower North Island means that any local glaciohydro-isostatic effects are not taken into consideration, it is likely that such effects to New Zealand are small; Clements et al. (2016) suggest that glacio-hydro-isostatic effects influenced sea level in the lower North Island by $<1 \mathrm{~m}$ during the Holocene.

As I have correlated the Pleistocene terraces along the south coast of the North Island to a MIS, I apply the age of that MIS at the time of peak sea level, with ages provided by Lisiecki \& Raymo (2005).

To calculate uplift, I apply the equation:

Uplift Rate $(\mathrm{mm} / \mathrm{yr})=$ Strandline elevation (corrected) (m)/ MIS Peak Age (ka)

Although uplift is more accurately determined from strandline elevations, in some instances, where a strandline elevation could not be reconstructed, I have used a surveyed shore platform elevation measurement to estimate a minimum uplift rate for that site.

The uncertainties in the uplift rate calculations consider i) the geologically-observed variability of each surveyed elevation point of $\pm 3 \mathrm{~m}(1 \sigma)$ (see Chapter 3 Methods and this chapter section 4.3.2); this uncertainty was included in the shore platform best-fit plane calculations; ii) the residual value of each calculated shore platform plane, representing the average distance each surveyed shore platform elevation point was from the calculated best-fit plane, which ranged from $0.1 \mathrm{~m}$ to $8.3 \mathrm{~m}$ (values calculated for each shore platform are listed in Appendix D); the residual value of each shore platform was then assigned as the uncertainty to the calculated strandline elevation of that shore platform, as shown in the 'Strandline' column of Table 4B; iii) the full range in sea level estimated for each MIS under consideration, namely -4 to $-16 \mathrm{~m}$

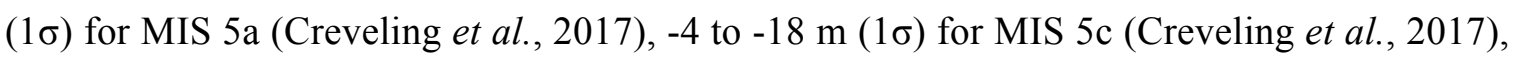
+5.5 to $+9 \mathrm{~m}(1 \sigma)$ for MIS 5e (Dutton \& Lambeck, 2012), and -9 to $-15 \mathrm{~m}(1 \sigma)$ for MIS $7 \mathrm{a}$ (Bard et al., 2002; Siddall et al., 2007; Grant et al., 2012; 2014). 
To obtain a conservative estimate, the quoted uplift rate uncertainty combines the residual value of the shore platform plane, which is assigned to the strandline elevation, (or the geological uncertainty of $\pm 3 \mathrm{~m}$ if uplift has been calculated from the shore platform), and the sea level range at the time that it formed. For example, the uplift rate at Wharekauhau was calculated by first correcting the present-day strandline elevation, of $17.9 \pm 3.0 \mathrm{~m}$, for sea level during MIS 7a, when the shore platform was cut. Sea level during MIS 7a has been estimated as being between 9 and $15 \mathrm{~m}$ below present (Bard et al., 2002; Siddall et al., 2007; Grant et al., 2012; 2014). Combining these uncertainties results in a conservative estimate of actual uplift for this strandline of $29.9 \pm 6.0 \mathrm{~m}$. Then, using the equation above:

Uplift Rate $(\mathrm{mm} / \mathrm{yr})=29.9 \pm 6.0 \mathrm{~m}$ (strandline elevation corrected)/ $196 \mathrm{ka}$ (MIS 7a peak age) yields an uplift rate of $0.2 \pm 0.1 \mathrm{~mm} / \mathrm{yr}$ for this shore platform.

\subsection{Results}

\subsubsection{Strandline Elevations \& Uplift Rates}

In this section I present shore platform attitudes (strike/dip/dip direction) and the profiles created to determine the strandline elevations of the Pleistocene terraces preserved along the south coast of the North Island of New Zealand. I use the reconstructed strandline elevations, (corrected for sea level during the relevant, formative highstand) to calculate uplift rates. Calculations have been made for four different-aged shore platforms, corresponding to MIS 5a, MIS 5c, MIS 5e and MIS 7a, and are described by field site, presented west to east. Results are summarised in Table 4B.

\subsubsection{Tongue Point}

There are three Pleistocene marine terraces preserved at Tongue Point. Although not dated, the youngest has been inferred as MIS 5c (or possibly MIS 5a), based on its position in the terrace sequence; it is lower than the main terrace at this site which has been dated and correlates with MIS 5e. One older, higher terrace is inferred to have formed during MIS 7a. The terraces are offset by the Ohariu Fault, such that the western terraces are uplifted relative to those on the eastern side of the fault (Fig. $4.5 \mathrm{a}$ ).

A plane of best fit and associated strandline could not be calculated for the youngest Pleistocene terrace at Tongue Point; with only a few remnant stacks of this feature remaining, there were too few exposures of the shore platform from which to collect elevation measurements. Instead, I use surveyed shore platform elevations of $16 \pm 3 \mathrm{~m}$ on the west of the fault, and $7 \pm 3 \mathrm{~m}$ on 
the east, to calculate minimum uplift rates. These elevations yield values of $0.3 \pm 0.1 \mathrm{~mm} / \mathrm{yr}$ for the western, upthrown side of the Ohariu Fault and $0.2 \pm 0.1 \mathrm{~mm} / \mathrm{yr}$ for the downthrown side, whether the shore platform was cut during MIS 5a (82 ka) or MIS 5c (96 ka).

Strandline elevations were calculated for the MIS 5e shore platform. On the western side of the Ohariu Fault, there were only three exposures of the shore platform from which to collect elevation data. The shore platform attitude calculated from these three points, of 090/8.8 $\mathrm{N}$, shows it dipping away from the current-day coast. This could due to an erroneously high elevation point at the front, coastal extent of the terrace, or due to localised deformation by the Ohariu Fault. For this reason, a strandline elevation was not calculated for this shore platform. Instead, in this instance, I use a surveyed shore platform exposure elevation of $75 \pm 3 \mathrm{~m}$ to calculate a minimum uplift rate of $0.6 \pm 0.1 \mathrm{~mm} / \mathrm{yr}$ since $123 \mathrm{ka}$.

A greater number of shore platform exposures and corresponding elevation measurements of the MIS 5e shore platform were available on the eastern side of the Ohariu Fault at Tongue Point, where the shore platform attitude was determined as $122 / 7.8^{\circ} \mathrm{S}$. However, the calculated plane-of-best-fit has large uncertainties, with an average distance of each surveyed elevation point to the calculated plane of $28.5 \mathrm{~m}$. Nonetheless, I attempted to calculate the strandline elevation from two profiles (see Fig. 4.5 b, c). Profile A shows the strandline exposed above the current-day topography, which suggests at the very least that the shore platform would now be exposed at the surface at this site, which it is not. Profile B has the shore platform beneath the current-day surface, however the elevations of the calculated strandline, $78.6 \pm 28.5 \mathrm{~m}$ suggests that this surface is near in elevation to the shore platform of the MIS 7a terrace, which is exposed at $82.7 \pm 3 \mathrm{~m}$; this did not appear to be the case in field observations. Both strandline reconstructions suggest that the dip of the shore platform on this eastern side of the Ohariu Fault has been over-estimated by our plane-of-best-fit calculation method. A reason for this is that the shore platform orientation on this eastern side of the Ohariu Fault has been calculated from two clusters of elevation data. The data are consistent within each cluster, but the elevations at each cluster are quite different, with values of $\sim 27-29 \mathrm{~m}$ near Profile A and elevations of $\sim 45-48 \mathrm{~m}$ from the easternmost data, near Profile B. I infer that this shore platform, to the east of the Ohariu Fault, has been deformed by movement on the Ohariu Fault, and/or that the site of the cluster of elevation data near 'Profile A' may represent an eroded topographic low, possibly due to this area being near the mouth of the Waiariki Stream. This latter scenario is consistent with the shore platform here being on the eastern, down-thrown side of the Ohariu Fault; while rupture has uplifted the shore platform away from marine erosion processes to the west of the fault, the eastern side, especially the region closest to the 


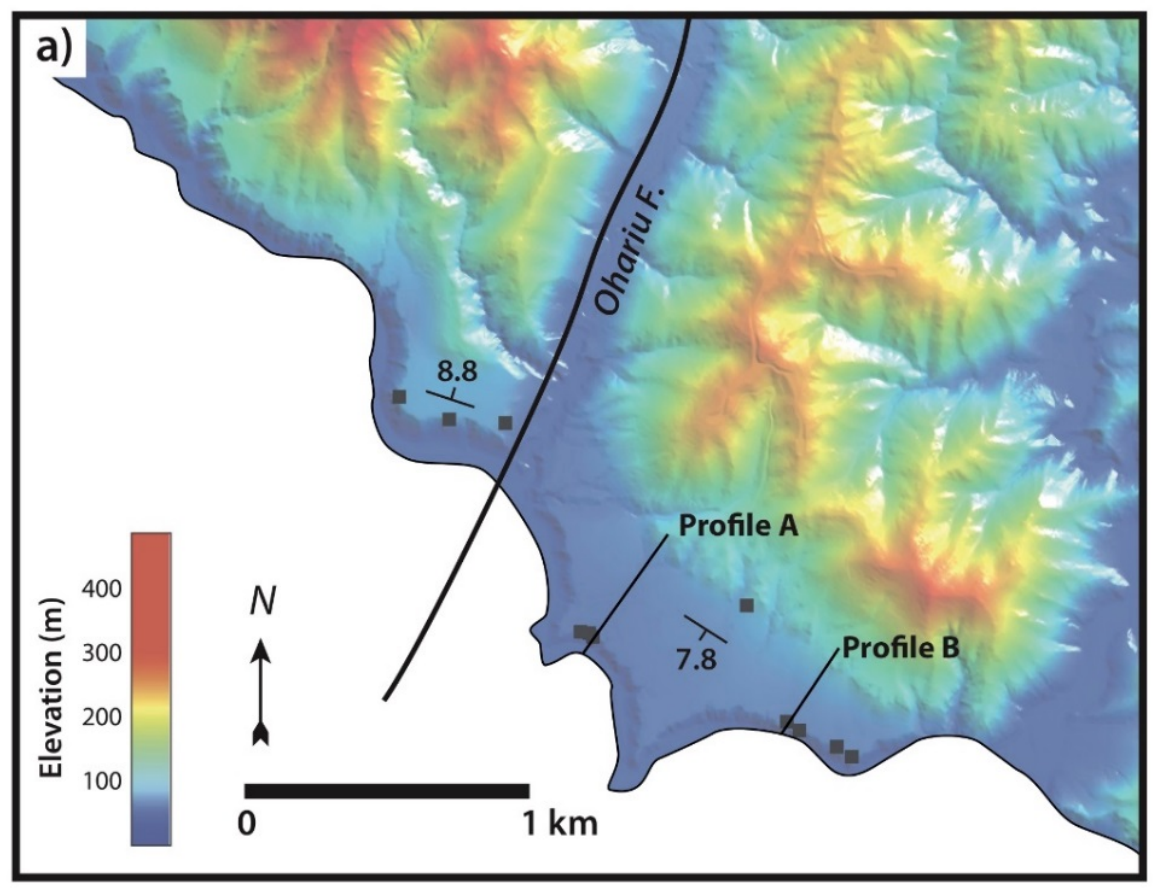

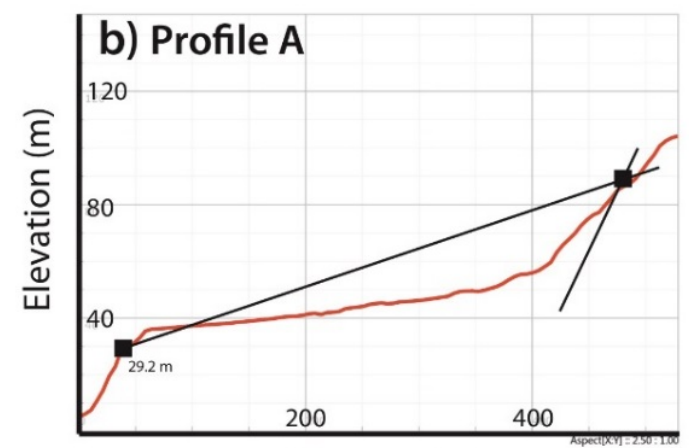

Distance $(\mathrm{m})$

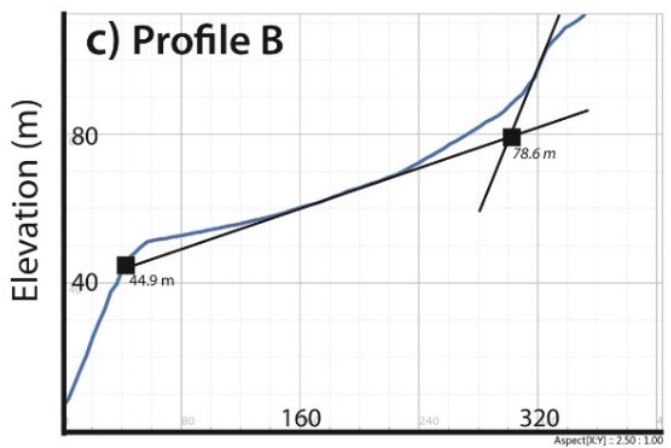

Distance $(\mathrm{m})$

Figure 4.5. a) Pleistocene marine terraces at Tongue Point, showing the location of the Ohariu Fault and strandline elevation profiles, on digital terrace data backdrop (courtesy GWRC; b) Profile A; c) Profile B.

fault, may have been repeatedly downthrown to coastal levels and therefore exposed to marine erosion for a greater amount of time. As such, I consider the uplift rate of $\sim 0.6 \mathrm{~mm} / \mathrm{yr}$ for the last $123 \mathrm{ka}$, calculated from the strandline reconstruction from 'Profile B', as a maximum for this down-thrown side of the Ohariu Fault. To constrain uplift for this side further, I use a shore platform elevation surveyed near to the fault, of $27.0 \pm 3 \mathrm{~m}$, to yield a minimum uplift rate of $0.2 \pm 0.1 \mathrm{~mm} / \mathrm{yr}$ on this downthrown side of the Ohariu Fault.

The difference in uplift observed between the two MIS 5e shore platforms on either side of the Ohariu Fault, of $0.6 \pm 0.1 \mathrm{~mm} / \mathrm{yr}$ on the upthrown side and $0.2 \pm 0.1 \mathrm{~mm} / \mathrm{yr}$ on the downthrown side, suggests a vertical slip rate on this fault of $\sim 0.4 \mathrm{~mm} / \mathrm{yr}$ at Tongue Point. 
A surveyed shore platform elevation of $82.7 \pm 3 \mathrm{~m}$ from the MIS 7 a terrace preserved to the east of the Ohariu Fault, yields a minimum uplift rate of $0.5 \pm 0.1 \mathrm{~mm} / \mathrm{yr}$ since $196 \mathrm{ka}$.

\subsubsection{Baring Head}

There are six Pleistocene terraces preserved at Baring Head, the youngest three of which have been correlated to MIS 5a, MIS 5e and MIS 7a, with the ages of the youngest and oldest of these three being constrained by OSL analysis. The terraces are dissected by the Baring Head Fault, the Wainuiomata River, and another unnamed fault (Fig. 4.6 a). Due to the potential tectonic deformation of the shore platform by the two faults, shore platform orientation calculations were considered separately west of the Baring Head Fault, between the Baring Head and un-named fault, and east of the unnamed fault.

There are too few shore platform elevation measurements to the west of Baring Head Fault to attempt to calculate a MIS 5a terrace shore platform attitude and corresponding strandline elevation at this location. Instead, a surveyed shore platform elevation of $79.1 \pm 3 \mathrm{~m}$ is used to calculate a minimum uplift rate of $1.1 \pm 0.1 \mathrm{~mm} / \mathrm{yr}$ here, on the upthrown side of the Baring Head Fault, for the last $82 \mathrm{ka}$ yr. In order to quantify vertical deformation across the Baring Head fault, I use a shore platform elevation measurement of $66.2 \pm 3 \mathrm{~m}$ which was surveyed directly on the other side of the fault. This yields a minimum uplift rate of $0.9 \pm 0.1 \mathrm{~mm} / \mathrm{yr}$ for the downthrown side of the Baring Head Fault. The difference between the uplift rates calculated for either side of the Baring Head Fault suggest that this structure has a vertical slip rate of $\sim 0.2 \mathrm{~mm} / \mathrm{yr}$ at this location.

Between the Baring Head Fault and the unnamed fault, a shore platform attitude of 136/3.0 SW was calculated for the MIS 5a terrace. Here, two profiles were constructed to determine the strandline elevation (Fig. 4.6 b, c). Strandline elevations determined from Profile A and Profile $B$ are consistent, with values of $82.8 \pm 4.7 \mathrm{~m}$ and $89.8 \pm 4.7 \mathrm{~m}$. From these elevations I calculate uplift rates of $1.1 \pm 0.1 \mathrm{~mm} / \mathrm{yr}$ and $1.2 \pm 0.1 \mathrm{~mm} / \mathrm{yr}$, respectively, for the MIS 5a terrace at Baring Head since 82 ka.

To quantify vertical deformation across the un-named fault that offsets the MIS 5a terrace at Baring Head, I used a surveyed elevation measurement from either side of the fault. To the west and on the downthrown side of the un-named fault, from a shore platform exposure at $108.5 \pm 3 \mathrm{~m}$, I have calculated a minimum uplift rate of $1.5 \pm 0.1 \mathrm{~mm} / \mathrm{yr}$. To the east of the fault, a minimum uplift rate of $1.6 \pm 0.1 \mathrm{~mm} / \mathrm{yr}$ was calculated from a shore platform elevation measurement of $120.5 \mathrm{~m} \pm 3$. The difference between the uplift rates calculated on either side of this fault gives a vertical slip rate on this structure of $\sim 0.1 \mathrm{~mm} / \mathrm{yr}$ for the last $82 \mathrm{ka}$. However, 
the uplift rates have been calculated from points $\sim 300-350 \mathrm{~m}$ on either side of the fault; this, in combination with the shore platform tilting to the west and the fault uplifting the eastern side, results in an over-estimate in the calculated vertical slip rate of this structure.
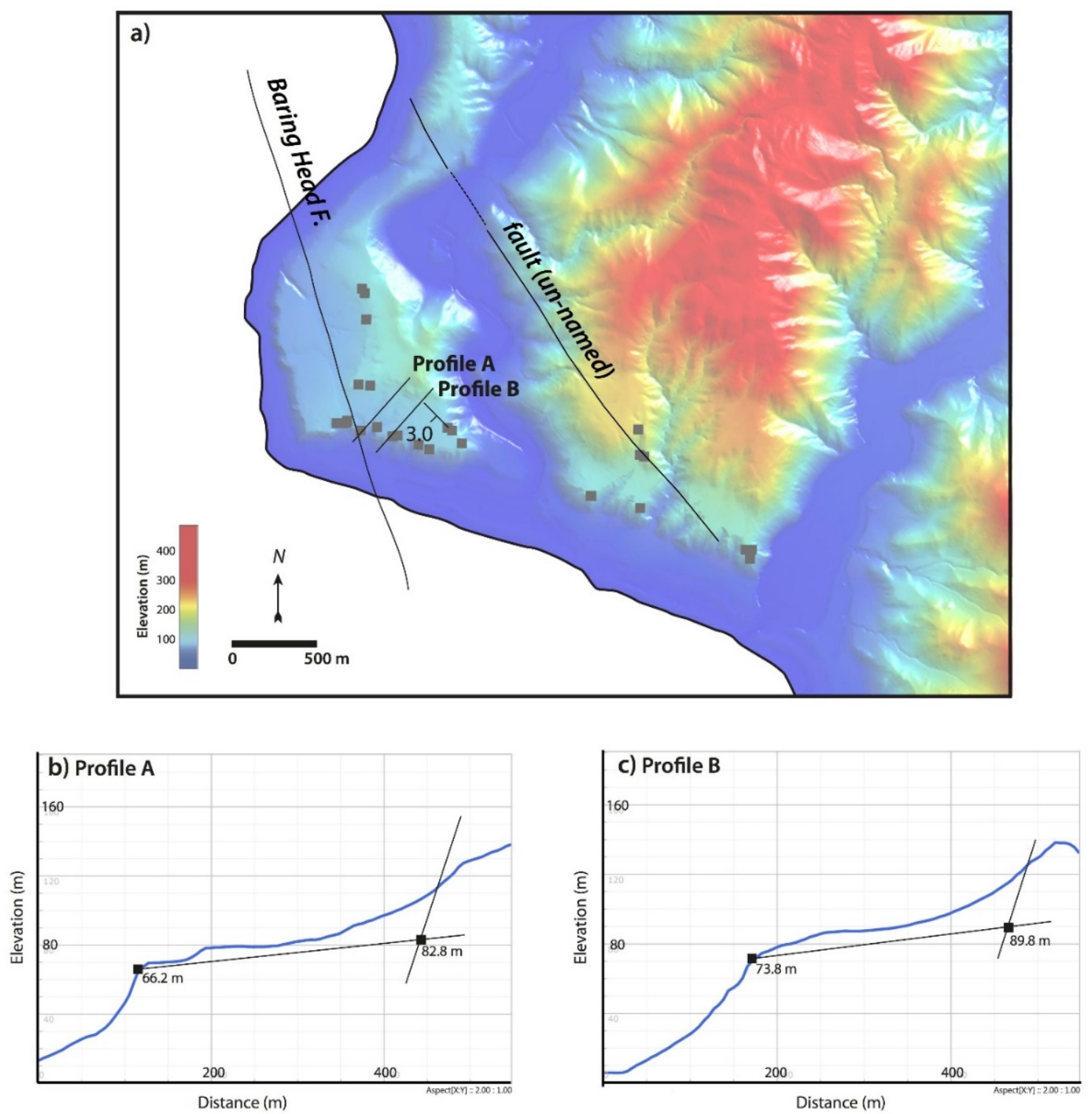

Figure 4.6. a) Pleistocene marine terraces at Baring Head, showing the location of the Baring Head Fault and un-named fault, and strandline elevation profiles, on digital terrace data backdrop (courtesy GWRC; b) Profile A; c) Profile B. 
A narrow strip ( $\sim 100 \mathrm{~m}$ at its widest point) of the inferred MIS 5e terrace is preserved at Baring Head (T2 in Fig. 3.5, Chapter 3), between the Baring Head Fault and the un-named fault. Due to the small number of elevation data points collected from the shore platform, I have not attempted to calculate a shore platform attitude or corresponding shoreline elevation for this terrace. Instead, I use the elevations surveyed directly from the shore platform exposures, in particular one elevation measurement from the rear of the terrace, near to where the strandline would be located. The elevation here is $95.8 \pm 3 \mathrm{~m}$, which yields an uplift rate of $0.7 \pm 0.1 \mathrm{~mm} / \mathrm{yr}$.

Similarly, the limited size of what remains of the inferred MIS 7a terrace at Baring Head (T3 in Fig. 3.5, Chapter 3), coupled with the limited elevation data available from shore platform exposures of this terrace, does not warrant a calculation of the attitude of the shore platform and strandline elevation. Instead, I use a shore platform elevation of $173.6 \mathrm{~m} \pm 3 \mathrm{~m}$ to calculate a minimum uplift rate of $1.0 \pm 0.1 \mathrm{~mm} / \mathrm{yr}$ at this location since $196 \mathrm{ka}$.

\subsubsection{Wharekauhau}

One terrace is preserved along the coast between Wharekauhau and Lake Onoke, whose associated shore platform has been identified to be MIS 7a in age (Fig. 4.7 a). The OSL ages obtained from marine deposits overlying this shore platform range in ages which correspond to all the main highstands of MIS 5 (Schermer et al., 2009), through to MIS 7a (this study), and this has been interpreted to indicate that this shore platform was occupied by the sea during all of these highstands. The orientation of the shore platform along this stretch of coast has been calculated as $132 / 0.2^{\circ} \mathrm{SW}$. Two profiles were constructed across this terrace (Fig. $4.7 \mathrm{~b}, \mathrm{c}$ ), providing two strandline elevations of $17.9 \pm 3.0 \mathrm{~m}$ and $15.5 \pm 3.0 \mathrm{~m}$. These yield uplift rates of $0.2 \pm 0.1 \mathrm{~mm} / \mathrm{yr}$ and $0.1 \pm 0.1 \mathrm{~mm} / \mathrm{yr}$, respectively, for this site since $196 \mathrm{ka}$.

\subsubsection{Lake Ferry - Te Kopi}

OSL dating identifies the main coastal terrace preserved between Lake Ferry and Te Kopi as MIS $5 \mathrm{c}$ in age. As detailed in Chapter 3, field mapping of this terrace, in combination with analysis of shore platform elevation data, identified a fault offset near Whangaimoana Beach of $\sim 3$ m uplifted to the west. This offset most likely occurs on the coastal extension of the Pirinoa Fault, which has been mapped further inland (e.g. Begg \& Johnston, 2000). As such, the orientation of the shore platform and strandline were calculated separately for either side of this fault (Fig. 4.8 a).

West of the fault, the shore platform has a calculated orientation of $156 / 0.7^{\circ} \mathrm{W}$. One profile was constructed at this location, 'Profile A' (Fig. 4.8 b), and the strandline on this profile was located at an elevation of $61.1 \pm 0.1 \mathrm{~m}$. This yields an uplift rate from the MIS 5c terrace near Lake Ferry 
of $0.8 \pm 0.1 \mathrm{~mm} / \mathrm{yr}$ since $96 \mathrm{ka}$. Near to the Pirinoa Fault, uplift rates determined from surveyed shore platform elevations of $41.11 \pm 3 \mathrm{~m}$ on the western, upthrown side yields a minimum uplift rate of $0.5 \pm 0.1 \mathrm{~mm} / \mathrm{yr}$. To the east of the fault, a shore platform elevation of $39.1 \pm 3$ yields a minimum uplift rate of $0.5 \pm 0.1 \mathrm{~mm} / \mathrm{yr}$. On the eastern side of the Pirinoa Fault, the shore platform has an orientation of $030 / 0.6^{\circ} \mathrm{W}$. Near Te Kopi, at the eastern end of this area, 'Profile B' (Fig. 4.8 c), gives a strandline elevation of $94.9 \pm 0.4 \mathrm{~m}$. This elevation yields an uplift rate of $1.1 \pm 0.1 \mathrm{~mm} / \mathrm{yr}$ for the last $96 \mathrm{ka}$.
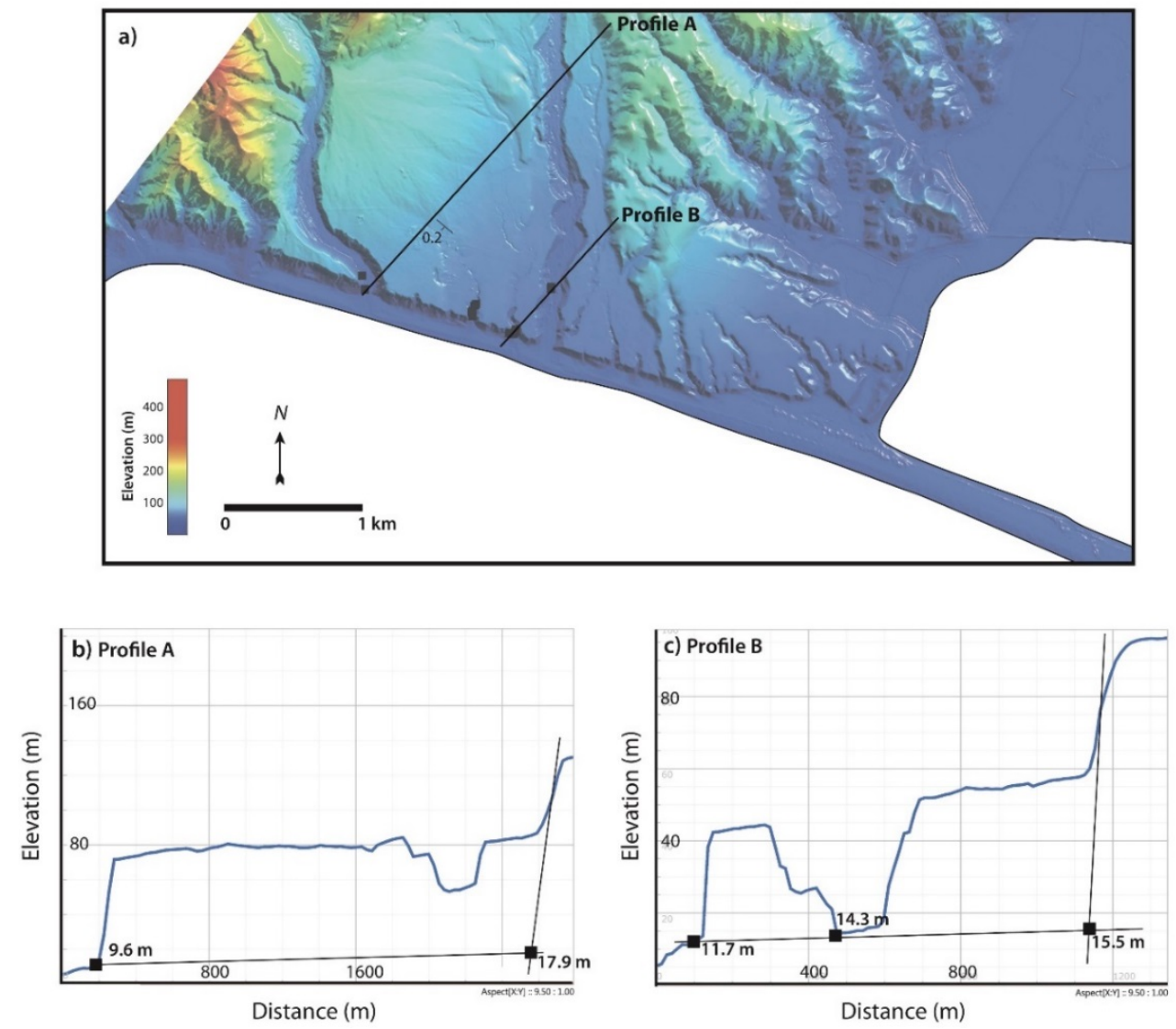

Figure 4.7. a) Pleistocene marine terraces at Wharekauhau, showing fault locations and strandline elevation profiles, on digital terrace data backdrop (courtesy GWRC; b) Profile A; c) Profile B.

\subsubsection{Washpool/Whatarangi}

The age of the main coastal terrace at Washpool/Whatarangi has been constrained by OSL dating as MIS 5a. At the southern end of the site, a higher terrace preserved locally along the coast is inferred to be MIS 5e in age; this terrace then curves inland and is preserved behind the MIS 5a terrace (Fig. 4.9 a). 

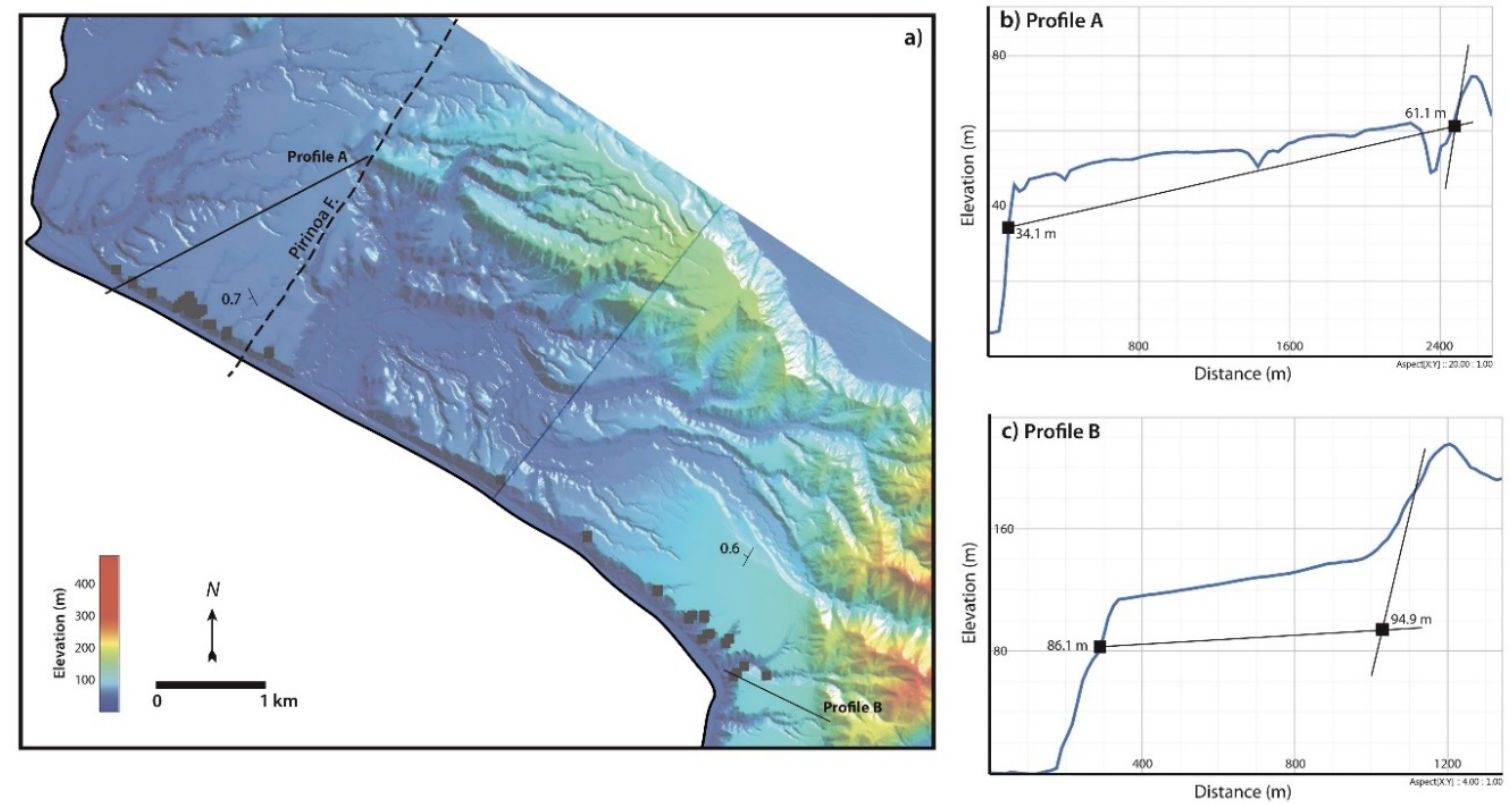

Figure 4.8. a) Pleistocene marine terraces between Lake Ferry and Te Kopi, showing location of strandline elevation profiles and approximate location of the Pirinoa Fault, on digital terrace data backdrop (courtesy GWRC); b) Profile A; c) Profile B.
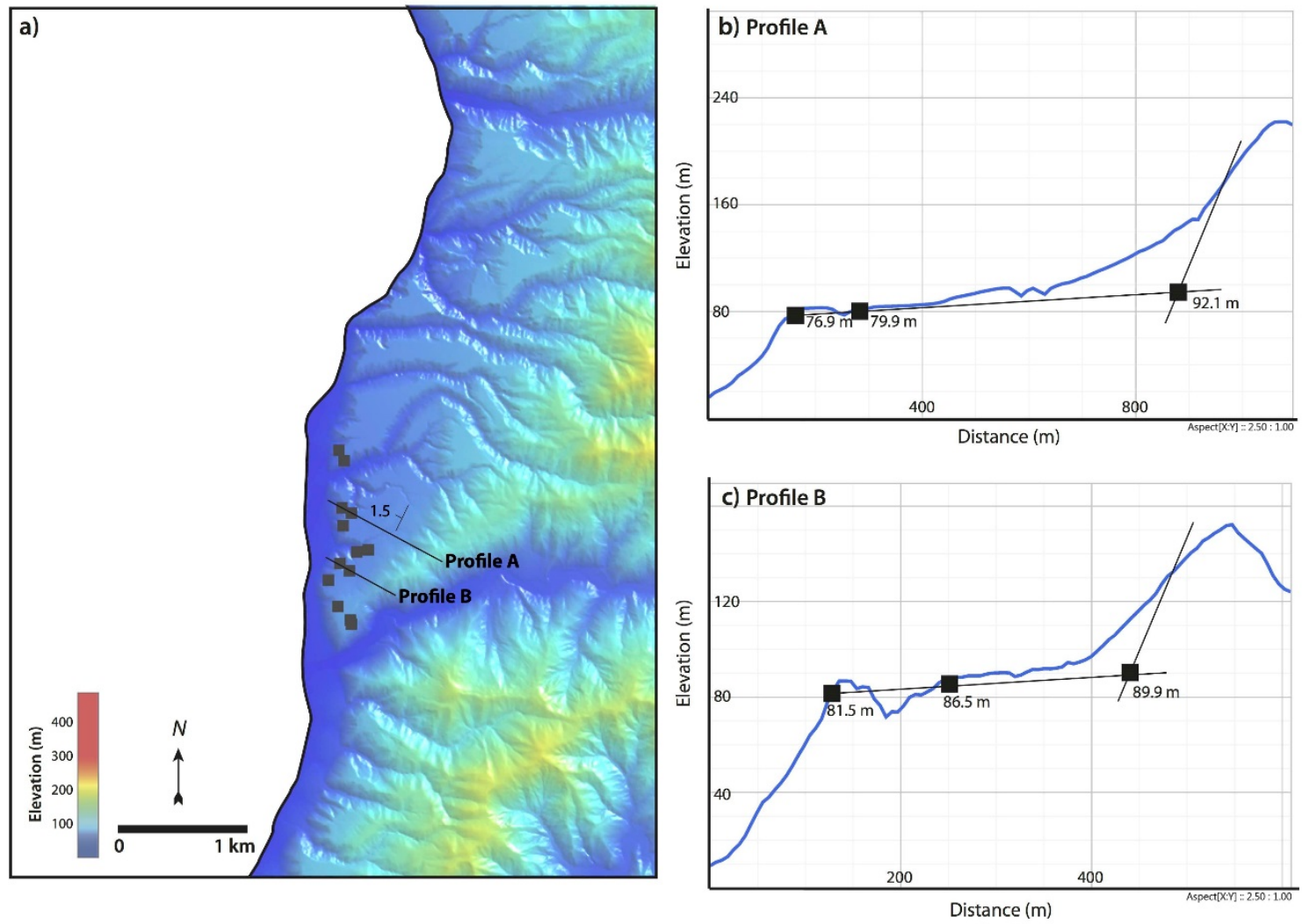

Figure 4.9. a) Pleistocene marine terraces at Washpool/Whatarangi, showing strandline elevation profiles, on digital terrace data backdrop (courtesy GWRC; b) Profile A; c) Profile B. 
The orientation of the MIS 5a shore platform at Washpool/Whatarangi has been calculated as 025/1.5 W. In an attempt to calculate the strandline elevation, two profiles were constructed. The strandline elevations determined from the two profiles are similar; $92.1 \pm 0.7 \mathrm{~m}$ and 89.9 $\pm 0.7 \mathrm{~m}$ (Fig. $4.9 \mathrm{~b}, \mathrm{c}$ ). These values yield uplift rates of $1.3 \pm 0.1 \mathrm{~mm} / \mathrm{yr}$ and $1.2 \pm 0.1 \mathrm{~mm} / \mathrm{yr}$, respectively, for the last $82 \mathrm{ka}$ from the MIS 5a terrace at this site.

The higher terrace preserved along the coast at Washpool/Whatarangi has been inferred to be MIS 5e in age, based on the shore platform and terrace tread elevations, which in the field appear to be approximately consistent with those of the MIS 5e terrace preserved further southeast, between Te Humenga and Cape Palliser. Unfortunately there were too few shore platform exposures for the MIS 5e terrace preserved locally at Washpool/Whatarangi from which to calculate a shore platform orientation and strandline elevation for the MIS 5e terrace at this site. Instead, I use a surveyed shore platform elevation of $114.0 \pm 3.0 \mathrm{~m}$ to calculate a minimum uplift rate from this terrace of $0.9 \pm 0.1 \mathrm{~mm} / \mathrm{yr}$. As mentioned, this terrace was inferred to be MIS 5e in age based on the terrace tread elevation being near-consistent with the dated MIS 5e terraces preserved almost continuously between Te Humenga and Ngawi. If the inferred age for this terrace of MIS 5e is incorrect, and this terrace is instead MIS 5c in age, then the calculated uplift rate would be $1.3 \pm 0.1 \mathrm{~mm} / \mathrm{yr}$, which is within error of the rates calculated from the dated MIS 5 a terrace at this site.

\subsubsection{Te Humenga Point - Cape Palliser}

There is one main terrace preserved between Te Humenga Point and Cape Palliser (Fig. 4.10, Fig. 4.11), and based on our OSL analysis this terrace correlates to MIS 5e. Due to the distance over which this terrace is discontinuously preserved ( $\sim 10 \mathrm{~km}$ along the coast), I analysed the elevation data at Te Humenga and Ngawi separately, to assess whether the shore platform attitude is consistent between these locations. Where it is preserved at Te Humenga, the shore platform has a calculated orientation of 169/2.5 W (Fig. 4.10 a). The calculation of the orientation of the shore platform at Ngawi yielded a similar result of 173/2.9 W (Fig. $4.11 \mathrm{a}$ ).

Five strandline elevations were calculated for this terrace, two from the terrace preserved at Te Humenga (Fig. 4.10 b, c), two from the terrace preserved near Ngawi (Fig. 4.11 b, c), and one profile in between (Fig. $4.11 \mathrm{~d}$ ). The two profiles constructed at Te Humenga give consistent strandline elevations of $193.4 \pm 2.0 \mathrm{~m}$ and $195.9 \pm 2.0 \mathrm{~m}$. These strandline elevation yield an uplift rate of $1.5 \pm 0.1 \mathrm{~mm} / \mathrm{yr}$ for the last $123 \mathrm{ka}$ yr at this location. At Ngawi, the two calculated strandline elevations were again consistent, yielding values of $213.6 \pm 8.3 \mathrm{~m}$ and $211.1 \pm 8.3$ $\mathrm{m}$. Using these strandline elevations gives an uplift rate of $1.7 \pm 0.1 \mathrm{~mm} / \mathrm{yr}$ for the last $123 \mathrm{ka}$ 
from the MIS 5e terrace at Ngawi. The profile constructed in between the Te Humenga and Ngawi sites (see Fig. 4.11 c) provides a strandline elevation of $198.3 \pm 8.3 \mathrm{~m}$ and a corresponding uplift rate of $1.6 \pm 0.1 \mathrm{~mm} / \mathrm{yr}$.
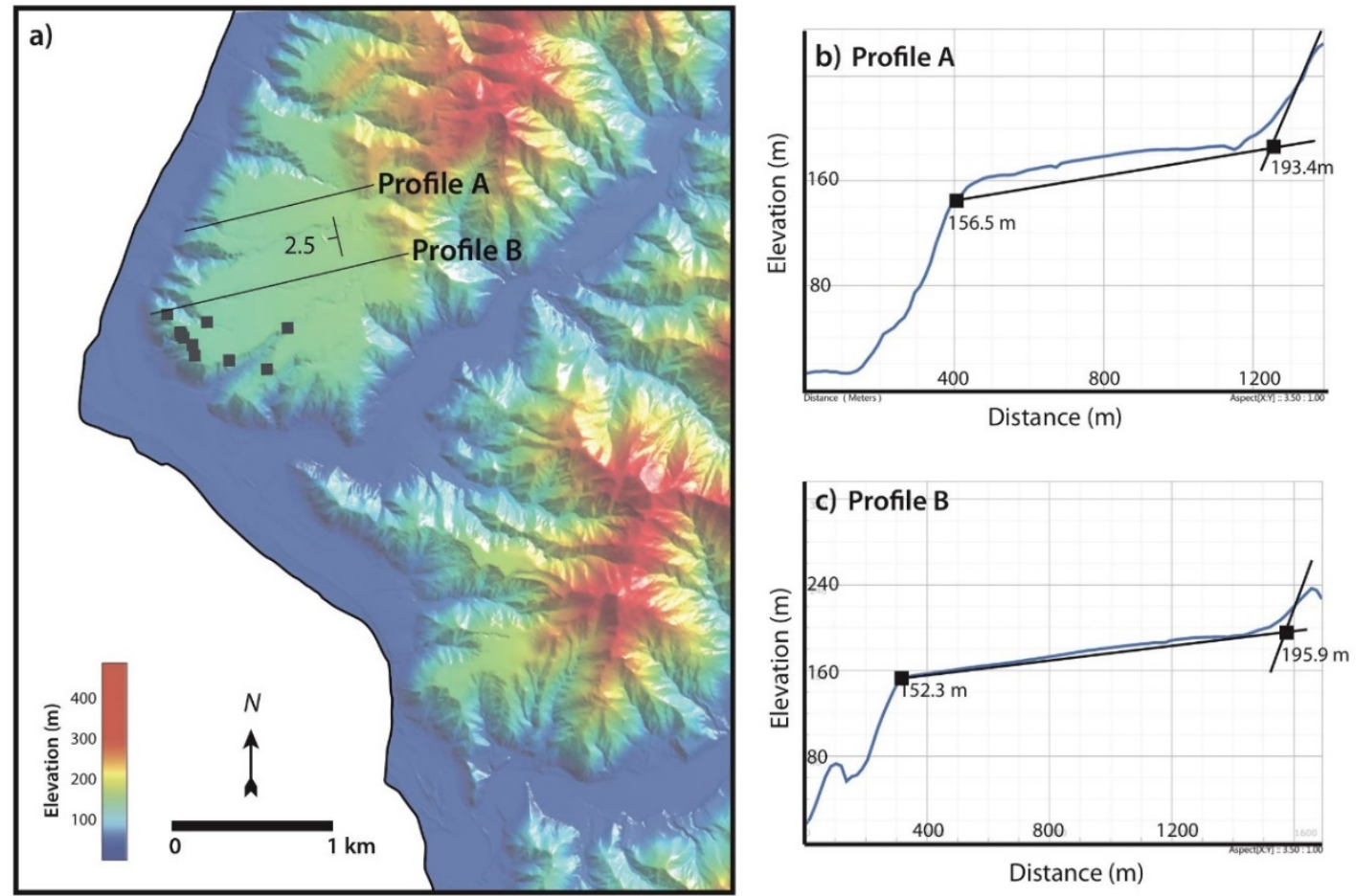

Figure 4.10. a) Pleistocene marine terraces at Te Humenga, showing strandline elevation profiles, on digital terrace data backdrop (courtesy GWRC; b) Profile A; c) Profile B; d) Profile C.

\subsection{Discussion}

\subsubsection{Uplift Rates of the South Coast Terraces}

Uplift rates along the south coast of the North Island of New Zealand, between Cape Palliser and Wharekauhau, gradually decrease from east to west (Fig. 4.12), despite the fact that uplift rates have been determined from different-aged terraces along this coast.

The uplift rate calculated from the MIS 5e terrace near Cape Palliser, the eastern-most preserved terrace on the south coast of the North Island, is $1.7 \pm 0.1 \mathrm{~mm} / \mathrm{yr}$, decreasing slightly to $1.5 \pm 0.1 \mathrm{~mm} / \mathrm{yr}$ at Te Humenga. Here, the MIS 5e terrace is tilted by $2.5-2.9^{\circ}$ towards the west. At Washpool, the uplift rate determined from the younger MIS 5a terrace preserved locally is $1.3 \pm 0.1 \mathrm{~mm} / \mathrm{yr}$. Moreover, the MIS 5a terrace at Washpool is also tilted less than 

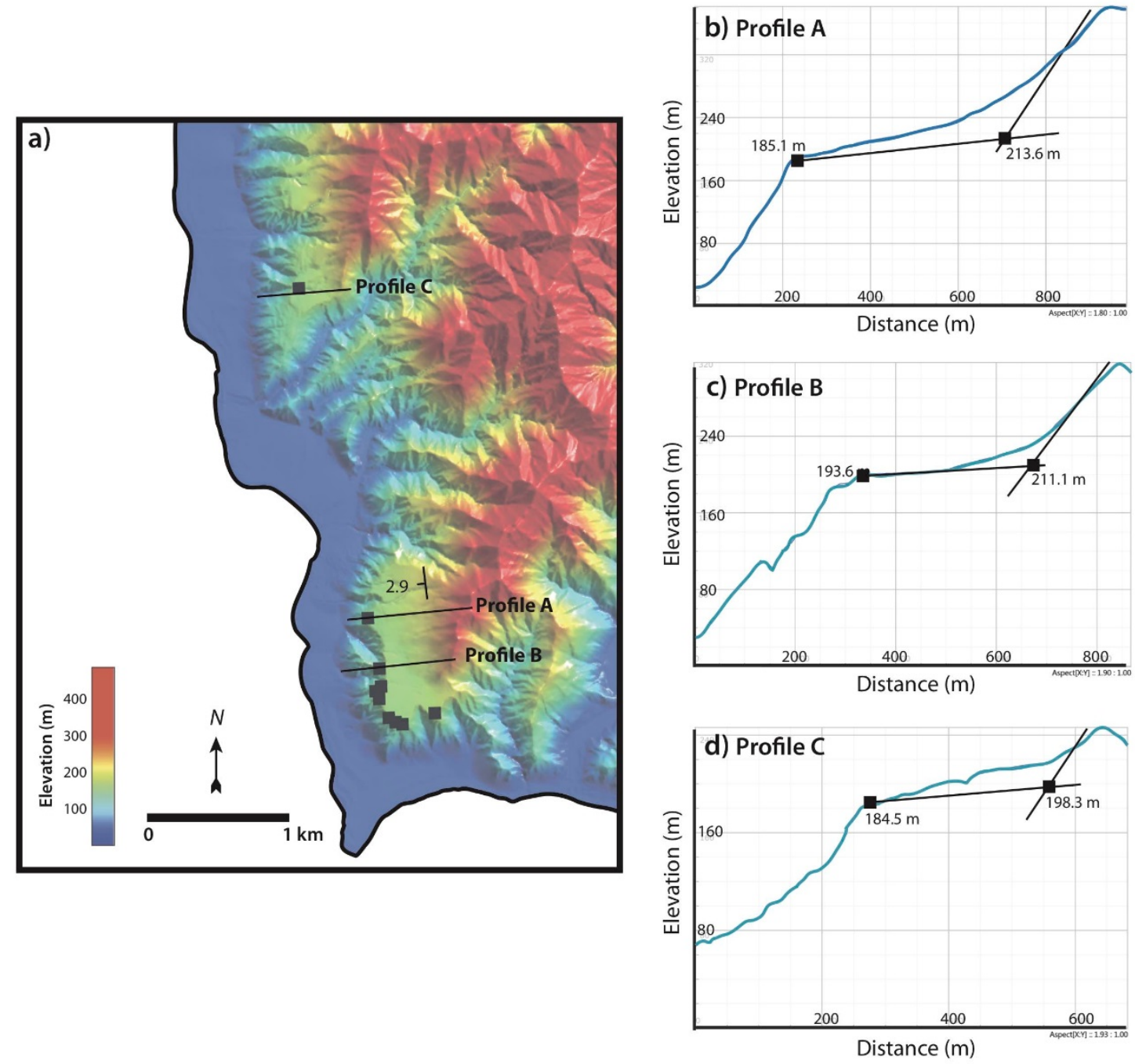

Figure 4.11. a) Pleistocene marine terraces at Ngawi, near Cape Palliser, showing strandline elevation profiles, on digital terrace data backdrop (courtesy GWRC; b) Profile A; c) Profile B; d) Profile C.

the older terraces on this coast, with a dip of $1.5^{\circ}$ towards the west. This is consistent with what we would expect - that the older terraces, being exposed to tectonic deformation over a longer period of time, are more tilted than the younger terraces. A comparison of the degree of tilting of these two different-aged shore platforms over time provides us with a tilt rate. The tilt rate calculated from the MIS 5e shore platform where it is preserved between Te Humenga and Ngawi, and that calculated from the nearby MIS 5a shore platform at Washpool/Whatarangi both yield a tilt rate of $\sim 0.02^{\circ} / \mathrm{ka}$. 
Table 4B. Strandline Elevations and Uplift Rates

\begin{tabular}{|c|c|c|c|c|c|c|}
\hline \multirow[t]{2}{*}{ Location } & \multirow{2}{*}{$\begin{array}{c}\text { Terrace } \\
\text { Age } \\
\text { (MIS) }\end{array}$} & \multirow{2}{*}{$\begin{array}{c}\text { Terrace } \\
\text { Age } \\
\text { (MIS Peak) } \\
\text { (ka) }\end{array}$} & \multicolumn{2}{|c|}{ Elevation $(\mathrm{m})$} & \multirow[t]{2}{*}{ Uplift (m) } & \multirow{2}{*}{$\begin{array}{c}\text { Uplift Rate } \\
\text { (mm/yr) }\end{array}$} \\
\hline & & & Strandline & Shore Platform & & \\
\hline Tongue Point & $\begin{array}{c}5 a \\
(5 c)\end{array}$ & $\begin{array}{l}82 \\
(96)\end{array}$ & & $\begin{array}{c}16.0 \pm 3.0(\mathrm{U}) \\
7.0 \pm 3.0(\mathrm{D}) \\
16.0 \pm 3.0(\mathrm{U}) \\
7.0 \pm 3.0(\mathrm{D})\end{array}$ & $\begin{array}{l}26.0 \pm 9.0 \\
17.0 \pm 9.0 \\
27.0 \pm 10.0 \\
18.0 \pm 10.0\end{array}$ & $\begin{array}{l}0.3 \pm 0.1(U) \\
0.2 \pm 0.1(D) \\
0.3 \pm 0.1(U) \\
0.2 \pm 0.1(D)\end{array}$ \\
\hline & $5 e$ & 123 & & $\begin{array}{l}75.0 \pm 3.0(U) \\
27.0 \pm 3.0(D)\end{array}$ & $\begin{array}{l}67.7 \pm 4.8 \\
19.7 \pm 4.8\end{array}$ & $\begin{array}{l}0.6 \pm 0.1(U) \\
0.2 \pm 0.1(D)\end{array}$ \\
\hline & $7 a$ & 196 & & $82.7 \pm 3.0(\mathrm{D})$ & $94.7 \pm 6.0$ & $0.5 \pm 0.1(D)$ \\
\hline Baring Head & $5 a$ & 82 & & $120.5 \pm 3.0$ & $130.5 \pm 9.0$ & $1.6 \pm 0.1 \#$ \\
\hline & $5 a$ & 82 & $89.8 \pm 4.7$ & & $99.8 \pm 10.7$ & $1.2 \pm 0.1$ \\
\hline “ & $5 e$ & 123 & & $95.8 \pm 3.0$ & $88.5 \pm 4.7$ & $0.7 \pm 0.1$ \\
\hline “ & $7 a$ & 196 & & $173.6 \pm 3.0$ & $185.6 \pm 6.0$ & $1.0 \pm 0.1$ \\
\hline Wharekauhau & $7 a$ & 196 & $17.9 \pm 3.0$ & & $29.9 \pm 6.0$ & $0.2 \pm 0.1$ \\
\hline Lake Ferry & $5 c$ & 96 & $61.1 \pm 0.1$ & & $72.1 \pm 7.1$ & $0.8 \pm 0.1$ \\
\hline Te Kopi & $5 c$ & 96 & $94.9 \pm 0.4$ & & $105.9 \pm 7.4$ & $1.0 \pm 0.1$ \\
\hline Washpool & $5 a$ & 82 & $92.1 \pm 0.7$ & & $102.1 \pm 6.7$ & $1.3 \pm 0.1$ \\
\hline & $\begin{array}{c}5 e \\
(5 c)\end{array}$ & $\begin{array}{l}125 \\
(96)\end{array}$ & & $114.0 \pm 3.0$ & $\begin{array}{c}106.7 \pm 4.8 \\
125.0 \pm 10.0\end{array}$ & $\begin{array}{l}0.9 \pm 0.1 \\
1.3 \pm 0.1\end{array}$ \\
\hline Te Humenga & $5 e$ & 123 & $195.9 \pm 2.0$ & & $188.6 \pm 3.8$ & $1.5 \pm 0.1$ \\
\hline Ngawi & $5 e$ & 123 & $213.6 \pm 8.3$ & & $206.3 \pm 10.0$ & $1.7 \pm 0.1$ \\
\hline
\end{tabular}

Where shown in Italics, uplift rate has been calculated from a shore platform exposure, and so is a minimum value for that location.

'Uplift' values are Strandline or shore platform elevations corrected for sea level at the time of shore platform development:

MIS 5a: -4 to $-16 \mathrm{~m}$ (Creveling et al., 2017);

MIS 5c: - -4 to -18 m (Creveling et al., 2017);

MIS 5e: +5.5 to +9 m (Dutton \& Lambeck, 2012);

MIS 7a: -9 to -15 m (Bard et al., 2002; Siddall et al., 2007; Grant et al., 2012; 2014).

\# Calculated from the easternmost extent of the Baring Head MIS 5 a terrace, closest to the Wairarapa

Fault.

(U) and (D) denote the upthrown and downthrown sides of the Ohariu Fault, respectively. 
Uplift determined from the MIS 5c terrace preserved along the coast between Lake Ferry and Te Kopi yields rates of $1.0 \pm 0.1 \mathrm{~mm} / \mathrm{yr}$ at the eastern extent of this area. At the western extent of this terrace, near Lake Ferry, the uplift rate is $0.8 \pm 0.1 \mathrm{~mm} / \mathrm{yr}$. Despite being older than the MIS 5a terrace at Washpool, this terrace is only tilted by $0.6^{\circ}-0.7^{\circ}$ to the west. This change in dip and dip direction, of $156 / 0.7 \mathrm{~W}$ west of the fault and $030 / 0.6 \mathrm{~W}$ to the east, likely reflects the local deformation of this terrace by the Pirinoa Fault.

Further to the west, at Wharekauhau, uplift determined from the MIS 7a terrace there yields rates of $0.2 \pm 0.1 \mathrm{~mm} / \mathrm{yr}$. Moreover, despite this terrace being the oldest along this length of coast, it is tilted the least, with a calculated dip of only $0.2^{\circ}$ towards the southwest. With such a shallow dip in a direction towards the coast, it may be that this shore platform still maintains much of its original, formative gradient, despite being located near to the Wairarapa and Wharekauhau faults.

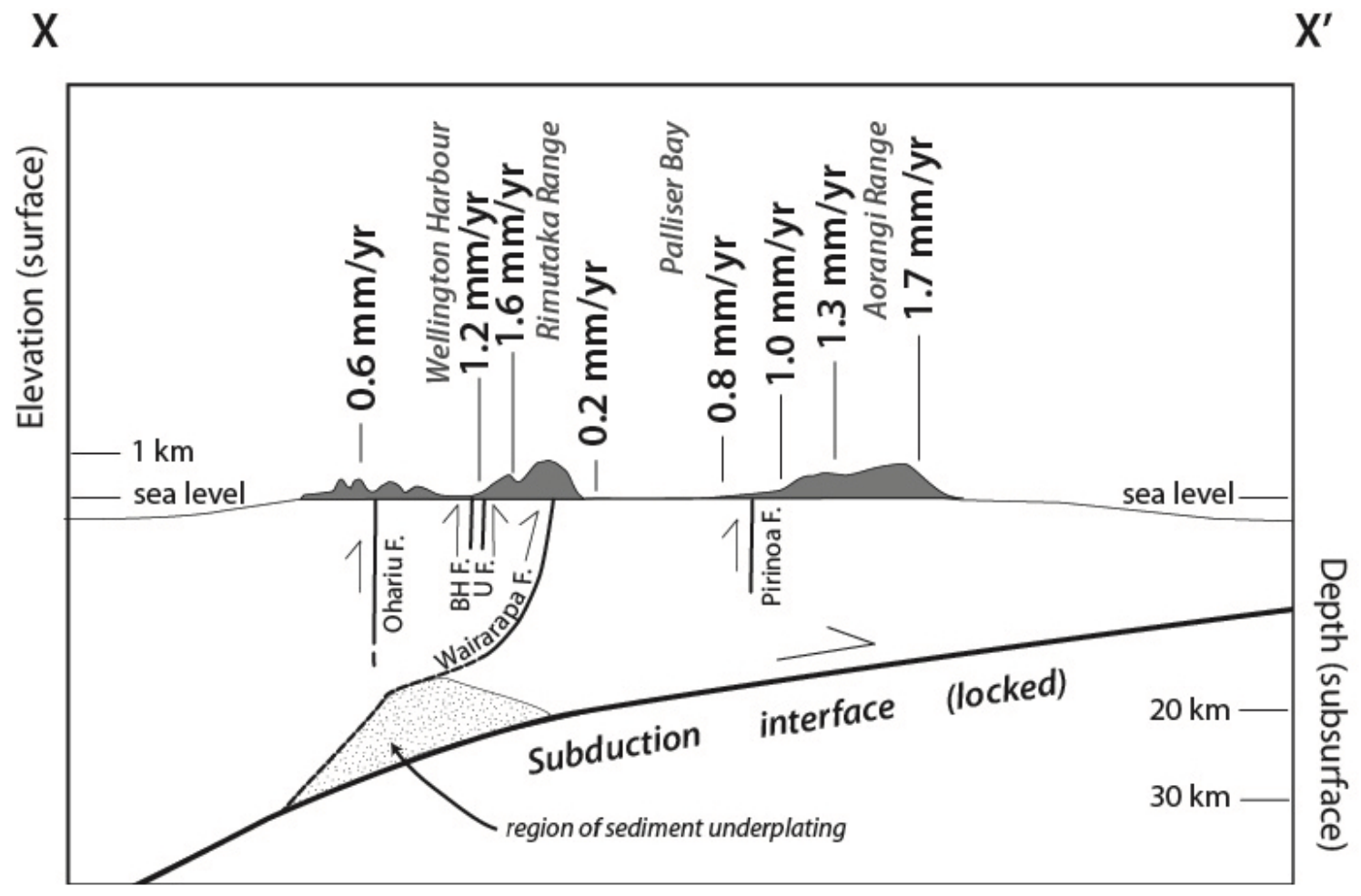

Figure 4.12. Schematic cross section $X-X^{\prime}$ (see Fig. 1.1, Fig. 1.3 for location of profile) across southern North Island, showing representative topography (exaggerated), uplift rates and locations of faults observed to offset the Pleistocene marine terraces; 'BH F.' is Baring Head Fault, 'U F.' is un-named fault at Baring Head. Figure modified after Little et al. (2009) and updated using data from Begg \& Johnston (2000), Henrys et al. (2013) and Williams et al. (2013). Subsurface Wairarapa Fault location and region of sediment underplating from Henrys et al. (2013). 
Although my uplift calculations yield results similar to earlier estimates by Ghani $(1974 ; 1978)$ for Cape Palliser, and are within error of his estimates at Lake Ferry, my uplift evaluation for Wharekauhau is much less than the $1.0 \mathrm{~mm} / \mathrm{yr}$ reported by Ghani $(1974 ; 1978)$. This is likely due to the additional three terraces Ghani $(1974 ; 1978)$ allocated to this site. As explained in Chapter 3, I infer that what Ghani $(1974 ; 1978)$ interpreted to be additional older terrace treads are instead a series of fan deposits that give the appearance of terrace treads at different elevations.

Further to the west, at Baring Head, the uplift rates calculated from three different-aged terraces are higher than the uplift rate quantified at Wharekauhau. This is not surprising given that this area experiences uplifted due to rupture on the Wairarapa Fault, as evident in the Holocene marine benches preserved at Turakirae Head (McSaveney et al., 2006). The uplift rate calculated from the easternmost shore platform elevation of the MIS 5a terrace, the closest Pleistocene shore platform exposure to the Wairarapa Fault, yields a minimum uplift rate of $1.6 \pm 0.1 \mathrm{~mm} / \mathrm{yr}$. This is slightly higher than the Holocene uplift rate of $\sim 1.3 \mathrm{~mm} / \mathrm{yr}$, estimated for this location, near the mouth of the Orongorongo River, by Begg \& McSaveney (2005).

Two faults offset the Pleistocene shore platforms at Baring Head. A yet-to-be-named fault offsets the MIS 5a terrace near the Orongorongo River mouth. The difference in uplift rate observed across this structure suggests it has a vertical slip rate of $\sim 0.1 \mathrm{~mm} / \mathrm{yr}$ uplifted to the east. In a similar fashion, a vertical slip rate of $\sim 0.2 \mathrm{~mm} / \mathrm{yr}$ uplifted to the west was calculated for the Baring Head Fault for the last $82 \mathrm{ka}$.

The uplift rates calculated from the MIS 5a, MIS 5e and MIS 7a shore platforms where they are preserved between the Baring Head and un-named faults, are inconsistent across the different time periods, yielding values of $1.2 \pm 0.1 \mathrm{~mm} / \mathrm{yr}$ since $82 \mathrm{ka}, 0.7 \pm 0.1 \mathrm{~mm} / \mathrm{yr}$ since $123 \mathrm{ka}$, and $1.0 \pm 0.1 \mathrm{~mm} / \mathrm{yr}$ since $196 \mathrm{ka}$. There are a number of scenarios that could explain this variability.

Assuming that the OSL-derived and inferred shore platform ages are correct, this variable uplift rate could reflect alternating periods of activity and quiescence on the nearby Wairarapa Fault, much like that reported on the Wellington Fault (Robinson et al., 2011; Chapter 2 and Ninis et $a l ., 2013)$. If this is the case, then the uplift rates would suggest that the Wairarapa fault has been more active in the last $82 \mathrm{ka}$, than between 82 and $123 \mathrm{ka}$. Alternatively, the time-varying uplift rate could reflect a complex interaction between overall uplift at the Baring Head site due to slip on the Wairarapa Fault, and localised down-throwing as a result of slip on the two other faults that offset the terraces at this site, including the Baring Head Fault. Another possible 
competing process effecting vertical deformation at this site is permanent coseismic subsidence from megathrust earthquakes; the Baring Head site is modelled to experience coseismic subsidence from subduction interface earthquakes (Clark et al., 2015). Moreover, as described in Chapter 1, findings from the recent Seismic Array Hikurangi Experiment (SAHKE) (Henrys et al., 2013) identified sediment underplating at the subduction interface beneath this region which has been inferred to drive local uplift of the ranges above.

The next scenario is that ages assigned to one or more of the marine terraces are incorrect. A sample collected from beach deposits, $2.5 \mathrm{~m}$ above the shore platform of the main terrace at Baring Head yielded an OSL age of $55.5 \pm 8.7 \mathrm{ka}$, which correlates with the MIS 3/MIS 4 boundary. The original interpretation, as presented in Chapter 3, was that this OSL age underestimated the true age of the shore platform, and that the shore platform was in fact MIS 5a in age. Support for this interpretation is provided from the MIS 5a terrace preserved at Washpool/Whatarangi, where a similar OSL age $(56.1 \pm 2.3 \mathrm{ka})$ was obtained from marine coverbeds at a similar distance above the shore platform, while an older age of $68.8 \pm 8.8 \mathrm{ka}$, consistent with MIS 5a, was obtained just above the shore platform. If, however, the inferred MIS 5a terrace at Baring Head is in fact MIS 3 in age, then the uplift rate would be even higher, in the order of $\sim 2.7 \mathrm{~mm} / \mathrm{yr}$ for the last $\sim 55 \mathrm{ka}$. Another possibility is that the terrace at Baring Head is MIS $5 \mathrm{c}$ in age. This would yield an uplift rate in the order of $\sim 1.0 \mathrm{~mm} / \mathrm{yr}$, which is somewhat more consistent with the uplift rates determined from the inferred MIS 5e terrace and OSL-constrained MIS 7a terrace. Ota et al. (1991) suggested that this main terrace at Baring Head correlates to MIS 5e, based mainly on the fact that MIS 5e terraces are especially widespread and well-preserved world-wide. If the main terrace at Baring Head is indeed MIS $5 \mathrm{e}$ in age, then this would yield an uplift rate of $\sim 0.7 \mathrm{~mm} / \mathrm{yr}$. However, this interpretation has consequences for all of the older terraces in the sequence; if the main terrace is MIS 5e in age, then it follows that all of the higher marine terraces at Baring Head are older than our original assigned ages.

In summary, the marine terraces at Baring Head warrant further dating. In addition to coseismic uplift due to movement on the Wairarapa Fault, this region experiences localised vertical deformation as a result of the two faults that cross here. In addition, this site may experience coseismic subsidence during megathrust earthquakes, as suggested by Clark et al. (2015), as well as uplift associated to the sediment underplating beneath this region (Walcott, 1984; Henrys et al., 2013). The fact that this site has the most preserved terraces of any of the sites on the south coast could reveal much about uplift rates, and whether or not they have been variable, since the Pleistocene. 
At our westernmost field site, at Tongue Point, the calculated uplift rates for the MIS 5e terrace preserved on the western, upthrown side of the Ohariu Fault is of $0.6 \pm 0.1 \mathrm{~mm} / \mathrm{yr}$. This rate is higher than that calculated from the younger terrace preserved beneath it, irrespective of whether the younger terrace formed during MIS $5 \mathrm{a}$ or $5 \mathrm{c}$, both of which yield an uplift rate of $0.3 \pm 0.1 \mathrm{~mm} / \mathrm{yr}$. This suggests that uplift at this site, may also not have been steady during the last $\sim 123 \mathrm{ka}$. This could reflect alternating periods of activity and then relative quiescence on the Ohariu Fault, much like the behaviour observed on the Wellington Fault (Chapter 2; Ninis et al., 2013) and possibly the Wairarapa Fault. Alternatively, as with the Baring Head site, the region could experience a more complex interaction between vertical deformation from the Ohariu Fault, uplift due to sediment underplating (Walcott, 1984; Henrys et al., 2013) and subsidence due to subduction interface events (Clark et al., 2015).

The large uncertainties associated with the uplift rates calculated from the MIS 5e terrace on the eastern, downthrown side of the Ohariu Fault at Tongue Point does not allow for any meaningful interpretations to be made about uplift and whether or not it has varied over the last $\sim 196 \mathrm{ka}$. The shore platform orientation for the MIS 5e terrace on the downthrown side of the fault likely over-estimates the true dip of the shore platform. As a result, the reconstructed strandline elevation and corresponding uplift rate of $\sim 0.6 \mathrm{~mm} / \mathrm{yr}$ are also likely to be overestimates. Using a shore platform elevation yields a minimum uplift rate for this side of the fault of $0.2 \pm 0.1 \mathrm{~mm} / \mathrm{yr}$. The uplift rates calculated from the youngest Pleistocene terrace on the downthrown side of the fault are within error of the wide range calculated from MIS 5e, irrespective of whether the younger terrace is MIS $5 \mathrm{a}$ or $5 \mathrm{c}$ (both yield $0.2 \pm 0.1 \mathrm{~mm} / \mathrm{yr}$ ) in age. Likewise, the minimum uplift rate calculated from the MIS 7a terrace on this same side of the fault, of $0.5 \pm 0.1 \mathrm{~mm} / \mathrm{yr}$, is also within error.

\subsubsection{Uplift Patterns and Implications for Southern Hikurangi Subduction Margin Processes}

\subsubsection{Uplift across the southern Hikurangi forearc}

The overall pattern of westward tilting and corresponding decreasing uplift of the preserved marine terraces along the coast in the forearc, between Cape Palliser ( $\sim 40 \mathrm{~km}$ from the trough) and Wharekauhau ( $\sim 70 \mathrm{~km}$ from the trough), suggests that the process responsible for their deformation loses influence from east to west. This suggests the source of the uplift and tilting of the marine terraces along the coast of Palliser Bay may be located to the east and offshore. I here consider the scenarios of rupture of an offshore, upper plate fault, and rupture of the subduction interface. 
The steady decrease in both uplift and tilting in the Palliser Bay region is observed across a distance of $\sim 30 \mathrm{~km}$. Based on this distance alone, it is unlikely that an upper plate fault could be the source of this uplift. Nonetheless, in the interest of being thorough, I discuss upper plate faults offshore of the east coast of the southern North Island as possible sources of uplifted of the Pleistocene marine terraces of the forearc.

There have been two major fault structures identified in this region, the Palliser-Kaiwhata and Boo Boo faults (Barnes \& Mercier de Lepinay, 1997; Barnes et al., 1998; Barnes \& Audru, 1999) (see Fig. 1.3). The Boo Boo Fault is pure dextral strike slip, so is unlikely to be the cause of uplift. The Palliser-Kaiwhata Fault is a reverse fault and, as mentioned in the Introduction chapter, is thought to be the cause of uplift of terraces on the east coast of the North Island (Berryman et al., 2011; Litchfield \& Clark, 2015). A dislocation model of uplift associated with oblique slip on the western part of the Palliser-Kaiwhata Fault, dipping $40^{\circ}$ to the west, and rupturing to the subduction interface (L. Wallace, pers. comm., 2008) suggests that this structure would produce uplift of $<20 \mathrm{~km}$ inland of the east coast, a shorter distance than the uplift pattern observed on the marine terraces across Palliser Bay.

The uplift pattern of the Palliser Bay Pleistocene marine terraces, in the forearc of the southern Hikurangi Margin, does however mirror results of Clark et al. (2015), whose modelling of coseismic deformation from a southern Hikurangi subduction interface earthquake estimates that maximum uplift closest to the trough of $\sim 1 \mathrm{~m}$ at Cape Palliser, decreasing to $<0.5 \mathrm{~m}$ at Wharekauhau, diminishing to zero uplift near Turakirae Head (see Fig. 4.3). However, net tectonic uplift over the last $200 \mathrm{ka}$, as observed along the south coast and reported in this study, cannot directly be compared with the vertical deformation results predicted by Clark et al. (2015), because their model estimates coseismic deformation of a single megathrust event, whereas net vertical uplift since $\sim 200 \mathrm{ka}$ ago would also include the effects of post seismic relaxation, interseismic strain accumulation, and vertical deformation from upper plate faults. The latter is especially true at Wharekauhau, which would not only experience coseismic uplift from a megathrust event, as estimated by Clark et al. (2015) but would also experience deformation from the nearby Wairarapa and Wharekauhau faults. Nonetheless, the fact that the general pattern of uplift observed across the Hikurangi forearc mirrors the coseismic vertical deformation results of Clark et al. (2015) warrants consideration; it suggests that, if some amount of coseismic uplift from megathrust earthquakes is permanently preserved in the topography of the southern North Island, then megathrust earthquakes at the southern Hikurangi margin could be a plausible candidate for the observed deformation of Pleistocene marine terraces between Cape Palliser and Wharekauhau. 
Although the similarities between the uplift patterns of the Pleistocene terraces in the Hikurangi forearc and those estimated by coseismic subduction earthquakes by Clark et al. (2015), suggest that it is possible that megathrust earthquakes are a candidate for the source of permanent uplift across the southern Hikurangi margin, other subduction processes also need to be considered. Finite element modelling by Lichfield et al., (2007), which included uplift rates determined from marine terraces and incision rates measured from fluvial terraces across the entire length of the eastern North Island, attributed broad-wavelength uplift patterns along the length of the east coast of the North Island to the subduction of an overthickened and buoyant Hikurangi plateau. The uplift estimated to be the result of this subduction is $\sim 1 \mathrm{~mm} / \mathrm{yr}$. This would imply that across the southern North Island, subduction of a buoyant slab is responsible for only part of the uplift; some other factor contributes to the remainder of uplift across this region.

In summary, upper plate faulting is unlikely to be the main source of uplift and tilting of the Pleistocene marine terraces along the Palliser Bay coast. Moreover, when compared to results from Lichfield et al. (2007) and Clark et al. (2015) the long-wavelength ( $\sim 30 \mathrm{~km})$ pattern of uplift evident in the forearc region of the margin indicates that deep-seated processes, possibly a combination of subduction of the buoyant Hikurangi Plateau and a component of permanent coseismic uplift from megathrust earthquakes, are responsible for the vertical deformation recorded there.

\subsubsection{Uplift across the southern Hikurangi Axial Ranges}

West of Palliser Bay, in the Axial Ranges at a distance of $\sim 70-100 \mathrm{~km}$ from the Hikurangi Trough, the abrupt increases in uplift rate at Baring Head, on the upfaulted side of the Wairarapa Fault, and the changes in uplift rates across the Ohariu Fault at Tongue Point, suggest that dip slip motion on the major, active, upper plate faults contributes locally to tectonic uplift across this region.

The uplift rates calculated from the Pleistocene marine terraces preserved on either side of the Wairarapa Fault, at Wharekauhau and Baring Head, allow for an estimate of vertical slip on this structure. Uplift quantified from the easternmost preserved terrace at Baring Head (i.e. closest to the Wairarapa Fault), when compared to uplift at Wharekauhau, on the eastern, downthrown side of the fault, indicates that vertical slip on the Wairarapa fault is $\sim 1.4 \mathrm{~mm} / \mathrm{yr}$. This is a minimum value; uplift quantified from sites closer to the fault would yield an even higher uplift rate.

Father west, the dip slip rates of faults that offset the Pleistocene marine terraces are smaller. The vertical slip on the Baring Head Fault since $\sim 82 \mathrm{ka}$ has been calculated as $\sim 0.2 \mathrm{~mm} / \mathrm{yr}$, 
uplifted to the west. Vertical slip of an additional, un-named fault that offsets the Pleistocene marine terraces at Baring Head is $\sim 0.1 \mathrm{~mm} / \mathrm{yr}$, uplifted to the east. In comparison, the uplift rate at Baring Head (calculated from the down-thrown area between these two faults) is $1.2 \pm$ $0.1 \mathrm{~mm} / \mathrm{yr}$. The data suggest that these two faults that offset the terraces at Baring Head do not contribute very much to overall uplift at this site.

At Tongue Point, vertical slip on the Ohariu Fault is $\sim 0.4 \mathrm{~mm} / \mathrm{yr}$, uplifted to the west. When comparing uplift rates calculated from either side of the fault, of $0.6 \pm 0.1 \mathrm{~mm} / \mathrm{yr}$ from the upthrown side $0.2 \pm 0.1 \mathrm{~mm} / \mathrm{yr}$ on the down-thrown side, it is evident that at Tongue Point, movement on the Ohariu Fault plays a major role in local uplift.

As the downthrown sides of the faults at both Baring Head and Tongue Point have been elevated relative to sea level, some other process, or processes, must be contributing to the broader uplift across the Axial Ranges. As in the forearc region, the subduction of the buoyant Hikurangi plateau may also be causing uplift in the Axial Ranges. However, there is a sudden increase in the dip of the subduction interface, from $<5^{\circ}$ at shallow depths (within $\sim 15 \mathrm{~km}$ of the surface) to $>15^{\circ}$ at greater depths, and a region of sediment underplating (Henrys et al., 2013), approximately beneath Wharekauhau and the Wairarapa Fault. I propose that west of this region, uplift influenced by subduction of a buoyant slab diminishes across the Axial Ranges. Instead, I infer that sediment underplating, which is inferred to be responsible for the higher uplift rates in the Axial Ranges of the central and northern Hikurangi margin (Lichfield et al., 2007) also contributes to uplift in the Axial Ranges at the southern Hikurangi margin.

\subsection{Conclusion}

The age of marine terraces preserved along the south coast of the North Island of New Zealand, and their corresponding strandline elevations, have been used to calculate uplift rates across the southern Hikurangi margin during the Pleistocene. In general, uplift rates are highest closest to the Hikurangi Trough, with $1.7 \pm 0.1 \mathrm{~mm} / \mathrm{yr}$ observed at the easternmost preserved terraces, near Cape Palliser, $\sim 40 \mathrm{~km}$ from the trough. Uplift rates decreases steadily along the Palliser Bay coast to $0.2 \pm 0.1 \mathrm{~mm} / \mathrm{yr}$ at Wharekauhau, $\sim 70 \mathrm{~km}$ from the trough. The long-wavelength pattern of uplift evident on the Palliser Bay coast indicates that deep-seated subduction processes, most likely a combination of subduction of the buoyant Hikurangi Plateau and a component of inelastic coseismic uplift from megathrust earthquakes, are probable candidates for the vertical deformation in this forearc region. Further from the Hikurangi Trough, at distances $>70 \mathrm{~km}$, uplift rates increase again at Baring Head, on the upfaulted side of the Wairarapa Fault, to between $0.7 \pm 0.1$ and $1.6 \pm 0.1 \mathrm{~mm} / \mathrm{yr}$. At Tongue Point, west of 
Wellington, I have calculated uplift rates of $0.2 \pm 0.1 \mathrm{~mm} / \mathrm{yr}$ and $0.6 \pm 0.1 \mathrm{~mm} / \mathrm{yr}$ for the MIS 5e shore platform preserved there, on the downthrown and upthrown sides of the Ohariu Fault, respectively. Here, in the Axial Ranges, the abrupt increases in uplift rates across these upper plate faults suggest that, in addition to sediment underplating, movement on these structures is a major contributor to tectonic uplift across this region. 


\section{References}

Bard, E., Antonioli, F. and Silenzi, S., 2002. Sea-level during the penultimate interglacial period based on a submerged stalagmite from Argentarola Cave (Italy). Earth and Planetary Science Letters, 196(3), pp.135-146.

Barnes, P. M., and Mercier de Lepinay, B., 1997. Rates and mechanics of rapid frontal accretion along the very obliquely convergent southern Hikurangi margin, New Zealand, J. Geophys. Res. 102, B11, 24931-24952.

Barnes, P. M., Mercier de Lepinay, B., Collot, J-Y., Delteil, J. and Audru, J-C., 1998. Strain partitioning in the transition area between oblique subduction and continental collision, Hikurangi margin, New Zealand, Tectonics. 17 534-557.

Barnes, P. M., and Audru, J. C., 1999. Quaternary faulting in the offshore Flaxbourne and Wairarapa basins, southern Cook Strait, New Zealand. New Zealand Journal of Geology and Geophysics, 42(3): 349-367.

Beavan, J and Darby, D., 2005. Fault slip in the 1855 Wairarapa Earthquake, based on new and reassessed vertical motion observations: did slip occur on the subduction interface? In: The 1855 Wairarapa Earthquake Symposium — Proceedings Volume. Greater Wellington Regional Council Publication Number: GW/RINV-T-05/205, ISBN: 0-909016-87-9, September 2005.

Begg, J.G. and Johnston, M.R., 2000. Geology of the Wellington area. 1: 250000 Geological map 10. Institute of Geological and Nuclear Sciences, Lower Hutt, New Zealand.

Begg, J and McSaveney, M.J., 2005. Wairarapa Fault Rupture - Vertical deformation in 1855 and a history of similar events from Turakirae Head. In: The 1855 Wairarapa Earthquake Symposium - Proceedings Volume. Greater Wellington Regional Council Publication Number: GW/RINV-T-05/205, ISBN: 0-909016-87-9, September 2005.

Berryman, K., 1993 (a). Age, height, and deformation of Holocene marine terraces at Mahia Peninsula, Hikurangi subduction margin, New Zealand. Tectonics, 12(6), pp.1347-1364.

Berryman, K.R., 1993 (b). Distribution, age, and deformation of late Pleistocene marine terraces at Mahia Peninsula, Hikurangi subduction margin, New Zealand. Tectonics, 12(6), pp.13651379 .

Berryman, K., Ota, Y., Miyauchi, T., Hull, A., Clark, K., Ishibashi, K., Iso, N. and Litchfield, N., 2011. Holocene paleoseismic history of upper-plate faults in the southern Hikurangi subduction margin, New Zealand, deduced from marine terrace records. Bulletin of the Seismological Society of America, 101(5), pp.2064-2087.

Bradley, W. C., and G. B. Griggs. "Form, genesis, and deformation of central California wave-cut platforms." Geological Society of America Bulletin 87, no. 3 (1976): 433-449.

Briggs, R.W., Sieh, K., Meltzner, A.J., Natawidjaja, D., Galetzka, J., Suwargadi, B., Hsu, Y.J., Simons, M., Hananto, N., Suprihanto, I. and Prayudi, D., 2006. Deformation and slip along the Sunda megathrust in the great 2005 Nias-Simeulue earthquake. Science, 311(5769), pp.1897-1901.

Carver, G.A., Jayko, A.S., Valentine, D.W. and Li, W.H., 1994. Coastal uplift associated with the 1992 Cape Mendocino earthquake, northern California. Geology, 22(3), pp.195-198. 
Chappell, J., 1974. Geology of coral terraces, Huon Peninsula, New Guinea: a study of Quaternary tectonic movements and sea-level changes. Geological Society of America Bulletin, 85(4), pp.553-570.

Chappell, J. and Shackleton, N., 1986. Oxygen isotopes and sea level. Nature, 324(6093), pp.137-140.

Chappell, J., Omura, A., Esat, T., McCulloch, M., Pandolfi, J., Ota, Y. and Pillans, B., 1996. Reconciliaion of late Quaternary sea levels derived from coral terraces at Huon Peninsula with deep sea oxygen isotope records. Earth and Planetary Science Letters, 141(1-4), pp.227236.

Chappell, J., 2002. Sea level changes forced ice breakouts in the Last Glacial cycle: new results from coral terraces. Quaternary Science Reviews, 21(10), pp.1229-1240.

Clark, K.J., Hayward, B.W., Cochran, U.A., Grenfell, H.R., Hemphill-Haley, E., Mildenhall, D.C., Hemphill-Haley, M.A. and Wallace, L.M., 2011. Investigating subduction earthquake geology along the southern Hikurangi margin using palaeoenvironmental histories of intertidal inlets. New Zealand Journal of Geology and Geophysics, 54(3), pp.255-271.

Clark, K.J., Hayward, B.W., Cochran, U.A., Wallace, L.M., Power, W.L. and Sabaa, A.T., 2015. Evidence for past subduction earthquakes at a plate boundary with widespread upper plate faulting: Southern Hikurangi margin, New Zealand. Bulletin of the Seismological Society of America.

Clark, K. J., Nissen, E. K., Howarth, J. D., Hamling, I.J., Mountjoy, J. J., Ries, W. F., Jones, K., Goldstien, S., Cochran, U. A., Villamor, P., Hreinsdóttir, S., Litchfield, N. J., Mueller, C., Berryman, K. R., and Strong, D. T., 2017. Highly variable coastal deformation in the 2016 MW7.8 Kaikōura earthquake reflects rupture complexity along a transpressional plate boundary. Earth and Planetary Science Letters, in press.

Clement, A.J., Whitehouse, P.L. and Sloss, C.R., 2016. An examination of spatial variability in the timing and magnitude of Holocene relative sea-level changes in the New Zealand archipelago. Quaternary Science Reviews, 131, pp.73-101.

Cochran, U., Hannah, M., Harper, M., Van Dissen, R., Berryman, K. and Begg, J., 2007. Detection of large, Holocene earthquakes using diatom analysis of coastal sedimentary sequences, Wellington, New Zealand. Quaternary Science Reviews, 26(7), pp.1129-1147.

Creveling, J.R., Mitrovica, J.X., Clark, P.U., Waelbroeck, C. and Pico, T., 2017. Predicted bounds on peak global mean sea level during marine isotope stages $5 \mathrm{a}$ and $5 \mathrm{c}$. Quaternary Science Reviews, 163, pp.193-208.

Cutler, K.B., Edwards, R.L., Taylor, F.W., Cheng, H., Adkins, J., Gallup, C.D., Cutler, P.M., Burr, G.S. and Bloom, A.L., 2003. Rapid sea-level fall and deep-ocean temperature change since the last interglacial period. Earth and Planetary Science Letters, 206(3), pp.253-271.

Downes, G.L., 2005. The 1855 January 23 M8+ Wairarapa Earthquake - what contemporary accounts tell us about it. In: The 1855 Wairarapa Earthquake Symposium - Proceedings Volume. Greater Wellington Regional Council Publication Number: GW/RINV-T-05/205, ISBN: 0909016-87-9, September 2005.

Dutton, A. and Lambeck, K., 2012. Ice volume and sea level during the last interglacial. Science, 337(6091), pp.216-219.

Gardner, T., 2011. Late Holocene deformation, fold, growth and the seismic cycle, Kaikoura Peninsular, South Island, New Zealand. In GSA Annual Meeting in Minneapolis, Oct. 2011. 
Ghani, M. A. (1974). Late Cenozoic vertical crustal movements in the southern North Island, New Zealand. Ph.D. thesis. Victoria University of Wellington, Wellington, New Zealand.

Ghani, M. A. (1978). Late Cenozoic vertical crustal movements in the southern North Island, New Zealand. New Zeal. J. Geol. Geophys. Volume 21, Issue 1, 1978.

Gibb, J.G., 1986. A New Zealand regional Holocene eustatic sea-level curve and its application to determination of vertical tectonic movements. Royal Society of New Zealand Bulletin, 24, pp.377-395.

Grant, K.M., Rohling, E.J., Bar-Matthews, M., Ayalon, A., Medina-Elizalde, M., Ramsey, C.B., Satow, C. and Roberts, A.P., 2012. Rapid coupling between ice volume and polar temperature over the past 150,000 [thinsp] years. Nature, 491(7426), pp.744-747.

Grant, K.M., Rohling, E.J., Ramsey, C.B., Cheng, H., Edwards, R.L., Florindo, F., Heslop, D., Marra, F., Roberts, A.P., Tamisiea, M.E. and Williams, F., 2014. Sea-level variability over five glacial cycles. Nature communications, 5 .

Grantz, A., Plafker, G. and Kachadoorian, R., 1964. Alaska's Good Friday earthquake, March 27, 1964: A preliminary geologic evaluation (Vol. 491). US Department of the Interior, Geological Survey.

Hamling, I.J., Hreinsdóttir, S., Clark, K., Elliott, J., Liang, C., Fielding, E., Litchfield, N., Villamor, P., Wallace, L., Wright, T.J. and D'Anastasio, E., 2017. Complex multifault rupture during the 2016 Mw 7.8 Kaikōura earthquake, New Zealand. Science, 356(6334), p.eaam7194.

Henrys, S., Wech, A., Sutherland, R., Stern, T., Savage, M., Sato, H., Mochizuki, K., Iwasaki, T., Okaya, D., Seward, A. and Tozer, B., 2013. SAHKE geophysical transect reveals crustal and subduction zone structure at the southern Hikurangi margin, New Zealand. Geochemistry, Geophysics, Geosystems, 14(7), pp.2063-2083.

Hull, A.G., 1990: Tectonics of the 1931 Hawke's Bay earthquake. New Zealand Journal of Geology \& Geophysics, Vol. 33: 309-320.

Kopp, R. E., F. J. Simons, J. X. Mitrovica, A. C. Maloof, and M. Oppenheimer. "Probabilistic assessment of sea level during the last interglacial stage." Nature 462, no. 7275 (2009): 863867.

Labeyrie, L.D., Duplessy, J.C. and Blanc, P.L., 1987. Variations in mode of formation and temperature of oceanic deep waters over the past 125,000 years. Nature, 327(6122), pp.477482.

Lambeck, K. and Nakada, M., 1992. Constraints on the age and duration of the last interglacial period and on sea-level variations. Nature, 357(6374), pp.125-128.

Lambeck, K., 2004. Sea-level change through the last glacial cycle: geophysical, glaciological and palaeogeographic consequences. Comptes Rendus Geoscience, 336, 677-689.

Lea, D.W., Martin, P.A., Pak, D.K. and Spero, H.J., 2002. Reconstructing a 350ky history of sea level using planktonic $\mathrm{Mg} / \mathrm{Ca}$ and oxygen isotope records from a Cocos Ridge core. Quaternary Science Reviews, 21(1), pp.283-293.

Li, W.X., Lundberg, J., Dickin, A.P., Ford, D.C., Schwarcz, H.P., McNutt, R. and Williams, D., 1989. High-precision mass-spectrometric uranium-series dating of cave deposits and implications for palaeoclimate studies. 
Lisiecki, L. E., and M. E. Raymo (2005), A Pliocene-Pleistocene stack of 57 globally distributed benthic 18 O records, Paleoceanography, 20, PA1003, doi:10.1029/2004PA001071.

Litchfield, N., Ellis, S., Berryman, K., and Nicol, A., 2007: Insights into subduction-related uplift along the Hikurangi Margin, New Zealand, using numerical modelling. Journal of Geophysical Research, Vol. 112, F02021, doi: 10.1029/2006JF000535.

Litchfield, N.J. and Clark, K.J., 2015. Fluvial terrace formation in the lower Awhea and Pahaoa River valleys, New Zealand: implications for tectonic and sea-level controls. Geomorphology, 231, pp.212-228.

Macharé, J. and Ortlieb, L., 1992. Plio-Quaternary vertical motions and the subduction of the Nazca Ridge, central coast of Peru. Tectonophysics, 205(1-3), pp.97-108.

Marquardt, C., Lavenu, A., Ortlieb, L., Godoy, E. and Comte, D., 2004. Coastal neotectonics in Southern Central Andes: uplift and deformation of marine terraces in Northern Chile (27 S). Tectonophysics, 394(3), pp.193-219.

Marshall, J.S. and Anderson, R.S., 1995. Quaternary uplift and seismic cycle deformation, Peninsula de Nicoya, Costa Rica. Geological Society of America Bulletin, 107(4), pp.463-473.

Matsu'ura, T., Furusawa, A. and Saomoto, H., 2009. Long-term and short-term vertical velocity profiles across the forearc in the NE Japan subduction zone. Quaternary Research, 71(2), pp.227-238.

Matsu'ura, T., Kimura, H., Komatsubara, J., Goto, N., Yanagida, M., Ichikawa, K. and Furusawa, A., 2014. Late Quaternary uplift rate inferred from marine terraces, Shimokita Peninsula, northeastern Japan: A preliminary investigation of the buried shoreline angle. Geomorphology, 209, pp.1-17.

Matsu'ura, T., 2015. Late Quaternary uplift rate inferred from marine terraces, Muroto Peninsula, southwest Japan: Forearc deformation in an oblique subduction zone. Geomorphology, 234, pp.133-150.

McCulloch, M.T. and Esat, T., 2000. The coral record of last interglacial sea levels and sea surface temperatures. Chemical Geology, 169(1), pp.107-129.

McSaveney, M.J., Graham, I.J., Begg, J.G., Beu, A.G., Hull, A.G., Kim, K. and Zondervan, A., 2006. Late Holocene uplift of beach ridges at Turakirae Head, south Wellington coast, New Zealand. New Zealand Journal of Geology and Geophysics, 49(3), pp.337-358.

Merritts, D. and Bull, W.B., 1989. Interpreting Quaternary uplift rates at the Mendocino triple junction, northern California, from uplifted marine terraces. Geology, 17(11), pp.1020-1024.

Merritts, D.J., 1996. The Mendocino triple junction: Active faults, episodic coastal emergence, and rapid uplift. Journal of Geophysical Research: Solid Earth, 101(B3), pp.6051-6070.

Muhs, D. R., Kelsey, H. M., Miller, G. H., Kennedy, G. L., Whelan, J. F., \& McInelly, G. W. (1990). Age estimates and uplift rates for late pleistocene marine terraces' Southern Oregon portion of the Cascadia forearc. J. Geophys. Res. 95, no. B5, 6685-6698.

Muhs, D.R., Rockwell, T.K. and Kennedy, G.L., 1992. Late Quaternary uplift rates of marine terraces on the Pacific coast of North America, southern Oregon to Baja California Sur. Quaternary International, 15, pp.121-133. 
Murray, M.H., Marshall, G.A., Lisowski, M. and Stein, R.S., 1996. The 1992 M= 7 Cape Mendocino, California, earthquake: Coseismic deformation at the south end of the Cascadia megathrust. Journal of Geophysical Research: Solid Earth, 101(B8), pp.17707-17725.

Murray-Wallace, C.V., 2002. Pleistocene coastal stratigraphy, sea-level highstands and neotectonism of the southern Australian passive continental margin - a review. Journal of Quaternary Science, 17(5-6), pp.469-489.

Naish, T.R. and Wilson, G.S., 2009. Constraints on the amplitude of Mid-Pliocene (3.6-2.4 Ma) eustatic sea-level fluctuations from the New Zealand shallow-marine sediment record. Philosophical Transactions of the Royal Society of London A: Mathematical, Physical and Engineering Sciences, 367(1886), pp.169-187.

Nelson, A.R. and Manley, W.F., 1992. Holocene coseismic and aseismic uplift of Isla Mocha, southcentral Chile. Quaternary International, 15, pp.61-76.

Neumann, A.C. and Hearty, P.J., 1996. Rapid sea-level changes at the close of the last interglacial (substage 5e) recorded in Bahamian island geology. Geology, 24(9), pp.775-778.

O'Leary, M.J., Hearty, P.J. and McCulloch, M.T., 2008. Geomorphic evidence of major sea-level fluctuations during marine isotope substage-5e, Cape Cuvier, Western Australia. Geomorphology, 102(3), pp.595-602.

Ortlieb, L., Zazo, C., Goy, J., Hillaire-Marcel, C., Ghaleb, B. and Cournoyer, L., 1996. Coastal deformation and sea-level changes in the northern Chile subduction area (23 S) during the last 330 ky. Quaternary Science Reviews, 15(8-9), pp.819-831.

Ota, Y., D.N. Williams \& K.R. Berryman (1981). Late Quaternary Tectonic Map of New Zealand 1:50,000 Parts Sheets Q27, R27 \& R28. New Zealand Geological Survey, Lower Hutt.

Ota, Y., Pillans, B., Berryman, K., Beu, A., Fujimori, T., Miyauchi, T. Berger, G., Beu, A. G. \& Climo, F. M., 1996. Pleistocene coastal terraces of Kaikoura Peninsula and the Marlborough coast, South Island, New Zealand. New Zealand journal of geology and geophysics, 39(1), 5173.

Pedoja, K., Ortlieb, L., Dumont, J. F., Lamothe, M., Ghaleb, B., Auclair, M., \& Labrousse, B. (2006). Quaternary coastal uplift along the Talara Arc (Ecuador, Northern Peru) from new marine terrace data. Marine Geology, 228(1), 73-91.

Pillans, B., Chappell, J. and Naish, T.R., 1998. A review of the Milankovitch climatic beat: template for Plio-Pleistocene sea-level changes and sequence stratigraphy. Sedimentary Geology, 122(1), pp.5-21.

Plafker, G., 1965: Tectonic deformation associated with the 1964 Alaska earthquake. Science, Vol. 148, No. 3678: 1675-1687.

Plafker, G., 1972. Alaskan earthquake of 1964 and Chilean earthquake of 1960: Implications for arc tectonics. Journal of Geophysical Research, 77(5), pp.901-925.

Potter, E.K., Esat, T.M., Schellmann, G., Radtke, U., Lambeck, K. and McCulloch, M.T., 2004. Suborbital-period sea-level oscillations during marine isotope substages $5 \mathrm{a}$ and $5 \mathrm{c}$. Earth and Planetary Science Letters, 225(1), pp.191-204.

Potter, E.K. and Lambeck, K., 2004. Reconciliation of sea-level observations in the Western North Atlantic during the last glacial cycle. Earth and Planetary Science Letters, 217(1), pp.171-181. 
Rohling, E.J., Grant, K., Hemleben, C.H., Siddall, M., Hoogakker, B.A.A., Bolshaw, M. and Kucera, M., 2008. High rates of sea-level rise during the last interglacial period. Nature Geoscience, $1(1), \mathrm{pp} .38-42$.

Saillard, M., Hall, S. R., Audin, L., Farber, D. L., Hérail, G., Martinod, J., Regard, V., Finkel, R.C. \& Bondoux, F. (2009). Non-steady long-term uplift rates and Pleistocene marine terrace development along the Andean margin of Chile (31 S) inferred from 10 Be dating. Earth and Planetary Science Letters, 277(1), 50-63.

Saillard, M., Hall, S. R., Audin, L., Farber, D. L., Regard, V., \& Hérail, G. (2011). Andean coastal uplift and active tectonics in southern Peru: 10 Be surface exposure dating of differentially uplifted marine terrace sequences (San Juan de Marcona, 15.4 S). Geomorphology, 128(3), 178-190.

Schermer, E. R., Little, T. A., \& Rieser, U. (2009). Quaternary deformation along the Wharekauhau fault system, North Island, New Zealand: Implications for an unstable linkage between active strike-slip and thrust faults. Tectonics, 28(6).

Shackleton, N.J., 2000. The 100,000-year ice-age cycle identified and found to lag temperature, carbon dioxide, and orbital eccentricity. Science, 289(5486), pp.1897-1902.

Siddall, M., Rohling, E.J., Almogi-Labin, A., Hemleben, C., Meischner, D., Schmelzer, I. and Smeed, D.A., 2003. Sea-level fluctuations during the last glacial cycle. Nature, 423(6942), pp.853858.

Siddall, M., J. Chappell, and E-K. Potter. "7. Eustatic sea level during past interglacials." Developments in Quaternary Sciences 7 (2007): 75-92.

Stirling, C.H., Esat, T.M., Lambeck, K. and McCulloch, M.T., 1998. Timing and duration of the Last Interglacial: evidence for a restricted interval of widespread coral reef growth. Earth and Planetary Science Letters, 160(3), pp.745-762.

Subarya, C., Chlieh, M., Prawirodirdjo, L., Avouac, J.P., Bock, Y., Sieh, K., Meltzner, A.J., Natawidjaja, D.H. and McCaffrey, R., 2006. Plate-boundary deformation associated with the great Sumatra-Andaman earthquake. Nature, 440(7080), pp.46-51.

Thompson, W.G. and Goldstein, S.L., 2005. Open-system coral ages reveal persistent suborbital sealevel cycles. Science, 308(5720), pp.401-404.

Thompson, W.G., Curran, H.A., Wilson, M.A. and White, B., 2011. Sea-level oscillations during the last interglacial highstand recorded by Bahamas corals. Nature Geoscience, 4(10), pp.684687.

Vigny, C., Socquet, A., Peyrat, S., Ruegg, J.C., Métois, M., Madariaga, R., Morvan, S., Lancieri, M., Lacassin, R., Campos, J. and Carrizo, D., 2011. The $2010 \mathrm{Mw} 8.8$ Maule megathrust earthquake of Central Chile, monitored by GPS. Science, 332(6036), pp.1417-1421.

Waelbroeck, C., Labeyrie, L., Michel, E., Duplessy, J.C., McManus, J.F., Lambeck, K., Balbon, E. and Labracherie, M., 2002. Sea-level and deep water temperature changes derived from benthic foraminifera isotopic records. Quaternary Science Reviews, 21(1), pp.295-305.

Wilson, K., Litchfield, N., Berryman, K. and Little, T., 2007 (a). Distribution, age, and uplift patterns of Pleistocene marine terraces of the northern Raukumara Peninsula, North Island, New Zealand. New Zealand Journal of Geology and Geophysics, 50(3), pp.181-191. 
Wilson, K., Berryman, K., Cochran, U. and Little, T., 2007 (b): Holocene coastal evolution and uplift mechanisms of the northeastern Raukumara Peninsula, North Island, New Zealand. Quaternary Science Reviews, 26(7), pp.1106-1128.

Zazo, C., Goy, J. L., Dabrio, C. J., Bardají, T., Hillaire-Marcel, C., Ghaleb, B, Gonzalez-Delgado, J-A. \& Soler, V. (2003). Pleistocene raised marine terraces of the Spanish Mediterranean and Atlantic coasts: records of coastal uplift, sea-level highstands and climate changes. Marine Geology, 194(1), 103-133. 


\section{CHAPTER FIVE}

\section{CONCLUSIONS}

\subsection{Summary of Results}

\subsubsection{Outcomes}

This research was undertaken to provide insight into the relationship between tectonic deformation and subduction processes at the southern Hikurangi margin, New Zealand. The two parts to this investigations, on dextral slip on the Wellington Fault, and uplift of Pleistocene marine terraces across the southern North Island, have been carried out to contribute to: i) the understanding of partitioning of margin-parallel plate motion on to upper plate faults; and ii) insight into the relationship between permanent vertical deformation and subduction processes. The latter, in particular, was embarked on to better understand the behaviour of the southern Hikurangi subduction interface, including the hazard posed by subduction earthquakes to this region, which includes New Zealand's capital city of Wellington.

The conclusions of this investigation have provided answers to my research questions of: 1. Do megathrust earthquakes leave a permanent signal of uplift across the southern Hikurangi margin?; 2 . What other processes contribute to the creation of permanent topography across this region?; and 3. Can we contribute to our current understanding of slip partitioning on upper plate faults across the southern North Island?, as summarised below.

\subsubsection{Slip Rate on the Wellington Fault}

Slip on the southern part of the Wellington Fault is documented by fault-offset fluvial terraces at several sites along the Hutt River, north of Wellington. My investigation re-evaluated displacement measurements of fault-offset fluvial terraces at Emerald Hill, Kaitoke Lakes and Dry Creek. Although many of the original terraces at these sites have since been modified due to urban development, I employed photogrammetric analysis of historic aerial photos to produce new digital topographic data from which to quantify original fault displacements. In addition, I used Optically Stimulated Luminescence (OSL) analysis, together with geological and geomorphological evidence, to constrain the ages of these terraces to between $\sim 10 \mathrm{ka}$ and $\sim 100 \mathrm{ka}$. Based on these new data, I estimate an average dextral slip rate for the southernmost 
segment of the Wellington Fault of $6.3 \pm{ }_{1.2}^{1.9} \mathrm{~mm} / \mathrm{yr}(2 \sigma)$ for the last $\sim 100 \mathrm{ka}$. This slip rate is within error of the earlier estimate made by Berryman (1990) of $6.0-7.6 \mathrm{~mm} / \mathrm{yr}$ for the last $\sim 140$ $\mathrm{ka}$, and higher than the estimate of Grapes (1993) of 4.1-5.1 mm/yr since $\sim 140 \mathrm{ka}$. My estimate improves on previous slip rate calculations because it is based on more accurate displacement measurements (previous measurements were made by now-outdated techniques) and uses numerical terrace ages (previously ages were estimated on the basis of regional correlation with other terraces whose ages were better constrained, rather than direct dating).

The results of my investigation, when pooled with results of other recent studies (Langridge et al., 2009; Little et al., 2010) reveal that, during the last $100 \mathrm{ka}$, slip on the Wellington Fault has not accumulated at a steady rate. During the Holocene in particular, the Wellington Fault experienced a period of heightened surface rupture activity between $\sim 8-10 \mathrm{ka}$, a period of relative quiescence between $\sim 4.5-8 \mathrm{ka}$, and finally renewed activity in the last $\sim 4.5 \mathrm{ka}$. These results concur with independent paleoseismological evidence from other sites along the Wellington Fault for the timing of ground rupture events (Van Dissen et al., 1992; Langridge et al., 2009). The time-varying activity observed on the Wellington Fault may be regulated by stress interaction with other, nearby faults, such as the Wairarapa and Awatere faults (Robinson et al., 2011).

These results contribute to our understanding of slip partitioning, or how relative plate motions are accommodated across the margin on upper plate faults, across the southern North Island.

\subsubsection{Distribution and Age of South Coast, North Island Pleistocene Marine Terraces}

With the objective to assess vertical deformation across the southern Hikurangi margin, I have reassessed the distribution of Pleistocene marine terraces along $\sim 100 \mathrm{~km}$ of coastline, between Tongue Point and Cape Palliser, on the south coast of the North Island. Once at sea level, these terraces are now preserved discontinuously along this coast, with shore platform elevations of up to $\sim 400 \mathrm{~m}$ above current-day sea level. Using OSL analysis, together with Global Navigational Satellite Systems (GNSS) elevation surveying, and the morphology and stratigraphy of these terraces and their coverbeds, I have correlated these terraces based on their age of formation. Seven different aged marine terraces have been identified. Recognising that shore platforms are created during sea-level highstands, I used my OSL results - the first radiometrically-determined ages for the majority of these terraces - to attribute them to their relevant, formative Marine Isotope Stage (MIS). The youngest, most extensive and bestpreserved terraces correlate to MIS 5a (peak age $82 \mathrm{ka}$ ), 5c (96 ka), 5e (123 ka) and 7a (196 ka). Based on their position above these dated terraces, terraces from older sea level highstands 
are also present. Although the total number of terraces identified in this investigation accords with previous studies (Ghani, 1974; 1978; Ota et al., 1981), my more reliable shore platform ages differ from previous estimates in many places along the coast and lead to an important revision in our understanding of Quaternary coastal uplift in this region.

In general, the marine terraces are best preserved and most continuous in the Hikurangi forearc region, along the Palliser Bay coast, where they exhibit an overall decrease in elevation in a westward direction. In this region, the highest terraces are found at the easternmost site; at Ngawi, near Cape Palliser, the MIS 5e shore platform is today at an elevation of $\sim 200 \mathrm{~m}$. In comparison, at the westernmost Palliser Bay site of Wharekauhau, the MIS 7a shore platform preserved there is $\sim 10-15 \mathrm{~m}$ above sea level. Moreover, based on additional OSL ages from Schermer et al. (2009) it is likely that the Wharekauhau shore platform was reoccupied during the MIS 5a, 5c and 5e highstands.

In the Axial Ranges of the margin, west of Palliser Bay, the MIS 5e terrace at Baring Head is at an elevation of $\sim 100 \mathrm{~m}$. This abrupt increase in elevation relative to Wharekauhau is likely due to movement on the Wairarapa Fault, which cuts between the two sites, with Baring Head on the upthrown side of the fault. Upper plate faults also offset the marine terraces elsewhere along the south coast. For example, at our westernmost site of Tongue Point, the three terraces preserved there are vertically offset by the Ohariu Fault; the MIS 5e shore platform has an elevation of $\sim 70 \mathrm{~m}$ on the western, upthrown side of the fault and $\sim 30 \mathrm{~m}$ on the eastern side.

\subsubsection{Uplift Rates of South Coast, North Island Pleistocene Marine Terraces}

Post Pleistocene tectonic uplift of the southern Hikurangi margin is recorded by ancient emergent shorelines preserved along the south coast of the North Island. I have used GNSSsurveyed elevation data to calculate the attitude (strike, dip and dip direction) of the main Pleistocene shore platforms along this coast. Using this information, I have calculated their current-day strandline heights and corrected these for sea level elevation at the time of their formation, during MIS 5a, 5c, 5e and 7a, to quantify net tectonic uplift since these terraces were abandoned. The corrected strandline elevations and time of peak sea level during their formative highstand were then used to calculate uplift rates across the southern Hikurangi margin for the last $\sim 200 \mathrm{ka}$.

Uplift rates and shore platform tilting are highest closest to the Hikurangi Trough. Uplift rates of $1.7 \pm 0.1 \mathrm{~mm} / \mathrm{yr}$ and tilting of $2.9^{\circ}$ to the west are observed on the MIS 5e terrace preserved at the easternmost site near Cape Palliser, about $40 \mathrm{~km}$ from the trough. In the forearc region, along the Palliser Bay coast, uplift rates and tilting decrease steadily towards the west with only 
$0.2 \pm 0.1 \mathrm{~mm} / \mathrm{yr}$ of uplift and $0.2^{\circ}$ of tilting, in a southwest direction, observed on the MIS $7 \mathrm{a}$ shore platform at Wharekauhau, about $70 \mathrm{~km}$ from the trough. As mentioned previously, OSL evidence suggests this shore platform was also occupied by the sea during the MIS $5 \mathrm{a}, 5 \mathrm{c}$ and 5e highstands (Schermer et al., 2009), suggesting relatively little uplift at this site over the last $\sim 200$ ka.

Further west, at Baring Head, uplift rates increase relative to Wharekauhau, to between $\sim 0.7$ $1.6 \mathrm{~mm} / \mathrm{yr}$. Uplift calculated from the MIS 5a, MIS 5e and MIS 7a shore platforms at Baring Head are inconsistent across these three time periods. Assuming that the OSL-derived and inferred shore platform ages are correct, this variable uplift rate could reflect alternating periods of activity and quiescence on the nearby Wairarapa Fault, much like that reported on the Wellington Fault (Chapter 2; Ninis et al., 2013). Alternatively, the time-varying uplift rate could reflect a complex interaction between overall uplift at the Baring Head site due to slip on the Wairarapa Fault, and downthrow as a result of slip on the two other faults that offset the terraces at this site, including the Baring Head Fault. Other possible competing processes may be permanent coseismic subsidence from megathrust earthquakes (Clark et al., 2015), and sediment underplating (Henrys et al., 2013).

At Tongue Point, west of Wellington, I have calculated uplift rates of $0.2 \pm 0.1 \mathrm{~mm} / \mathrm{yr}$ and 0.6 $\pm 0.1 \mathrm{~mm} / \mathrm{yr}$ for the MIS 5e shore platform preserved there, on the downthrown and upthrown sides of the Ohariu Fault, respectively.

My uplift rate results are similar to earlier estimates by Ghani $(1974 ; 1978)$ for the easternmost exposed forearc region, at Cape Palliser, and within error of his estimates at Lake Ferry. At Wharekauhau however, my uplift rate of $\sim 0.2 \mathrm{~mm} / \mathrm{yr}$ is much less than his reported $1.0 \mathrm{~mm} / \mathrm{yr}$ due to a difference in the number of terraces identified at this site between the investigations. For sites farther from the Hikurangi Trough, at Baring Head and Tongue Point, my uplift rate estimates are within error of those reported by Ota et al. (1981). However, with OSL ages constraining the timing of formation of these shore platform, most for the first time, coupled with the most recent sea level estimates for their formative highstands, the uplift rate estimates presented herein are the most robust estimates for the southern Hikurangi margin available to date.

The long-wavelength $(\sim 30 \mathrm{~km})$ pattern of uplift evident on the Palliser Bay coast, in the forearc region of the margin, indicates that deep-seated processes, most likely a combination of subduction of the buoyant Hikurangi plateau, and a permanent signal of coseismic uplift from megathrust earthquakes, are responsible for the vertical deformation recorded there. West of 
Palliser Bay, in the Axial Ranges at a distance of $>70 \mathrm{~km}$ from the Hikurangi Trough, the abrupt increases in uplift rate at Baring Head, on the upthrown side of the Wairarapa Fault, and the changes in uplift rates across the Ohariu Fault at Tongue Point, suggest that in addition to sediment underplating, dip slip motion on the major active upper plate faults is a major contributor to tectonic uplift across this region.

These results provide insight into the question of whether megathrust earthquakes leave a permanent signal of uplift across the southern Hikurangi margin. Based on the distribution of uplift and tilting evident on the emergent Pleistocene marine terraces across the Hikurangi forearc, it is likely that they do. With regard to the question of which other processes may be responsible for the creation of permanent topography across the southern Hikurangi margin, I infer that, as with the central and northern Hikurangi margin, subduction of the buoyant Hikurangi Plateau contributes to uplift across the forearc at the southern Hikurangi margin. In the Axial Ranges of the Hikurangi margin, west of the Wharekauhau, the major active upper plate faults contribute to local uplift, while the broader uplift signal is likely influenced by sediment underplating beneath this region.

\subsection{Further Work}

\subsubsection{Age of the Baring Head Marine Terraces}

Baring Head is a unique site in that it has the largest number of preserved Pleistocene terraces of any site on the south coast of the North Island. Six terraces are preserved here, the youngest of which have been correlated to MIS 5a, MIS 5e and MIS 7a. As such, this is an ideal site to test whether rates of uplift have been constant though the last $200 \mathrm{ka}$ and beyond.

As mentioned previously, the uplift rates calculated from the three youngest terraces at Baring Head are discordant across the different time periods that they represent. I have previously discussed possible scenarios that could cause variable rates of apparent uplift at Baring Head, such as alternating periods of activity and quiescence on the Wairarapa Fault, or competition between uplift from the Wairarapa Fault and downthrow on other nearby faults in the upper plate, or permanent coseismic subsidence resulting from megathrust earthquakes (Clarke et al., 2015), and/or sediment underplating (Henrys et al., 2013). Alternatively, the variability in uplift rates could indicate that the ages that I have assigned to one or more of the marine terraces are incorrect. The sample collected from the beach deposits above the shore platform of the main Pleistocene terrace at Baring Head yielded an OSL age of $55.5 \pm 8.7 \mathrm{ka}$, which correlates with the MIS 3/MIS 4 boundary. However, based on geological and stratigraphic evidence, I inferred 
that this platform is in fact of MIS 5a age. Re-sampling the marine sediments on this, and indeed other shore platforms at Baring Head, for radiometric dating, could better constrain the age of the terraces here and resolve the issue of tectonic uplift, and whether or not it has been variable at this site, since the Pleistocene.

\subsubsection{Modelling}

The results of this investigation suggest that, across the southern Hikurangi margin, deep-seated subduction processes contribute to vertical deformation in the forearc region. This is evident in the long-wavelength uplift pattern of elevated Pleistocene marine terraces preserved along the Palliser Bay region of the south coast of the North Island. As described previously in this thesis, there are a number of deep-seated processes that could contribute to the net tectonic uplift observed on the marine terraces since their formation up to $\sim 200 \mathrm{ka}$ ago. Uplift could potentially be due to megathrust earthquakes, a large-scale response to the buoyancy of the subducting plate, or sediment underplating. Distinguishing between these different deep-seated subduction processes as they are reflected in the uplift rates of the overriding plate is nontrivial. In addition, this study has shown that upper plate faulting also contributes to the vertical deformation of the Pleistocene marine terraces, especially to the west of Palliser Bay. Fortunately, we can turn to numerical modelling to provide some insight into which principal processes may be responsible for uplift along the southern Hikurangi margin since the Pleistocene.

Numerical models allow us to simulate a system and evaluate the influence of one or more potential controls on its behaviour at a time. Although they do not necessarily provide absolute answers (e.g. Oreskes et al., 1994) they can provide some insight and constraints on how a complex system works. In studies of plate boundary tectonics, models have previously been run to represent short time frames (coseismic or 100's to 1,000's of years) (e.g. Savage, 1983; Matsu'ura \& Sato, 1989; Marshall \& Anderson, 1995; Flück et al., 1997; Shikakura, 2014; Clark et al., 2015) or, as in this investigation, long time frames $(100,000$ 's of years) (e.g. Valensise \& Ward, 1991; Anderson \& Menking, 1994; Litchfield et al., 2007).

One example in which modelling has been used to test the different scenarios responsible for the long-term uplift of shore platforms is the work of Valensise \& Ward (1991). They examined the effect of repeated rupture along the San Andreas Fault on terraces along $60 \mathrm{~km}$ of coastline at Santa Cruz, California. They employed a model which showed the response of an elastic half-space (representing the coast) to a uniform slip planar dislocation (representing faulting on the San Andreas). Set parameters within the model included fault strike, dip, length and 
width, and fault slip and slip angle. Tectonic uplift predicted from the model was then compared with observational elevations of the shoreline angle of the lowest terrace ( $\sim 100 \mathrm{ka}$ in age), to conclude that this terrace was progressively uplifted by repeated rupture of the San Andreas Fault, and that these events are likely also responsible for the deformation of the older terraces along this coast.

Focusing on the northern terraces at Santa Cruz, Anderson \& Menking (1994) also examined the effect on these features of slip on the offshore San Gregorio Fault, which cuts the coast at the northern extent of these terraces. Using a dipping plane in an elastic half-space, and set parameters such as fault strike, dip, amount of slip and slip direction, and rupture width, they concluded that the long-term net uplift of these terraces are better explained by not only coseismic rupture on the San Andreas Fault, but, also rupture on the San Gregorio Fault.

As mentioned previously in this thesis, Litchfield et al. (2007) employed a finite element model to examine the possible causes of subduction-related uplift along the Hikurangi margin of the North Island of New Zealand. Their model were constructed orthogonal to the margin, parallel to the direction of plate motion, incorporating the crust and upper mantle lithosphere to a depth of $60 \mathrm{~km}$. Set parameters included crustal rheology, convergence rate and an arbitrary load to represent the negative buoyancy of the subducting slab. In one set-up, the slab load was reduced and crustal thickness increased to evaluate the effects of subduction of a more buoyant slab. Another scenario tested subduction of a seamount - this was simulated by imposing a local thickening of the subducting oceanic crust. Results from this study suggest that the buoyancy of the subducting oceanic Hikurangi Plateau could generate low rates of uplift along the margin, while higher uplift rates observed at the central and northern Hikurangi margin are likely due to a combination of sediment underplating and seamount subduction.

In order to evaluate the likely causes of uplift observed on the Pleistocene marine terraces along the south coast of the North Island, an ideal model would be constructed orthogonal to the margin, to best utilise the Pleistocene marine terrace uplift rates, patterns and other conclusions from this study. This alignment is also near-parallel to the plate motion component mainly accommodated for on the subduction interface (e.g. Nicol \& Beavan, 2003).

\subsubsection{Modelling Topography at a Subduction Margin: An Example - 'Flex 2D'}

As described earlier in this thesis, at the Hikurangi margin, the subducting Pacific Plate crust has been shown to thicken across the margin from west to east (e.g. Bourne \& Stuart, 2000; Reyners et al., 2011) with recent findings quantifying the crustal thickness beneath the southern North Island of New Zealand as $\sim 10 \mathrm{~km}$ beneath the west coast, and $\sim 13 \mathrm{~km}$ near the Hikurangi 
Trough; an increase in thickness of $\sim 3 \mathrm{~km}$ over a distance of $\sim 150 \mathrm{~km}$ (P. Herath \& T. Stern, pers. comm. 2017). Here, I employ a model to simulate the vertical deformation at the southern Hikurangi subduction margin in response to this $\sim 3 \mathrm{~km}$ of west-to-east thickening of the subducting Pacific Plate crust. I make use of the freely-available Flex2D (Version 4.4) software, which is a 'flexural' model designed to reproduce how the crust and mantle supports changes in crustal thickness and density (crustal 'load'), and how this is reflected in the surface topography.

In the Flex2D modelling software, the uppermost layers of the earth (the lithosphere - the crust and upper mantle) are represented as an elastic beam floating in a weaker, fluid-like foundation which represents the asthenosphere (Turcotte \& Schubert, 1982; Watts, 2001). This simple model allows the crustal load to be defined (in terms of length, height and density), as well as the foundation, namely the upper mantle (in terms of density and thickness - either constant or variable). The crustal load and upper mantle can be represented either as an infinite elastic beam (along the $\mathrm{x}$-axis) (Hetenyi, 1946) or as a broken beam (a beam with a free end at $\mathrm{x}=0$ ). Model parameters include the Young Modulus (E) and Poisson ratio for the rigidity of the elastic lithosphere.

To determine the likely vertical deformation as a result of the thickening of the subducting crust at the southern Hikurangi margin, in this simple modelling, I define the crustal 'load' to be only that component of subducting crust that is thickened i.e. $\sim 3 \mathrm{~km}$ over $\sim 150 \mathrm{~km}$. I consider a margin-normal profile between the west (Kapiti) coast of the lower North Island, to the Hikurangi Trough, where subduction occurs (Fig. 5a). In this region, I model the crustal thickening as a series of columns increasing in height from $0 \mathrm{~m}$ beneath the west coast, to 3000 $\mathrm{m}$ offshore of the east coast. The density of this crustal 'wedge' has been assumed as $2800 \mathrm{~km} / \mathrm{m}^{3}$, while beneath this, the mantle has been assumed to have a constant thickness of $40 \mathrm{~km}$ and a density of $3300 \mathrm{~km} / \mathrm{m}^{3}$. I modelled the elastic lithosphere as an infinite beam, with Young Modulus (E) and Poisson ratio as per the default settings in Flex2D (70 GPa and 0.25 , respectively). The over-riding Australian plate is not considered in the model, however, it is assumed that this is a rigid structure, such that flexure resulting from the subducting crustal wedge will be transferred directly above it on the surface of the Australian Plate. In this preliminary modelling, I do not attempt to quantify uncertainties in the above parameter values.

The model estimates maximum uplift of $\sim 2100 \mathrm{~m}$ at the eastern extent of the profile (Fig. 5.1b). If we assume a plate convergent rate of $\sim 40 \mathrm{~mm} / \mathrm{yr}$ (e.g. Nicol et al., 2007) constant through time, then this uplift is as a result of $\sim 3.8 \mathrm{My}$ of plate convergence. It follows then the maximum uplift rate over this time, due to the thickening of the subducting plate, is $\sim 0.6 \mathrm{~mm} / \mathrm{yr}$. 
In comparison, the vertical displacement and age of the terraces on at the eastern lower North Island quantify an uplift rate of $\sim 1.7 \mathrm{~mm} / \mathrm{yr}$. The model also predicts uplift across an area extending $\sim 110 \mathrm{~km}$ to the west of the Hikurangi Trough, whereas the monotonic pattern of uplift evident from the Pleistocene marine terraces extends to $\sim 70 \mathrm{~km}$ from the trough. The difference in uplift wavelength estimated by the modelling to that seen in the marine terraces is most likely due to this simple model not accommodating for the vertical deformation signature of upper plate faults; at $\sim 70 \mathrm{~km}$ from the Hikurangi Trough, and further to the west, upper plate faults, such as the Wairarapa Fault, contribute appreciably to the vertical deformation of the topography at the southern Hikurangi margin.
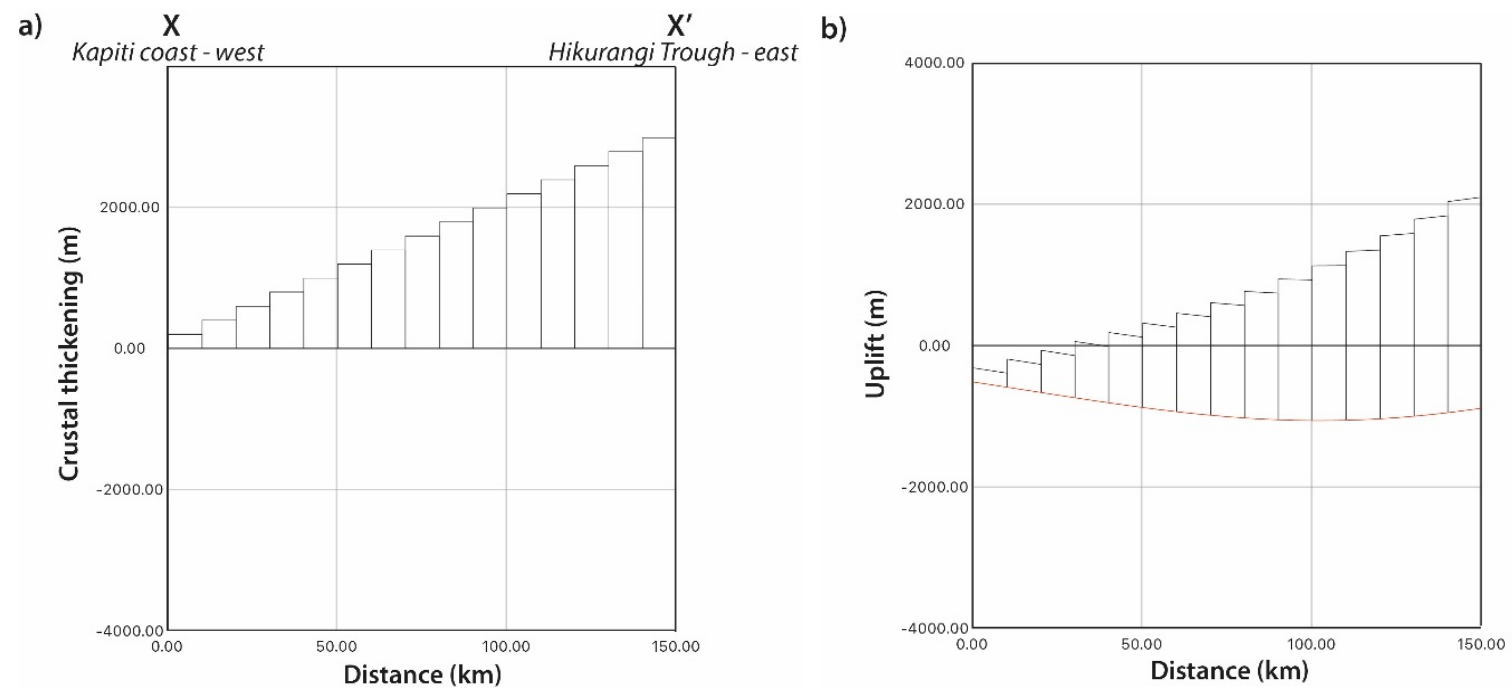

Figure 5.1. a) Flexural model setup, to simulate the effect of crustal 'loading' on vertical deformation across the southern Hikurangi margin. Columns of increasing height represent the $\sim 3 \mathrm{~km}$ west-to-east thickening of the subducted Pacific Plate crust, with density of $2800 \mathrm{~km} / \mathrm{m}^{3,}$ location of X-X' as shown in Fig. 1.1, Fig. 1.3 ; b) Estimated topography (black columns) and crustal deflection (red line) due to subduction of a thickening crust.

This simple modelling, with the aforementioned parameters values, suggests that uplift due to crustal thickening could account for $\sim 30 \%$ of uplift of the lower North Island. Changing the parameters and including uncertainties would test the sensitivity of the uplift estimates produced by this model to parameter values. However, these preliminary estimates, together with uplift rates previously associated with the buoyancy of the Hikurangi Plateau of near $1 \mathrm{~mm} / \mathrm{yr}$ (Litchfield et al., 2007), approach the $\sim 1.7 \mathrm{~mm} / \mathrm{yr}$ of uplift calculated from the Pleistocene marine terraces at the east coast of the North Island.

This conclusion does not discount that the vertical deformation evident on the south coast of the North Island is a result of subduction interface earthquakes, merely that these processes - 
the buoyancy and crustal thickening of the subducting Pacific Plate - could be the dominant processes which cause coseismic deformation at the southern Hikurangi margin to behave inelastically, and thereby remain preserved in the landscape.

\subsubsection{Future Modelling}

To further examine the various subduction processes that could cause tectonic uplift at the southern Hikurangi margin, other modelling could include a number of conditions which are already well understood and can be quantified, such as plate convergence rates (using data from DeMets et al., 1990; 1994; 2010; Wallace et al., 2007), the geometry of the subduction interface (data from Henrys et al., 2013; Williams et al., 2013) and the location of the seismogenic zone (data from Wallace et al., 2004; 2007; 2012). Other conditions that could be estimated and included in the model are geothermal gradient, rheology and elastic properties of the upper plate and subducting slab. Crustal structures such as the location, dip and friction of major, active upper plate faults could also potentially be included.

Parameters within the model can be varied to evaluate the sensitivity of the results to model assumptions and parametric uncertainties, thereby allowing uplift in response to one or more deep-seated subduction processes to be evaluated. For example, in testing for the effects of megathrust earthquakes, the area of rupture of the subduction interface could be defined based on the known location of the seismogenic zone, while the recurrence interval of these megathrust events, and also the area of rupture, could be varied. Because megathrust earthquakes would have a return period much less than the long-term deformation under consideration here, the model would need to span a period of several hundred earthquakes over $\sim 200 \mathrm{ka}$. Theoretical results of the simulation could then be compared against the current-day topography, specifically the net uplift evident on the Pleistocene marine terraces, to determine which modelled scenario is more likely and therefore determine which process (or processes) best account for the uplift pattern of the southern North Island.

In summary, tectonic modelling which includes well-quantified parameters and is further constrained by the uplift rates and tilting patterns reported in this study could provide further insight into the subduction zone geodynamics at the southern Hikurangi margin. A better understanding of the processes responsible for tectonic deformation across this region, in particular the part played by the locked subduction interface and associated megathrust earthquakes, would further quantify earthquake hazard in this region. 


\section{References}

Anderson, R.S. and Menking, K.M., 1994. The Quaternary marine terraces of Santa Cruz, California: Evidence for coseismic uplift on two faults. Geological Society of America Bulletin, 106(5), pp.649-664.

Berryman, K. R. (1990). Late Quaternary movement on the Wellington Fault in the Upper Hutt area, New Zealand, New Zeal. J. Geol. Geophys. 33 257-270.

Bourne, M. and Stuart, G., 2000. ScSp observed on North Island, New Zealand: implications for subducting plate structure. Geophysical Journal International, 142(3), pp.925-932.

Clark, K.J., Hayward, B.W., Cochran, U.A., Wallace, L.M., Power, W.L. and Sabaa, A.T., 2015. Evidence for past subduction earthquakes at a plate boundary with widespread upper plate faulting: Southern Hikurangi margin, New Zealand. Bulletin of the Seismological Society of America.

DeMets, C., Gordon, R. G., Argus, D. F., and Stein, S., 1990. Current plate motions, Geophys. J. Int. $101425-478$.

DeMets, C., Gordon, R. G., Argus, D. F., and Stein, S., 1994. Effect of Recent Revisions to the Geomagnetic Reversal Time Scale on Estimates of Current Plate Motions, Geophys. Res. Lett. $212191-2194$.

DeMets, C., Gordon, R.G. and Argus, D.F., 2010. Geologically current plate motions. Geophysical Journal International, 181(1), pp.1-80.

Flück, P., Hyndman, R.D. and Wang, K., 1997. Three-dimensional dislocation model for great earthquakes of the Cascadia subduction zone. Journal of Geophysical Research: Solid Earth, 102(B9), pp.20539-20550.

Ghani, M. A. (1974). Late Cenozoic vertical crustal movements in the southern North Island, New Zealand. Ph.D. thesis. Victoria University of Wellington, Wellington, New Zealand.

Ghani, M. A. (1978). Late Cenozoic vertical crustal movements in the southern North Island, New Zealand. New Zeal. J. Geol. Geophys. Volume 21, Issue 1, 1978.

Grapes, R. (1993). Terrace correlation, dextral displacements, and slip rate along the Wellington Fault, North Island, New Zealand (Letters to the Editor), New Zeal. J. Geol. Geophys. 36 131-135.

Henrys, S., Wech, A., Sutherland, R., Stern, T., Savage, M., Sato, H., Mochizuki, K., Iwasaki, T., Okaya, D., Seward, A. and Tozer, B., 2013. SAHKE geophysical transect reveals crustal and subduction zone structure at the southern Hikurangi margin, New Zealand. Geochemistry, Geophysics, Geosystems, 14(7), pp.2063-2083.

Hetenyi, M., Beams on elastic foundation, 1946. Ann Arbor: University of Michigan Press.

Langridge, R., P. Villamor, R. Van Dissen and T. Little (2009). It's Our Fault - Wellington Fault paleo-earthquake investigation: Final report, GNS Science Consultancy Report 2008/344, June 2009.

Lensen, G. J. (1973). Guidebook for Excursion A10: Central New Zealand, IX INQUA Congress 1973, Christchurch, New Zealand, 2-24.

Litchfield, N., S. Ellis, K. Berryman, \& A. Nicol, 2007: Insights into subduction-related uplift along the Hikurangi Margin, New Zealand, using numerical modelling. Journal of Geophysical Research, Vol. 112, F02021, doi: 10.1029/2006JF000535. 
Little, T. A., R. Van Dissen, U. Rieser, E. G. C. Smith, and R. Langridge (2010). Coseismic strike-slip at a point during the last four earthquakes on the Wellington Fault near Wellington, New Zealand, J. Geophys. Res. 115, B05403, doi:10.1029/2009JB006589, 2010.

Marshall, J.S. and Anderson, R.S., 1995. Quaternary uplift and seismic cycle deformation, Peninsula de Nicoya, Costa Rica. Geological Society of America Bulletin, 107(4), pp.463-473.

Matsu'Ura, M. and Sato, T., 1989. A dislocation model for the earthquake cycle at convergent plate boundaries. Geophysical Journal International, 96(1), pp.23-32.

McSaveney, M. J., Graham, I. J., Begg, J. G., Beu, A. G., Hull, A. G., Kim, K., \& Zondervan, A. (2006). Late Holocene uplift of beach ridges at Turakirae Head, south Wellington coast, New Zealand. New Zealand Journal of Geology and Geophysics, 49(3), 337-358.

Nicol, A., and Beavan, J., 2003: Shortening of an overriding plate and its implications for slip on a subduction thrust, central Hikurangi margin, New Zealand. Tectonics, Vol. 22, No. 6, doi10.1029/2003TC001521.

Ninis, D., Little, T.A., Van Dissen, R.J., Litchfield, N.J., Smith, E.G., Wang, N., Rieser, U. and Henderson, C.M., 2013. Slip rate on the Wellington fault, New Zealand, during the late Quaternary: Evidence for variable slip during the Holocene. Bulletin of the Seismological Society of America, 103(1), pp.559-579.

Oreskes, N., Shrader-Frechette, K. and Belitz, K., 1994. Verification, validation, and confirmation of numerical models in the earth sciences. Science, 263(5147), pp.641-646.

Ota, Y., D.N. Williams \& K.R. Berryman (1981). Late Quaternary Tectonic Map of New Zealand 1:50,000 Parts Sheets Q27, R27 \& R28. New Zealand Geological Survey, Lower Hutt.

Reyners, M., Eberhart-Phillips, D. and Bannister, S., 2011. Tracking repeated subduction of the Hikurangi Plateau beneath New Zealand. Earth and Planetary Science Letters, 311(1-2), pp.165-171.

Robinson, R., R. Van Dissen and N. Litchfield (2011). Using synthetic seismicity to evaluate seismic hazard in the Wellington region, New Zealand, Geophys. J. Int. 187 510-528.

Savage, J.C., 1983. A dislocation model of strain accumulation and release at a subduction zone. Journal of Geophysical Research: Solid Earth, 88(B6), pp.4984-4996.

Schermer, E. R., Little, T. A., \& Rieser, U. (2009). Quaternary deformation along the Wharekauhau fault system, North Island, New Zealand: Implications for an unstable linkage between active strike-slip and thrust faults. Tectonics, 28(6).

Shikakura, Y., 2014. Marine terraces caused by fast steady uplift and small coseismic uplift and the time-predictable model: Case of Kikai Island, Ryukyu Islands, Japan. Earth and Planetary Science Letters, 404, pp.232-237.

Turcotte, D.L. and Schubert, G., 1982. Geodynamics: Applications of continuum physics to geological problems, $450 \mathrm{pp}$.

Valensise, G. and Ward, S.N., 1991. Long-term uplift of the Santa Cruz coastline in response to repeated earthquakes along the San Andreas fault. Bulletin of the Seismological Society of America, 81(5), pp.1694-1704.

Van Dissen, R., K. R. Berryman, J. R. Pettinga and N. L. Hill (1992). Paleoseismicity of the Wellington-Hutt Valley segment of the Wellington Fault, North Island, New Zealand, New Zeal. J. Geol. Geophys. 35 165-176. 
Wallace, L.M., Beavan, J., McCaffrey, R. and Darby, D., 2004. Subduction zone coupling and tectonic block rotations in the North Island, New Zealand. Journal of Geophysical Research: Solid Earth, 109(B12).

Wallace, L.M., Beavan, J., McCaffrey, R., Berryman, K. and Denys, P., 2007. Balancing the plate motion budget in the South Island, New Zealand using GPS, geological and seismological data. Geophysical Journal International, 168(1), pp.332-352.

Wallace, L. M., Barnes, P., Beavan, J., Van Dissen, R. J., Litchfield, N. J., Mountjoy, J., Langridge, R. M., Lamarche, G., and Pondard, H., 2012. The kinematics of a transition from subduction to strike-slip: an example from the central New Zealand plate boundary, J. Geophys. Res. Solid Earth, doi: 10.1029/2011JB008640.

Watts, A.B., 2001. Isostasy and Flexure of the Lithosphere. Cambridge University Press.

Williams, C.A., Eberhart-Phillips, D., Bannister, S., Barker, D.H., Henrys, S., Reyners, M. and Sutherland, R., 2013. Revised interface geometry for the Hikurangi subduction zone, New Zealand. Seismological Research Letters, 84(6), pp.1066-1073. 


\section{APPENDICES}

\section{APPENDIX A}

Optically STIMULATED LUMINESCENCE (OSL) DATING:

TECHNICAL REPORT AND RESULTS

BY N. WANG \& U. RIESER

\section{APPENDIX B}

FLUVIAL TERRACE STRATIGRAPHIC DESCRIPTIONS

INCLUDING OSL SAMPLE LOCI AND RESULTS

\section{APPENDIX C}

TERRACE AgE ESTIMATION

USING CONDITIONAL PROBABILITIES AND BAYESIAN STATISTICS

BY E.G.C SMITH

\section{APPENDIX D}

Shore PlatForm Plane FitTing DATA

\section{APPENDIX E}

MARINE TERRACE STRATIGRAPHIC DESCRIPTIONS

INCLUDING OSL SAMPLE LOCI AND RESULTS 


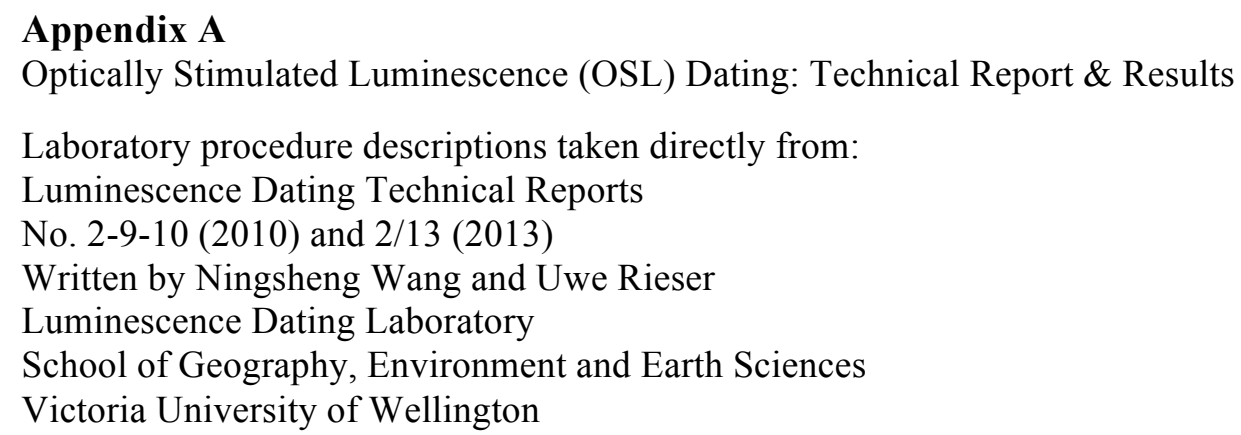

\section{Sample Preparation}

Samples first had their outer surfaces removed. Of the removed outer scrapings, $100 \mathrm{~g}$ was dried in an oven and then milled. This homogenised sample material was sealed in air-tight perspex containers and then stored for at least four weeks in preparation for gamma spectrometer analysis. This storage time minimizes the loss of the short lived noble gas ${ }^{222} \mathrm{Rn}$ and allows ${ }^{226} \mathrm{Ra}$ to reach equilibrium with its daughters ${ }^{214} \mathrm{~Pb}$ and ${ }^{214} \mathrm{Bi}$. A plastic cube was then filled with the remaining scrapings in preparation for water content measurements.

About $150 \mathrm{~g}$ of fresh, unexposed light sample material was treated in $10 \% \mathrm{HCl}$. This was carried out overnight until all carbonate was removed by the reaction. Following this treatment, the sample was further reacted overnight with $10 \% \mathrm{H}_{2} \mathrm{O}_{2}$ in order to remove organic matter.

The next step involved $200 \mathrm{ml}$ CBD solution ( $71 \mathrm{~g}$ sodium citrate, $8.5 \mathrm{~g}$ sodium bicarbonate, and $2 \mathrm{~g}$ sodium dithionate per litre of distilled water) being added to the sample for 12 hours to remove iron oxide coatings. After every chemical treatment procedure, distilled water was used to wash the sample several times.

After chemical treatment, calgon solution ( $1 \mathrm{~g}$ sodium hexametaphosphate per litre distilled water) was added to make a thick slurry. This slurry was placed into an ultrasonic bath and mechanically agitated for 1 hour. The sample was then placed into a $1 \mathrm{~L}$ measuring cylinder and filled with a certain amount of distilled water to separate out the 4-11 $\mu$ m grains according to Stokes' Law. The 4-11 $\mu \mathrm{m}$ grains were then rinsed with ethanol and acetone and a suspension of these grains were then deposited evenly onto 70 aluminium disks (diameter $9.8 \mathrm{~mm}$ ).

\section{Measurement}

Luminescence age was determined by two factors: the equivalent dose (De) (obtained from the lab equivalents to the paleodose absorbed by samples during burial time in the natural environment since their last exposure to the light) and the dose rate (amount dose received by the sample each 
year). It involves measurement of luminescence for determination of De and concentrations of ${ }^{238} \mathrm{U},{ }^{232} \mathrm{Th},{ }^{40} \mathrm{~K}$ and water contents (used to determine of dose rate)

\section{Determination of Equivalent Dose (De) using MAAD and SAR}

The test dose obtained from an initial test measurement was used for the Multiple Aliquot Additive Dose (MAAD) technique. As luminescence vary between disks, all disks for MAAD need to be normalised before $\beta$ irradiation. 0.1 second infrared measurements were taken before irradiation of all aliquots. Six groups (30 disks divided by five) were $\beta$ irradiated up to five times of the test dose. Beta irradiation were done on the Riso TL-DA- $15{ }^{90} \mathrm{Sr} / \mathrm{Y} \beta$ irradiator, calibrated against ${ }^{60} \mathrm{Co}$ gamma source, of Simon Fraser University, Vancouver, Canada, with about 3\% uncertainty. Three groups (three disks per group) were $\alpha$ irradiated up to three times of the test dose. The $\alpha$ irradiation was carried out on a 241 Am irradiator, supplied and calibrated by ELSEC Littlemore, UK. These 39 disks together with nine non-irradiated disks (total of 48 disks) were stored for four weeks to relax the crystal lattice after irradiation.

After storage, the 48 disks were preheated for five minutes at $230^{\circ} \mathrm{C}$, then were measured using a Riso TL-DA-15 reader with infrared diodes at $880 \mathrm{~nm}$ used to deliver a stimulated beam (30 $\mathrm{mW} / \mathrm{cm}^{2}$ ) at the room temperature for $100 \mathrm{~s}$. Blue luminescence centred about $410 \mathrm{~nm}$ emission from feldspar was then detected by an EMI 9235QA photomultiplier fixed behind two filters consisting of a Schott BG-39 and Kopp 5-58.

Luminescence growth curves ( $\beta$ induced luminescence intensity versus added dose) were constructed by using the first few seconds of the shine down curves and subtracting the average of the last $20 \mathrm{~s}$, along with the so called late light which is thought to be a mixture of background and hardly bleachable components. Extrapolation of this growth curve to the dose axis was obtained using the equivalent dose De as a paleodose. The shine plateau was checked to be flat after this manipulation.

A similar plot for the alpha irradiated disks allows for an estimation of $\alpha$ efficiency and a-value (avalue is measured by comparing the luminescence induced by alpha irradiation with that induced by beta or gamma irradiation). The a-value was for dose rate calculations.

The Single Aliquot Regenerative Method (SAR) was used to determine the equivalent doses. This technique is described by Murray and Wintle (2000). For the SAR method, a number of aliquots (disks) were subjected to a repetitive cycle of irradiation, preheating and measurement. Firstly, natural shine down curves were measured after preheating. Then shine down curves were measured for the next four or five cycles for different beta doses. From the variety of shine down curves, a luminescence growth curve ( $\beta$ induced luminescence versus added dose) was established. This was 
used to determine the equivalent dose (equivalent to the palaeodose). The measurement for the aliquots resulted in a variety of equivalent doses, spread over the arithmetic mean of the data.

In order to correct potential sensitivity changes from cycle to cycle, the luminescence response to a test dose was measured after preheating between cycles. Preheating temperature and time was $260^{\circ} \mathrm{C}$ for $20 \mathrm{~s}$; and measurement time was $100 \mathrm{~s}$ at room temperature.

Examples of MAAD and SAR plots from select samples analysed as part of this investigation are provided in Fig. A.1 to Fig. A.11.

\section{Determination of Dose Rate}

Dose rate consisted of two parts (i) Dose rate from the sample's burial environment; and (ii) Dose rate from cosmic rays.

Dose rate from the sample's burial environment was determined by radionuclide contents of ${ }^{238} U$, ${ }^{232} \mathrm{Th}$ and ${ }^{40} \mathrm{~K}$, a-value and water content. Gamma rays produced from sample material were counted for a minimum time of $24 \mathrm{hrs}$ by a high resolution and broad energy gamma spectrometer. The spectra were then analysed using GENIE2000 software. The contents of U, Th and K were obtained by comparison with standard samples. The dose rate calculation was based on the activity concentration of the nuclides ${ }^{40} \mathrm{~K},{ }^{208} \mathrm{Tl},{ }^{212} \mathrm{~Pb},{ }^{228} \mathrm{Ac},{ }^{214} \mathrm{Bi},{ }^{214} \mathrm{~Pb}$ and ${ }^{226} \mathrm{Ra}$ using dose rate conversion factors published by Adamiec and Aitken (1998). Water content was measured as weight of water divided by dry weight of the sample taking into account a $10 \%$ uncertainty.

Dose rates from cosmic rays were determined by the depth of sample below the surface along with its longitude, latitude and altitude, using conventional formulae and factors published by Prescott \& Hutton (1994). 

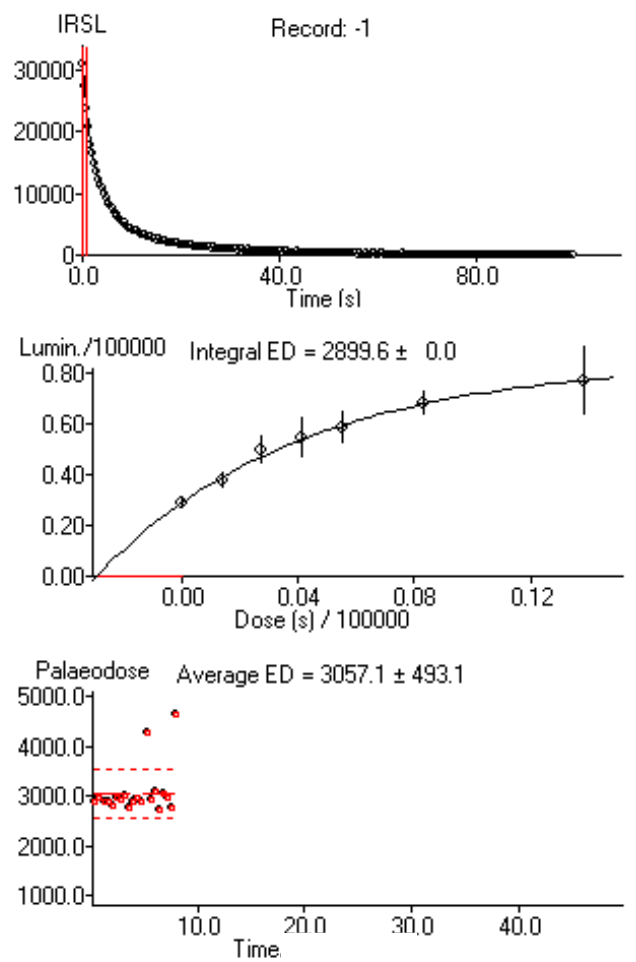

Figure A.1. MAAD analysis plots for sample WLL850. Top plot: Luminescence 'shine down' curve (photon counts / time (s)); Middle plot: Luminescence versus various dose response 'growth' curve (sensitivity corrected luminescence ( $\mathrm{Li} / \mathrm{Ti}$ ) / dose (s)); Bottom plot: Dose intercepts versus illumination time (s).
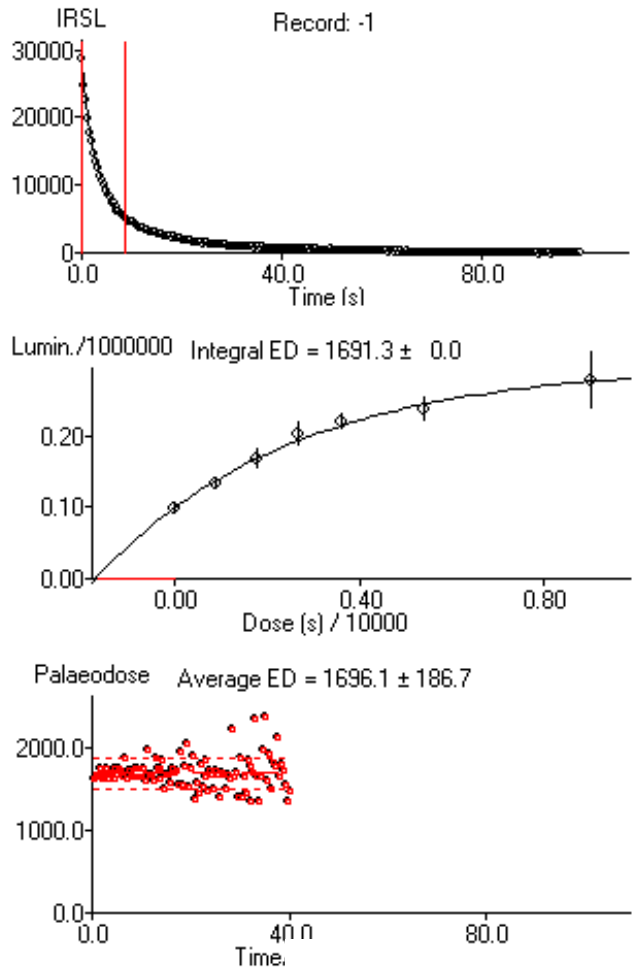

Figure A.2. MAAD analysis plots for sample WLL851. Top, middle and bottom plot explanations as for Figure A.1. 

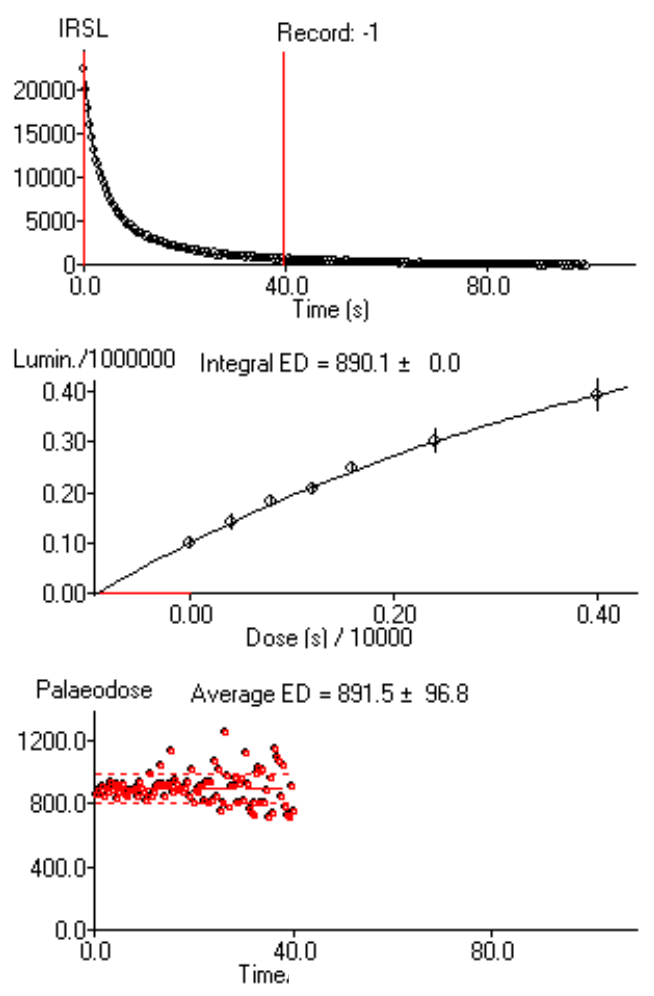

Figure A.3. MAAD analysis plots for sample WLL869. Top, middle and bottom plot explanations as for Figure A.1.
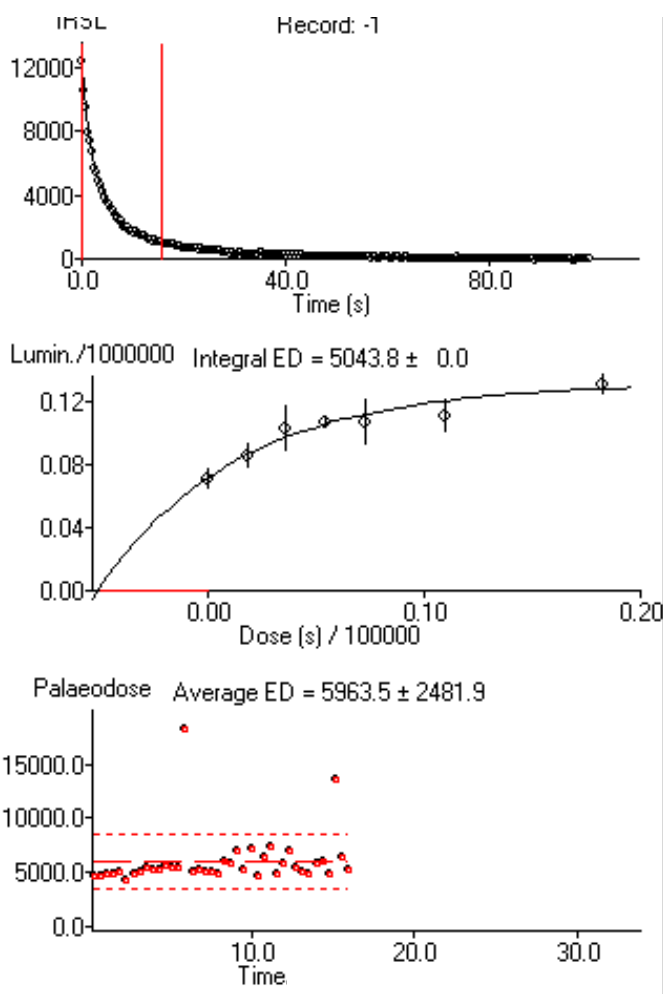

Figure A.4. MAAD analysis plots for sample WLL847. Top, middle and bottom plot explanations as for Figure A.1. 

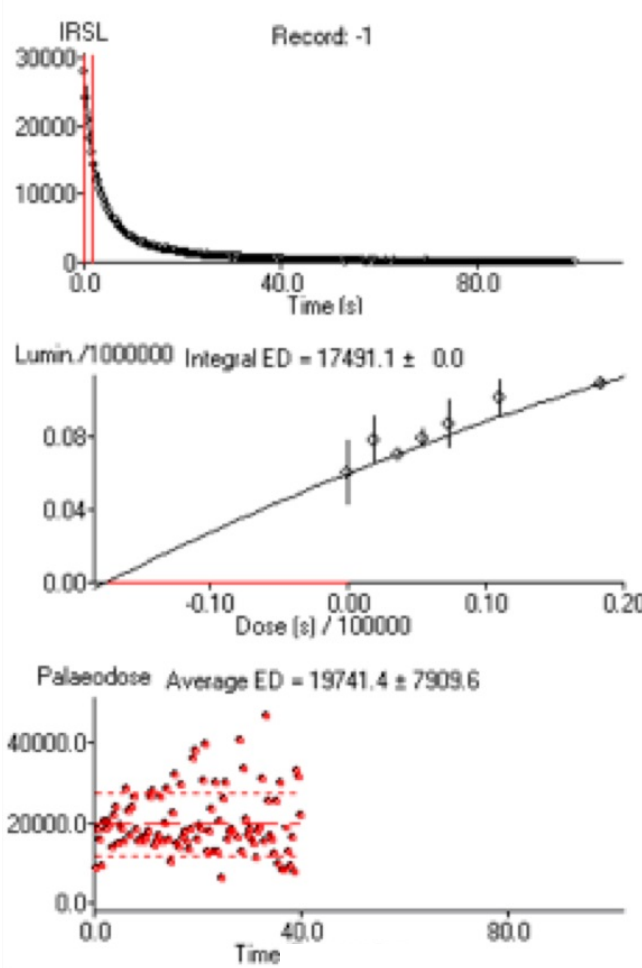

Figure A.5. MAAD analysis plots for sample WLL816. Top, middle and bottom plot explanations as for Figure A.1.
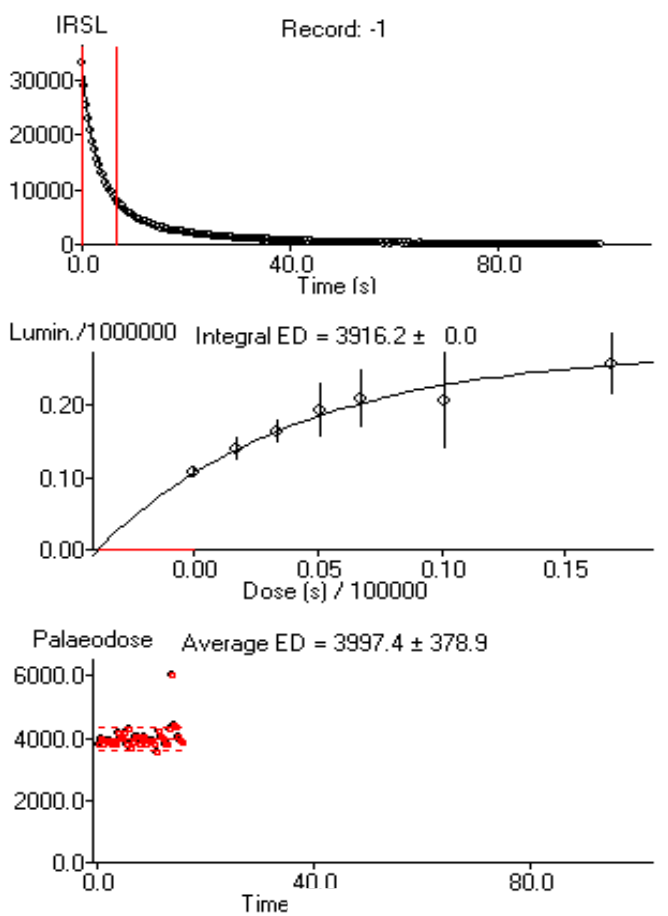

Figure A.6. MAAD analysis plots for sample WLL841. Top, middle and bottom plot explanations as for Figure A.1. 

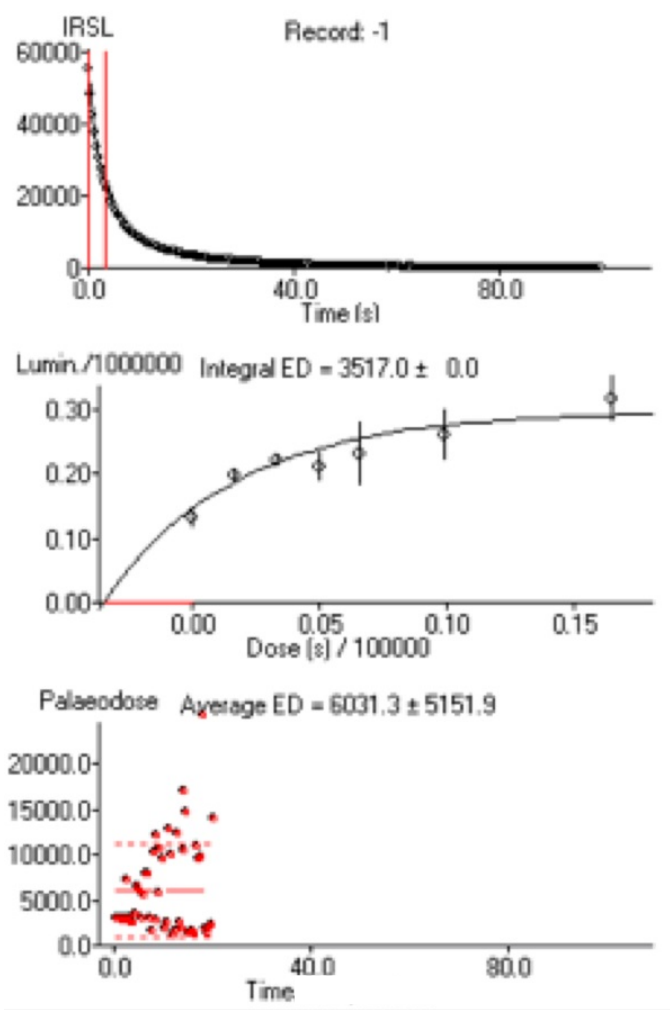

Figure A.7. MAAD analysis plots for sample WLL840. Top, middle and bottom plot explanations as for Figure A.1.
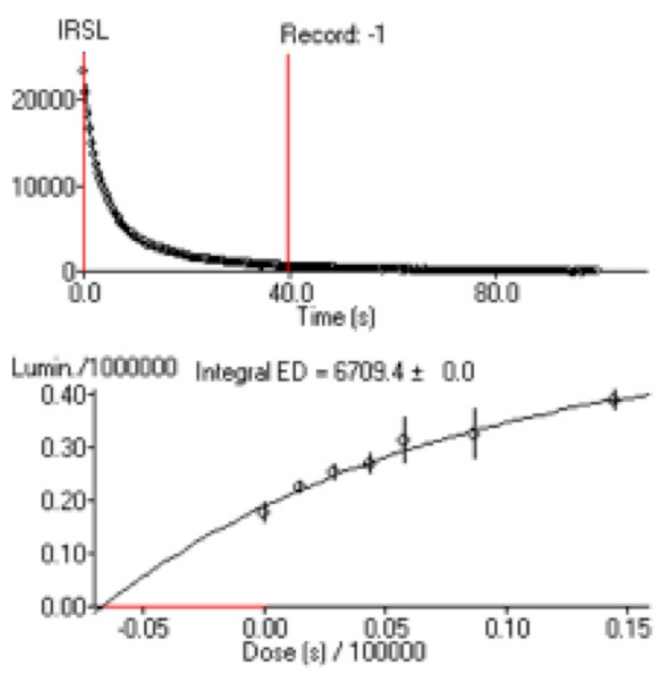

Palaoodose Average ED $\pm 7690.6 \pm 2362.3$

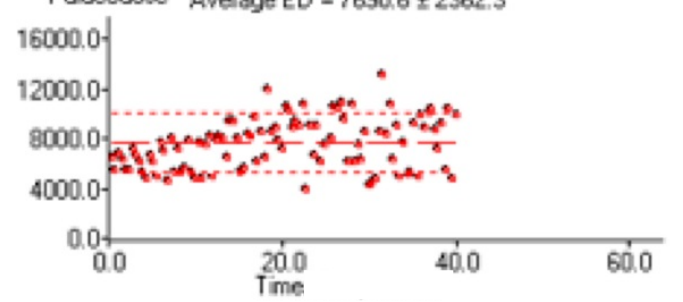

Figure A.8. MAAD analysis plots for sample WLL855. Top, middle and bottom plot explanations as for Figure A.1. 

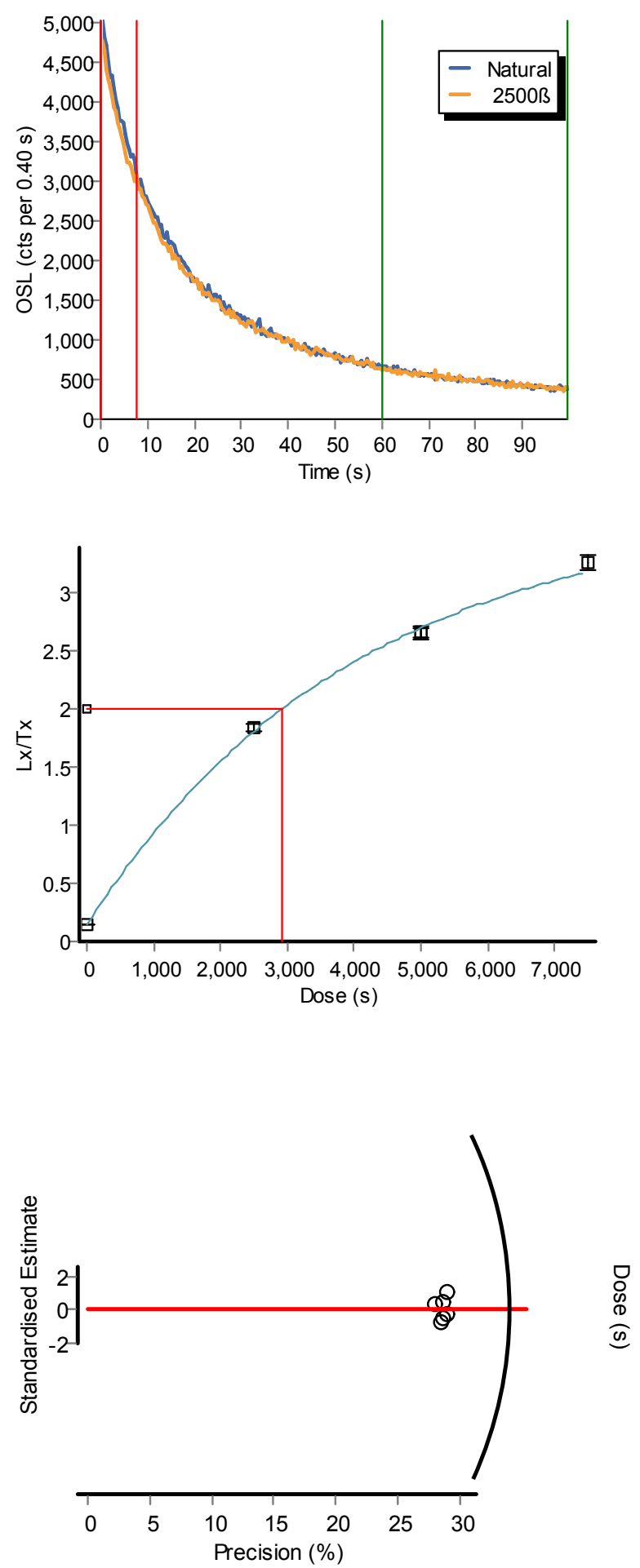

Figure A.9. SAR analysis plots for sample WLL855. Top and middle plot explanations as per Fig. A.1. Bottom curve: Dose distribution radial plot. 

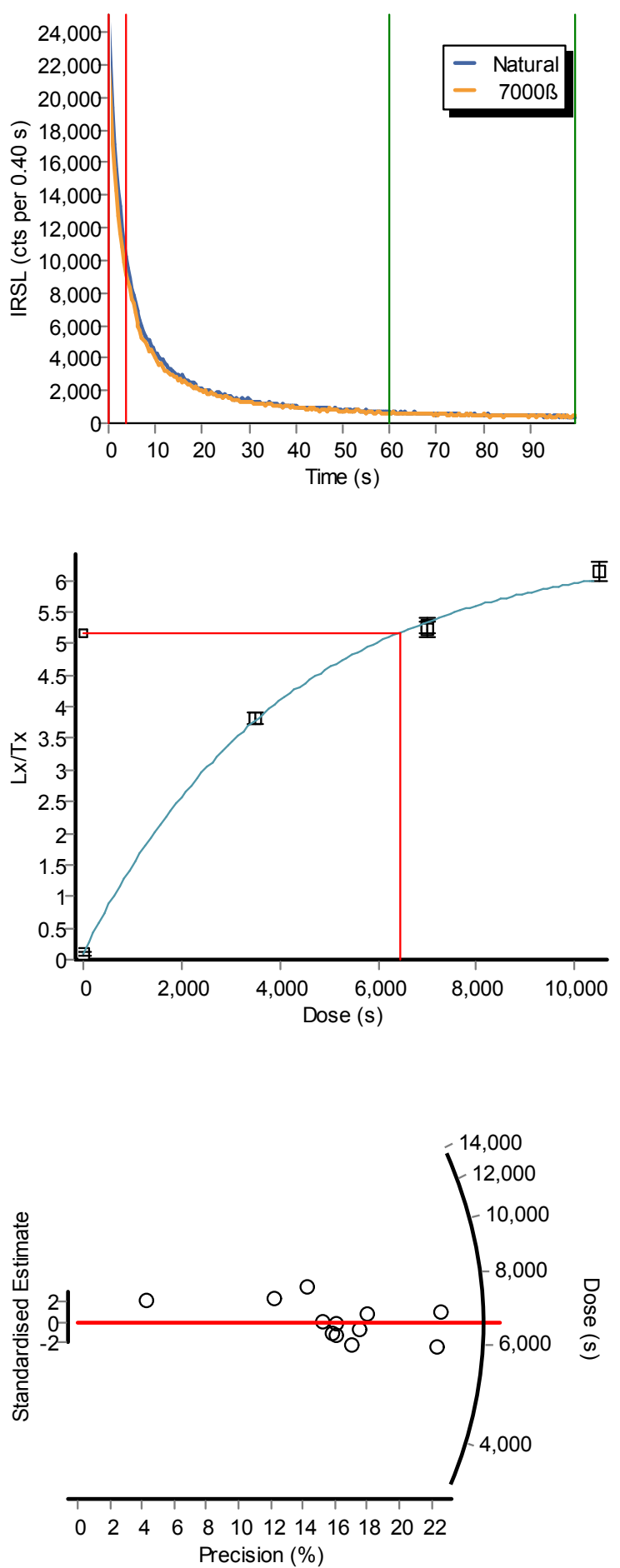

Figure A.10. SAR analysis plots for sample WLL877. Top and middle plot explanations as per Fig. A.1. Bottom curve: Dose distribution radial plot. 

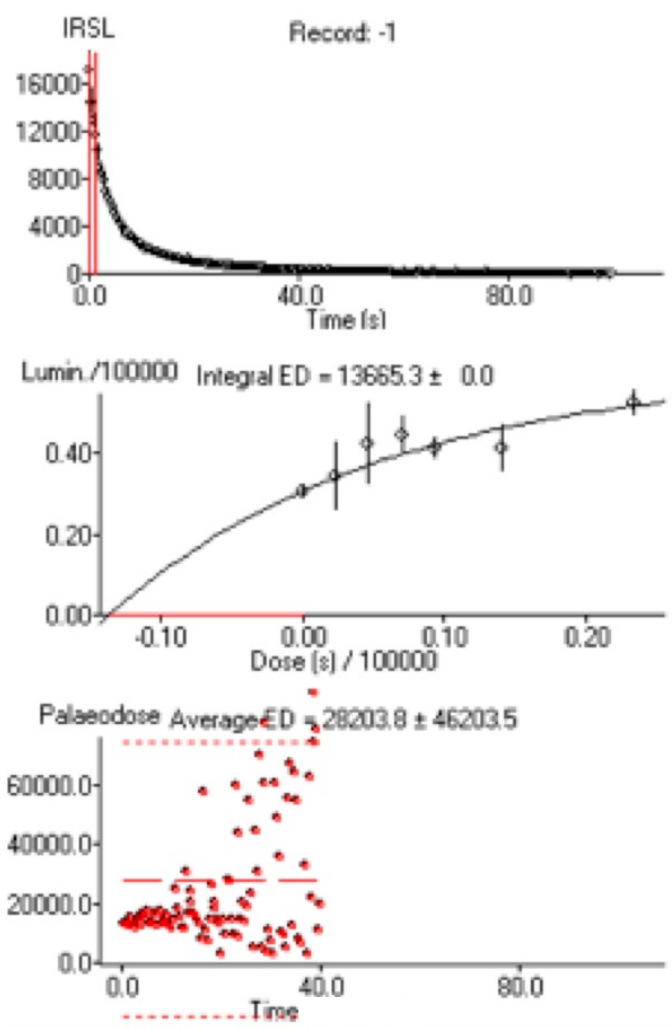

Figure A.11. MAAD analysis plots for sample WLL876. Top, middle and bottom plot explanations as for Figure A.1. 


\section{Results}

Table A.1 Cosmic Dose Rates

\begin{tabular}{|c|c|c|c|}
\hline Laboratory Code & $\begin{array}{l}\text { Depth Below Surface } \\
\text { (m) }\end{array}$ & $\begin{array}{c}\text { Cosmic Ray Dose Rate } \\
(\mathrm{Gy} / \mathrm{ka})\end{array}$ & Field Code \\
\hline WLL482 & 3.0 & $0.1376 \pm 0.0069$ & WLL482 \\
\hline WLL499 & 0.3 & $0.1982 \pm 0.0099$ & WLL499 \\
\hline WLL855 & 6.84 & $0.087 \pm 0.004$ & DOG684 \\
\hline WLL856 & 5.52 & $0.101 \pm 0.005$ & DOG552 \\
\hline WLL857 & 4.84 & $0.110 \pm 0.006$ & DOG484 \\
\hline WLL858 & 4.20 & $0.118 \pm 0.006$ & DOG420 \\
\hline WLL859 & 2.95 & $0.139 \pm 0.007$ & DOG295 \\
\hline WLL860 & 1.55 & $0.167 \pm 0.008$ & DOG155 \\
\hline WLL861 & 1.10 & $0.177 \pm 0.009$ & DOG110 \\
\hline WLL879 & 1.25 & $0.178 \pm 0.009$ & COW125 \\
\hline WLL880 & 2.10 & $0.158 \pm 0.008$ & COW210 \\
\hline WLL881 & 2.93 & $0.142 \pm 0.007$ & COW293 \\
\hline WLL882 & 3.27 & $0.136 \pm 0.007$ & VERGE327 \\
\hline WLL862 & 7.0 & $0.0881 \pm 0.0044$ & KL-1OSL \\
\hline WLL863 & 0.64 & $0.1949 \pm 0.0097$ & KL-2OSL \\
\hline WLL864 & 0.80 & $0.1906 \pm 0.0095$ & KL-3OSL \\
\hline WLL865 & 1.10 & $0.1829 \pm 0.0091$ & KL-4OSL \\
\hline WLL866 & 1.25 & $0.1791 \pm 0.0090$ & KL-5OSL \\
\hline WLL816 & 6.15 & $0.0952 \pm 0.0048$ & NWI 1A \\
\hline WLL817 & 1.35 & $0.1736 \pm 0.0087$ & NWI 2 \\
\hline WLL818 & 1.78 & $0.1638 \pm 0.0082$ & PAL3A \\
\hline WLL819 & 1.60 & $0.1678 \pm 0.0084$ & PAL3B \\
\hline WLL820 & 1.37 & $0.1731 \pm 0.0087$ & PAL4 \\
\hline
\end{tabular}




\begin{tabular}{|c|c|c|c|}
\hline WLL840 & 15.75 & $0.0382 \pm 0.0019$ & WHAN01 \\
\hline WLL841 & 15.65 & $0.0385 \pm 0.0019$ & WHAN02 \\
\hline WLL847 & 6.15 & $0.0952 \pm 0.0048$ & NWI 1B \\
\hline WLL848 & 5.7 & $0.0989 \pm 0.0049$ & WSHP01 \\
\hline WLL849 & 5.7 & $0.0989 \pm 0.0049$ & WSHP02 \\
\hline WLL850 & 3.7 & $0.1258 \pm 0.0063$ & WSHP03 \\
\hline WLL851 & 1.3 & $0.1725 \pm 0.0086$ & WSHP04 \\
\hline WLL875 & 10 & $0.0656 \pm 0.0033$ & GC-1a \\
\hline WLL876 & 4.0 & $0.1212 \pm 0.0061$ & Wpapa 1 \\
\hline WLL877 & 4.0 & $0.1212 \pm 0.0061$ & Wpapa 2 \\
\hline WLL1038 & 5.8 & $0.1040 \pm 0.0052$ & BARHD02 \\
\hline WLL1039 & 4.8 & $0.1170 \pm 0.0058$ & BARHD03 \\
\hline WLL933 & 3.5 & $0.1402 \pm 0.0070$ & BAR01 \\
\hline WLL867 & 1.30 & $0.1744 \pm 0.0087$ & TP01 \\
\hline WLL868 & 1.30 & $0.1744 \pm 0.0087$ & TP02 \\
\hline WLL869 & 0.70 & $0.1895 \pm 0.0095$ & TP03 \\
\hline
\end{tabular}


Table A.2 Water Contents, Radionuclide Contents

\begin{tabular}{|c|c|c|c|c|c|c|c|}
\hline $\begin{array}{l}\text { Laboratory } \\
\text { Code }\end{array}$ & $\begin{array}{c}\text { Water } \\
\text { content } \\
\%\end{array}$ & $\begin{array}{l}\mathrm{U} \text { (ppm) } \\
\text { from } \\
234 \mathrm{Th}\end{array}$ & $\begin{array}{c}\mathrm{U}(\mathrm{ppm}) \\
\text { from } \\
226 \mathrm{Ra} \\
214 \mathrm{~Pb} \\
214 \mathrm{Bi}\end{array}$ & $\begin{array}{l}\mathrm{U}(\mathrm{ppm}) \\
\text { from } \\
210 \mathrm{~Pb}\end{array}$ & $\begin{array}{c}\text { Th }(\mathrm{ppm}) \\
\text { From } \\
208 \mathrm{Tl} \\
212 \mathrm{~Pb} \\
228 \mathrm{Ac}\end{array}$ & K \% & Field Code \\
\hline WLL482 & 1.283 & $4.29 \pm 0.33$ & $3.25 \pm 0.21$ & $2.84 \pm 0.26$ & $11.93 \pm 0.16$ & $1.38 \pm 0.03$ & WLL482 \\
\hline WLL499 & 1.341 & $2.56 \pm 0.20$ & $2.18 \pm 0.14$ & $1.86 \pm 0.17$ & $7.56 \pm 0.10$ & $1.24 \pm 0.03$ & WLL499 \\
\hline WLL855 & 32.1 & $3.83 \pm 0.37$ & $3.45 \pm 0.20$ & $3.84 \pm 0.29$ & $14.73 \pm 0.19$ & $2.87 \pm 0.06$ & DOG684 \\
\hline WLL856 & 23.7 & $3.15 \pm 0.35$ & $2.83 \pm 0.19$ & $2.87 \pm 0.27$ & $10.23 \pm 0.15$ & $2.30 \pm 0.05$ & DOG552 \\
\hline WLL857 & 24.1 & $3.15 \pm 0.36$ & $2.67 \pm 0.19$ & $2.47 \pm 0.26$ & $10.33 \pm 0.16$ & $2.35 \pm 0.05$ & DOG484 \\
\hline WLL858 & 24.7 & $3.62 \pm 0.35$ & $3.32 \pm 0.19$ & $3.28 \pm 0.26$ & $11.46 \pm 0.16$ & $1.86 \pm 0.04$ & DOG420 \\
\hline WLL859 & 27.5 & $3.08 \pm 0.29$ & $2.74 \pm 0.16$ & $3.33 \pm 0.23$ & $11.03 \pm 0.14$ & $2.15 \pm 0.05$ & DOG295 \\
\hline WLL860 & 29.8 & $3.10 \pm 0.38$ & $2.62 \pm 0.21$ & $2.40 \pm 0.29$ & $10.23 \pm 0.16$ & $2.19 \pm 0.05$ & DOG155 \\
\hline WLL861 & 24.7 & $2.26 \pm 0.26$ & $2.83 \pm 0.22$ & $2.56 \pm 0.16$ & $10.06 \pm 0.14$ & $2.22 \pm 0.05$ & DOG110 \\
\hline WLL879 & 24.7 & $3.27 \pm 0.29$ & $3.28 \pm 0.18$ & $3.57 \pm 0.25$ & $12.37 \pm 0.15$ & $1.75 \pm 0.04$ & COW125 \\
\hline WLL880 & 27.1 & $3.48 \pm 0.36$ & $3.34 \pm 0.22$ & $3.43 \pm 0.30$ & $12.39 \pm 0.18$ & $1.75 \pm 0.04$ & COW210 \\
\hline WLL881 & 36.4 & $3.96 \pm 0.31$ & $3.36 \pm 0.19$ & $3.96 \pm 0.26$ & $13.28 \pm 0.16$ & $0.87 \pm 0.02$ & COW293 \\
\hline WLL882 & 33.6 & $3.34 \pm 0.35$ & $3.13 \pm 0.21$ & $3.42 \pm 0.28$ & $11.32 \pm 0.17$ & $1.40 \pm 0.03$ & $\begin{array}{c}\text { VERGE } \\
327\end{array}$ \\
\hline WLL862 & 22.8 & $4.00 \pm 0.37$ & $3.45 \pm 0.20$ & $3.60 \pm 0.28$ & $13.35 \pm 0.18$ & $2.71 \pm 0.06$ & KL-1OSL \\
\hline WLL863 & 22.8 & $3.84 \pm 0.42$ & $3.17 \pm 0.22$ & $2.41 \pm 0.28$ & $12.88 \pm 0.19$ & $1.95 \pm 0.05$ & KL-2OSL \\
\hline WLL864 & 17.5 & $2.54 \pm 0.35$ & $2.46 \pm 0.19$ & $2.27 \pm 0.26$ & $8.42 \pm 0.14$ & $1.90 \pm 0.05$ & KL-3OSL \\
\hline WLL865 & 23.6 & $3.67 \pm 0.44$ & $3.16 \pm 0.24$ & $2.42 \pm 0.31$ & $13.06 \pm 0.20$ & $1.98 \pm 0.05$ & KL-4OSL \\
\hline WLL866* & 19.0 & $3.44 \pm 0.30$ & $2.92 \pm 0.16$ & $2.12 \pm 0.19$ & $11.31 \pm 0.14$ & $2.22 \pm 0.05$ & KL-5OSL \\
\hline WLL816* & 14.5 & $2.68 \pm 0.28$ & $2.25 \pm 0.15$ & $0.96 \pm 0.18$ & $8.74 \pm 0.13$ & $1.83 \pm 0.04$ & NWI 1A \\
\hline WLL817* & 23.3 & $3.12 \pm 0.32$ & $2.51 \pm 0.18$ & $1.92 \pm 0.21$ & $10.14 \pm 0.15$ & $1.29 \pm 0.03$ & NWI 2 \\
\hline WLL818* & 18.9 & $2.58 \pm 0.36$ & $2.38 \pm 0.21$ & $1.23 \pm 0.25$ & $10.58 \pm 0.17$ & $1.90 \pm 0.05$ & PAL3A \\
\hline
\end{tabular}




\begin{tabular}{|c|c|c|c|c|c|c|c|}
\hline WLL819* & 20.0 & $3.12 \pm 0.40$ & $2.48 \pm 0.22$ & $2.24 \pm 0.28$ & $10.79 \pm 0.18$ & $2.04 \pm 0.05$ & PAL3B \\
\hline WLL820* & 22.7 & $2.47 \pm 0.28$ & $2.41 \pm 0.17$ & $1.21 \pm 0.19$ & $9.89 \pm 0.14$ & $1.82 \pm 0.04$ & PAL4 \\
\hline WLL840 & 12.3 & $2.20 \pm 0.31$ & $1.53 \pm 0.17$ & $1.59 \pm 0.24$ & $7.87 \pm 0.13$ & $1.94 \pm 0.05$ & WHAN01 \\
\hline WLL841 & 11.3 & $1.54 \pm 0.15$ & $1.76 \pm 0.09$ & $1.73 \pm 0.13$ & $7.55 \pm 0.09$ & $1.88 \pm 0.04$ & WHAN02 \\
\hline WLL847* & 14.2 & $2.61 \pm 0.34$ & $2.35 \pm 0.19$ & $1.63 \pm 0.24$ & $8.85 \pm 0.15$ & $1.80 \pm 0.04$ & NWI 1B \\
\hline WLL848 & 13.3 & $2.36 \pm 0.35$ & $2.13 \pm 0.19$ & $2.19 \pm 0.27$ & $9.92 \pm 0.16$ & $2.29 \pm 0.05$ & WSHP01 \\
\hline WLL849 & 14.1 & $2.50 \pm 0.32$ & $2.23 \pm 0.18$ & $2.25 \pm 0.25$ & $9.43 \pm 0.15$ & $2.16 \pm 0.05$ & WSHP02 \\
\hline WLL850 & 16.4 & $2.52 \pm 0.36$ & $2.17 \pm 0.20$ & $2.28 \pm 0.28$ & $9.27 \pm 0.16$ & $2.10 \pm 0.05$ & WSHP03 \\
\hline WLL851 & 23.4 & $3.18 \pm 0.31$ & $2.65 \pm 0.17$ & $2.58 \pm 0.22$ & $10.48 \pm 0.15$ & $1.37 \pm 0.03$ & WSHP04 \\
\hline WLL875 & 22.1 & $1.92 \pm 0.23$ & $1.80 \pm 0.13$ & $1.97 \pm 0.18$ & $6.98 \pm 0.11$ & $1.79 \pm 0.04$ & GC-1a \\
\hline WLL876 & 23.7 & $2.09 \pm 0.24$ & $1.94 \pm 0.13$ & $2.08 \pm 0.19$ & $8.11 \pm 0.12$ & $2.04 \pm 0.05$ & Wpapa 1 \\
\hline WLL877 & 16.8 & $1.89 \pm 0.14$ & $1.77 \pm 0.09$ & $1.75 \pm 0.12$ & $7.74 \pm 0.09$ & $1.93 \pm 0.04$ & Wpapa 2 \\
\hline WLL1038 & 14.9 & $2.38 \pm 0.16$ & $1.98 \pm 0.09$ & $1.48 \pm 0.12$ & $7.99 \pm 0.09$ & $1.69 \pm 0.03$ & BARHD02 \\
\hline WLL1039 & 16.5 & $2.07 \pm 0.21$ & $1.87 \pm 0.13$ & $1.72 \pm 0.17$ & $7.72 \pm 0.11$ & $1.48 \pm 0.03$ & BARHD03 \\
\hline WLL933 & 10.23 & $1.63 \pm 0.20$ & $1.73 \pm 0.12$ & $1.32 \pm 0.16$ & $6.91 \pm 0.10$ & $1.16 \pm 0.03$ & BAR01 \\
\hline WLL867 & 25.2 & $3.06 \pm 0.41$ & $2.73 \pm 0.23$ & $2.32 \pm 0.30$ & $11.64 \pm 0.19$ & $1.85 \pm 0.05$ & TP01 \\
\hline WLL868 & 23.6 & $3.65 \pm 0.40$ & $2.62 \pm 0.20$ & $2.41 \pm 0.27$ & $10.96 \pm 0.17$ & $1.64 \pm 0.04$ & TP02 \\
\hline & 31.2 & $3.70 \pm 0.42$ & $2.68 \pm 0.23$ & $1.79 \pm 0.27$ & $13.50 \pm 0.20$ & $1.68 \pm 0.04$ & TP03 \\
\hline & & & & & & & \\
\hline & & & & & & & \\
\hline
\end{tabular}

* U decay chains were in disequilibrium 
Table A.3 a-Values, Dose Rates, Equivalent Doses and Luminescence Dating Ages

\begin{tabular}{|c|c|c|c|c|c|}
\hline $\begin{array}{c}\text { Laboratory } \\
\text { Code }\end{array}$ & a-value & De (Gy) & $\begin{array}{l}\text { Dose rate } \\
\text { (Gy/ka) }\end{array}$ & $\begin{array}{l}\text { OSL age }(\mathrm{ka}) \\
(1 \sigma)\end{array}$ & Field Code \\
\hline *WLL482 & $0.071 \pm 0.013$ & $323.7 \pm 13.9$ & $\begin{array}{c}9.90 \pm 0.29 \\
(3.34 \pm 0.29)\end{array}$ & $\begin{array}{c}95.4 \pm 9.4 \\
(97.0 \pm 9.4)\end{array}$ & WLL482 \\
\hline WLL499 & $0.088 \pm 0.008$ & $21.6 \pm 0.22$ & $2.54 \pm 0.22$ & $8.50 \pm 0.86$ & WLL499 \\
\hline WLL855 & $0.08 \pm 0.01$ & $\begin{array}{c}351.0 \pm 3.6 \\
\# 243.0 \pm 22.0\end{array}$ & $4.72 \pm 0.35$ & $\begin{array}{c}74.3 \pm 5.5 \\
\# 51.4 \pm 6.0\end{array}$ & DOG684 \\
\hline WLL856 & $0.018 \pm 0.003$ & $\begin{array}{c}198.8 \pm 28.4 \\
\# 248.0 \pm 15.6\end{array}$ & $3.29 \pm 0.10$ & $\begin{array}{c}60.3 \pm 8.8 \\
\# 75.3 \pm 5.3\end{array}$ & DOG552 \\
\hline WLL857 & $0.040 \pm 0.004$ & $\begin{array}{c}304.3 \pm 44.75 \\
\# 176.5 \pm 15.21\end{array}$ & $3.50 \pm 0.10$ & $\begin{array}{l}87.0 \pm 13.0 \\
\# 50.5 \pm 4.6\end{array}$ & DOG484 \\
\hline WLL858 & $0.09 \pm 0.01$ & $148.16 \pm 4.55$ & $3.87 \pm 0.11$ & $38.3 \pm 1.6$ & DOG420 \\
\hline WLL859 & $0.060 \pm 0.003$ & $76.18 \pm 4.09$ & $3.59 \pm 0.12$ & $21.2 \pm 1.3$ & DOG295 \\
\hline WLL860 & $0.07 \pm 0.01$ & $70.58 \pm 3.71$ & $3.49 \pm 0.14$ & $20.3 \pm 1.3$ & DOG155 \\
\hline WLL861 & $0.047 \pm 0.004$ & $59.36 \pm 4.47$ & $3.45 \pm 0.08$ & $17.2 \pm 1.4$ & DOG110 \\
\hline WLL879 & $0.07 \pm 0.01$ & $91.73 \pm 3.98$ & $3.70 \pm 0.16$ & $24.8 \pm 1.5$ & COW125 \\
\hline WLL880 & $0.09 \pm 0.01$ & $147.74 \pm 9.04$ & $3.83 \pm 0.17$ & $38.5 \pm 2.9$ & COW210 \\
\hline WLL881 & $0.06 \pm 0.01$ & $186.44 \pm 16.39$ & $2.67 \pm 0.14$ & $69.8 \pm 7.2$ & COW293 \\
\hline WLL882 & $0.04 \pm 0.02$ & $\# 253.38 \pm 19.16$ & $2.72 \pm 0.21$ & $\# 93.2 \pm 10.0$ & VERGE 327 \\
\hline WLL862 & $\wedge^{\wedge} 0.05 \pm 0.03$ & $389.58 \pm 28.33$ & $4.41 \pm 0.38$ & $88.3 \pm 9.9$ & KL-1OSL \\
\hline WLL863 & $0.05 \pm 0.03$ & $81.0 \pm 2.1$ & $3.74 \pm 0.15$ & $21.7 \pm 1.0$ & KL-2OSL \\
\hline WLL864 & $0.040 \pm 0.022$ & $40.22 \pm 1.53$ & $3.20 \pm 0.09$ & $12.6 \pm 0.6$ & KL-3OSL \\
\hline WLL865 & $0.08 \pm 0.01$ & $45.50 \pm 3.26$ & $4.07 \pm 0.16$ & $11.2 \pm 0.9$ & KL-4OSL \\
\hline WLL866 & $0.07 \pm 0.01$ & $68.44 \pm 2.85$ & $4.09 \pm 0.15$ & $16.7 \pm 0.9$ & KL-5OSL \\
\hline WLL816 & $0.04 \pm 0.02$ & & & & NWI 1A \\
\hline WLL817 & $0.08 \pm 0.02$ & $119.23 \pm 4.38$ & $3.01 \pm 0.23$ & $39.5 \pm 3.3$ & NWI 2 \\
\hline WLL818 & $\wedge^{\wedge} 0.04 \pm 0.02$ & $286.26 \pm 10.76$ & $3.29 \pm 0.20$ & $87.1 \pm 6.3$ & PAL3A \\
\hline
\end{tabular}




\begin{tabular}{|c|c|c|c|c|c|}
\hline WLL819 & $\wedge 0.04 \pm 0.02$ & $433.00 \pm 21.65$ & $3.42 \pm 0.21$ & $126.7 \pm 10.0$ & PAL3B \\
\hline & & $\# 300.00 \pm 10.27$ & & $\# 87.8 \pm 6.1$ & \\
\hline WLL820 & $0.07 \pm 0.01$ & $284.24 \pm 9.16$ & $3.31 \pm 0.12$ & $86.0 \pm 4.2$ & PAL4 \\
\hline WLL840 & $0.07 \pm 0.01$ & $211.89 \pm 4.73$ & $3.13 \pm 0.09$ & $68.0 \pm 2.5$ & WHAN01 \\
\hline WLL841 & $0.04 \pm 0.01$ & $274.27 \pm 11.27$ & $2.95 \pm 0.08$ & $93.0 \pm 4.5$ & WHAN02 \\
\hline WLL847 & $\wedge 0.04 \pm 0.02$ & $358.33 \pm 21.50$ & $3.12 \pm 0.20$ & $114.5 \pm 10.0$ & NWI 1B \\
\hline WLL848 & $0.047 \pm 0.003$ & $234.35 \pm 21.50$ & $3.69 \pm 0.09$ & $63.5 \pm 6.0$ & WSHP01 \\
\hline WLL849 & $0.092 \pm 0.004$ & $269.21 \pm 33.73$ & $3.93 \pm 0.10$ & $68.6 \pm 8.8$ & WSHP02 \\
\hline WLL850 & $0.082 \pm 0.004$ & $206.69 \pm 5.10$ & $3.69 \pm 0.12$ & $56.1 \pm 2.3$ & WSHP03 \\
\hline WLL851 & $0.065 \pm 0.007$ & $120.59 \pm 4.50$ & $3.02 \pm 0.10$ & $39.9 \pm 2.0$ & WSHP04 \\
\hline WLL875 & ${ }^{\wedge} 0.04 \pm 0.02$ & $261.47 \pm 28.3$ & $2.60 \pm 0.15$ & $100.7 \pm 12.4$ & GC-1a \\
\hline WLL876 & $\wedge^{\wedge} 0.04 \pm 0.02$ & ${ }^{\#} 609.83 \pm 34.38$ & $2.95 \pm 0.17$ & ${ }^{{ }^{2}} 206.9 \pm 16.6$ & Wpapa 1 \\
\hline WLL877 & $\wedge^{\wedge} 0.04 \pm 0.02$ & ${ }^{\#} 583.92 \pm 44.92$ & $2.94 \pm 0.15$ & $\# 198.9 \pm 18.3$ & Wpapa 2 \\
\hline WLL1038 & $\wedge 0.05 \pm 0.03$ & $477.51 \pm 56.50$ & $2.96 \pm 0.26$ & $161.3 \pm 23.9$ & BARHD02 \\
\hline WLL1039 & $\wedge^{\wedge} 0.05 \pm 0.03$ & $391.32 \pm 14.77$ & $2.68 \pm 0.25$ & $145.8 \pm 14.5$ & BARHD03 \\
\hline WLL933 & ${ }^{\wedge} 0.05 \pm 0.03$ & $134.51 \pm 7.41$ & $2.42 \pm 0.22$ & $55.5 \pm 8.7$ & BAR01 \\
\hline WLL867 & ${ }^{\wedge} 0.05 \pm 0.03$ & $367.25 \pm 12.50$ & $3.34 \pm 0.16$ & $110.0 \pm 10.8$ & TP01 \\
\hline WLL868 & ${ }^{\wedge} 0.05 \pm 0.03$ & $394.17 \pm 39.42$ & $3.13 \pm 0.29$ & $125.9 \pm 17.1$ & TP02 \\
\hline WLL869 & $0.06 \pm 0.01$ & $62.37 \pm 2.09$ & $3.28 \pm 0.15$ & $19.0 \pm 1.1$ & TP03 \\
\hline
\end{tabular}

$\wedge$ a-value was estimated as these samples close to saturation

* This sample showed radioactive disequilibrium and the given age was corrected accordingly. As the level of disequilibrium over time is unknown, the age is only a best estimate. Uncorrected dose rate and age are shown in parenthesis.

\# Ages obtained by SAR method 


\section{Discussion}

From Table A.2, it can be observed that WLL816 through to WLL820 as well as WLL847 display disequilibrium in their uranium decay chains. This is probably the result of radionuclide mobility during their burial time. An adjustment of the uranium content slightly affects age. However if the uncertainty of the calculated age is taken into account, the effect of the adjustment is negligible.

The age of WLL816 in Table A.3 is blank as the dataset was too scattered (Fig. A.5) and therefore unusable. Further experimentation and measurements are required. The age of WLL819 is $126.7 \pm$ $10.0 \mathrm{ka}$ as calculated using the MAAD method. As the age is quite different from the test measurement, a cross check was necessary. The SAR method was applied to WLL819 after the MAAD method, and the age obtained is $87.8 \pm 6.1 \mathrm{ka}$. The datasets obtained from both methods produce clear results, and we were unable to find the reasons for the age difference between the two techniques.

When examining the age of WLL841 (Fig A.6), it is found to be more reliable than the age of WLL840 (Fig. A.7) based on measurement data. Therefore we prefer to use the age of WLL841 rather than the age of WLL840 and are able to do so as they are in the same unit.

In Table A.3, the ages of WLL855-WLL857 vary in the results from both the MAAD and SAR methods (e.g. Fig. A.8; Fig. A.9). We repeated the measurements for these samples using the two methods, yet we could not obtain any clearer results as the samples responded to the luminescence poorly. The variety of ages may indicate that these samples were partially bleached before deposition. Another possible reason is that they were soaked in water for so long that it could have caused their mineral behaviour to change.

The age shown in Table A.3 for WLL875 is the best estimate we can provide as the dataset was scattered.

The ages of WLL876 and WLL877 (Fig. A.10) were obtained through the SAR method. The MAAD method was originally employed for sample WLL876 (Fig. A.11), however the results were inconclusive. The dataset produced by SAR is reliable and as a result we are confident in the age obtained for the WLL876 sample using this method. Because of the similarities in composition between samples WLL877 and WLL876, only the SAR method was applied to WLL877.

In Table A.3, the age of WLL882 was obtained by the SAR method because the MAAD method gave an inconclusive dataset. 


\section{References}

Adamiec, G. and M. Aitken (1998). Dose- rate conversion factors: update. Ancient TL, 16, no.2, 37-50.

Murry, A.S. \& A.G. Wintle (2000). Luminescence dating of quartz using an improved single aliquot regenerative dose protocol. Radiat. Meas. 32 57-73.

Prescott, J.R. \& J.T. Hutton (1994). Cosmic ray contributions to dose rates for luminescence and ESR dating: Large depths and long-term time variations. Radiat. Meas. 23, nos. 2/3, 497-500. 


\section{Appendix B}

Stratigraphic Logs of Fluvial Terraces

COW auger site

E 2682710, N 6010280

Emerald Hill Terrace Tread EH-T5

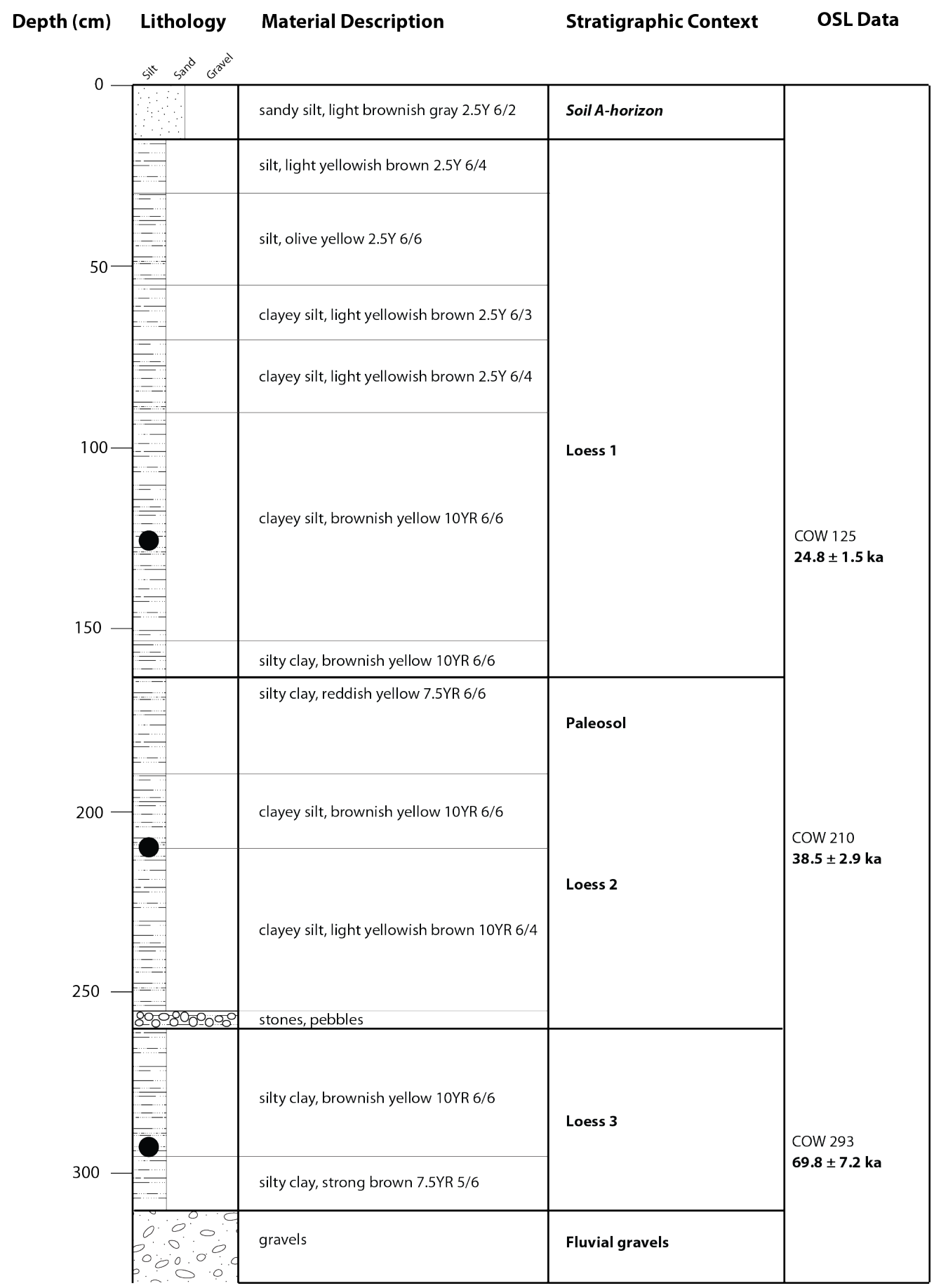


VERGE auger site

E 2686780, N 6010200

Emerald Hill Terrace Tread EH-T5

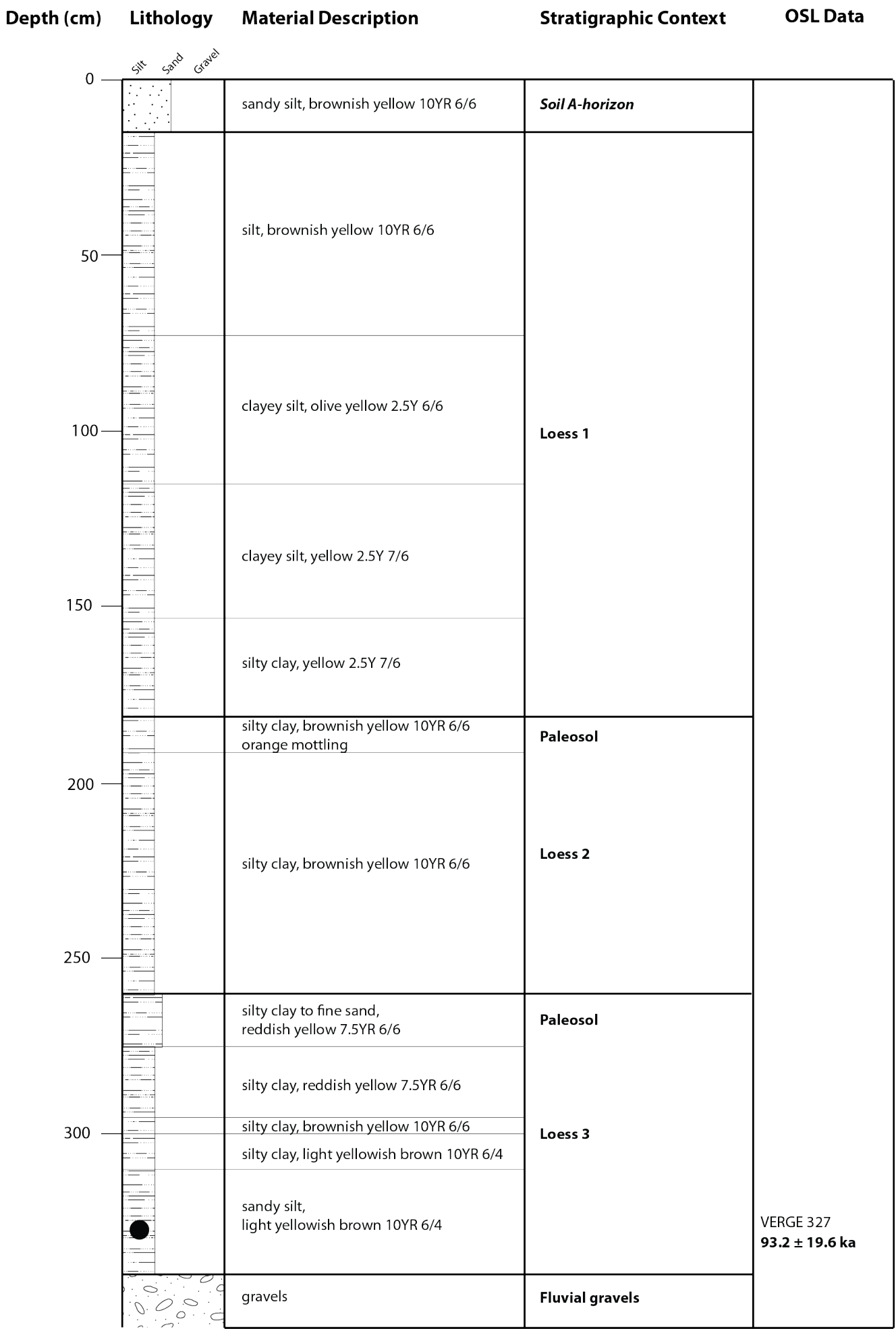


DOG auger site

E 2686937, N 6009885

Emerald Hill Terrace Tread EH-T4

Depth (cm) Lithology Material Description

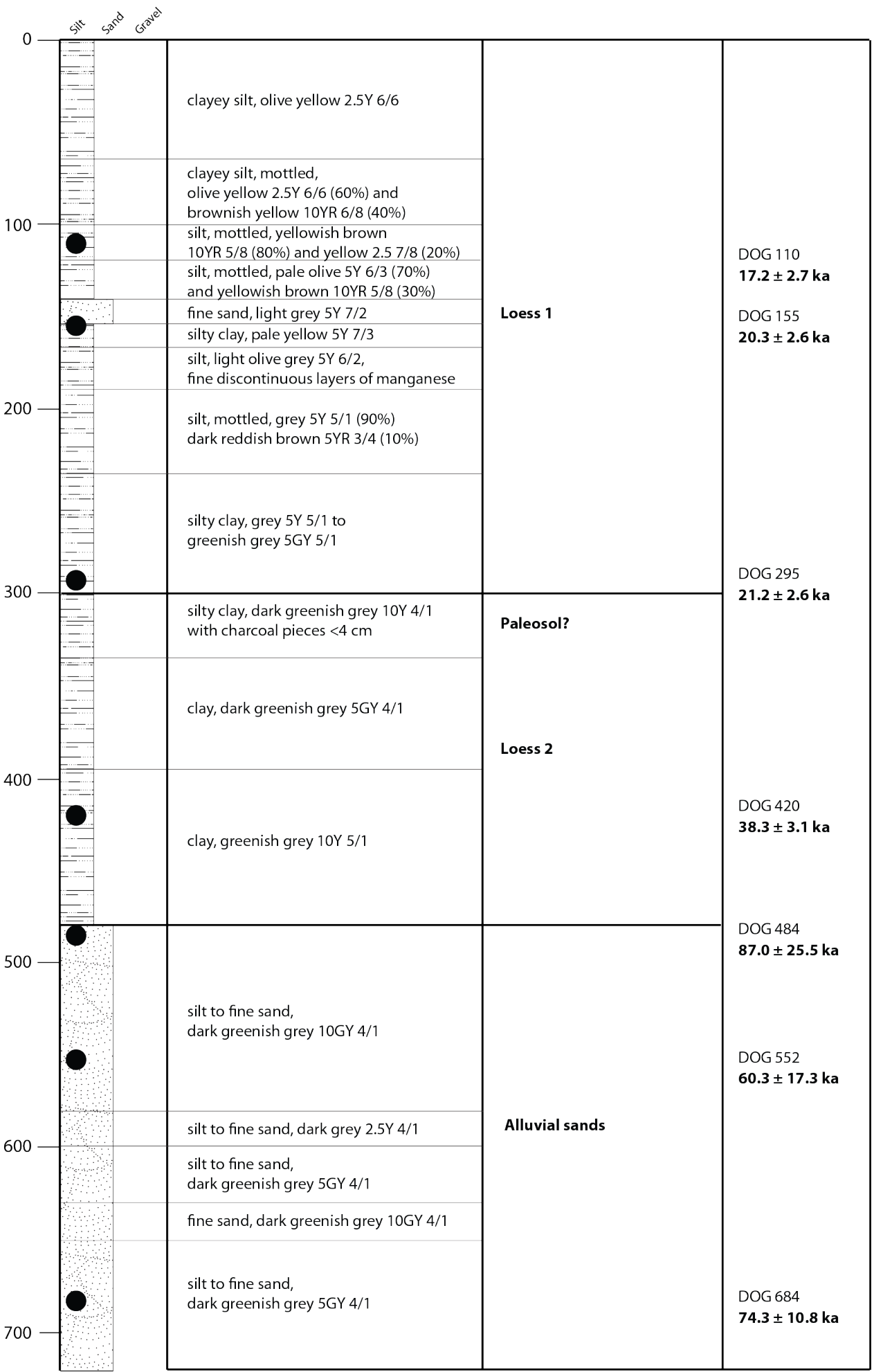


WLL482 sample site

E 2686240, N 6009190

Brown Owl

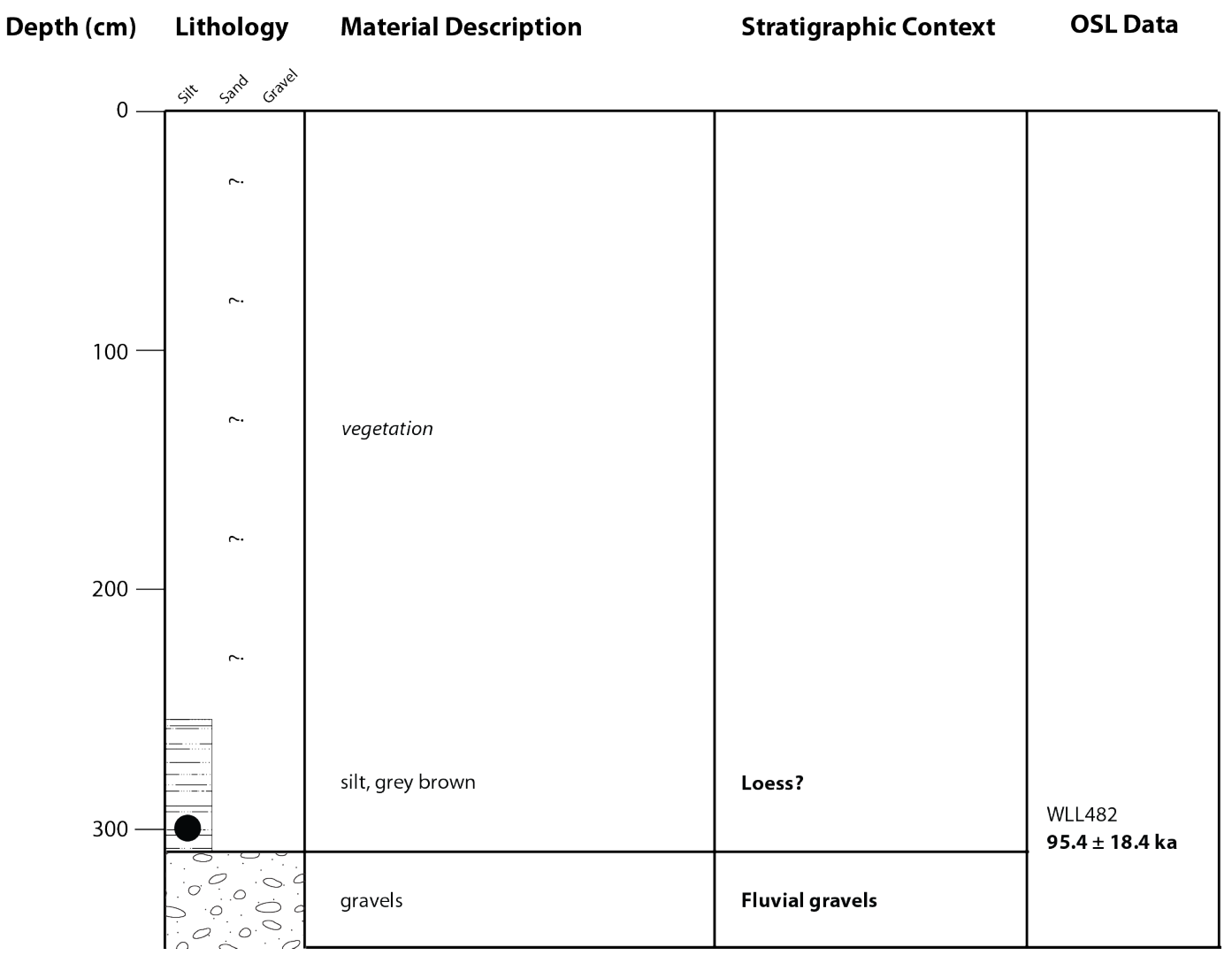

WLL499 auger site

E 2687320, N 6010110

Emerald Hill Terrace Tread EH-T3

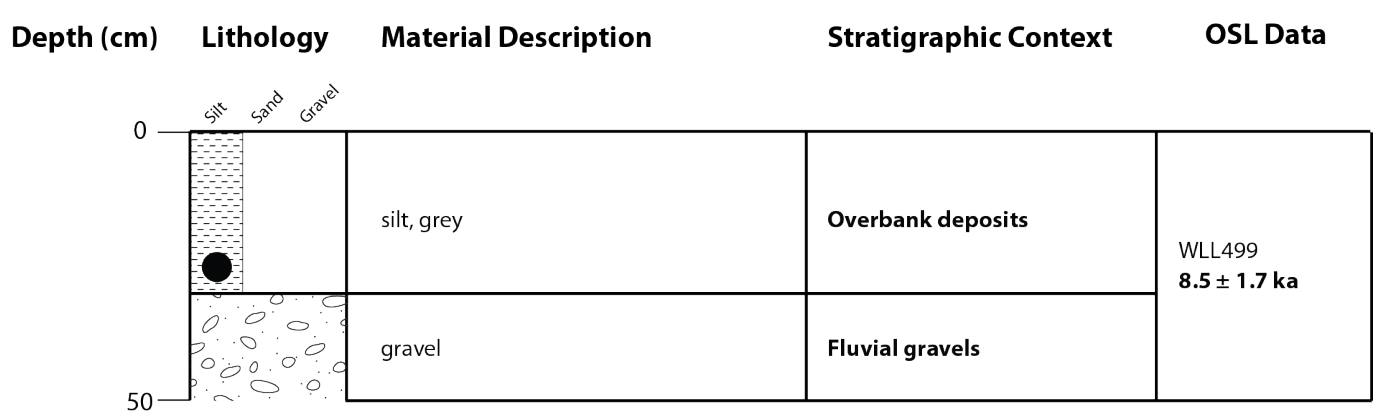


KL 2OSL sample site

E 2690184, N 6012026

Kaitoke Lakes Terrace Tread KL-T4

\section{Depth (cm) Lithology Material Description}

Stratigraphic Context

OSL Data

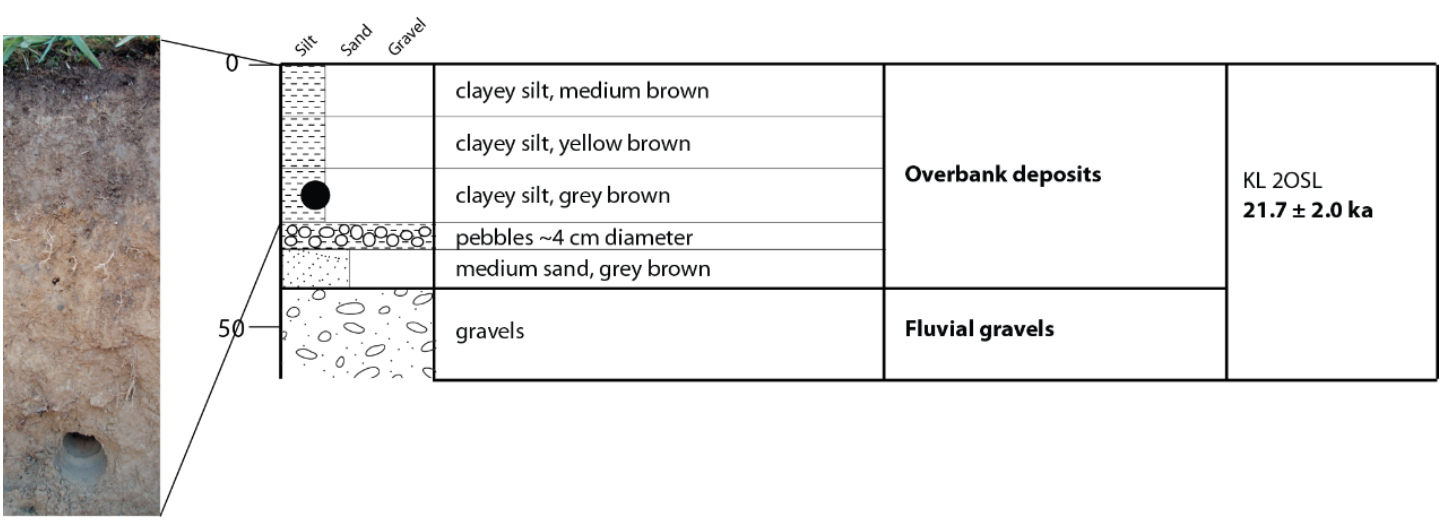

KL 3OSL sample site

E 2690393, N 6012048

Kaitoke Lakes Terrace Tread KL-T3

Depth (cm) Lithology Material Description

Stratigraphic Context

OSL Data

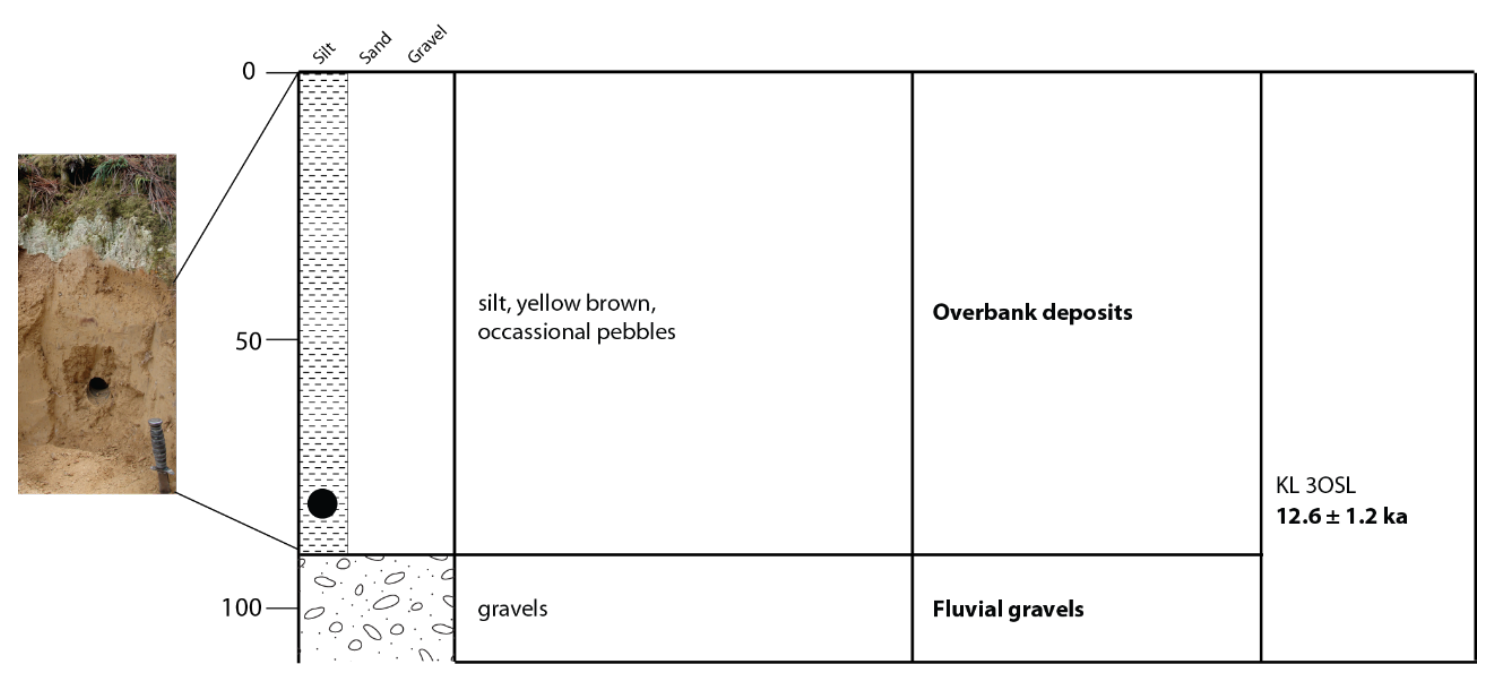


$\mathrm{KL}$ 4OSL sample site

E 2690176, N?

Kaitoke Lakes Terrace Tread KL-T3

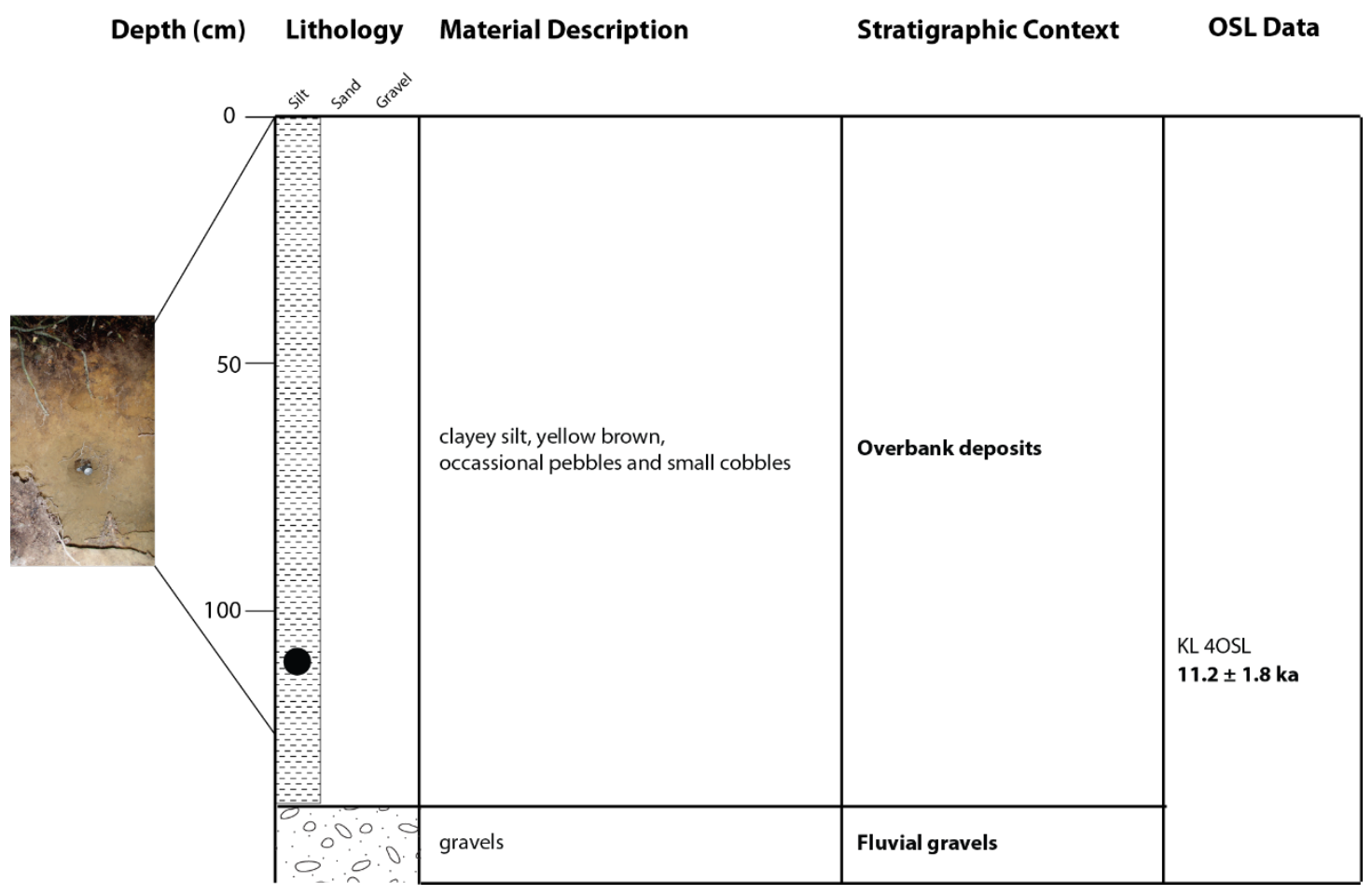

KL 5OSL sample site

E 2690180, N 6011838

Kaitoke Lakes Terrace Tread KL-T3

Depth $(\mathrm{cm}) \quad$ Lithology Material Description

Stratigraphic Context

OSL Data

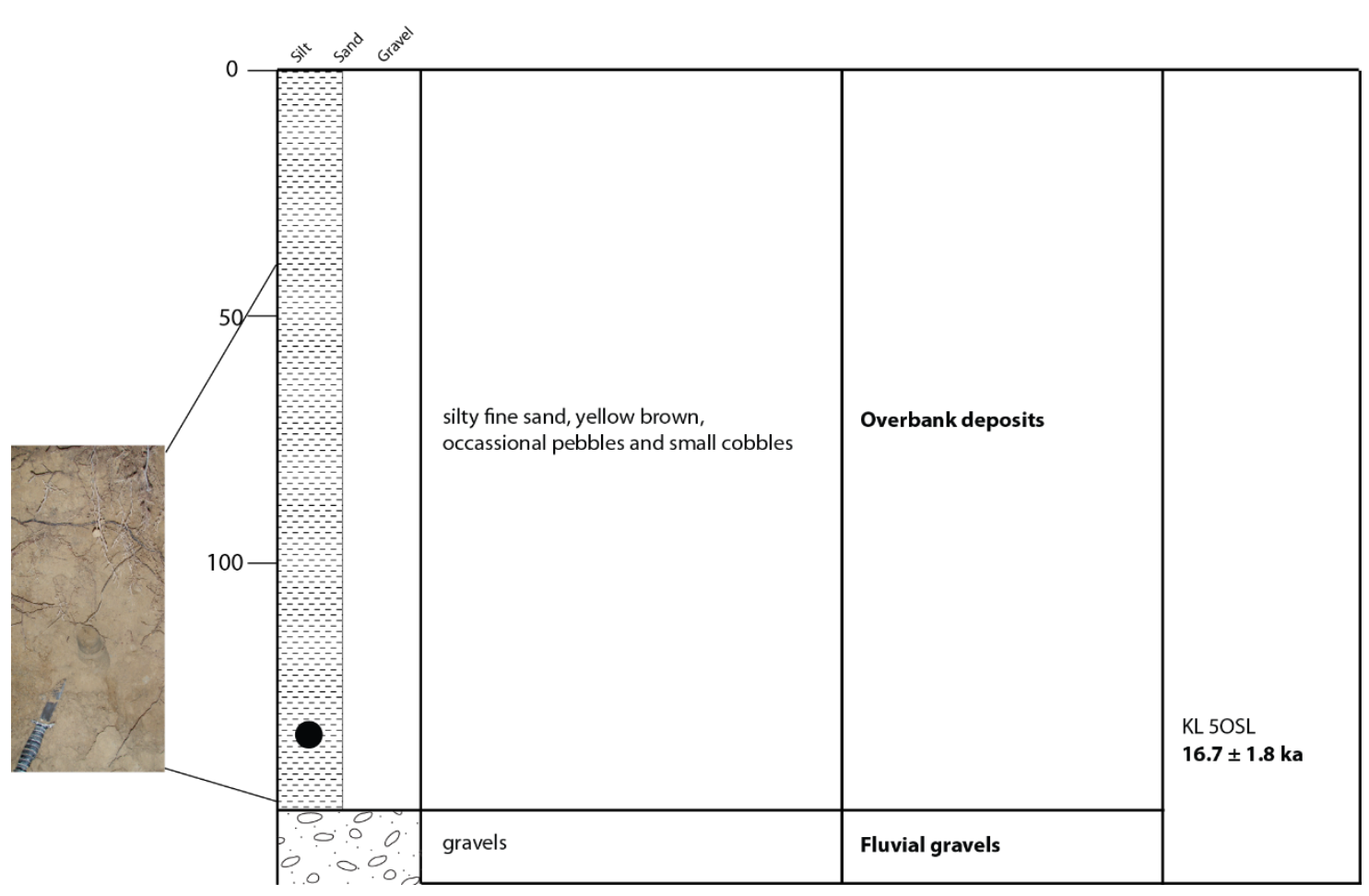




\section{Appendix C}

Terrace Age Estimation Using Conditional Probabilities and Bayesian Statistics

Text taken directly from Appendix of:

Ninis, D., Little, T.A., Van Dissen, R.J., Litchfield, N.J., Smith, E.G., Wang, N., Rieser, U. and Henderson, C.M., 2013. Slip rate on the Wellington fault, New Zealand, during the late Quaternary: Evidence for variable slip during the Holocene. Bulletin of the Seismological Society of America, 103(1), pp.559-579.

Written by Euan Smith

Victoria University of Wellington

The inferred ages for terraces EH-T3 and EH-T1a are $t_{3}=8.5 \pm 1.7 \mathrm{ka}$ and $t_{1}=9.6 \pm 1.6 \mathrm{ka}$ respectively; in particular, the measured age of the younger EH-T1a is older than that of EH-T3. In addition, there is a terrace, EH-T2, of intermediate age $t_{2}$ between EH-T3 and EH-T1a. The objective is to calculate 'best' ages for EH-T3, EH-T2 and EH-T1a, with uncertainties, making use of the information that:

$$
t_{3} \geq t_{2} \geq t_{1}
$$

Bayes' theorem provides a way to incorporate such information into the calculation of probability distributions, and it has been used in earthquake hazard calculations for some time (e.g. Campbell, 1982).

First we assume that the probability distributions for the true ages of EH-T3 and EH-T1a are Gaussian, with means of $m_{3}=8.5 \mathrm{ka}$ and $m_{1}=9.6 \mathrm{ka}$ and standard deviations of $s_{3}=1.7 / 2 \mathrm{ka}$ and $s_{1}$ $=1.6 / 2 \mathrm{ka}$ respectively. These then are the prior distributions for the ages of these two terraces (Campbell, 1982).

Since the estimates of ages are independent, the joint probability density $g_{13}\left(t_{1}, t_{3}\right)$ for the ages $t_{3}$ and $t_{1}$ of EH-T3 and EH-T1a is the product of their individual Gaussian densities, giving a bivariate Gaussian distribution:

$$
g_{13}\left(t_{1}, t_{3}\right)=\left(1 / 2 \pi s_{1} s_{3}\right) \exp \left\{-(1 / 2)\left[\left(t_{1}-m_{1}\right)^{2} / s_{1}{ }^{2}+\left(t_{3}-m_{3}\right)^{2} / s_{3}^{2}\right]\right\}
$$

To apply the constraint A1, we use Bayes' theorem to write the conditional joint probability of $t_{1}$ and $t_{3}$ given that $t_{3} \geq t_{1}$ as:

$$
f_{13}\left(t_{1}, t_{3} \mid t_{3} \geq t_{1}\right) \propto f_{p}\left(t_{3} \geq t_{1} \mid t_{1}, t_{3}\right) g_{13}\left(t_{1}, t_{3}\right)
$$


(e.g. Congdon, 2001, p15), where $f_{p}\left(t_{3} \geq t_{1} \mid t_{1}, t_{3}\right)$ is the prior conditional probability distribution for $t_{3} \geq t_{1}$ given $t_{1}$ and $t_{3}$, which is taken to be 1 in the half plane $t_{3} \geq t_{1}$ and zero elsewhere. It is convenient to represent this functionally using an Indicator Function I(A), defined:

$$
\begin{aligned}
\mathrm{I}(\mathrm{A}) & =1 \text { if } \mathrm{A} \text { is true } \\
& =0 \text { otherwise }
\end{aligned}
$$

Thus:

$$
\begin{aligned}
& f_{13}\left(t_{1}, t_{3} \mid t_{3} \geq t_{1}\right)= \\
& C_{n} I\left(t_{3} \geq t_{1}\right)\left(1 / 2 \pi s_{1} s_{3}\right) \exp \left\{-(1 / 2)\left[\left(t_{1}-m_{1}\right)^{2} / s_{1}{ }^{2}+\left(t_{3}-m_{3}\right)^{2} / s_{3}{ }^{2}\right]\right\}
\end{aligned}
$$

where $C_{n}$ is a normalising constant determined by numerically integrating the right hand side of equation $\mathrm{A} 3$ over the half-plane $t_{3} \geq t_{1}$ (figure A1). Marginal probability density functions $f_{1}\left(t_{1}\right)$ and $f_{3}\left(t_{3}\right)$ for $t_{1}$ and $t_{3}$ can then be obtained by integrating the other variable out of $g_{13}$; e.g.

$$
f_{1}\left(t_{1}\right)=\int_{\mathrm{t}_{1}}^{\infty} C_{\mathrm{n}}\left(1 / 2 \pi s_{1} s_{3}\right) \exp \left\{-(1 / 2)\left[\left(t_{1}-m_{1}\right)^{2} /{s_{1}}^{2}+\left(t_{3}-m_{3}\right)^{2} / s_{3}{ }^{2}\right]\right\} d t_{3}
$$

The means and standard deviations of these distributions yield ages and standard deviations for EH-T3 and EH-T1a of $9.42 \pm 1.3 \mathrm{ka}$ and $8.80 \pm 1.3$ ka respectively (uncertainties both $2 \sigma$ ).

An estimate of the age, $t_{2}$, of the intermediate terrace EH-T2 can now be obtained, conditional on its age being between the ages of EH-T3 and EH-T1a. For the probability distribution of $t_{2}$ given $t_{3} \geq t_{2} \geq t_{1}$ :

$$
f_{2}\left(t_{2} \mid t_{1}, t_{3}\right) \propto f_{2 p}\left(t_{2}\right) f_{13}\left(t_{1}, t_{3} \mid t_{3} \geq t_{1}\right)
$$

where $f_{2 p}\left(t_{2}\right)$ is the prior probability density for $t_{2}$. In the absence of any information about the placement of $t_{2}$ between $t_{1}$ and $t_{3}$, it is common to take the prior to be a uniform distribution, sometimes called a 'noninformative prior'. That is:

$$
\begin{aligned}
f_{2 p}\left(t_{2}\right) & =1 /\left(t_{3}-t_{1}\right) \quad \text { for } t_{3} \geq t_{2} \geq t_{1} \\
& =0 \text { otherwise }
\end{aligned}
$$

or using an indicator function:

$$
f_{2 p}\left(t_{2}\right)=1 /\left(t_{3}-t_{1}\right) I\left(t_{3} \geq t_{2} \geq t_{1}\right)
$$

Then:

$$
f_{2}\left(t_{2} \mid t_{1}, t_{3}\right)=D_{n} /\left(t_{3}-t_{1}\right) I\left(t_{3} \geq t_{2} \geq t_{1}\right) f_{13}\left(t_{1}, t_{3} \mid t_{3} \geq t_{1}\right) \quad \text { for } t_{3} \geq t_{2} \geq t_{1}
$$

where $D_{n}$ is another normalising constant obtained by integration as before. 
The marginal probability density function $f_{2}\left(t_{2}\right)$ may be obtained by numerical integration of A8:

$$
f_{2}\left(t_{2}\right)=\int_{-\infty}^{\infty}\left\{\int_{t 1}^{\infty} D n /\left(t_{3}-t_{1}\right) I\left(t_{3} \geq t_{2} \geq t_{1}\right) f_{13}\left(t_{1}, t_{3} \mid t_{3} \geq t_{1}\right) d t_{3}\right\} d t_{1}
$$

which gives zero contributions to $f_{2}\left(t_{2}\right)$ from $t_{1}, t_{3}$ pairs where $t_{2}$ is outside the interval $\left(t_{1}, t_{3}\right) . f_{2}\left(t_{2}\right)$ calculated in this way gives a mean age for EH-T2 of $9.1 \pm 1.3 \mathrm{ka}(2 \sigma)$.

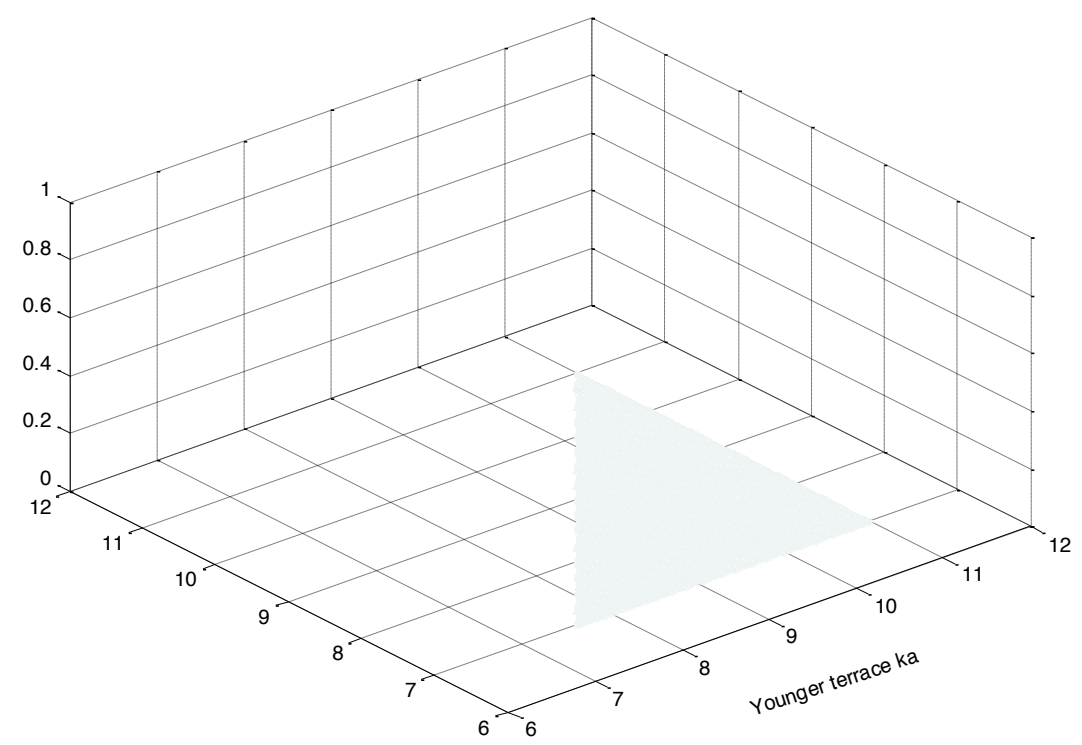

Figure C.1. Joint probability density function $f_{13}\left(t_{1}, t_{3} \mid t_{3} \geq t_{1}\right)$ for the ages $t_{1}$ and $t_{3}$ of EH-T1a and EH-T3 respectively. The condition $t_{3} \geq t_{1}$ results in probabilities of zero in the plane $t_{3}<t_{1}$.

As an alternative to numerical integration the distributions can be determined by Monte Carlo simulation, which provides a check for the calculations above. Random samples of Gaussian deviates with the means and standard deviations of the two measured ages for EH-T3 and EH-T1a were kept if $t_{3} \geq t_{1}$ and rejected otherwise. A sample of 10,000 valid pairs for $t_{1}, t_{3}$ gave means and standard deviations for $t_{1}, t_{3}$ that differed from the results above by less than $0.01 \mathrm{ka}$.

The Monte Carlo approach was also used to test the sensitivity of the age of EH-T2 to the choice of a uniform prior. This was done by choosing two alternative priors representing credible extreme cases: triangular distributions with a maximum at EH-T1a and minimum (zero) at EH-T3, and vice versa. The results for the mean age of EH-T2 were $9.0 \pm 1.3 \mathrm{ka}$ and $9.2 \pm 1.3 \mathrm{ka}$ respectively (both $2 \sigma)$; i.e. the means differed from that from the uniform prior by $\pm 0.1 \mathrm{ka}$. 


\section{References}

Campbell, K.W. (1982). Bayesian analysis of extreme earthquake occurrences. Part I. Probabilistic hazard model. Bull. Seism. Soc. Am. 72, 1689-1705.

Congdon P. (2001). Bayesian Statistical Modelling. Wiley Series in Probability and Statistics, John Wiley and Sons, Chichester. 529pp. 


\section{Appendix D}

Shore Platfrom Elevation Data and Plane Fitting Data

All shore platform elevation point locations listed in the following tables are given in New Zealand Map Grid (Geodetic Datum 1949) eastings and northings (meters).

Table D.1. Shore platform plane fitting data

\begin{tabular}{|c|c|c|c|c|c|c|}
\hline \multirow{2}{*}{$\begin{array}{c}\text { Shore Platform } \\
\text { Name (Location) } \\
\text { Age (MIS) }\end{array}$} & \multirow{2}{*}{$\begin{array}{l}\text { Elevation Data } \\
\text { (No. of Points) }\end{array}$} & \multicolumn{2}{|c|}{ Data Point Span } & \multirow[t]{2}{*}{ Strike } & \multirow[t]{2}{*}{ Dip } & \multirow[t]{2}{*}{ Residual } \\
\hline & & $\begin{array}{l}\text { Parallel to coast } \\
(\mathbf{k m})\end{array}$ & $\begin{array}{l}\text { Normal to coast } \\
(\mathbf{k m})\end{array}$ & & & \\
\hline $\begin{array}{c}\text { Ngawi (Cape Palliser) } \\
\text { MIS 5e }\end{array}$ & 10 & 3.4 & 0.7 & 172.9 & 2.9 & 8.3 \\
\hline $\begin{array}{l}\text { Te Humenga Point } \\
\text { MIS 5e }\end{array}$ & 12 & 0.5 & 0.5 & 169.0 & 2.5 & 2.0 \\
\hline $\begin{array}{c}\text { Washpool/Whatarangi } \\
\text { MIS 5a }\end{array}$ & 10 & 1.2 & 0.4 & 205.4 & 1.5 & 0.7 \\
\hline $\begin{array}{l}\text { Whangaimoana } \mathrm{E}-\mathrm{Te} \\
\text { Kopi MIS } 5 \mathrm{c}\end{array}$ & 16 & 2.7 & 0.2 & 210.0 & 0.6 & 0.4 \\
\hline $\begin{array}{c}\text { Whangaimoana E - Lake } \\
\text { Ferry MIS 5c }\end{array}$ & 28 & 1.1 & 0.2 & 156.1 & 0.7 & 0.1 \\
\hline $\begin{array}{l}\text { Wharekauhau } \\
\text { MIS 7a }\end{array}$ & 17 & 1.4 & 0.4 & 132.1 & 0.2 & 3.0 \\
\hline $\begin{array}{l}\text { Baring Head } \\
\text { MIS 5a }\end{array}$ & 12 & 1.7 & 0.2 & 136.1 & 3.0 & 4.7 \\
\hline $\begin{array}{l}\text { Tongue Point E } \\
\text { MIS 5e }\end{array}$ & 7 & 1.1 & $<0.1$ & 122.6 & 7.8 & 28.5 \\
\hline $\begin{array}{l}\text { Tongue Point } \mathrm{W} \\
\text { MIS 5e }\end{array}$ & 3 & 0.4 & $<0.1$ & 291.4 & 8.8 & 0.5 \\
\hline
\end{tabular}

Table D.2 Ngawi (Cape Palliser) Surveyed Elevation Data Points

\begin{tabular}{|c|c|c|}
\hline $\begin{array}{c}\text { Eastings } \\
(\mathrm{x})\end{array}$ & $\begin{array}{c}\text { Northings } \\
(\mathrm{y})\end{array}$ & $\begin{array}{c}\text { Elevation } \\
(\mathrm{z})(\mathrm{m})\end{array}$ \\
\hline 2697097 & 5954168 & 213.15 \\
\hline 2696852 & 5954089 & 195.21 \\
\hline 2696797 & 5954106 & 194.58 \\
\hline 2696747 & 5954139 & 191.46 \\
\hline 2696675 & 5954282 & 193.18 \\
\hline 2696653 & 5954345 & 192.86 \\
\hline 2696697 & 5954383 & 195.35 \\
\hline 2696688 & 5954516 & 193.55 \\
\hline 2696613 & 5954902 & 185.09 \\
\hline 2696155 & 5957395 & 184.53 \\
\hline
\end{tabular}


Table D.3 Te Humenga Point Surveyed Elevation Data Points

\begin{tabular}{|c|c|c|}
\hline $\begin{array}{c}\text { Eastings } \\
(\mathrm{x})\end{array}$ & $\begin{array}{c}\text { Northings } \\
(\mathrm{y})\end{array}$ & $\begin{array}{c}\text { Elevation } \\
(\mathrm{z})(\mathrm{m})\end{array}$ \\
\hline 2694344 & 5962340 & 164.39 \\
\hline 2694112 & 5962402 & 156.48 \\
\hline 2693884 & 5962502 & 148.52 \\
\hline 2693899 & 5962436 & 144.59 \\
\hline 2693899 & 5962436 & 144.08 \\
\hline 2693833 & 5962545 & 145.73 \\
\hline 2693823 & 5962562 & 145.65 \\
\hline 2693819 & 5962565 & 144.93 \\
\hline 2693810 & 5962580 & 145.57 \\
\hline 2693732 & 5962694 & 139.92 \\
\hline 2693978 & 5962643 & 152.31 \\
\hline 2694474 & 5962591 & 171.81 \\
\hline
\end{tabular}

Table D.4 Washpool/ Whatarangi Surveyed Elevation Data Points

\begin{tabular}{|c|c|c|}
\hline $\begin{array}{c}\text { Eastings } \\
(\mathrm{x})\end{array}$ & $\begin{array}{c}\text { Northings } \\
(\mathrm{y})\end{array}$ & $\begin{array}{c}\text { Elevation } \\
(\mathrm{z})(\mathrm{m})\end{array}$ \\
\hline 2694771 & 5966964 & 79.93 \\
\hline 2694691 & 5967012 & 76.88 \\
\hline 2694699 & 5966848 & 78.58 \\
\hline 2694919 & 5966636 & 87.33 \\
\hline 2694818 & 5966618 & 83.78 \\
\hline 2694750 & 5966455 & 86.52 \\
\hline 2694669 & 5966514 & 81.52 \\
\hline 2694568 & 5966367 & 82.02 \\
\hline 2694663 & 5967515 & 72.05 \\
\hline 2694703 & 5967427 & 73.75 \\
\hline
\end{tabular}


Table D.5 Whangaimoana East - Te Kopi Surveyed Elevation Data Points

\begin{tabular}{|c|c|c|}
\hline $\begin{array}{c}\text { Eastings } \\
(\mathrm{x})\end{array}$ & $\begin{array}{c}\text { Northings } \\
(\mathrm{y})\end{array}$ & $\begin{array}{c}\text { Elevation } \\
(\mathrm{z})(\mathrm{m})\end{array}$ \\
\hline 2695111 & 5972961 & 80.90 \\
\hline 2695163 & 5973001 & 81.00 \\
\hline 2695175 & 5973011 & 81.20 \\
\hline 2694997 & 5973144 & 78.50 \\
\hline 2694997 & 5973146 & 79.90 \\
\hline 2695025 & 5973176 & 77.60 \\
\hline 2695127 & 5973154 & 80.70 \\
\hline 2695138 & 5973175 & 80.30 \\
\hline 2695127 & 5973153 & 79.70 \\
\hline 2694724 & 5973392 & 76.60 \\
\hline 2694726 & 5973403 & 75.10 \\
\hline 2694716 & 5973385 & 75.20 \\
\hline 2694102 & 5973898 & 66.70 \\
\hline 2694108 & 5973881 & 67.10 \\
\hline 2693326 & 5974404 & 57.50 \\
\hline 2693326 & 5974404 & 57.30 \\
\hline
\end{tabular}


Table D.6 Whangaimoana West - Lake Ferry Surveyed Elevation Data Points

\begin{tabular}{|c|c|c|}
\hline $\begin{array}{l}\text { Eastings } \\
(\mathrm{x})\end{array}$ & $\begin{array}{c}\text { Northings } \\
\text { (y) }\end{array}$ & $\begin{array}{c}\text { Elevation } \\
(\mathrm{z})(\mathrm{m})\end{array}$ \\
\hline 2690907 & 5975770 & 40.70 \\
\hline 2690903 & 5975757 & 40.80 \\
\hline 2690900 & 5975744 & 40.90 \\
\hline 2690891 & 5975729 & 41.10 \\
\hline 2690734 & 5975829 & 40.20 \\
\hline 2690761 & 5975830 & 40.20 \\
\hline 2690681 & 5975966 & 39.30 \\
\hline 2690666 & 5975958 & 39.10 \\
\hline 2690651 & 5975940 & 39.20 \\
\hline 2690628 & 5975927 & 39.30 \\
\hline 2690611 & 5975936 & 39.00 \\
\hline 2690576 & 5975941 & 39.00 \\
\hline 2690561 & 5975966 & 38.40 \\
\hline 2690553 & 5975978 & 39.00 \\
\hline 2690463 & 5975981 & 37.70 \\
\hline 2690480 & 5976009 & 38.50 \\
\hline 2690506 & 5976040 & 38.80 \\
\hline 2690543 & 5976051 & 39.00 \\
\hline 2690572 & 5976089 & 39.60 \\
\hline 2690595 & 5976034 & 39.10 \\
\hline 2690237 & 5976127 & 35.40 \\
\hline 2690233 & 5976122 & 35.70 \\
\hline 2690230 & 5976116 & 35.80 \\
\hline 2690062 & 5976223 & 33.90 \\
\hline 2690064 & 5976209 & 34.10 \\
\hline 2690068 & 5976226 & 34.10 \\
\hline 2689919 & 5976335 & 33.10 \\
\hline 2689918 & 5976331 & 33.40 \\
\hline
\end{tabular}


Table D.7 Wharekauhau Surveyed Elevation Data Points

\begin{tabular}{|c|c|c|}
\hline $\begin{array}{c}\text { Eastings } \\
(\mathrm{x})\end{array}$ & $\begin{array}{c}\text { Northings } \\
(\mathrm{y})\end{array}$ & $\begin{array}{c}\text { Elevation } \\
(\mathrm{z})(\mathrm{m})\end{array}$ \\
\hline 2682489 & 5979289 & 9.43 \\
\hline 2682488 & 5979284 & 9.55 \\
\hline 2683270 & 5979093 & 15.22 \\
\hline 2683296 & 5979181 & 15.22 \\
\hline 2683282 & 5979172 & 15.22 \\
\hline 2683269 & 5979132 & 15.22 \\
\hline 2683264 & 5979118 & 15.22 \\
\hline 2683533 & 5978967 & 15.22 \\
\hline 2683585 & 5978993 & 15.22 \\
\hline 2683585 & 5978986 & 13.61 \\
\hline 2683570 & 5978962 & 11.73 \\
\hline 2683573 & 5978970 & 11.73 \\
\hline 2683574 & 5978974 & 11.73 \\
\hline 2683839 & 5979303 & 14.53 \\
\hline 2683840 & 5979288 & 14.49 \\
\hline 2683841 & 5979297 & 14.39 \\
\hline 2682466 & 5979387 & 14.39 \\
\hline
\end{tabular}

Table D.8 Baring Head Surveyed Elevation Data Points

\begin{tabular}{|c|c|c|}
\hline $\begin{array}{c}\text { Eastings } \\
(\mathrm{x})\end{array}$ & $\begin{array}{c}\text { Northings } \\
(\mathrm{y})\end{array}$ & $\begin{array}{c}\text { Elevation } \\
(\mathrm{z})(\mathrm{m})\end{array}$ \\
\hline 2667181 & 5975960 & 86.88 \\
\hline 2667205 & 5975946 & 87.03 \\
\hline 2667267 & 5975873 & 91.23 \\
\hline 2667074 & 5975836 & 80.21 \\
\hline 2667013 & 5975859 & 77.77 \\
\hline 2666892 & 5975915 & 75.17 \\
\hline 2666861 & 5975910 & 73.25 \\
\hline 2666770 & 5975961 & 70.58 \\
\hline 2666675 & 5975938 & 66.22 \\
\hline 2668307 & 5975504 & 108.51 \\
\hline 2668016 & 5975573 & 107.36 \\
\hline 2668023 & 5975571 & 107.51 \\
\hline
\end{tabular}


Table D.9 Tongue Point East Surveyed Elevation Data Points

\begin{tabular}{|c|c|c|}
\hline $\begin{array}{c}\text { Eastings } \\
(\mathrm{x})\end{array}$ & $\begin{array}{c}\text { Northings } \\
(\mathrm{y})\end{array}$ & $\begin{array}{c}\text { Elevation } \\
(\mathrm{z})(\mathrm{m})\end{array}$ \\
\hline 2649740 & 5983821 & 47.88 \\
\hline 2649682 & 5983856 & 47.91 \\
\hline 2649546 & 5983917 & 44.96 \\
\hline 2649496 & 5983948 & 49.56 \\
\hline 2648782 & 5984265 & 29.15 \\
\hline 2648767 & 5984280 & 28.62 \\
\hline 2648733 & 5984282 & 27.02 \\
\hline
\end{tabular}

Table D.10 Tongue Point West Surveyed Elevation Data Points

\begin{tabular}{|c|c|c|}
\hline $\begin{array}{c}\text { Eastings } \\
(\mathrm{x})\end{array}$ & $\begin{array}{c}\text { Northings } \\
(\mathrm{y})\end{array}$ & $\begin{array}{c}\text { Elevation } \\
(\mathrm{z})(\mathrm{m})\end{array}$ \\
\hline 2648457 & 5985054 & 63.89 \\
\hline 2648248 & 5985072 & 73.10 \\
\hline 2648062 & 5985154 & 71.88 \\
\hline
\end{tabular}


Appendix E

Stratigraphic Logs of Marine Terraces
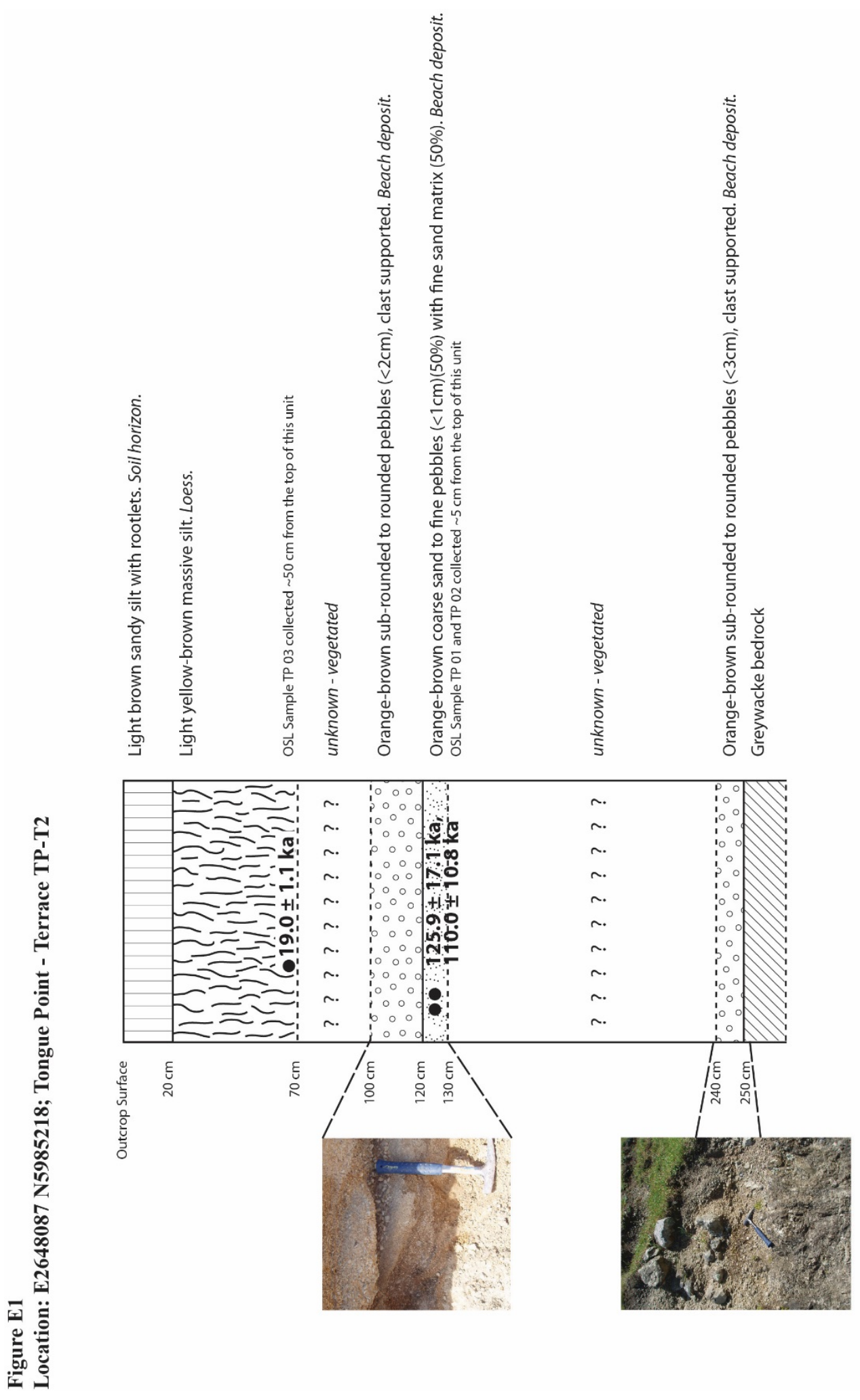


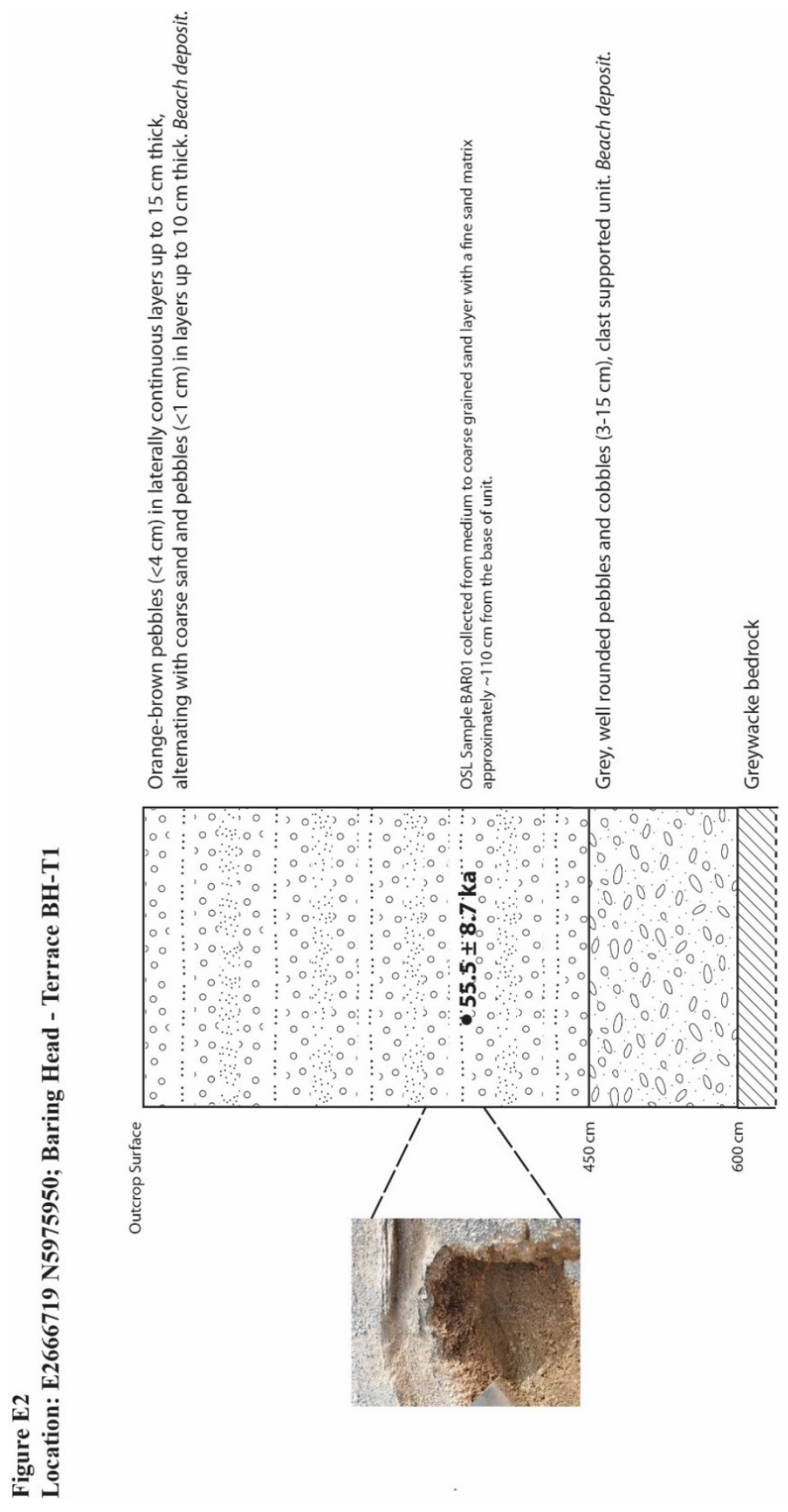




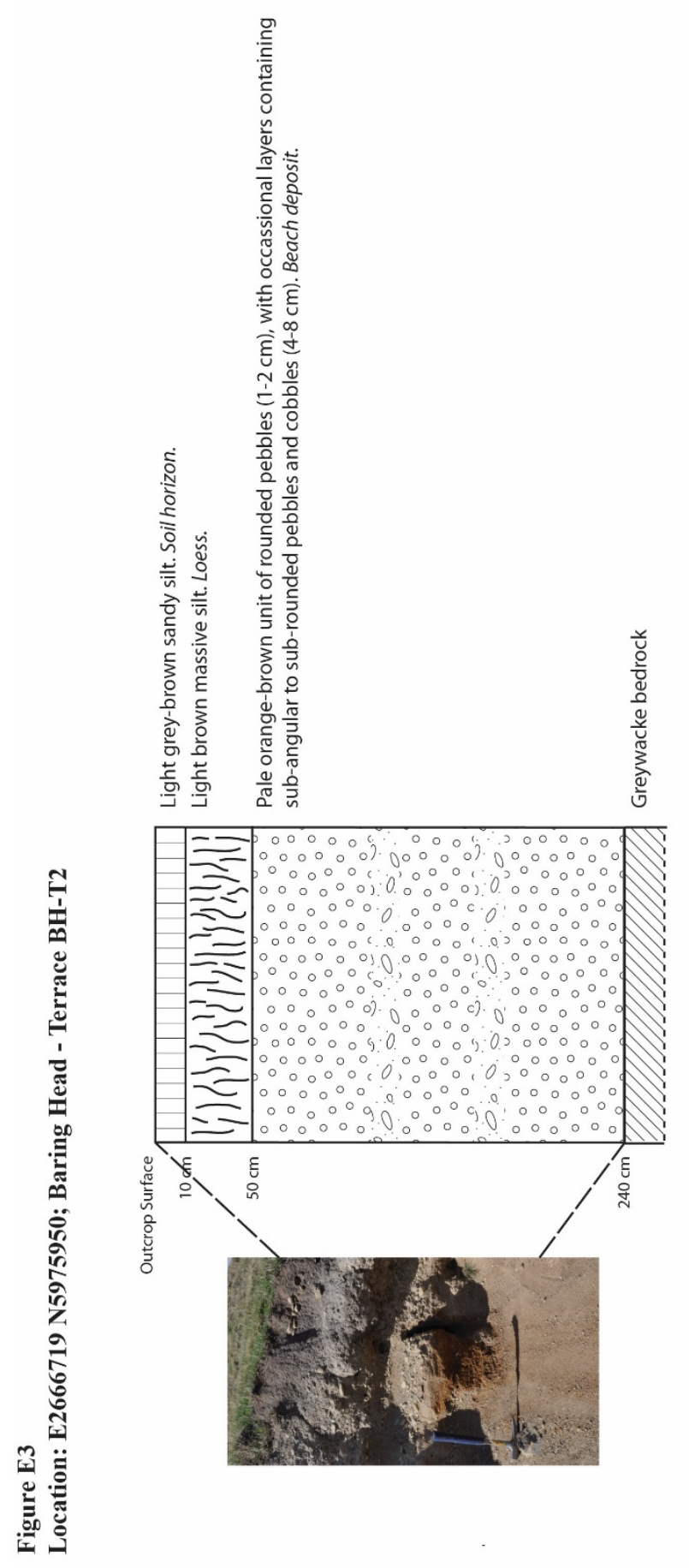




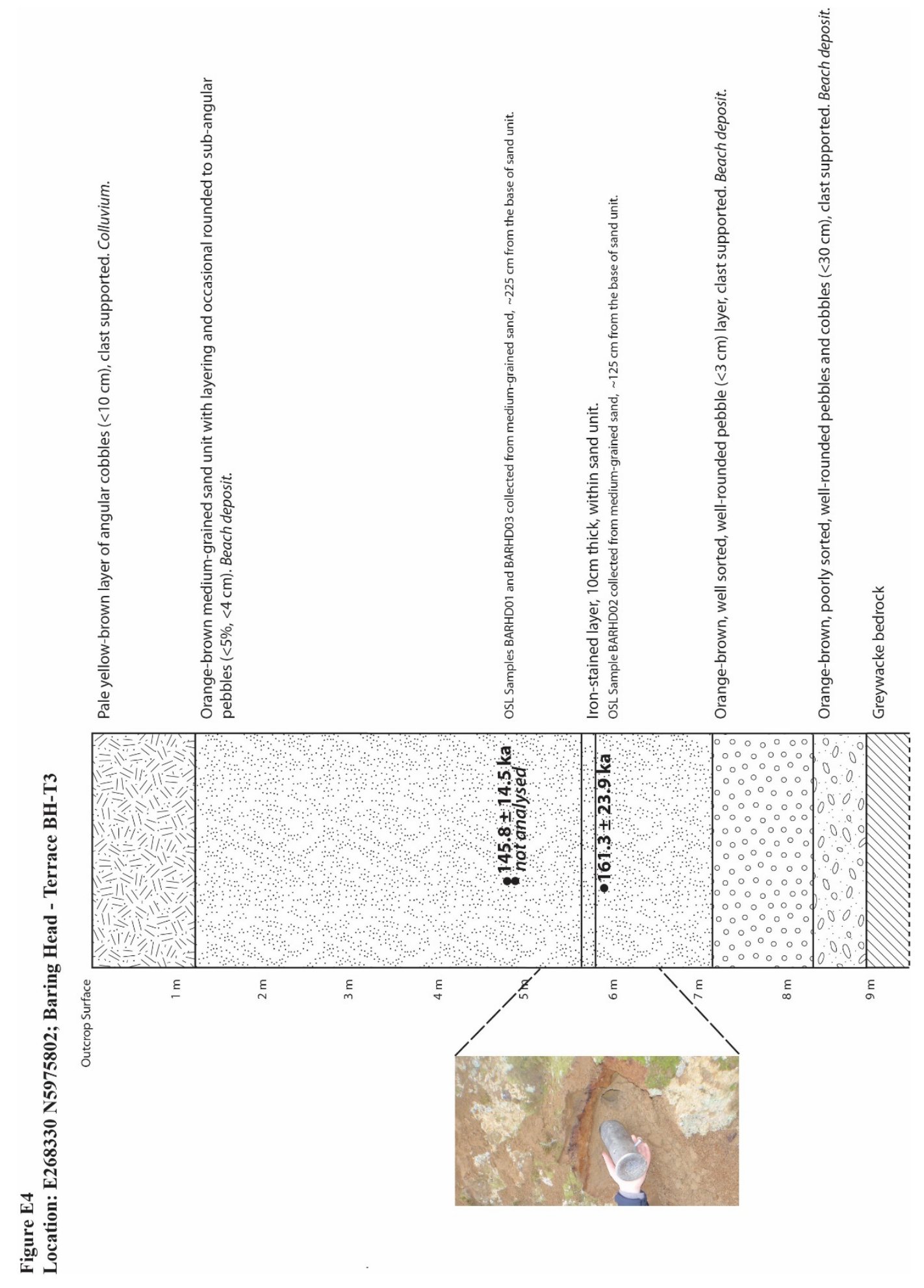




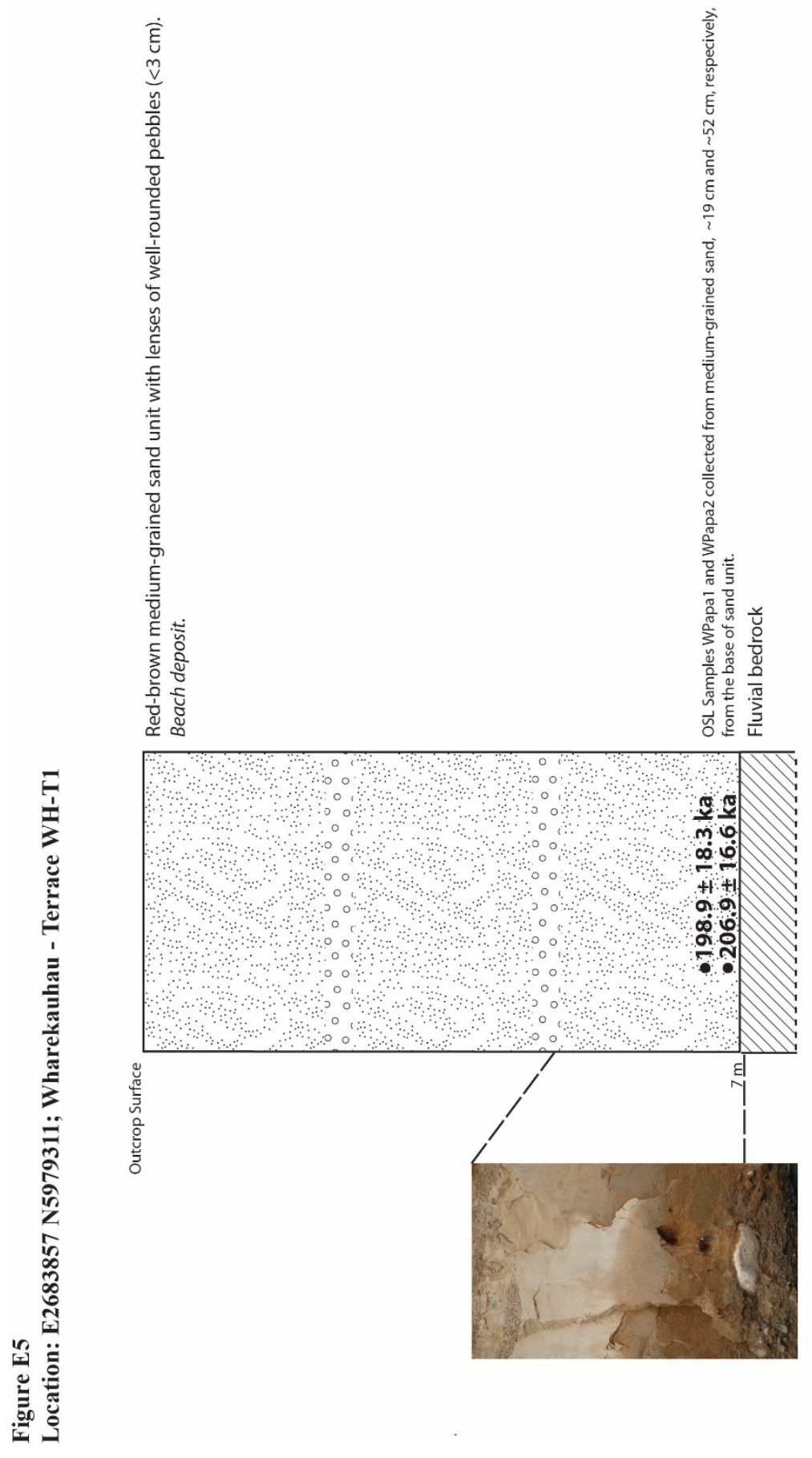




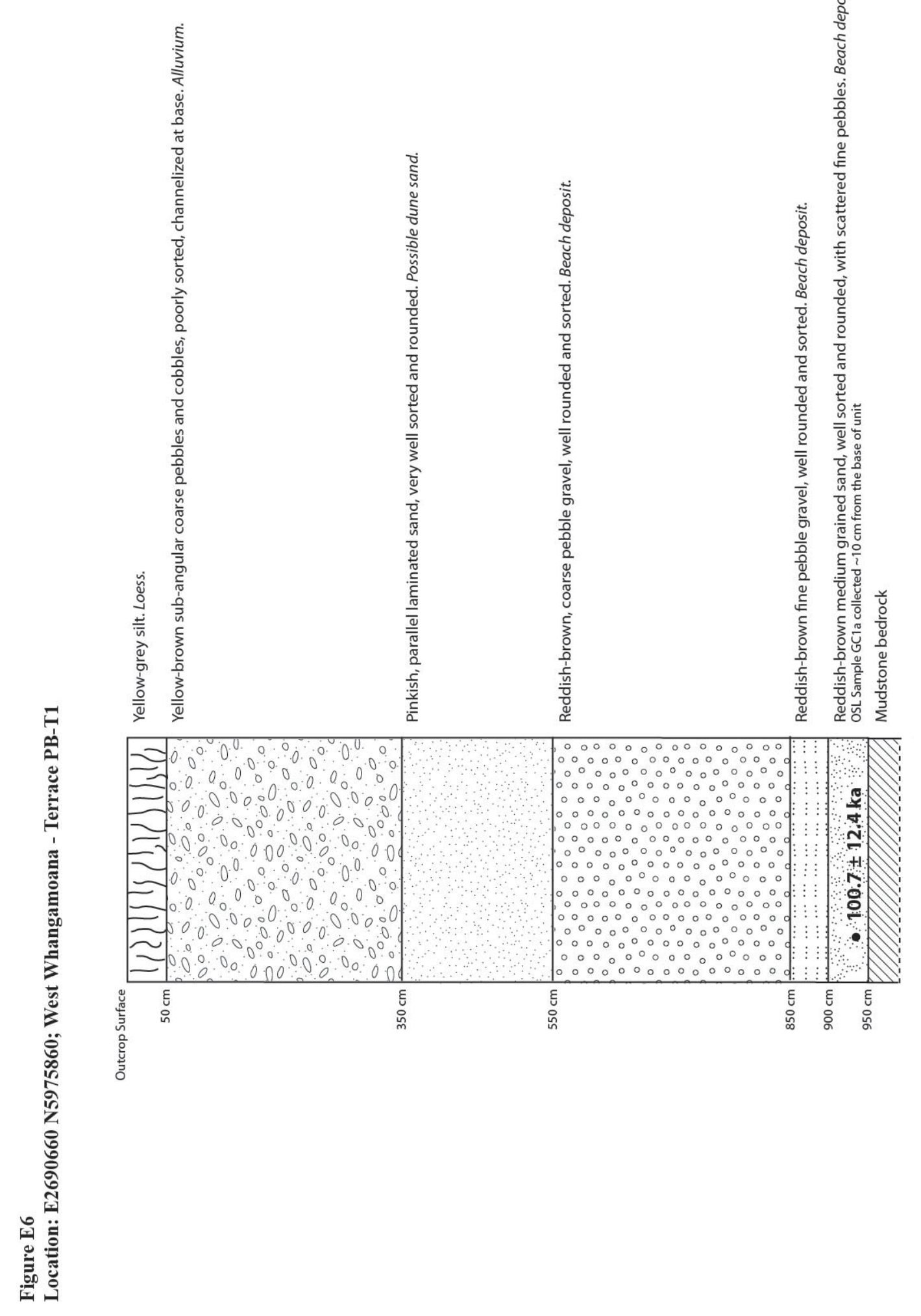




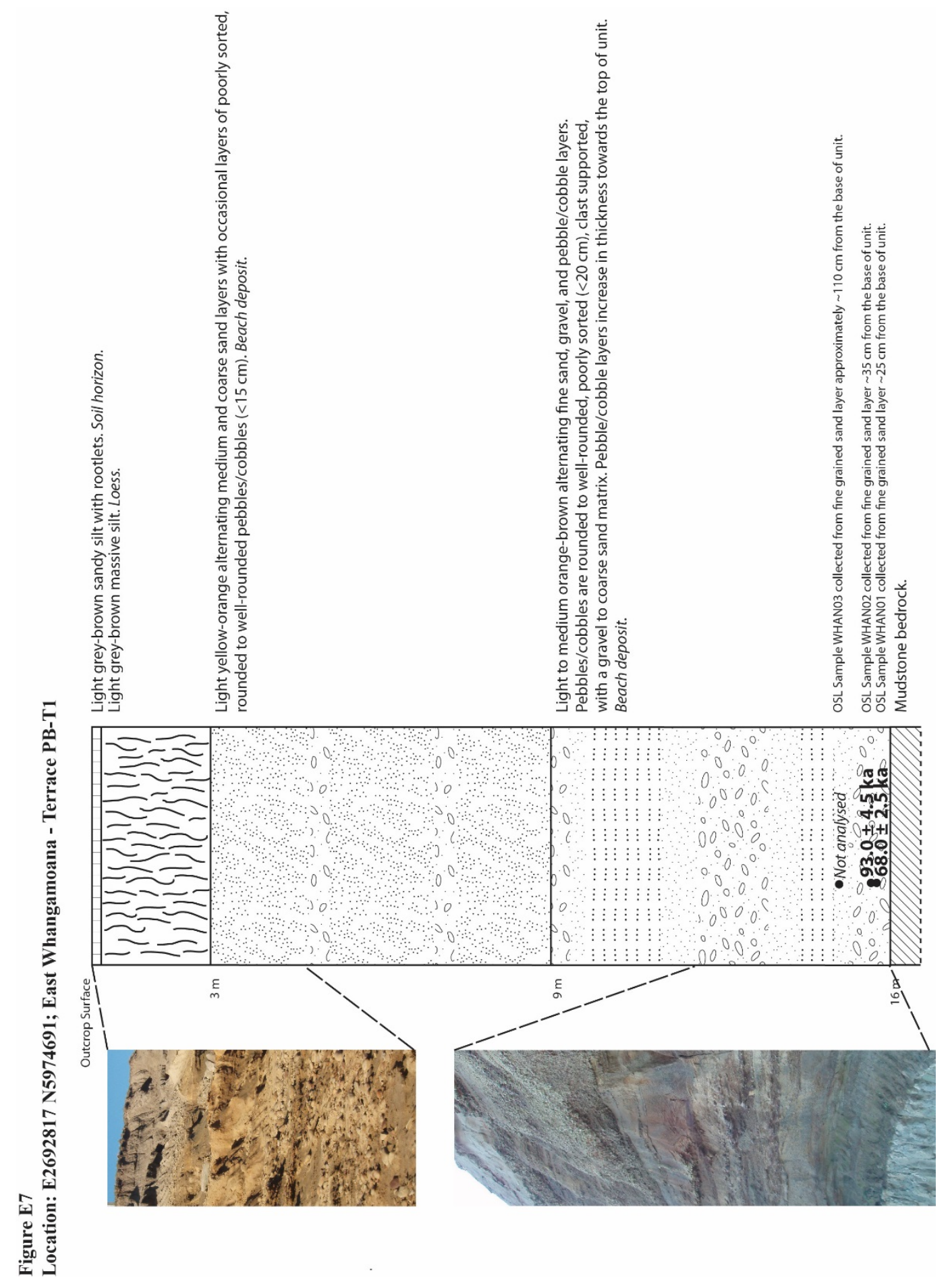




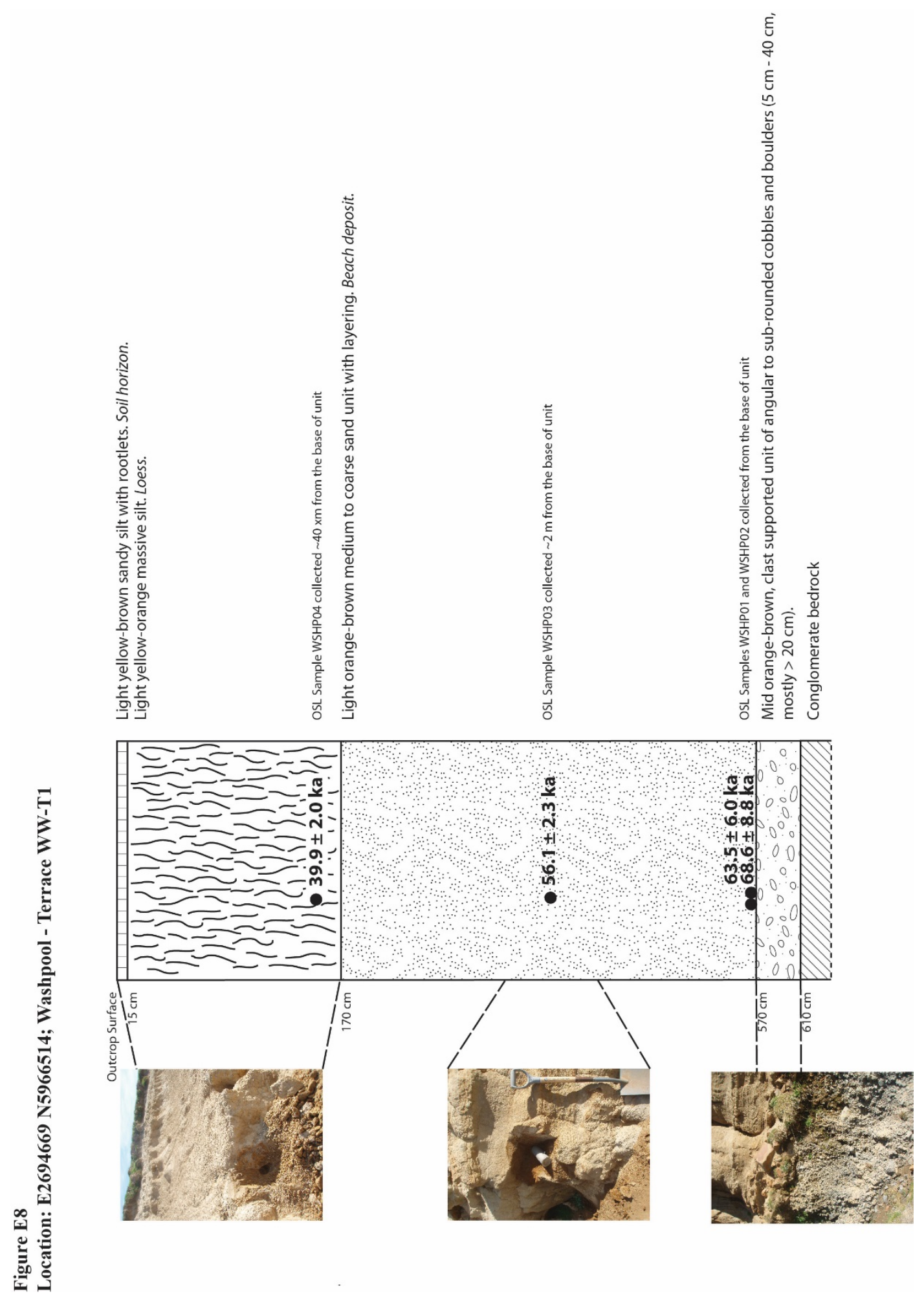




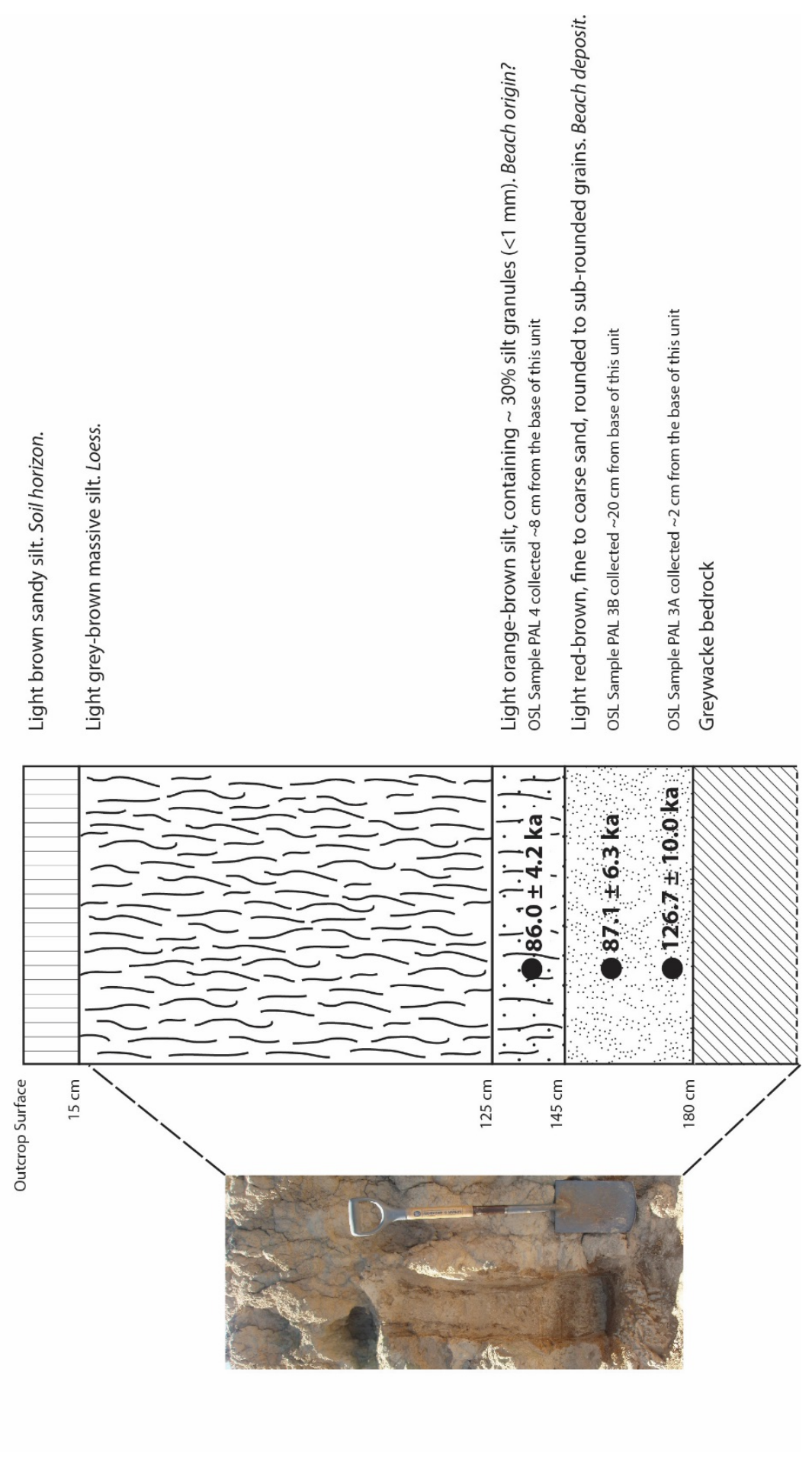




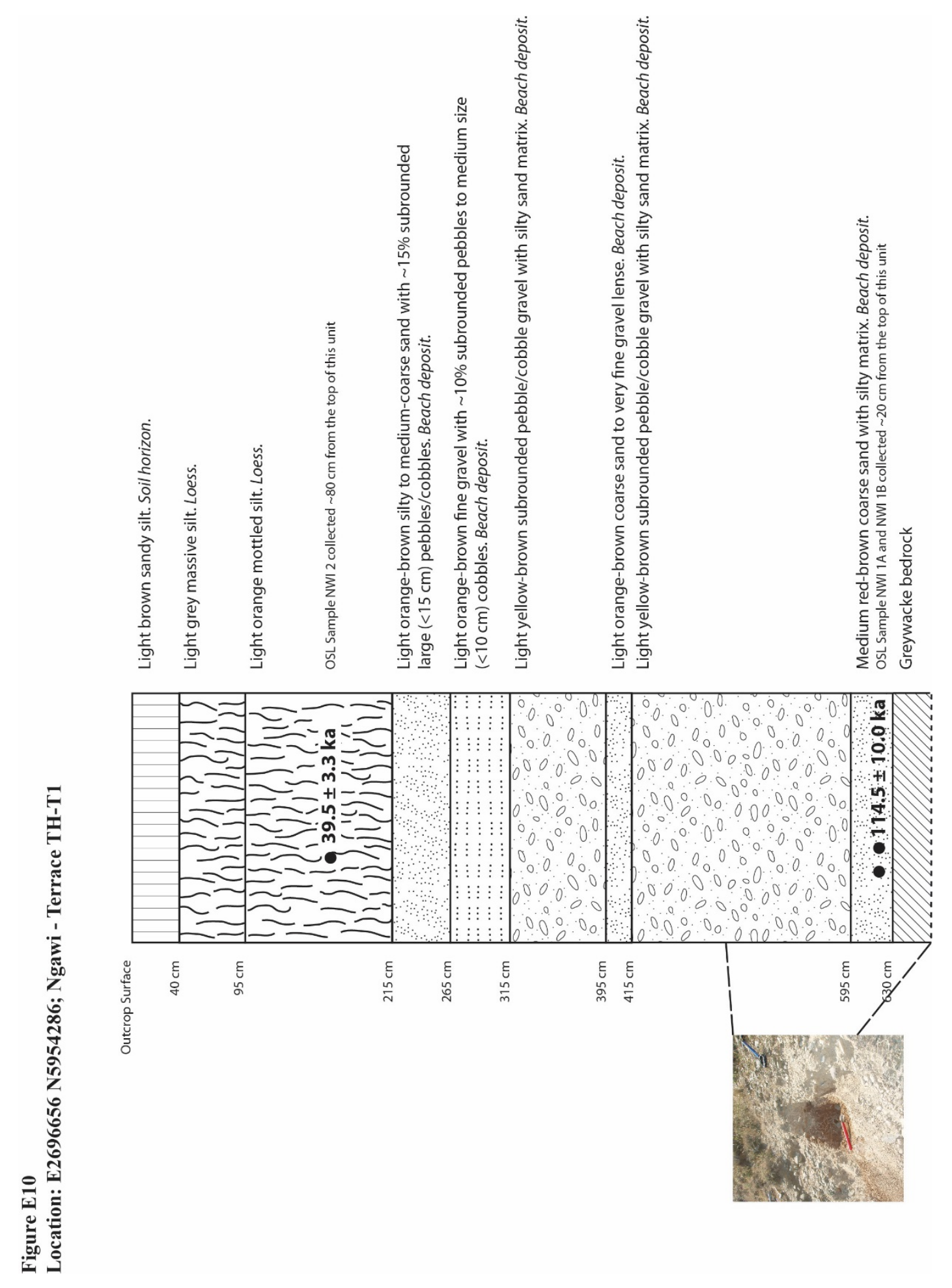

